\title{
LA-UR-17-21060
}

Approved for public release; distribution is unlimited.

Title: $\quad$ Los Alamos Climatology 2016 Update

Author(s): $\quad$ Bruggeman, David Alan

Intended for: Report

Issued: 
Disclaimer:

Los Alamos National Laboratory, an affirmative action/equal opportunity employer, is operated by the Los Alamos National Security, LLC for the National Nuclear Security Administration of the U.S. Department of Energy under contract DE-AC52-06NA25396. By approving this article, the publisher recognizes that the U.S. Government retains nonexclusive, royalty-free license to publish or reproduce the published form of this contribution, or to allow others to do so, for U.S. Government purposes. Los Alamos National Laboratory requests that the publisher identify this article as work performed under the auspices of the U.S. Department of Energy. Los Alamos National Laboratory strongly supports academic freedom and a researcher's right to publish; as an institution, however, the Laboratory does not endorse the viewpoint of a publication or guarantee its technical correctness. 
LA-UR-17-XXXXX

February 2017

\section{Los Alamos Climatology 2016 Update}




\section{Authors: Jean Dewart, David Bruggeman, and Vince Carretti, EPC-CP}

Los Alamos National Laboratory, an affirmative action/equal opportunity employer, is operated by the Los Alamos National Security, LLC, for the National Nuclear Security Administration of the U.S. Department of Energy under contract DE-AC52-06NA25396. By acceptance of this article, the publisher recognizes that the U.S. Government retains a nonexclusive, royalty-free license to publish or reproduce the published form of this contribution, or to allow others to do so, for U.S. Government purposes. Los Alamos National Laboratory requests that the publisher identify this article as work performed under the auspices of the U.S. Department of Energy. Los Alamos National Laboratory strongly supports academic freedom and a researcher's right to publish; as an institution, however, the Laboratory does not endorse the viewpoint of a publication or guarantee its technical correctness. 


\section{CONTENTS}

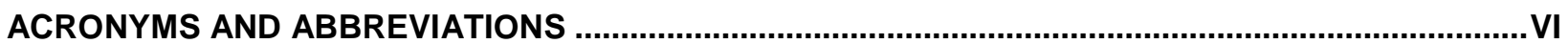

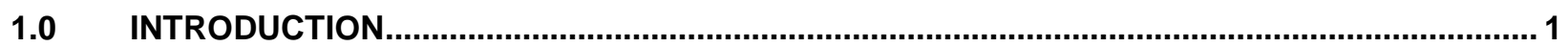

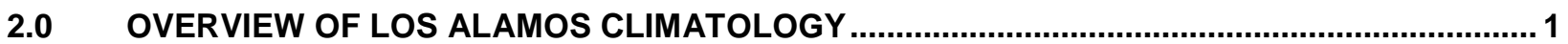

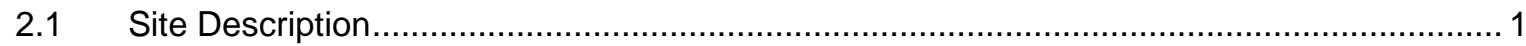

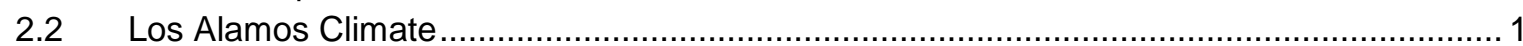

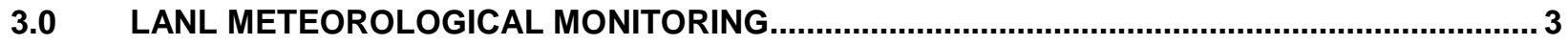

4.0 TEMPERATURE

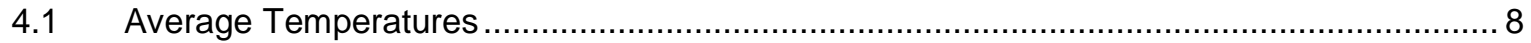

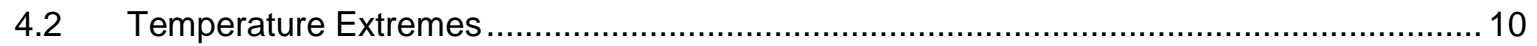

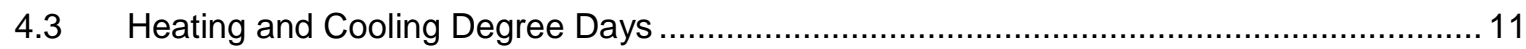

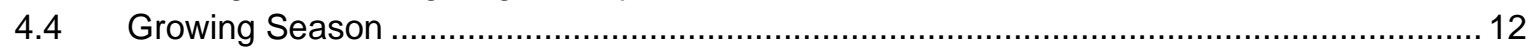

4.5 Temperature Variation Across the Laboratory ......................................................... 13

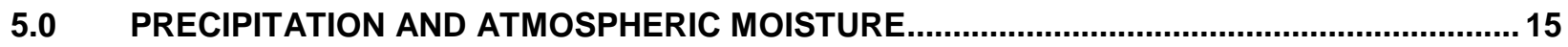

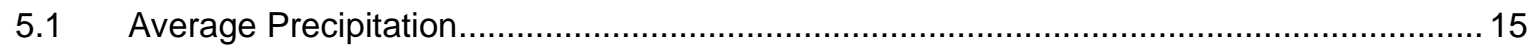

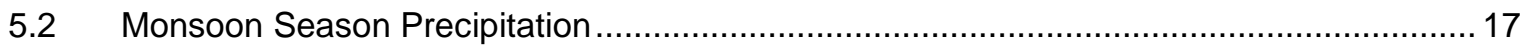

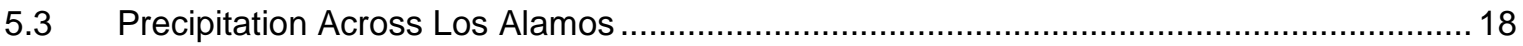

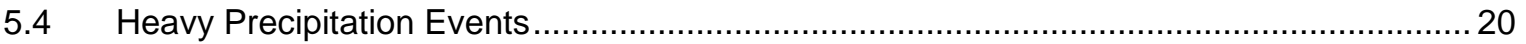

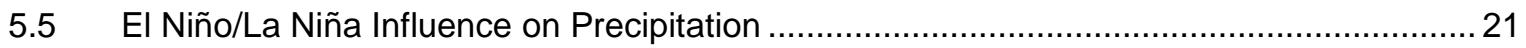

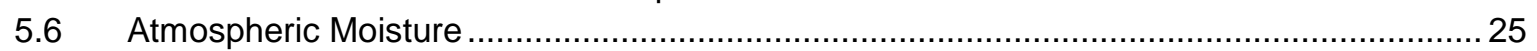

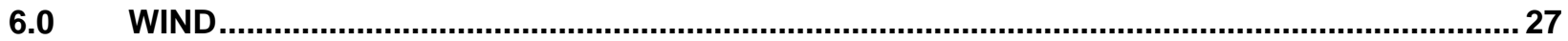

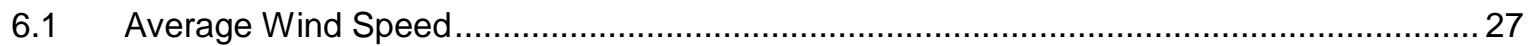

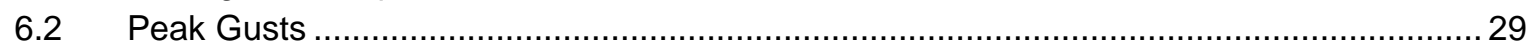

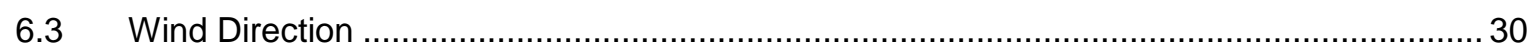

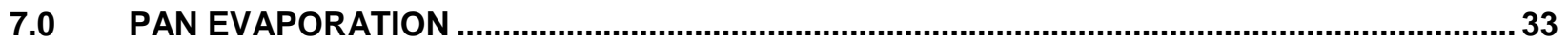

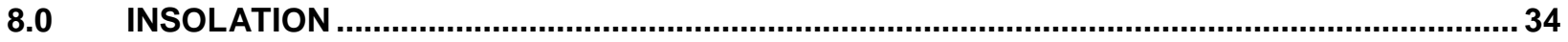

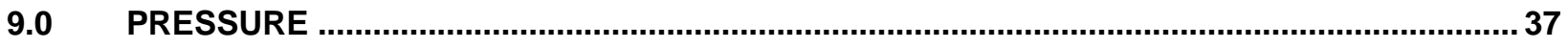

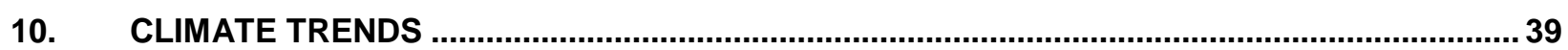

10.1 Temperature

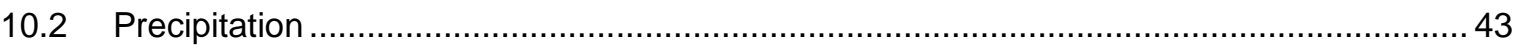

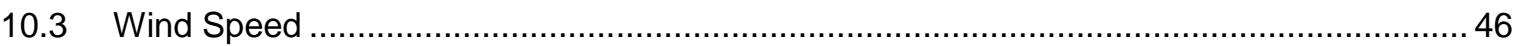

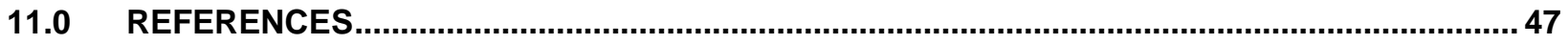

APPENDIX Monthly Average Temperatures and Precipitation for Los Alamos and White Rock ... 49

\section{Figures}

Figure 2-2: $\quad$ Topography of Los Alamos and vicinity. Current meteorology monitoring stations are shown along with the Los Alamos and White Rock residential areas. ............................. 4

Figure 3-1: $\quad$ Location of meteorological monitoring stations at Los Alamos. TA-41 and Pajarito Mountain are no longer operational. ......................................................................... 5

Figure 3-2: $\quad$ Canyon locations of meteorology towers. ............................................................ 7

Figure 4-1: $\quad$ Monthly average temperatures for Los Alamos and White Rock (1981-2010)................9 
Figure 4-2: Monthly average heating and cooling degree days for Los Alamos and White Rock

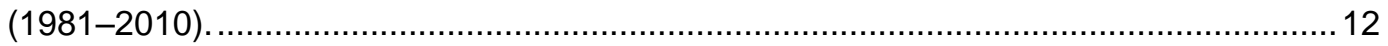

Figure 4-3: $\quad$ Monthly average maximum temperatures across Los Alamos County. .......................... 14

Figure 4-4: $\quad$ Monthly average minimum temperatures across Los Alamos County. ......................... 15

Figure 5-1: $\quad$ Monthly average precipitation for Los Alamos and White Rock (1981-2010)................. 16

Figure 5-2: $\quad$ Monthly average snowfall in Los Alamos (1981-2010)............................................... 17

Figure 5-3: Schematic of surface wind patterns during the North American Monsoon (Crimmins

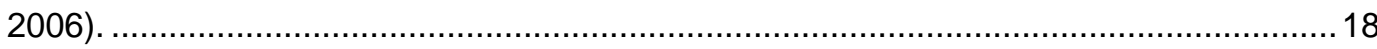

Figure 5-4: Monthly average precipitation across the Laboratory (1994-2013). NCOM August and September averages are low due to missing data during 2005, but the available data are left in the figure for context. ................................................................................. 19

Figure 5-5: Annual average monsoon season precipitation (1994-2013). A significant amount of data is missing for NCOM for August-September 2005; this point was eliminated from the graph.

Figure 5-6: Winter atmospheric circulation patterns during El Niño and La Niña winter events

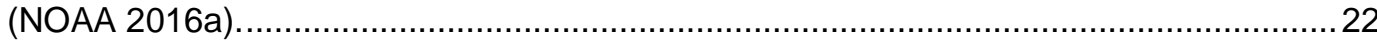

Figure 5-7: $\quad$ Pacific sea surface temperature anomalies (1981-2016) and major Los Alamos

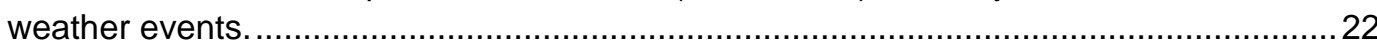

Figure 5-8: Los Alamos precipitation during El Niño winters. The year represents the year of the end of the winter (e.g., 2016 is the winter of 2015-2016)

Figure 5-9: Los Alamos precipitation during La Niña years. The year represents the year of the end of the winter (e.g., 2016 is the winter of 2015-2016) ............................................. 24

Figure 5-10: Los Alamos precipitation during El Niño/La Niña neutral years. The year represents the year of the end of the winter (e.g., 2016 is the winter of 2015-2016).......................24

Figure 5-11: $\quad$ Monthly average dew point temperatures (1994-2013) . ..............................................26

Figure 5-12: Monthly average relative humidity (1994-2013)........................................................2 27

Figure 6-1: $\quad$ Monthly average wind speeds at 12 meters AGL for mesa-top and canyon towers. PJMT is measured at 36 meters AGL......................................................................... 29

Figure 6-2: $\quad$ Monthly average peak wind gusts at 12 meters AGL. PJMT is measured at 36 meters

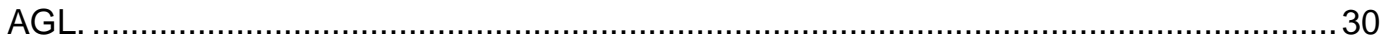

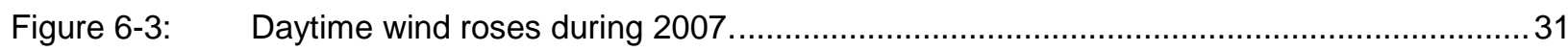

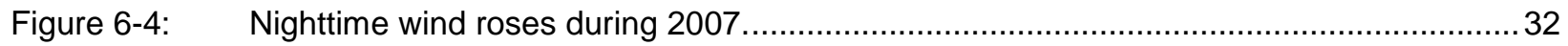

Figure 7-1: $\quad$ Monthly average pan evaporation at Abiquiu Dam and El Vado Dam (1981-2010)........33

Figure 8-1: $\quad$ Conceptual diagram of incoming solar radiation and outgoing longwave (infrared)

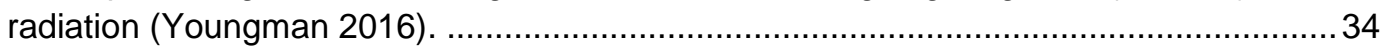

Figure 8-2: $\quad$ Monthly average incoming solar radiation (1994-2013) ............................................. 35

Figure 8-3: $\quad$ Monthly average surface radiation energy balance at TA-6 (1994-2013)...................... 36

Figure 8-4: Monthly average surface radiation energy balance at TA-54 (1994-2013).................... 36

Figure 9-1: $\quad$ Monthly average maximum and minimum pressure at TA-6 and TA-54 (1994-2013).....38

Figure 9-2: $\quad$ Hourly average pressure at TA-6 and TA-54 (minus $25 \mathrm{mb}$ ) during 2013...................... 39

Figure 10-1: Temperature history for Los Alamos (1924-2015). .................................................... 40

Figure 10-2: Decadal average temperatures and two times the standard error for Los Alamos (1960-2015)...... 
Figure 10-3: Annual average summertime temperatures for Los Alamos (1990-2015).................... 41

Figure 10-4: $\quad$ Number of days per year with maximum temperature above $90^{\circ} \mathrm{F}$ for Los Alamos......... 42

Figure 10-5: $\quad$ Number of days per year with minimum temperature less than $0^{\circ} \mathrm{F}$ for Los Alamos. ...... 42

Figure 10-6: Precipitation history for Los Alamos (1924-2015)..................................................43

Figure 10-7: $\quad$ Annual snowfall (July 1-June 1) for Los Alamos (1951-2015). ..................................44

Figure 10-8: $\quad$ First and last day of snow for Los Alamos (1981-2016)........................................... 44

Figure 10-9: $\quad$ Annual monsoon precipitation for Los Alamos (1951-2015)....................................... 45

Figure 10-10: Number of days per year with measured rainfall ( $>0.5$ inches) for Los Alamos (1951-

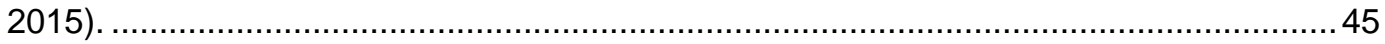

Figure 10-11: Annual average wind speed at 12 meters AGL at TA-6 (1994-2015).......................... 46

\section{Tables}

Table 3-1: Meteorological Monitoring Stations and Summary of Meteorological Measurements at

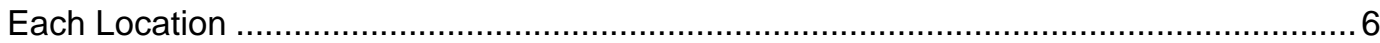

Table 4-1: $\quad$ Monthly Average Temperatures for Los Alamos and White Rock in ${ }^{\circ} \mathrm{F}$ (1981-2010) ....... 8

Table 4-2: $\quad$ Monthly Extreme Temperatures for Los Alamos (1910-2016) .......................................10

Table 4-3: $\quad$ Monthly Extreme Temperatures for White Rock (1964-2016) ......................................10

Table 4-4: $\quad$ Monthly Average Heating and Cooling Degree Days for Los Alamos and White Rock

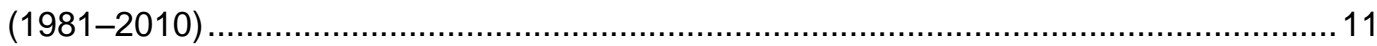

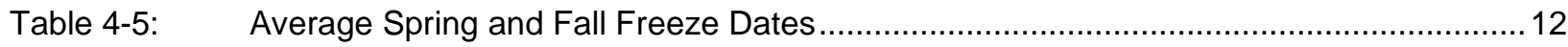

Table 4-6: Record Dates of Last Freeze in the Spring and Earliest Freeze in the Fall....................13

Table 4-7: $\quad$ Monthly Average Maximum Temperatures in ${ }^{\circ} \mathrm{F}$...................................................... 13

Table 4-8: $\quad$ Monthly Average Minimum Temperatures in ${ }^{\circ} \mathrm{F}$................................................... 14

Table 5-1: $\quad$ Monthly Average Precipitation and Snowfall in Inches for Los Alamos and White Rock

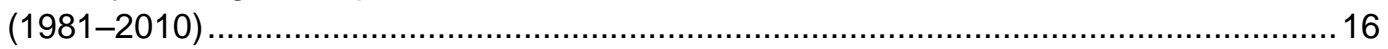

Table 5-2: $\quad$ Monthly Average Precipitation Across the Laboratory in Inches (1994-2013)................ 19

Table 5-3: $\quad$ Monthly Average Number of Days with Precipitation Greater Than 0.5 Inches ..............20

Table 5-4: $\quad$ Top 10 Greatest 1-day Rainfall Events for Los Alamos and White Rock .......................21

Table 5-5: $\quad$ Monthly Average Dew Point Temperatures in ${ }^{\circ} \mathrm{F}(1994-2013)$...................................... 25

Table 5-6: Monthly Average Relative Humidity in Percent (1994-2013) .......................................26

Table 6-1: $\quad$ Monthly Average Wind Speeds at 12 meters AGL in mph ..........................................28

Table 6-2: $\quad$ Monthly Average Peak Wind Gusts at 12 meters AGL in mph .....................................29

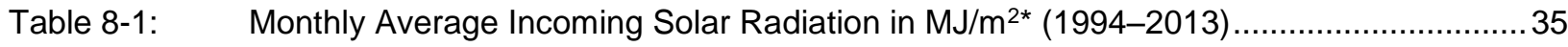

Table 9-1: $\quad$ Monthly Average Pressure at TA-6 and TA-54 in mb (1994-2013) ...............................37 


\section{ACRONYMS AND ABBREVIATIONS}

AGL above ground level

ENSO El Niño Southern Oscillation

KLAM Los Alamos County Airport

LANL Los Alamos National Laboratory

$\mathrm{mb} \quad$ millibar

MDCN Mortandad Canyon

mph miles per hour

MSL above mean sea level

NCOM North Community

PDO Pacific Decadal Oscillation

PJMT Pajarito Mountain

SODAR Sound detection and ranging

TA Technical Area 


\section{$1.0 \quad$ INTRODUCTION}

The Los Alamos National Laboratory (LANL or the Laboratory) operates a meteorology monitoring network to support LANL emergency response, engineering designs, environmental compliance, environmental assessments, safety evaluations, weather forecasting, environmental monitoring, research programs, and environmental restoration. Weather data has been collected in Los Alamos since 1910. Bowen (1990) provided climate statistics (temperature and precipitation) for the 19611990 averaging period, and included other analyses (e.g., wind and relative humidity) based on the available station locations and time periods. This report provides an update to the 1990 publication Los Alamos Climatology (Bowen 1990).

Since 1990, the LANL meteorological monitoring network has evolved through the retirement and installation of monitoring locations. The most significant changes include:

- Installation of 46-meter (150-foot) towers at Technical Area (TA) 53 and TA-54,

- Installation of a 10-meter (33-foot) tower in Mortandad Canyon (TA-5 MDCN),

- Retirement of the TA-41 tower, and 10-meter towers at Area G and East Gate, and

- Relocation of the 92-meter (300-foot) tower from TA-50 to TA-6.

Climate statistics for this report have been updated to 1981-2010, and other parameters (e.g., wind, relative humidity) have been updated to include 20 years of data when available. In addition, this document presents evaluations of climate trends measured at LANL.

\subsection{OVERVIEW OF LOS ALAMOS CLIMATOLOGY}

\subsection{Site Description}

LANL is located in north central New Mexico, approximately 60 miles north-northeast of Albuquerque and 25 miles northwest of Santa Fe (Figure 2-1). The 39-square-mile Laboratory is situated on the Pajarito Plateau, which consists of a series of fingerlike mesas separated by deep eastto-west oriented canyons cut by streams. Mesa tops range in elevation from approximately 7800 feet above mean sea level (MSL) on the flanks of the Jemez Mountains to approximately 6200 feet MSL at the edge of White Rock Canyon. The Laboratory is bounded on the north by the Los Alamos townsite; on the west by the Santa Fe National Forest; on the south by Bandelier National Monument; and to the east by San Ildefonso Pueblo, the community of White Rock, and the Rio Grande.

\subsection{Los Alamos Climate}

The World Meteorological Organization defines climate normal as the arithmetic average of a climate element (e.g., temperature) over a 30-year period (WMO 1989). A 30-year period is long enough to filter out any interannual variation or anomalies, but short enough to be able to show longer climatic trends. The 30 -year climate normals are updated every 10 years. The current climate normal data presented in this report are calculated from January 1, 1981 to December 31, 2010. 


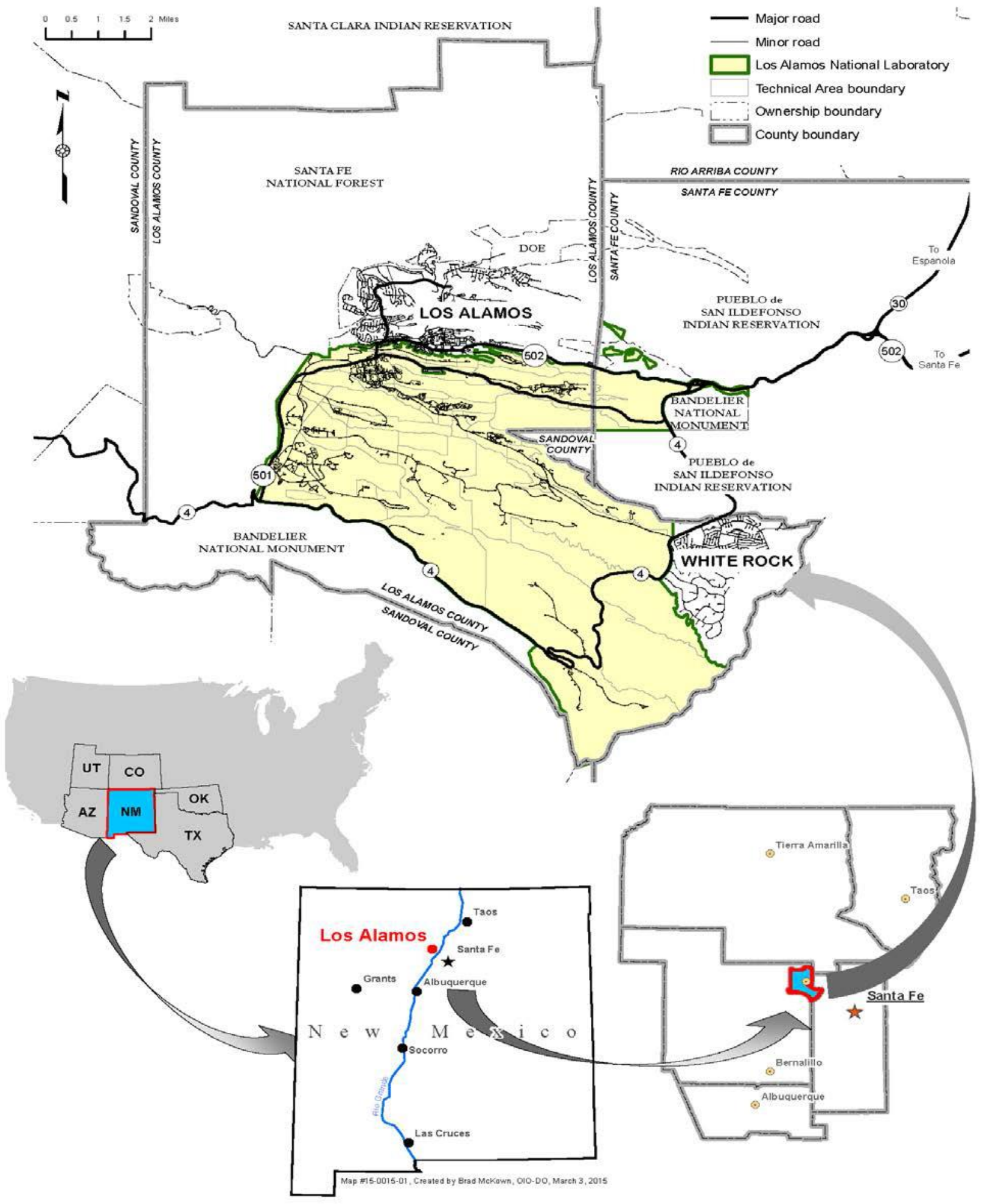

Figure 2-1: Regional location of Los Alamos. 
The climate of Los Alamos is driven by our southern midlatitude location (approximately $36^{\circ} \mathrm{N}$ ), distance from the Pacific Ocean and Gulf of Mexico (approximately 700-800 miles), and the altitude (6200-7800 feet MSL across the Laboratory). During the fall, winter, and spring, Los Alamos is impacted by midlatitude westerly storms that produce only 8-12 inches of precipitation annually. During the summer, New Mexico experiences a seasonal wind shift, with winds coming from the south. These southerly winds, known as the North American Monsoon (Adams and Comrie 1997), bring warm, moist air and produce an additional 4 inches of rain annually. The annual average rainfall (measured at 7400 feet MSL) of approximately 19 inches falls into the semi-arid range (Peel et al. 2007).

Daily temperatures are highly variable as a result of the limited amount of moisture in the air. On average, winter temperatures range from $35-50^{\circ} \mathrm{F}$ during the day and from $20-25^{\circ} \mathrm{F}$ during the night. The Sangre de Cristo Mountains to the east of the Rio Grande valley act as a barrier to wintertime arctic air masses that descend into the central United States, which cause infrequent local subzero temperatures. Average summer temperatures range from $75-85^{\circ} \mathrm{F}$ during the day and from $50-55^{\circ} \mathrm{F}$ during the night.

The complex topography of the Pajarito Plateau (Figure 2-2) influences local wind patterns. Often a distinct diurnal cycle of wind occurs. Daytime winds measured in the Los Alamos area are predominately from the south to south-southwest, consistent with the typical upslope flow of heated daytime air moving up the Rio Grande valley. Nighttime winds on the Pajarito Plateau are light and typically from the west to northwest as a result of downslope flow of cool air from the Jemez Mountains.

Los Alamos is a light wind site, with the annual average of approximately 7 miles per hour (mph). Spring (April, May, and June) is the windiest season, on average, with low pressure systems strengthening as they flow downstream from the Rocky Mountains. The highest wind gust recorded at a LANL meteorology tower was $85 \mathrm{mph}$ in May 2007.

Severe storms (i.e., life-threatening) are infrequent on the Pajarito Plateau. However, during a typical summer monsoon season, thunderstorms are observed every three to four days. These thunderstorms are often accompanied by strong wind gusts (>40 mph), lightning, and occasionally hail. Dust devils have also been observed periodically in Los Alamos County with winds up to $50 \mathrm{mph}$.

\subsection{LANL METEOROLOGICAL MONITORING}

A National Weather Service cooperative weather station began operation in Los Alamos in November 1910, operated by a local rancher (Machen et al. 2014). The station was eventually taken over by the Los Alamos Ranch School, and then subsequently by the Laboratory. The cooperative station records include measured daily maximum and minimum temperature, midnight temperature and relative humidity, 24-hour rainfall, and 24-hour snowfall. The Los Alamos cooperative weather station has moved several times over 100 years, but the locations have not varied by more than 2 miles and 200 feet in elevation. 


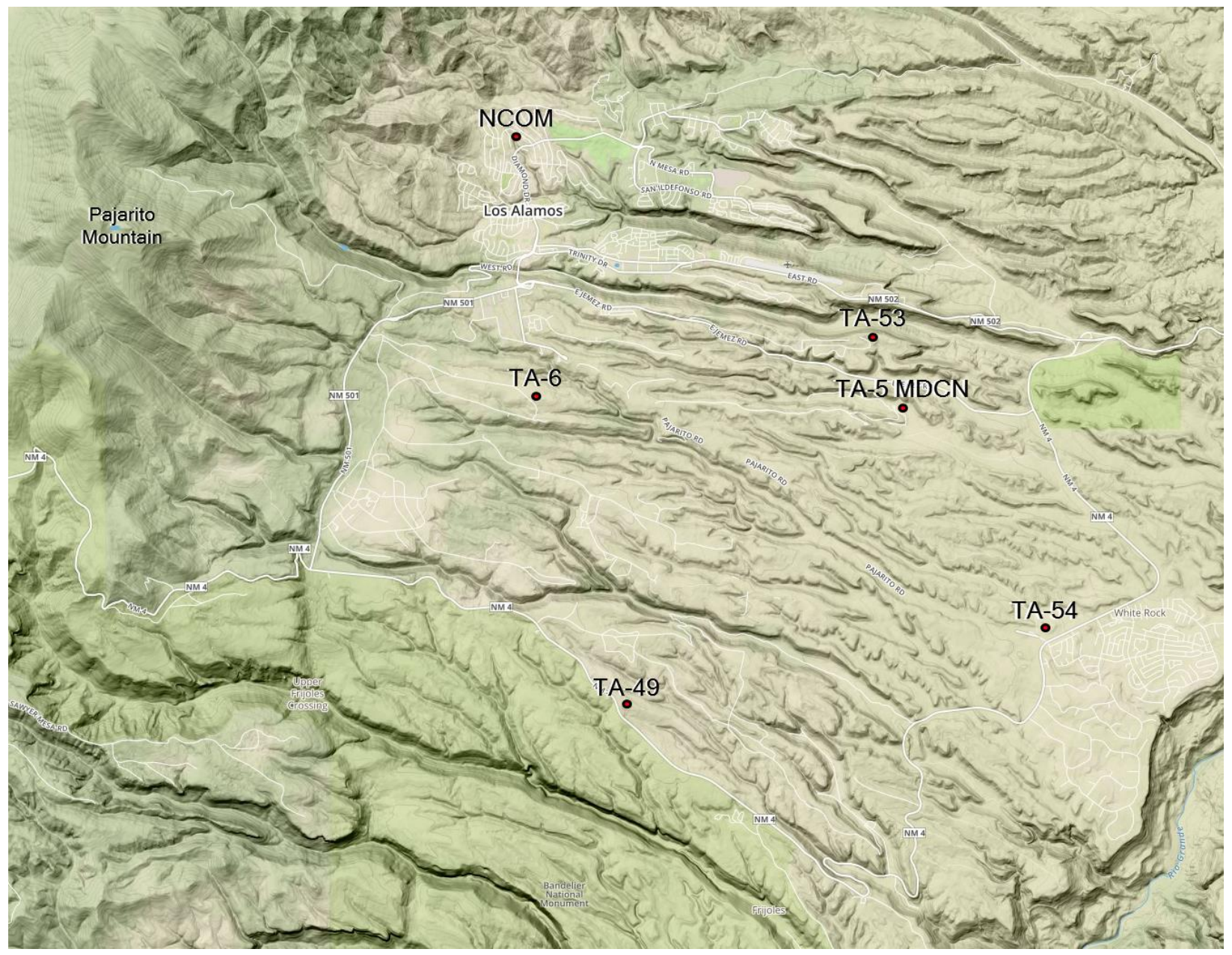

Figure 2-2: Topography of Los Alamos and vicinity. Current meteorology monitoring stations are shown along with the Los Alamos and White Rock residential areas.

The modern digitally-recorded meteorology monitoring began in 1979 and has been revised and expanded since that time (Dewart and Boggs 2014). The tower locations used in this report are presented in Figure 3-1 and described in Table 3-1. TA-6 is the official meteorological station for Los Alamos and the Laboratory. Included in this report are two stations that have a significant operational history but are no longer operated (TA-41 and PJMT [Pajarito Mountain]). LANL has operated meteorology towers at other locations than those presented in Table 3-1 and Figure 3-1. These locations are summarized in Dewart and Boggs (2014). The data from these active and historic locations continues to be available through the LANL Weather Machine website on the internal site, http://weather.lanl.gov, and on the public site, http://environweb.lanl.gov/weathermachine/. 


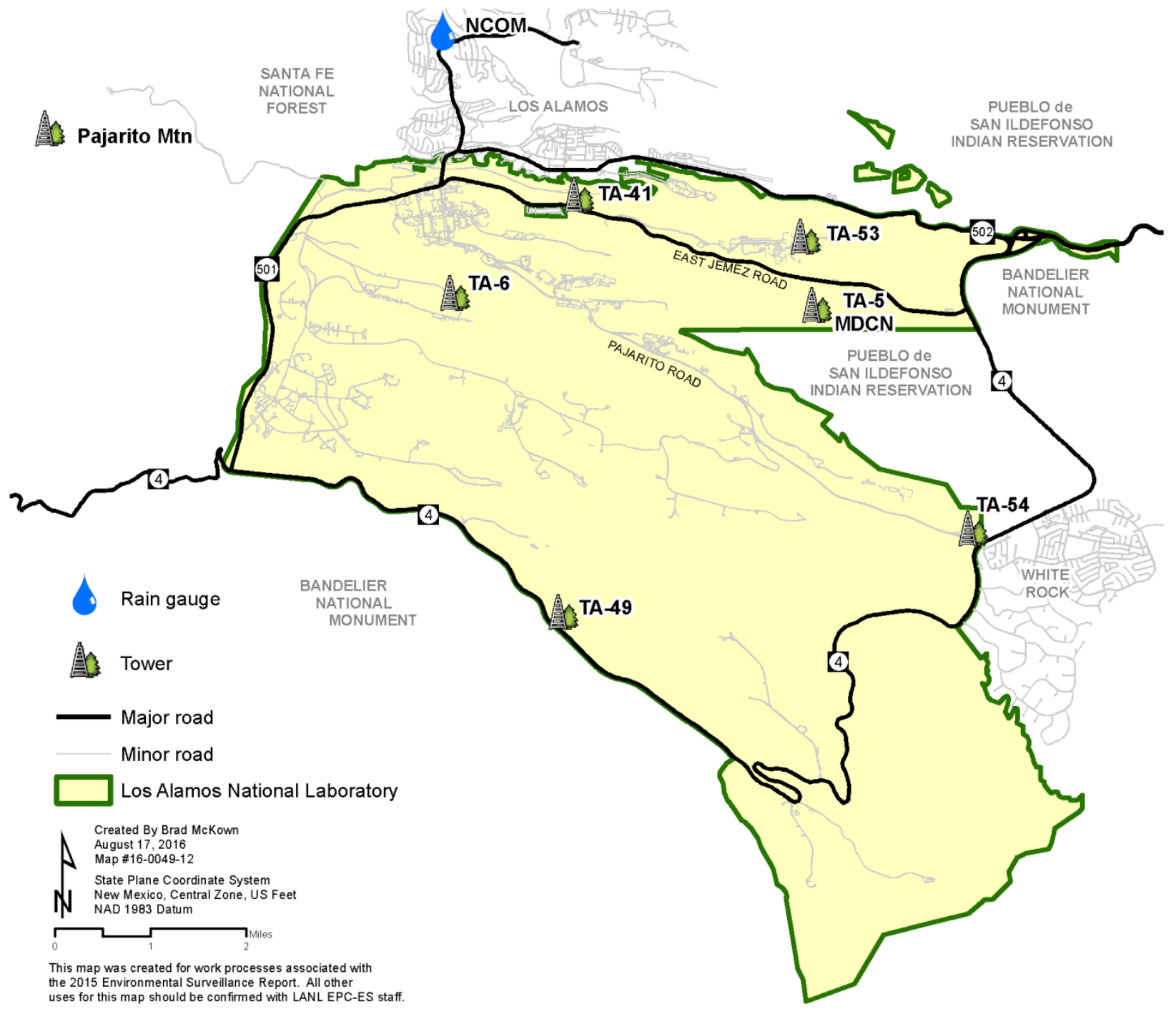

Figure 3-1: Location of meteorological monitoring stations at Los Alamos. TA-41 and Pajarito Mountain are no longer operational. 
Table 3-1: Meteorological Monitoring Stations and Summary of Meteorological Measurements at Each Location

\begin{tabular}{|c|c|c|c|c|c|c|c|c|c|}
\hline \multirow[t]{2}{*}{$\begin{array}{l}\text { Station } \\
\text { Name }\end{array}$} & \multirow[t]{2}{*}{$\begin{array}{l}\text { Alternate } \\
\text { Name(s) }\end{array}$} & \multirow{2}{*}{$\begin{array}{l}\text { LANL } \\
\text { Structure } \\
\text { Number }\end{array}$} & \multicolumn{2}{|c|}{$\begin{array}{l}\text { Latitude/Longitude } \\
\text { Coordinates }\left({ }^{\circ}\right)\end{array}$} & \multirow[t]{2}{*}{$\begin{array}{l}\text { Elevation } \\
\text { (feet) }\end{array}$} & \multirow[t]{2}{*}{$\begin{array}{l}\text { Surface Measurements } \\
\text { (at } 1.5 \text { meters) }\end{array}$} & \multirow{2}{*}{$\begin{array}{l}\text { Tower Levels } \\
\text { of } \\
\text { Measurements } \\
\text { (meters) }\end{array}$} & \multirow[t]{2}{*}{$\begin{array}{c}\text { Tower } \\
\text { Measurements }\end{array}$} & \multirow[t]{2}{*}{$\begin{array}{c}\text { Record of } \\
\text { Observations }\end{array}$} \\
\hline & & & Latitude & Longitude & & & & & \\
\hline TA-6 & Los Alamos & TA-06-0078 & 35.8615 & 106.3195 & 7424 & $\begin{array}{l}\text { Temperature, pressure, humidity, } \\
\text { shortwave radiation, longwave } \\
\text { radiation, precipitation }\end{array}$ & $12,23,46,92$ & $\begin{array}{l}\text { Wind speed, wind } \\
\text { direction, } \\
\text { temperature }\end{array}$ & Feb 1990-present \\
\hline $\begin{array}{l}\text { TA-6 } \\
\text { SODAR }^{\mathrm{a}}\end{array}$ & SODAR & TA-06-0100 & 35.8615 & 106.3187 & 7417 & $N / A^{b}$ & $100-1000^{c}$ & $\begin{array}{l}\text { Wind speed, wind } \\
\text { direction, } \\
\text { temperature }\end{array}$ & Dec 2014-present \\
\hline TA-49 & Bandelier & TA-49-0123 & 35.8133 & 106.2993 & 7045 & $\begin{array}{l}\text { Temperature, humidity, } \\
\text { shortwave radiation, precipitation }\end{array}$ & $12,23,46$ & $\begin{array}{l}\text { Wind speed, wind } \\
\text { direction, } \\
\text { temperature }\end{array}$ & Jun 1987-present \\
\hline TA-53 & LANSCE $^{d}$ & TA-53-1020 & 35.8701 & 106.2543 & 6990 & $\begin{array}{l}\text { Temperature, humidity, } \\
\text { shortwave radiation, precipitation }\end{array}$ & $12,23,46$ & $\begin{array}{l}\text { Wind speed, wind } \\
\text { direction, } \\
\text { temperature }\end{array}$ & Feb 1992-present \\
\hline TA-54 & White Rock & TA-54-0088 & 35.8259 & 106.2232 & 6548 & $\begin{array}{l}\text { Temperature, pressure, humidity, } \\
\text { shortwave radiation, longwave } \\
\text { radiation, precipitation }\end{array}$ & $12,23,46$ & $\begin{array}{l}\text { Wind speed, wind } \\
\text { direction, } \\
\text { temperature }\end{array}$ & Jan 1992-present \\
\hline $\begin{array}{l}\text { TA-5 } \\
\text { MDCN }\end{array}$ & $\begin{array}{l}\text { Mortandad } \\
\text { Canyon }\end{array}$ & TA-05-0061 & 35.8597 & 106.2522 & 6750 & Temperature, solar radiation & 10 & $\begin{array}{l}\text { Wind speed, wind } \\
\text { direction }\end{array}$ & Oct 2002-present \\
\hline NCOM & $\begin{array}{c}\text { North } \\
\text { Community }\end{array}$ & $\mathrm{N} / \mathrm{A}$ & 35.9009 & 106.3216 & 7420 & Precipitation & $\sim 10^{\mathrm{e}}$ & $\mathrm{N} / \mathrm{A}$ & Jan 1996-present \\
\hline $\mathrm{TA}-41^{\dagger}$ & $\begin{array}{l}\text { Los Alamos } \\
\text { Canyon }\end{array}$ & $\mathrm{N} / \mathrm{A}$ & 35.8764 & 106.2964 & 6914 & Temperature, solar radiation & 12,23 & $\begin{array}{l}\text { Wind speed, wind } \\
\text { direction, } \\
\text { temperature }\end{array}$ & $\begin{array}{l}\text { Nov 1993-Oct } \\
2015\end{array}$ \\
\hline PJMT ${ }^{f}$ & $\begin{array}{l}\text { Pajarito } \\
\text { Mountain }\end{array}$ & $\mathrm{N} / \mathrm{A}$ & 35.8864 & 106.3948 & 10,360 & Temperature, precipitation & 36 & $\begin{array}{l}\text { Wind speed, wind } \\
\text { direction, } \\
\text { temperature }\end{array}$ & $\begin{array}{l}\text { Aug 1997-Aug } \\
2013\end{array}$ \\
\hline
\end{tabular}

a SODAR $=$ Sound detection and ranging.

b N/A = not applicable.

${ }^{\mathrm{c}}$ Measurements every 20 meters depending upon current weather conditions.

d LANSCE $=$ Los Alamos Neutron Science Center

e Located on the rooftop.

${ }^{f}$ Station no longer in operation. 
In addition to the five active meteorology towers, LANL installed a SODAR (Sound detection and ranging) instrument at the TA-6 meteorology tower site in 2014. The SODAR produces sound waves projected vertically into the atmosphere to measure wind speed, direction, and temperature above the tower measurement levels. Under certain meteorological conditions, data can be collected as high as 1 kilometer above the surface. SODAR data will be analyzed and presented in future publications.

LANL meteorological instrumentation is required to meet specifications in the Department of Energy handbook Environmental Radiological Effluent Monitoring and Environmental Surveillance (DOE 2015). The handbook adopts the American National Standards Institute (ANSI 2010) and Environmental Protection Agency (EPA 2000) guidance for meteorology monitoring. LANL measures meteorology parameters once every 3 seconds, averages these measurements over 15 minutes, and calculates 24-hour means and extremes from the 3-second data. Quality assurance review of the data is performed using automated range checks and visual inspections of trend plots on a daily, weekly, monthly, and annual basis by the project meteorologists. LANL meteorology data are made available to customers via the LANL Weather Machine.

As noted earlier, the long-term climatological averages presented in this report are for Los Alamos and White Rock data collected from 1981-2010. To make comparisons across the Pajarito Plateau, the 1994-2013 period was selected to allow the comparison of data from all of the mesa-top towers (TA-6, TA-54, TA-49, and TA-53). This period is drier and warmer than the 1981-2010 period, thus the focus on these site-wide comparisons will be the relative differences rather than the absolute differences in meteorology parameters. Data are also analyzed for two canyon locations, TA-41 and TA-5 MDCN (Figure 3-2), and on Pajarito Mountain to compare with the mesa-top tower data. TA-41 has complete data available for 1994-2013, TA-5 MDCN for 2003-2013, and PJMT for 1998-2012.

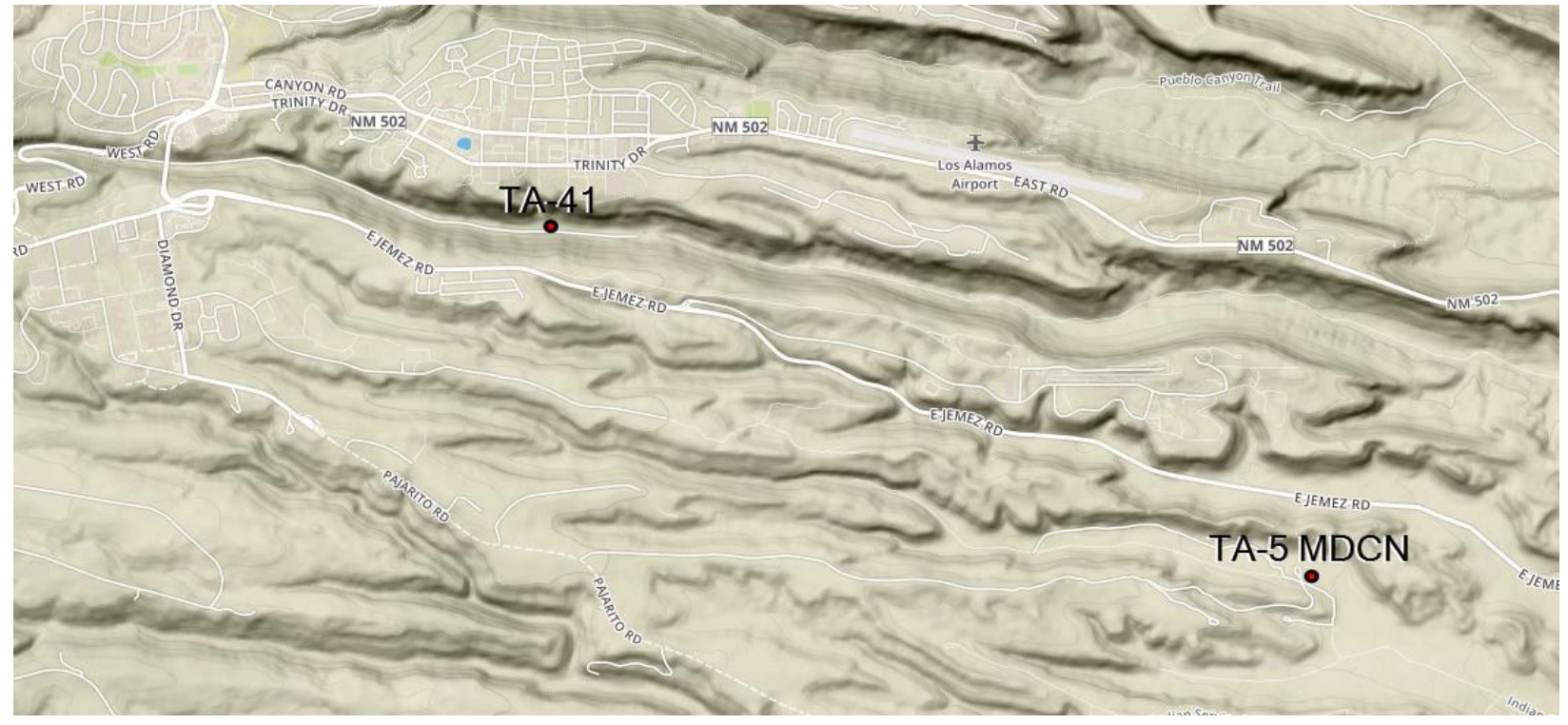

Figure 3-2: Canyon locations of meteorology towers. 


\subsection{TEMPERATURE}

Various temperature measurements are available in Los Alamos going back to 1918. Complete years of temperature measurements are available for Los Alamos since 1924 and in White Rock since 1964. These data are used to characterize the basic temperature patterns on the Pajarito Plateau. The expansion of the meteorological tower network during the late 1980s and early 1990s has provided more data for characterizing temperature differences across the Laboratory.

\subsection{Average Temperatures}

Surface temperatures (at approximately 1.5 meters above ground level [AGL]) are influenced by the time of day, large scale weather patterns, and local geography. The local influences on temperature include length of day, altitude, topography, vegetation, cloud cover/humidity, and wind speeds. Therefore, the temperatures vary significantly across LANL. The 1981-2010 average temperatures are presented for Los Alamos and White Rock (Table 4-1 and Figure 4-1) as these stations represent the primary LANL monitoring locations; additional station data are presented in Section 4.5 to demonstrate the temperature variability across LANL.

Table 4-1: $\quad$ Monthly Average Temperatures for Los Alamos and White Rock in ${ }^{\circ} \mathrm{F}$ (1981-2010)

\begin{tabular}{|l|c|c|c|c|c|c|}
\cline { 2 - 7 } \multicolumn{1}{c|}{} & \multicolumn{3}{c|}{ Los Alamos } & \multicolumn{3}{c|}{ White Rock } \\
\cline { 2 - 7 } \multicolumn{1}{c|}{} & $\begin{array}{c}\text { Max. } \\
\text { Temp. }\end{array}$ & $\begin{array}{c}\text { Min. } \\
\text { Temp. }\end{array}$ & $\begin{array}{c}\text { Ave. } \\
\text { Temp. }\end{array}$ & $\begin{array}{c}\text { Max. } \\
\text { Temp. }\end{array}$ & $\begin{array}{c}\text { Min. } \\
\text { Temp. }\end{array}$ & $\begin{array}{c}\text { Ave. } \\
\text { Temp. }\end{array}$ \\
\hline January & 39.8 & 18.9 & 29.4 & 42.9 & 16.1 & 29.5 \\
\hline February & 43.7 & 22.1 & 32.9 & 47.9 & 20.6 & 34.2 \\
\hline March & 51.3 & 27.5 & 39.4 & 55.9 & 26.7 & 41.3 \\
\hline April & 59.8 & 33.9 & 46.8 & 64.2 & 33.2 & 48.7 \\
\hline May & 69.2 & 42.8 & 56.0 & 73.9 & 42.0 & 57.9 \\
\hline June & 78.8 & 51.4 & 65.1 & 83.6 & 50.1 & 66.8 \\
\hline July & 81.3 & 55.1 & 68.2 & 86.3 & 55.2 & 70.8 \\
\hline August & 78.0 & 53.5 & 65.8 & 83.3 & 54.1 & 68.7 \\
\hline September & 72.3 & 47.3 & 59.8 & 77.0 & 46.4 & 61.7 \\
\hline October & 61.4 & 36.9 & 49.2 & 65.5 & 34.9 & 50.2 \\
\hline November & 49.0 & 26.7 & 37.9 & 52.5 & 24.4 & 38.5 \\
\hline December & 39.7 & 19.2 & 29.4 & 42.6 & 16.2 & 29.4 \\
\hline Annual & 60.4 & 36.3 & 48.3 & 64.6 & 35.0 & 49.8 \\
\hline
\end{tabular}

Average temperatures in White Rock are a few degrees higher than Los Alamos throughout the year. During the summertime, daily average high temperatures in White Rock are as much as $5^{\circ} \mathrm{F}$ warmer than Los Alamos. On average, White Rock is warmer than Los Alamos as a result of the drier and less cloudy conditions in White Rock, White Rock receives more incoming solar radiation (insolation), and White Rock's lower elevation results in higher air density. This higher air density, which produces warmer temperatures as a result of more longwave radiation from the earth's surface, can be absorbed by the air in White Rock compared with the air in the Los Alamos townsite. The resulting annual average difference in temperature between Los Alamos in White Rock is $1.5^{\circ} \mathrm{F}$. 


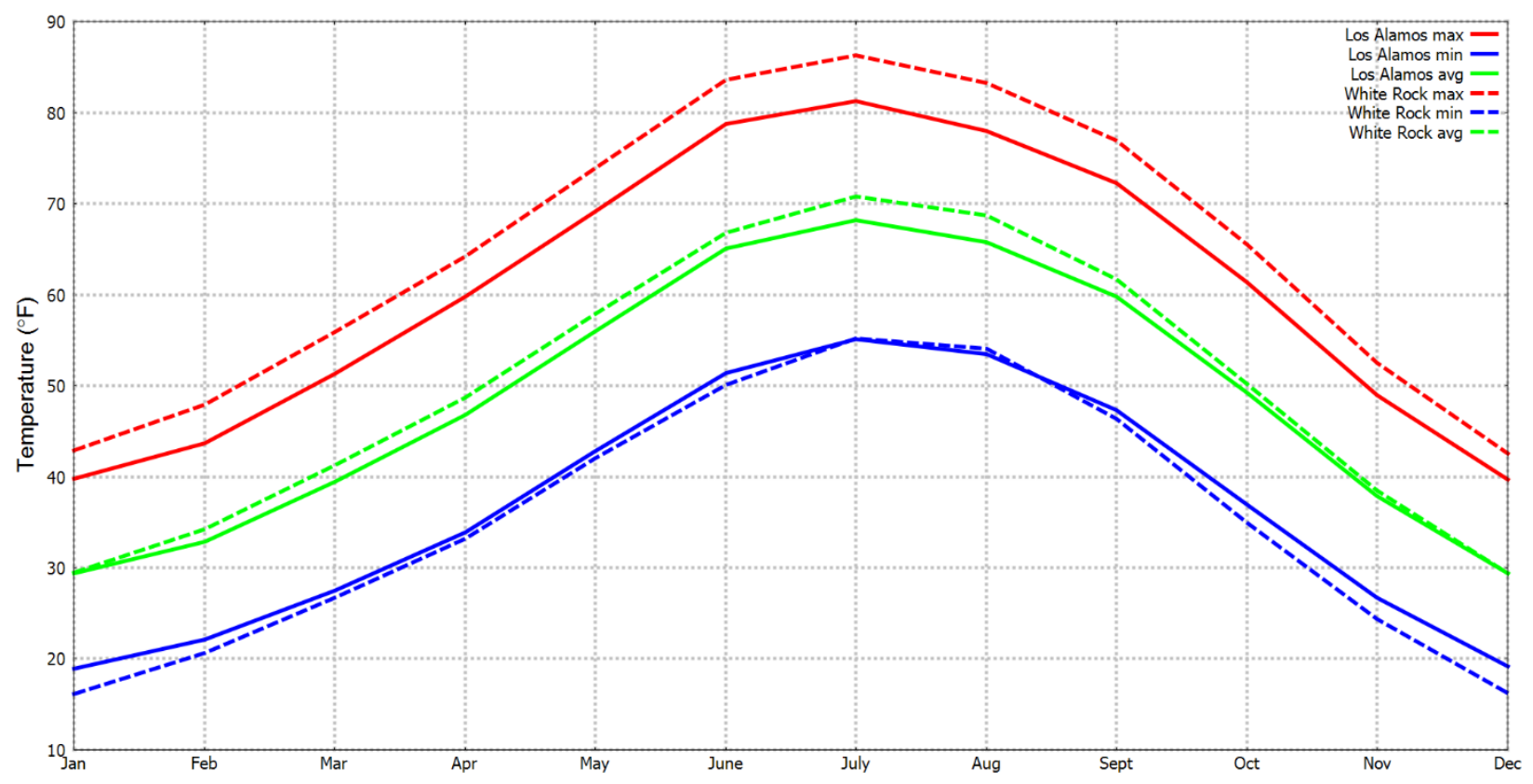

Figure 4-1: Monthly average temperatures for Los Alamos and White Rock (1981-2010).

The overnight low temperatures in White Rock during the fall, winter, and spring months are colder than Los Alamos. Colder temperatures in White Rock are produced during calm nights, when cold air drains off the Jemez Mountains, and pools in White Rock where the topography levels out. Since White Rock is less cloudy than Los Alamos, the surface cools off more at night than in Los Alamos, and this also contributes to the colder air temperatures at night. On average, White Rock is as much as $3^{\circ} \mathrm{F}$ colder than Los Alamos on winter nights. Monthly average temperatures for Los Alamos (1951-2015) and White Rock (1965-2015) are presented in the appendix.

The differences in temperature from day to night reflect the significant amount of days with clear skies and generally low humidity. Since the skies are often clear, solar radiation heats up the surface of the earth and the air next to the ground is heated. At night, with few clouds and low humidity, the ground radiates heat away and the air next to the ground cools off quickly. The average day/night fluctuation in temperatures is $20-30^{\circ} \mathrm{F}$, depending upon the time of year.

On average in Los Alamos, there were three days per year with high temperatures of $90^{\circ} \mathrm{F}$ or greater, with a range from no days above $90^{\circ} \mathrm{F}$ (multiple years) to 22 days above $90^{\circ} \mathrm{F}$ during 1980 . During 1980 , the large number of days with high temperatures above $90^{\circ} \mathrm{F}$ was the product of a very weak (dry) monsoon season. Total precipitation during the summer monsoon season of 1980 was 3.5 inches, compared with the average of 9.95 inches. In White Rock, there were 35 days per year with high temperatures of $90^{\circ} \mathrm{F}$ or greater, with a range of four days above $90^{\circ} \mathrm{F}$ (1992) to 50 days above $90^{\circ} \mathrm{F}$ during 2002. During 2002, the large number of days with high temperatures above $90^{\circ} \mathrm{F}$ was also the product of a weak monsoon season. Total precipitation in White Rock during the summer of 2002 was 5.32 inches, compared with the average of 6.91 inches.

Los Alamos had 1.5 days per year with an overnight low temperature of $0^{\circ} \mathrm{F}$ or below, ranging from no days below $0^{\circ} \mathrm{F}$ (multiple years) to eight days with temperatures below $0^{\circ} \mathrm{F}$ during 1963 . These episodes are usually produced by a cold arctic air outbreak that has pushed from eastern New Mexico into Los Alamos; typically, the Sangre de Cristo Mountains protect Los Alamos from these cold air 
intrusions. For White Rock, there are two days per year with low temperatures at and below $0^{\circ} \mathrm{F}$, ranging from no days (multiple years) to 13 days during 1967.

\subsection{Temperature Extremes}

The warmest temperatures in Los Alamos and White Rock are observed during dry periods of June or July. The coolest temperatures are observed on calm, clear winter nights, often with snow on the ground. These nights may be accompanied by cold air outbreaks when artic air from the eastern plains pushes westward across New Mexico. The record high temperatures in Los Alamos and White Rock are $96^{\circ} \mathrm{F}$ and $101^{\circ} \mathrm{F}$, respectively. The record low temperatures in Los Alamos and White Rock are $-18^{\circ} \mathrm{F}$ and $-29^{\circ} \mathrm{F}$, respectively. A summary of Los Alamos and White Rock extreme temperatures are presented in Tables 4-2 and 4-3.

Table 4-2: Monthly Extreme Temperatures for Los Alamos (1910-2016)

\begin{tabular}{|c|c|c|c|c|}
\cline { 2 - 5 } \multicolumn{1}{c|}{} & $\begin{array}{c}\text { Highest } \\
\text { Temperature }\left({ }^{\circ} \mathbf{F}\right)\end{array}$ & $\begin{array}{c}\text { Date of Highest } \\
\text { Temperature }\end{array}$ & $\begin{array}{c}\text { Lowest Minimum } \\
\text { Temperature }\left({ }^{\circ} \mathbf{F}\right)\end{array}$ & $\begin{array}{c}\text { Date of Lowest } \\
\text { Temperature }\end{array}$ \\
\hline January & 64 & $1 / 12 / 1953$ & -18 & $1 / 13 / 1963$ \\
\hline February & 69 & $2 / 25 / 1986$ & -16 & $2 / 3 / 2011$ \\
\hline March & 74 & $3 / 31 / 2012$ & -3 & $3 / 11 / 1948$ \\
\hline April & 80 & $4 / 23 / 1950$ & 5 & $4 / 9 / 1928$ \\
\hline May & 92 & $5 / 31 / 2002$ & 22 & $5 / 3 / 2013$ \\
\hline June & 96 & $6 / 19 / 2016$ & 28 & $6 / 3 / 1919$ \\
\hline July & 95 & $7 / 11 / 1935$ & 37 & $7 / 7 / 1924$ \\
\hline August & 92 & $8 / 11 / 2012$ & 38 & $8 / 24 / 1918$ \\
\hline September & 90 & $9 / 3 / 1948$ & 23 & $9 / 29 / 1936$ \\
\hline October & 84 & $9 / 1 / 1980$ & 6 & $10 / 30 / 1993$ \\
\hline November & 72 & $11 / 1 / 1950$ & -14 & $11 / 28 / 1976$ \\
\hline December & 69 & $12 / 2 / 1927$ & -12 & $12 / 9 / 1978$ \\
\hline
\end{tabular}

Table 4-3: Monthly Extreme Temperatures for White Rock (1964-2016)

\begin{tabular}{|c|c|c|c|c|}
\cline { 2 - 5 } \multicolumn{1}{c|}{} & $\begin{array}{c}\text { Highest } \\
\text { Temperature }\left({ }^{\circ} \mathbf{F}\right)\end{array}$ & $\begin{array}{c}\text { Date of Highest } \\
\text { Temperature }\end{array}$ & $\begin{array}{c}\text { Lowest Minimum } \\
\text { Temperature }\left({ }^{\circ} \mathbf{F}\right)\end{array}$ & $\begin{array}{c}\text { Date of Lowest } \\
\text { Temperature }\end{array}$ \\
\hline January & 65 & $1 / 19 / 1986$ & -29 & $1 / 7 / 1971$ \\
\hline February & 73 & $2 / 25 / 1986$ & -22 & $2 / 3 / 2011$ \\
\hline March & 80 & $3 / 24 / 2015$ & -5 & $3 / 3 / 1971$ \\
\hline April & 84 & $4 / 26 / 2000$ & 12 & $4 / 5 / 1983$ \\
\hline May & 96 & $5 / 31 / 2002$ & 18 & $5 / 2 / 1967$ \\
\hline June & 101 & $6 / 19 / 2016$ & 33 & $6 / 14 / 2001$ \\
\hline July & 100 & $7 / 12 / 1971$ & 41 & $7 / 4 / 1995$ \\
\hline August & 98 & $8 / 6 / 1977$ & 38 & $8 / 27 / 1992$ \\
\hline September & 94 & $9 / 13 / 1990$ & 27 & $9 / 25 / 2000$ \\
\hline October & 90 & $10 / 1 / 1980$ & 9 & $10 / 30 / 1993$ \\
\hline November & 73 & $11 / 13 / 1967$ & -14 & $11 / 28 / 1976$ \\
\hline December & 65 & $12 / 5 / 1965$ & -17 & $12 / 9 / 1978$ \\
\hline
\end{tabular}


When the maximum temperature does not get above freezing for consecutive days, it can be an engineering design concern for buildings and evaporation ponds. Each year since 1951 in Los Alamos (with the exception of 1998, 1999, 2000, and 2003) there were several occurrences of multiple consecutive days with temperatures at or below freezing. These events occur between late November and early March. The maximum number of consecutive days with temperatures below freezing was 11, from December 24, 1987, through January 3, 1988.

\subsection{Heating and Cooling Degree Days}

Average temperatures are used to estimate fuel use for heating and cooling buildings. A "degree day" refers to the difference between the daily average temperature and a reference temperature for indoor comfort $\left(65^{\circ} \mathrm{F}\right)$. For example, if the average temperature for a day is $70^{\circ} \mathrm{F}$, a building would require cooling by $5^{\circ} \mathrm{F}$ to reach $65^{\circ} \mathrm{F}$ and thus that day counts as five cooling degree days. Conversely, if the average temperature for a day is $60^{\circ} \mathrm{F}$, a building would require warming by $5^{\circ} \mathrm{F}$ and that day counts as five warming degree days.

The monthly average heating and cooling degree days for Los Alamos and White Rock are presented in Table 4-4 and Figure 4-2. The annual average heating and cooling degree days are typical for the southern Rocky Mountain region (NEO 2016). The greatest difference between the two sites occurs in mid-summer as a result of the significantly warmer temperatures in White Rock.

Table 4-4: $\quad$ Monthly Average Heating and Cooling Degree Days for Los Alamos and White Rock (1981-2010)

\begin{tabular}{|l|c|c|c|c|}
\cline { 2 - 5 } \multicolumn{1}{c|}{} & \multicolumn{2}{c|}{ Los Alamos } & \multicolumn{2}{c|}{ White Rock } \\
\cline { 2 - 5 } \multicolumn{1}{c|}{} & $\begin{array}{c}\text { Heating } \\
\text { Degree Days }\end{array}$ & $\begin{array}{c}\text { Cooling } \\
\text { Degree Days }\end{array}$ & $\begin{array}{c}\text { Heating } \\
\text { Degree Days }\end{array}$ & $\begin{array}{c}\text { Cooling } \\
\text { Degree Days }\end{array}$ \\
\hline January & 1105 & 0 & 1103 & 0 \\
\hline February & 906 & 0 & 868 & 0 \\
\hline March & 794 & 0 & 737 & 0 \\
\hline April & 545 & 0 & 490 & 0 \\
\hline May & 288 & 8 & 232 & 11 \\
\hline June & 69 & 73 & 42 & 100 \\
\hline July & 15 & 114 & 3 & 183 \\
\hline August & 35 & 60 & 9 & 124 \\
\hline September & 167 & 11 & 119 & 25 \\
\hline October & 491 & 0 & 456 & 0 \\
\hline November & 813 & 0 & 799 & 0 \\
\hline December & 1102 & 0 & 1096 & 0 \\
\hline Annual & 6330 & 266 & 5954 & 443 \\
\hline
\end{tabular}




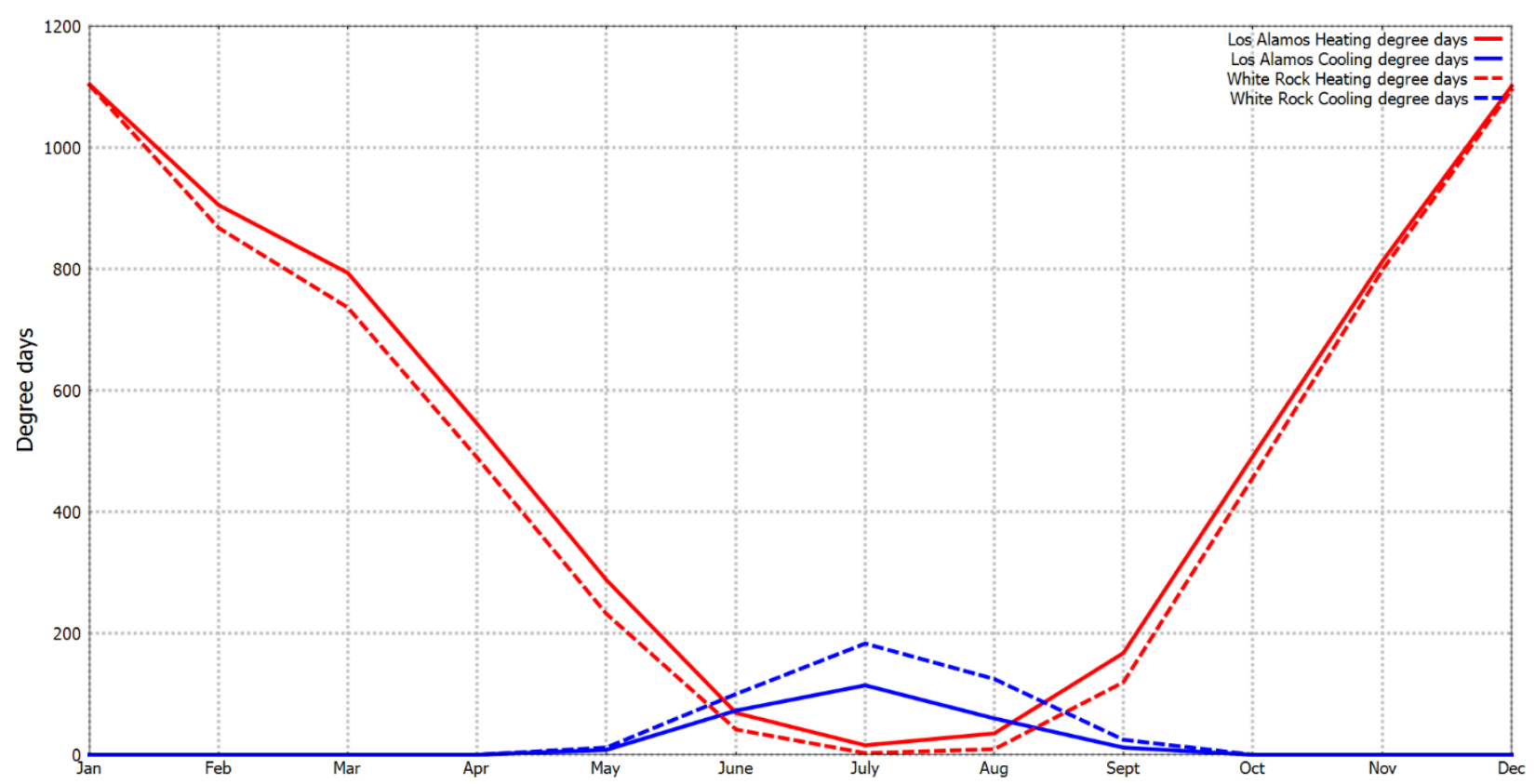

Figure 4-2: Monthly average heating and cooling degree days for Los Alamos and White Rock (1981-2010).

\subsection{Growing Season}

The growing season is defined as the number of days between the last day with freezing temperatures in the spring and the first day with freezing temperatures in the fall. Typically, in Los Alamos and White Rock, the last day with freezing temperatures occurs in early May and the first day with freezing temperatures occurs in early October. At $32^{\circ} \mathrm{F}$, plants can be damaged depending upon the amount of moisture in the air and the length of time the temperature is at or below $32^{\circ} \mathrm{F}$. A hard freeze, when almost all plants will be damaged, is considered to be $28^{\circ} \mathrm{F}$.

The date of the average first freeze in the fall, the date of the last freeze in the spring, and the length of the growing season for Los Alamos and White Rock are presented in Table 4-5. The averages for 1961-1990 are from Bowen (1990). The Los Alamos growing season appears to have shifted forward (earlier) by three to four days for the 1981-2010 period, but the total number of days in the growing season are similar to the 1961-1990 climate averaging period. For White Rock, the growing season has increased by four days, with the last freeze being recorded earlier in the spring with the date of the last fall freeze remaining about the same.

Table 4-5: Average Spring and Fall Freeze Dates

\begin{tabular}{|l|c|c|c|c|}
\cline { 2 - 5 } \multicolumn{1}{c|}{} & \multicolumn{2}{c|}{ Los Alamos } & \multicolumn{2}{c|}{ White Rock } \\
\cline { 2 - 5 } \multicolumn{1}{c|}{} & $\mathbf{1 9 6 1 - 1 9 9 0}$ & $\mathbf{1 9 8 1 - 2 0 1 0}$ & $\mathbf{1 9 6 1 - 1 9 9 0}$ & $\mathbf{1 9 8 1 - 2 0 1 0}$ \\
\hline Date of last freeze in the spring & May 7 & May 4 & May 11 & May 4 \\
\hline Date of earliest freeze in the fall & October 11 & October 7 & October 7 & October 6 \\
\hline Number of days in the growing season & 156 & 155 & 155 & 152 \\
\hline
\end{tabular}


The latest and earliest freeze dates on record are presented in Table 4-6. The dates are not strictly comparable between Los Alamos and White Rock since records for Los Alamos date from 1924 and records for White Rock date from 1964.

Table 4-6: Record Dates of Last Freeze in the Spring and Earliest Freeze in the Fall

\begin{tabular}{|l|c|c|}
\cline { 2 - 3 } \multicolumn{1}{c|}{} & Los Alamos & White Rock \\
\hline Date of last freeze in the spring & June 11, 1975 & May 31, 2011 \\
\hline Date of earliest freeze in the fall & September 9,1941 & September 17, 1968 \\
\hline
\end{tabular}

\subsection{Temperature Variation Across the Laboratory}

LANL currently operates four meteorology towers (TA-6, TA-49, TA-53, and TA-54) on the mesa tops. Data were collected for the years 1994-2013 at each of these towers; temperature averages are taken from these 20 years for comparison. TA-5 MDCN began data collection in late 2002, so for this analysis, the years 2003-2013 are included (11 years). Data for the full years 1998-2012 are available for PJMT (15 years). The data for TA-5 MDCN and PJMT compared with the other sites will not have the same years as the other towers and this will be considered in making comparisons.

The annual average daily maximum and minimum temperatures at each tower are presented in Tables 4-7 and 4-8 and Figures 4-3 and 4-4. Highest summertime and wintertime maximum temperatures occur at the lowest elevations (TA-54 and TA-5 MDCN), the lowest temperatures occur at PJMT (3000-4000 feet higher in altitude than other LANL monitoring locations). Daily maximum temperatures at PJMT are $10-20^{\circ} \mathrm{F}$ lower than the other locations.

The lowest summertime minimum temperatures occur at the highest elevations (PJMT) and in canyons and lower elevations where nighttime cold air drainage occurs (TA-5 MDCN, TA-41, and TA-54). The lowest wintertime minimum temperatures occur in the lowest elevations (TA-54 and TA-5 MDCN) and at TA-41 as a result of nighttime cold air drainage.

Table 4-7: Monthly Average Maximum Temperatures in ${ }^{\circ} \mathrm{F}$

\begin{tabular}{|l|c|c|c|c|c|c|c|}
\cline { 2 - 7 } \multicolumn{1}{c|}{} & TA-6 & TA-54 & TA-53 & TA-49 & TA-41 & $\begin{array}{c}\text { TA-5 } \\
\text { MDCN }\end{array}$ & PJMT \\
\hline January & 40.1 & 43.3 & 41.4 & 41.4 & 37.7 & 44.9 & 32.8 \\
\hline February & 43.4 & 47.6 & 45.4 & 45.2 & 43.3 & 47.1 & 33.2 \\
\hline March & 52.6 & 57.0 & 54.9 & 54.7 & 54.5 & 58.1 & 40.0 \\
\hline April & 60.0 & 64.4 & 62.3 & 62.1 & 62.9 & 65.4 & 46.6 \\
\hline May & 70.2 & 75.1 & 72.9 & 72.6 & 73.7 & 75.5 & 57.2 \\
\hline June & 80.3 & 85.2 & 83.3 & 82.7 & 83.7 & 86.8 & 67.5 \\
\hline July & 82.1 & 87.1 & 85.6 & 85.0 & 85.4 & 89.7 & 70.2 \\
\hline August & 79.2 & 84.2 & 82.4 & 82.1 & 82.3 & 85.7 & 66.4 \\
\hline September & 72.9 & 77.6 & 75.8 & 75.7 & 75.6 & 79.1 & 60.4 \\
\hline October & 61.4 & 65.4 & 63.4 & 63.6 & 61.8 & 67.3 & 49.8 \\
\hline November & 49.9 & 53.2 & 51.9 & 51.4 & 47.5 & 56.0 & 40.5 \\
\hline December & 39.6 & 42.4 & 40.9 & 40.9 & 36.7 & 43.4 & 31.9 \\
\hline Annual & 61.0 & 65.2 & 63.3 & 63.1 & 62.1 & 66.6 & 49.7 \\
\hline
\end{tabular}


Table 4-8: $\quad$ Monthly Average Minimum Temperatures in ${ }^{\circ} \mathrm{F}$

\begin{tabular}{|l|c|c|c|c|c|c|c|}
\cline { 2 - 7 } \multicolumn{1}{c|}{} & TA-6 & TA-54 & TA-53 & TA-49 & TA-41 & $\begin{array}{c}\text { TA-5 } \\
\text { MDCN }\end{array}$ & PJMT \\
\hline January & 19.6 & 15.6 & 22.5 & 22.1 & 14.6 & 12.8 & 18.6 \\
\hline February & 22.0 & 19.8 & 25.4 & 24.5 & 18.6 & 16.4 & 17.7 \\
\hline March & 28.3 & 26.0 & 31.9 & 30.7 & 25.7 & 23.6 & 23.4 \\
\hline April & 34.1 & 32.4 & 37.8 & 36.3 & 31.9 & 29.5 & 28.3 \\
\hline May & 43.7 & 41.3 & 47.9 & 46.1 & 40.8 & 38.1 & 38.2 \\
\hline June & 52.7 & 50.0 & 56.7 & 54.8 & 48.9 & 46.7 & 46.8 \\
\hline July & 56.0 & 55.2 & 59.9 & 58.2 & 54.1 & 52.7 & 50.6 \\
\hline August & 54.4 & 53.9 & 58.2 & 56.4 & 52.8 & 52.1 & 49.1 \\
\hline September & 48.0 & 46.2 & 52.1 & 50.5 & 45.6 & 43.2 & 43.1 \\
\hline October & 37.2 & 34.2 & 41.0 & 39.8 & 34.0 & 31.9 & 34.1 \\
\hline November & 27.6 & 23.6 & 31.0 & 30.1 & 24.0 & 20.5 & 26.1 \\
\hline December & 19.5 & 15.6 & 22.6 & 22.1 & 15.0 & 12.7 & 17.9 \\
\hline Annual & 36.9 & 34.5 & 40.6 & 39.3 & 33.8 & 31.7 & 32.8 \\
\hline
\end{tabular}

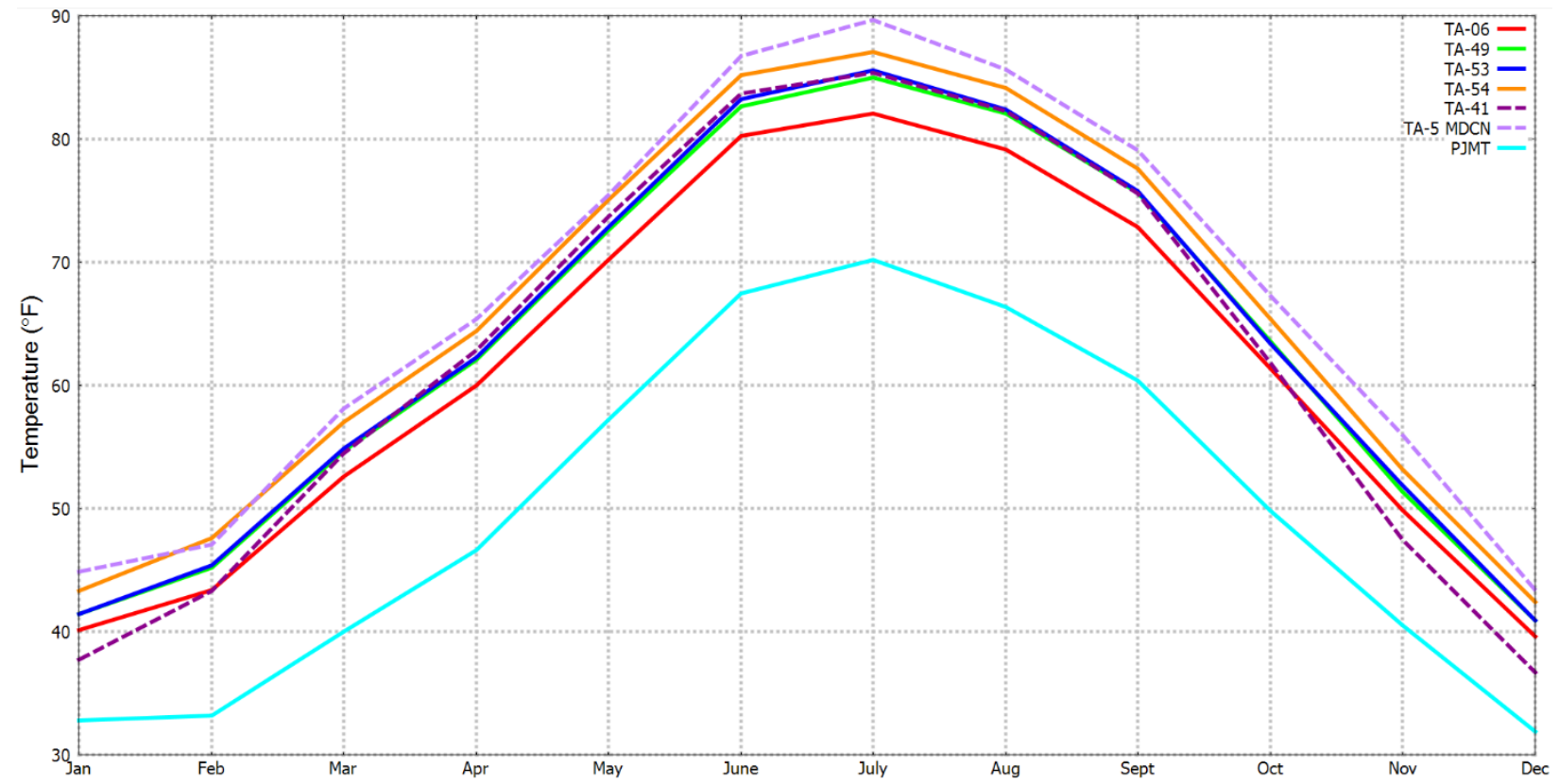

Figure 4-3: Monthly average maximum temperatures across Los Alamos County. 


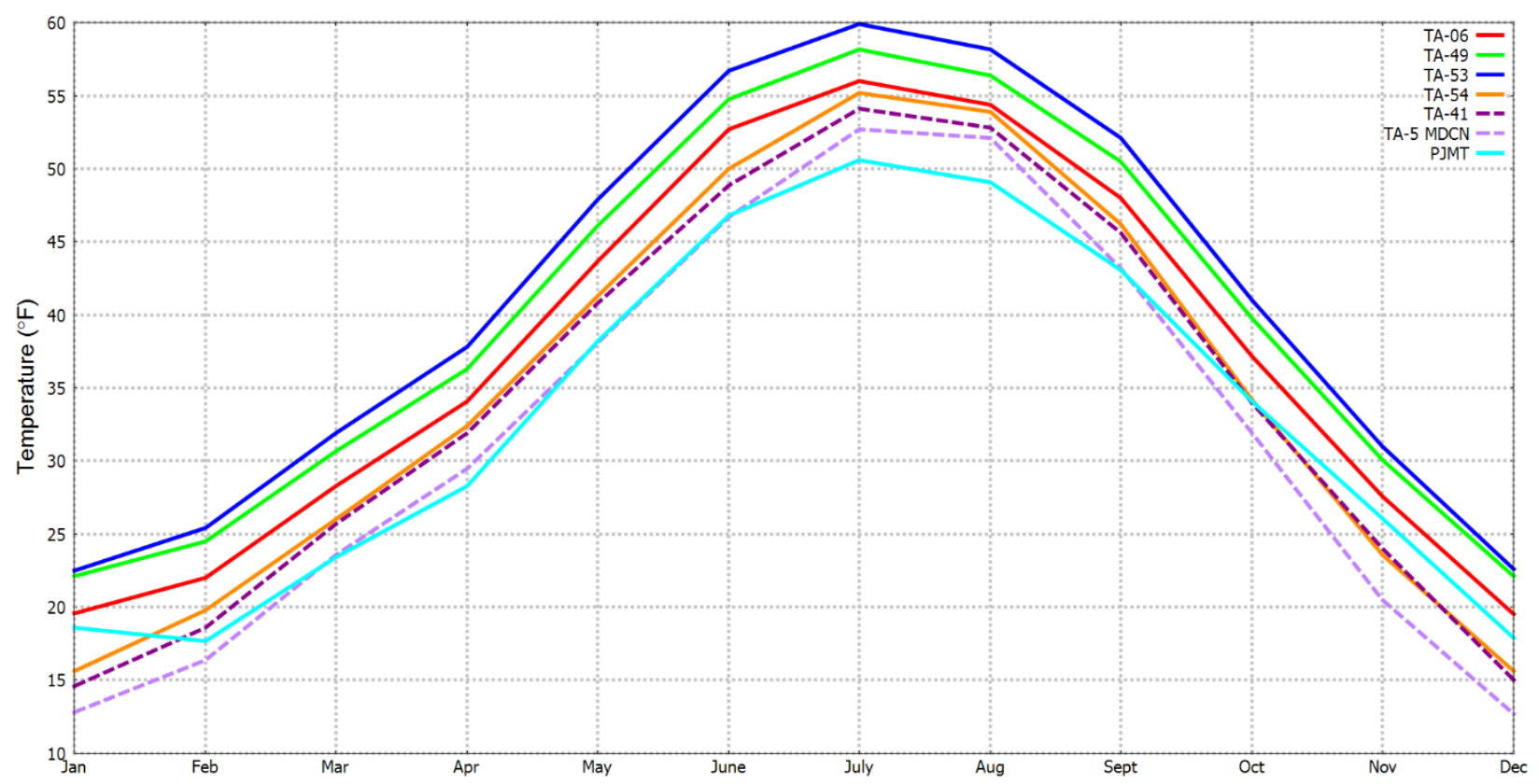

Figure 4-4: Monthly average minimum temperatures across Los Alamos County.

\subsection{PRECIPITATION AND ATMOSPHERIC MOISTURE}

Collection of rain and snowfall data began in November 1910 on the Pajarito Plateau by a scientifically-minded dryland farmer (Machen et al. 2014). However, the data collected during the early years include many months/years with incomplete data. Thus, statistics are presented as early as 1951 where complete years of data are generally available.

In addition to rain and snowfall measurements, atmospheric humidity parameters have been collected at all tower locations from 1987-1992. These data are the precursors of precipitation.

\subsection{Average Precipitation}

The annual average precipitation (rain plus melted snow) in Los Alamos is 18.97 inches (Table 5-1 and Figure 5-1). Approximately 50\% of the annual precipitation falls during the summer monsoon season (June 15-September 30). White Rock has a similar annual distribution of precipitation, but at $75 \%$ of the Los Alamos averages, with an annual average of 14.17 inches. Precipitation in October is often enhanced by the impact of moisture carried into New Mexico from hurricanes or tropical storms off the coast of Mexico in the Eastern Pacific. 
Table 5-1: Monthly Average Precipitation and Snowfall in Inches for Los Alamos and White Rock (1981-2010)

\begin{tabular}{|l|c|c|c|}
\cline { 2 - 4 } \multicolumn{1}{c|}{} & $\begin{array}{c}\text { Los Alamos Average } \\
\text { Precipitation }\end{array}$ & $\begin{array}{c}\text { Los Alamos Average } \\
\text { Snowfall }\end{array}$ & $\begin{array}{c}\text { White Rock Average } \\
\text { Precipitation }\end{array}$ \\
\hline January & 0.95 & 13.3 & 0.66 \\
\hline February & 0.86 & 10.9 & 0.62 \\
\hline March & 1.20 & 10.4 & 0.95 \\
\hline April & 1.06 & 3.4 & 0.84 \\
\hline May & 1.39 & 0.3 & 1.07 \\
\hline June & 1.51 & 0.0 & 1.06 \\
\hline July & 2.82 & 0.0 & 1.92 \\
\hline August & 3.61 & 0.0 & 2.39 \\
\hline September & 2.01 & 0.0 & 1.54 \\
\hline October & 1.55 & 2.2 & 1.51 \\
\hline November & 0.98 & 4.9 & 0.83 \\
\hline December & 1.10 & 12.2 & 0.78 \\
\hline Annual & 18.97 & 57.6 & 14.17 \\
\hline
\end{tabular}

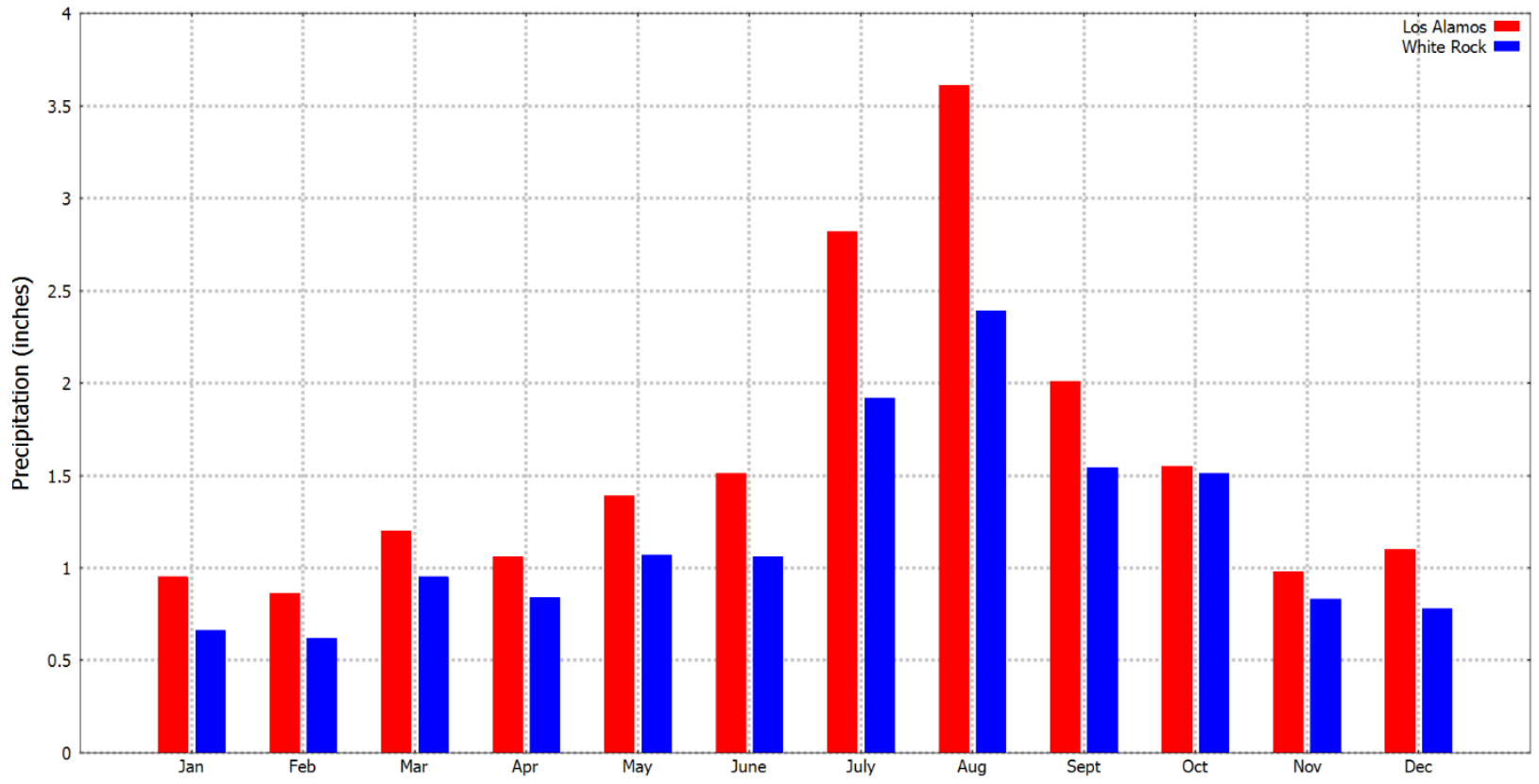

Figure 5-1: Monthly average precipitation for Los Alamos and White Rock (1981-2010).

Winter season precipitation generally falls as snow. Los Alamos receives about 57 inches of snow per year (Figure 5-2). Snow has been recorded in every month of the year, except for June, July, and August. Measureable snow (>0.1 inches) has fallen as early as September 18 (1971) and as late as May 17 (1986). The average first measureable snow is November 10 and the average last date for measureable snow is April 5. A typical snowfall to precipitation (melted snow) ratio is between 
10 inches of snow to 1 inch of rain and 20 inches of snow to 1 inch of rain. In the colder winter months of December, January, and February (when the capacity of the air to hold moisture is less), the snowfall to precipitation ratio is typically 20 to 1 and sometimes higher. In the warmer winter months of November, March, and April, the snowfall to precipitation ratio is closer to 10 to 1 .

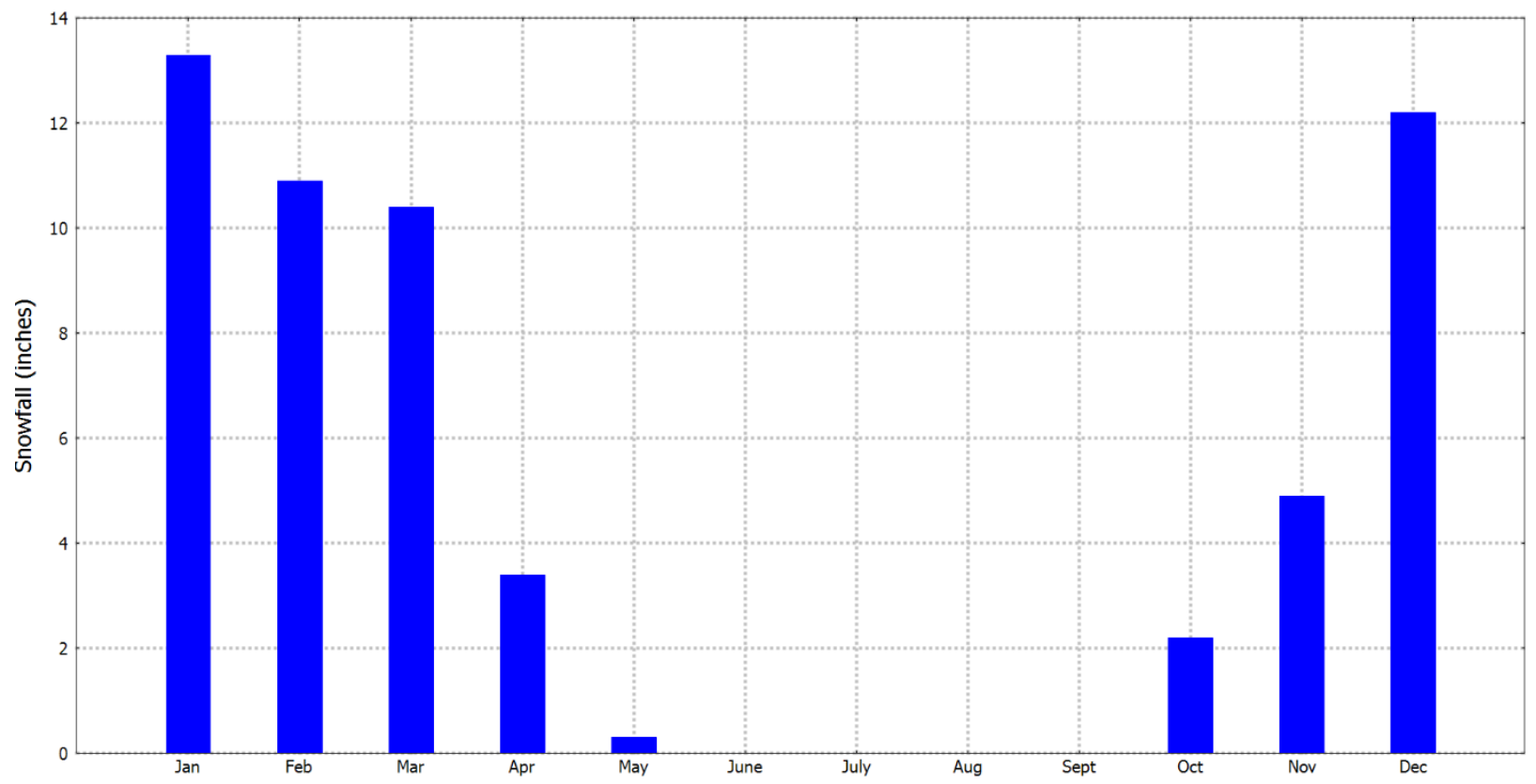

Figure 5-2: $\quad$ Monthly average snowfall in Los Alamos (1981-2010).

The greatest snowstorm and total snowfall for the year occurred in 1986-1987. On January 15-17, 1987, Los Alamos measured 48 inches of snow. The snowfall to precipitation ratio for this storm was 33 to 1 because the average temperature over these three days was $18^{\circ} \mathrm{F}$. Another storm on February 18-19, 1987, produced 26 inches of snow. For the 1986-1987 winter season, a total of 153 inches of snow fell, more than $250 \%$ of normal.

\subsection{Monsoon Season Precipitation}

Precipitation is brought to New Mexico via the midlatitude westerly winds during the fall, winter, and spring. As the jet stream moves north in the late spring/early summer, Los Alamos typically comes under the influence of the North American Monsoon weather pattern (Adams 1997). During the summer months, the Bermuda high pressure moves west into the Gulf of Mexico and the central high plains of the United States and a low pressure area is created by the high temperatures of the Phoenix, Arizona-Las Vegas, Nevada areas. These circulations combine to bring moisture into Mexico, and produce southerly winds that bring this moisture into Arizona and New Mexico (Figure 5-3). In 2008, the National Weather Service defined the North American Monsoon season as June 15 to September 30 (Sampson and Pytlak 2008). This report uses this definition even though significant rainfalls that have a moisture source in Mexico typically begin during the first week in July in Los Alamos.

The 1981-2010 average monsoon precipitation in Los Alamos is 9.28 inches and has ranged from as low as 3.15 inches in 1956 to as high as 17.58 inches in 1952. The 1981-2010 average monsoon 
precipitation in White Rock is 6.46 inches and has ranged from as low as 1.66 inches in 1980 and as high as 13.33 inches in 2013.

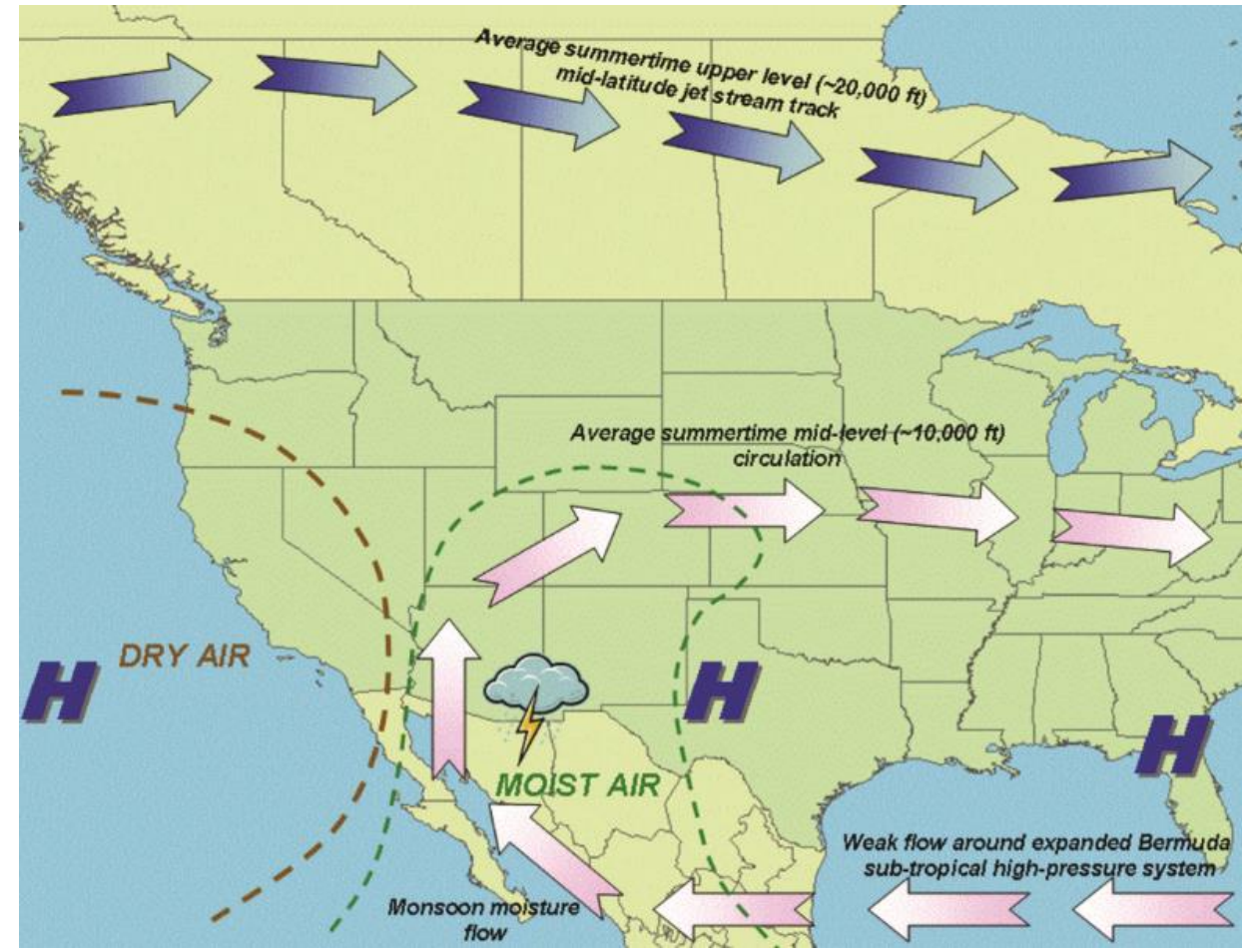

Figure 5-3: $\quad$ Schematic of surface wind patterns during the North American Monsoon (Crimmins 2006).

\subsection{Precipitation Across Los Alamos}

Precipitation across the site varies with altitude and distance from the steep rise of the terrain just west of LANL. When the wind blows from the east or from the south, air is lifted by the mountains (known as orographic lifting), causing the air to cool and promoting cloud and rain or snow formation. Thus, the highest average total precipitation (rain and melted snow) occurs at the stations with highest altitude and closest to the mountains (TA-6 and NCOM). The average precipitation across the Laboratory is presented in Table 5-2 and Figure 5-4. TA-49 and TA-53 are at similar altitudes, but TA-49 is about 1 mile closer to the mountains than TA-53, and this produces higher precipitation. TA-54 is located at the lowest elevation and is the farthest distance from the mountains, resulting in the lowest average precipitation. All stations record the highest average precipitation during the summer monsoon season. The NCOM station is missing a significant amount of data during the summer of 2005, so the NCOM averages for August and September are biased low.

The spatial pattern is similar for the summer monsoon season; precipitation is greatest at the stations with the highest altitude and closest to the mountains (Figure 5-5). There are two interesting exceptions, precipitation at the NCOM station in 2001 and 2011 dropped in comparison with other stations. This may have been a result of reduced soil moisture following the Cerro Grande and Las Conchas fires. The NCOM station is the closest station to areas with significant burns during these fires, and the severe burns produced hydro-phobic soils. Since these soils cannot hold moisture, there is no recycling of soil moisture after rainstorms to support the next rainstorm. 
Table 5-2: Monthly Average Precipitation Across the Laboratory in Inches (1994-2013)

\begin{tabular}{|l|c|c|c|c|c|}
\cline { 2 - 6 } \multicolumn{1}{c|}{} & TA-6 & TA-54 & TA-53 & TA-49 & NCOM \\
\hline January & 0.82 & 0.55 & 0.66 & 0.77 & 0.76 \\
\hline February & 0.76 & 0.52 & 0.64 & 0.71 & 0.73 \\
\hline March & 0.89 & 0.75 & 0.80 & 0.83 & 0.89 \\
\hline April & 1.10 & 0.86 & 0.94 & 1.02 & 1.14 \\
\hline May & 1.02 & 0.69 & 0.88 & 0.91 & 1.00 \\
\hline June & 1.18 & 1.01 & 0.85 & 0.96 & 1.26 \\
\hline July & 2.33 & 1.95 & 1.71 & 2.05 & 2.67 \\
\hline August & 3.33 & 2.51 & 2.56 & 2.77 & $3.42^{*}$ \\
\hline September & 2.30 & 1.85 & 1.72 & 2.17 & $1.76^{*}$ \\
\hline October & 1.69 & 1.51 & 1.46 & 1.66 & 1.76 \\
\hline November & 0.79 & 0.66 & 0.64 & 0.80 & 0.74 \\
\hline December & 0.90 & 0.64 & 0.74 & 0.84 & 0.81 \\
\hline Annual & 17.11 & 13.49 & 13.61 & 15.50 & $17.11^{*}$ \\
\hline
\end{tabular}

*These data are biased low due to a significant amount of data missing in 2005.

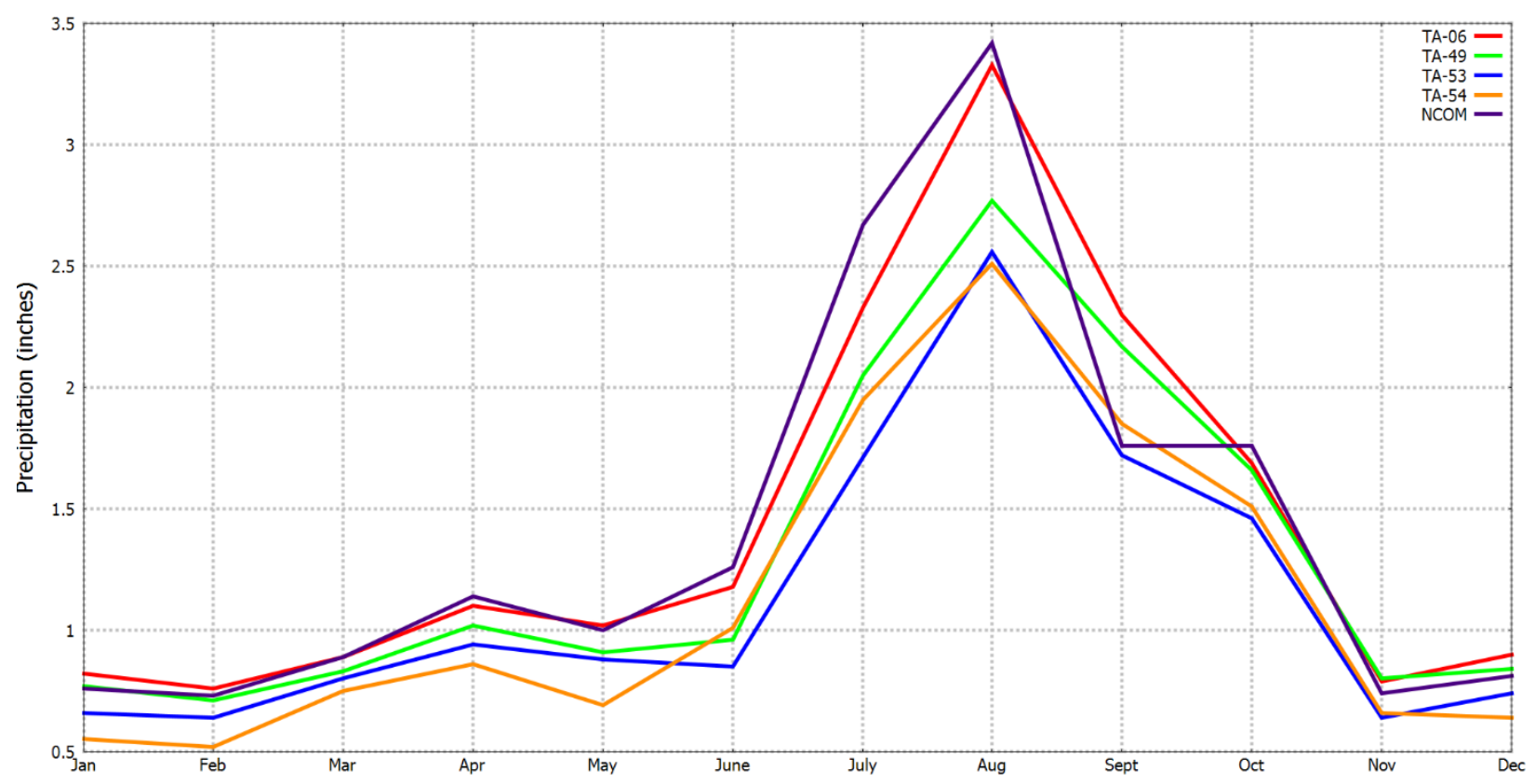

Figure 5-4: Monthly average precipitation across the Laboratory (1994-2013). NCOM August and September averages are low due to missing data during 2005, but the available data are left in the figure for context. 


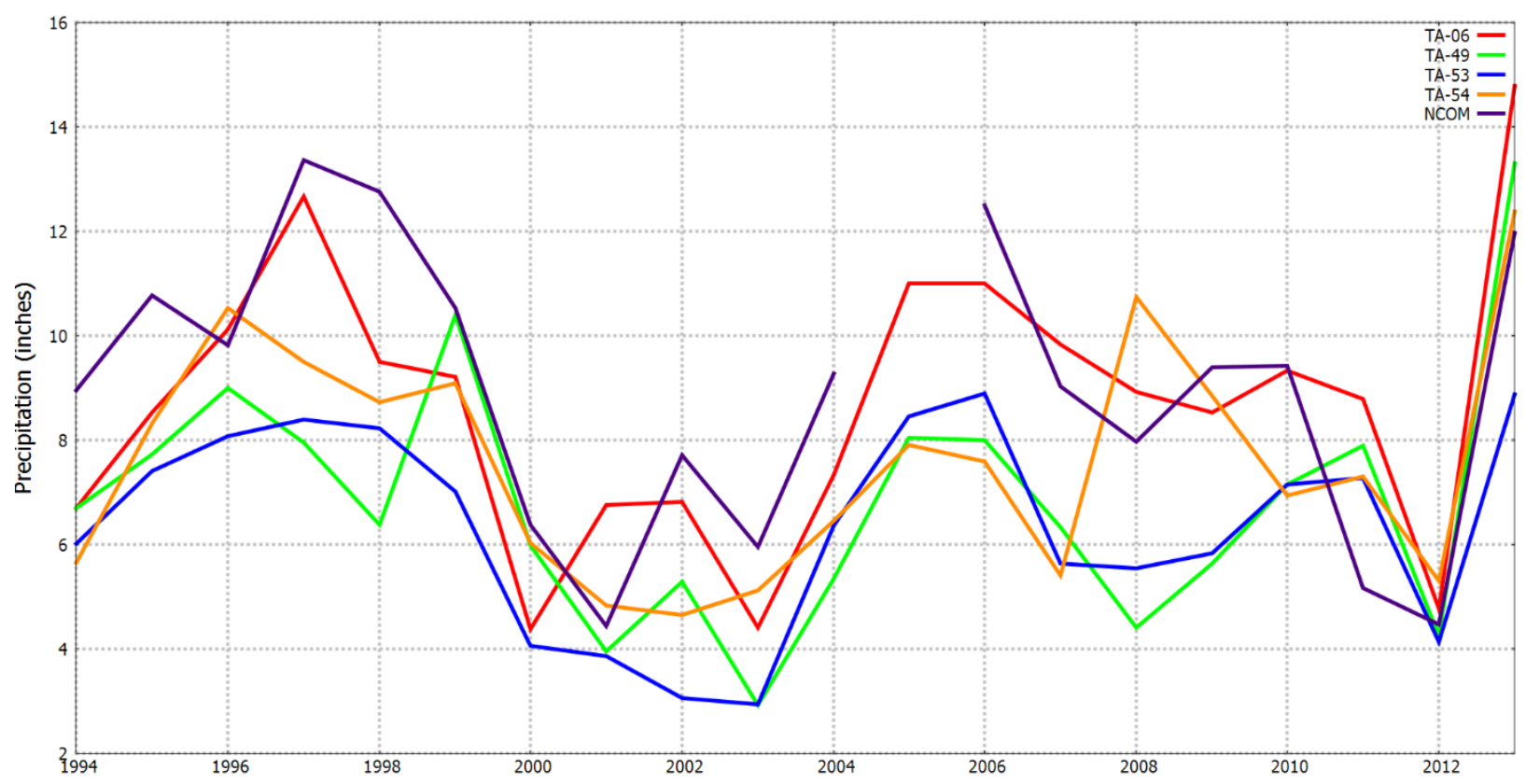

Figure 5-5: Annual average monsoon season precipitation (1994-2013). A significant amount of data is missing for NCOM for August-September 2005; this point was eliminated from the graph.

\subsection{Heavy Precipitation Events}

Daily precipitation totals greater than 0.5 inches can be considered heavy rainfalls with the potential to cause local flooding and property or infrastructure damage. The annual average number of days in Los Alamos recording greater than 0.5 inches of precipitation is 16 days, and in White Rock is 10 days. The majority of these days (55\%) occur during the summer monsoon season. The average monthly distribution of heavy rainfall events is presented in Table 5-3. The record for highest daily precipitation occurred on September 13, 2013, when Los Alamos measured 3.52 inches and White Rock measured 2.49 inches (a description of the September 2013 rainfall event is found in Bruggeman 2016). The 10 greatest daily rainfall totals on record for Los Alamos and White Rock are presented in Table 5-4. The majority of these rain events occurred during the summer monsoon season, but a few have occurred in the spring and winter. Note that due to the much longer record for Los Alamos, there are only two days where the Los Alamos and White Rock stations recorded the highest precipitation on the same dates.

Table 5-3: Monthly Average Number of Days with Precipitation Greater Than 0.5 Inches

\begin{tabular}{|l|c|c|}
\cline { 2 - 3 } \multicolumn{1}{c|}{} & Los Alamos & White Rock \\
\hline January & 0.7 & 0.2 \\
\hline February & 0.4 & 0.2 \\
\hline March & 0.7 & 0.4 \\
\hline April & 1.0 & 0.5 \\
\hline May & 1.1 & 0.8 \\
\hline June & 1.4 & 0.7 \\
\hline
\end{tabular}




\begin{tabular}{|l|c|c|}
\cline { 2 - 3 } \multicolumn{1}{c|}{} & Los Alamos & White Rock \\
\hline July & 2.5 & 1.4 \\
\hline August & 3.1 & 2.2 \\
\hline September & 1.9 & 1.4 \\
\hline October & 1.5 & 1.5 \\
\hline November & 0.9 & 0.6 \\
\hline December & 0.8 & 0.5 \\
\hline Annual & 15.9 & 10.4 \\
\hline
\end{tabular}

Table 5-4: Top 10 Greatest 1-day Rainfall Events for Los Alamos and White Rock

\begin{tabular}{|c|l|c|l|}
\hline \multicolumn{2}{|c|}{ Los Alamos } & \multicolumn{2}{c|}{ White Rock } \\
\hline $\begin{array}{c}\text { Rainfall in inches } \\
(\mathbf{1 9 1 0 - 2 0 1 3 )}\end{array}$ & \multicolumn{1}{|c|}{ Date } & $\begin{array}{c}\text { Rainfall in inches } \\
(\mathbf{1 9 6 4 - 2 0 1 3 )}\end{array}$ & \multicolumn{1}{|c|}{ Date } \\
\hline 3.52 & September 13, 2013 & 2.49 & September 13, 2013 \\
\hline 3.48 & October 5, 1911 & 2.11 & June 17, 1999 \\
\hline 2.51 & June 10, 1913 & 1.93 & October 31, 1989 \\
\hline 2.47 & July, 31, 1968 & 1.88 & July, 31, 1968 \\
\hline 2.45 & January 27, 1916 & 1.79 & September 12, 2013 \\
\hline 2.26 & August 1, 1951 & 1.75 & April 11, 1969 \\
\hline 2.25 & March 30,1916 & 1.71 & August 18, 2000 \\
\hline 2.23 & August 23, 1957 & 1.61 & September 28, 2005 \\
\hline 2.21 & December 19, 1918 & 1.60 & December 11, 1965 \\
\hline 2.21 & September 22, 1929 & 1.60 & July 17, 1975 \\
\hline
\end{tabular}

The Laboratory is required to design nuclear facilities to withstand severe storms. Extreme value statistics along with the LANL measured precipitation values are used to predict return period rainfall and snowfall (e.g., the 100-year return period 24-hour rainfall event). The predicted return period rainfall, snowfall, and wind speeds are presented in Kelly et al. (2015).

\subsection{El Niño/La Niña Influence on Precipitation}

The El Niño Southern Oscillation (ENSO) is one of the most important ocean-atmosphere circulations impacting the weather across the planet. The circulation is characterized by above normal (called El Niño) or below normal (called La Niña) equatorial Pacific Ocean sea surface temperatures. The changes in ocean surface temperature impact the wind and precipitation patterns over the equatorial Pacific and North America. These patterns and their impact on weather in the United States are illustrated in Figure 5-6. 

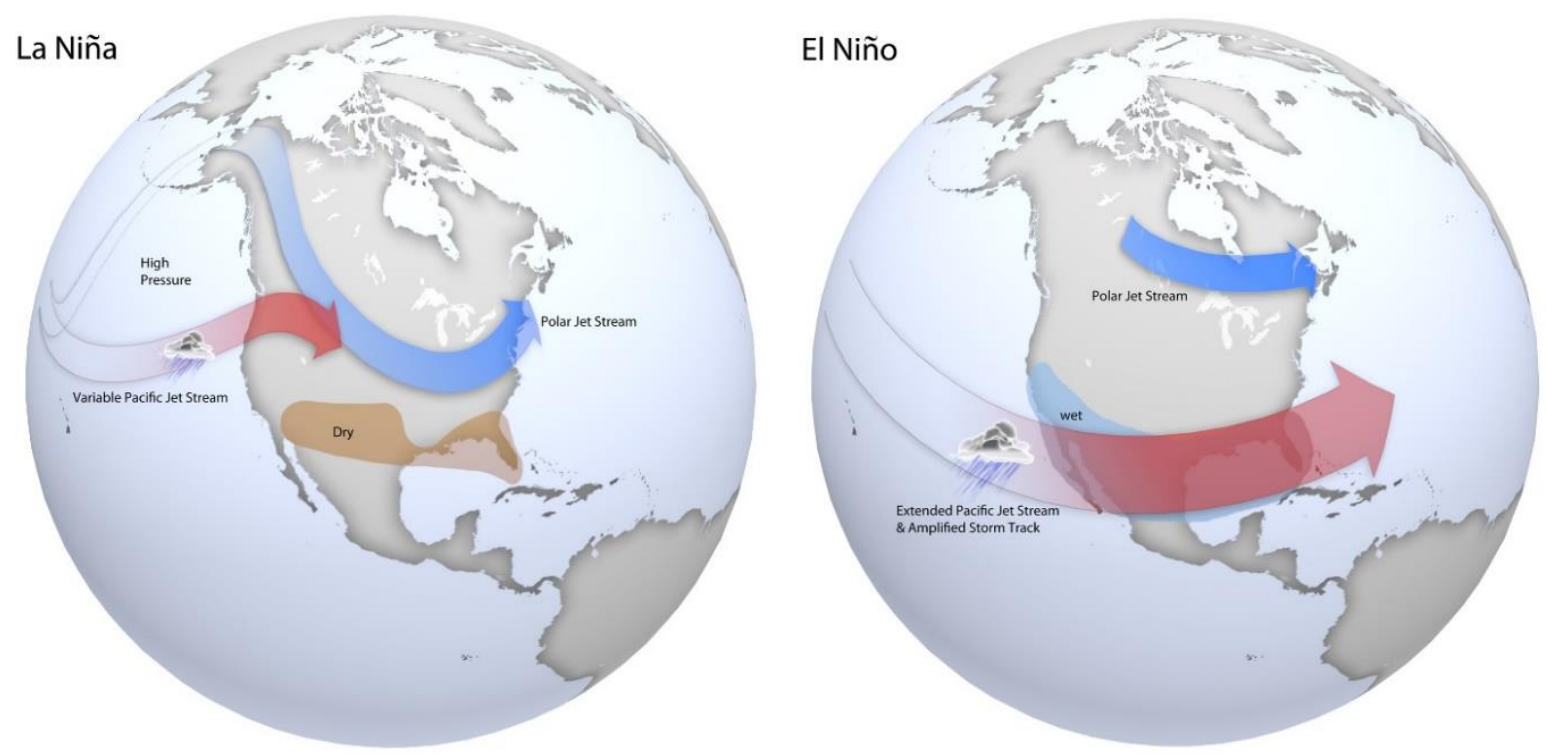

Figure 5-6: Winter atmospheric circulation patterns during El Niño and La Niña winter events (NOAA 2016a).

The presence of an El Niño or La Niña pattern is determined by the three-month average Pacific equatorial sea surface temperature anomaly (difference from the long-term average). El Niño (La Niña) is defined when the three-month average sea surface temperature is greater than $0.5^{\circ} \mathrm{C}$ above (below) normal. As shown in Figure 5-6, wintertime precipitation in Los Alamos is expected to be above average during El Niño years and below average during La Niña years. Figure 5-7 identifies the month-by-month Pacific Ocean sea surface temperature anomaly. Values between $\pm 0.5^{\circ} \mathrm{C}$ are considered to be El Niño/La Niña neutral. Since 1950, there have been $17 \mathrm{El}$ Niño events and 12 La Niña events. The other years are known as El Niño/La Niña neutral years. The average length of La Niña events is 16 months and 11 months for El Niño events.

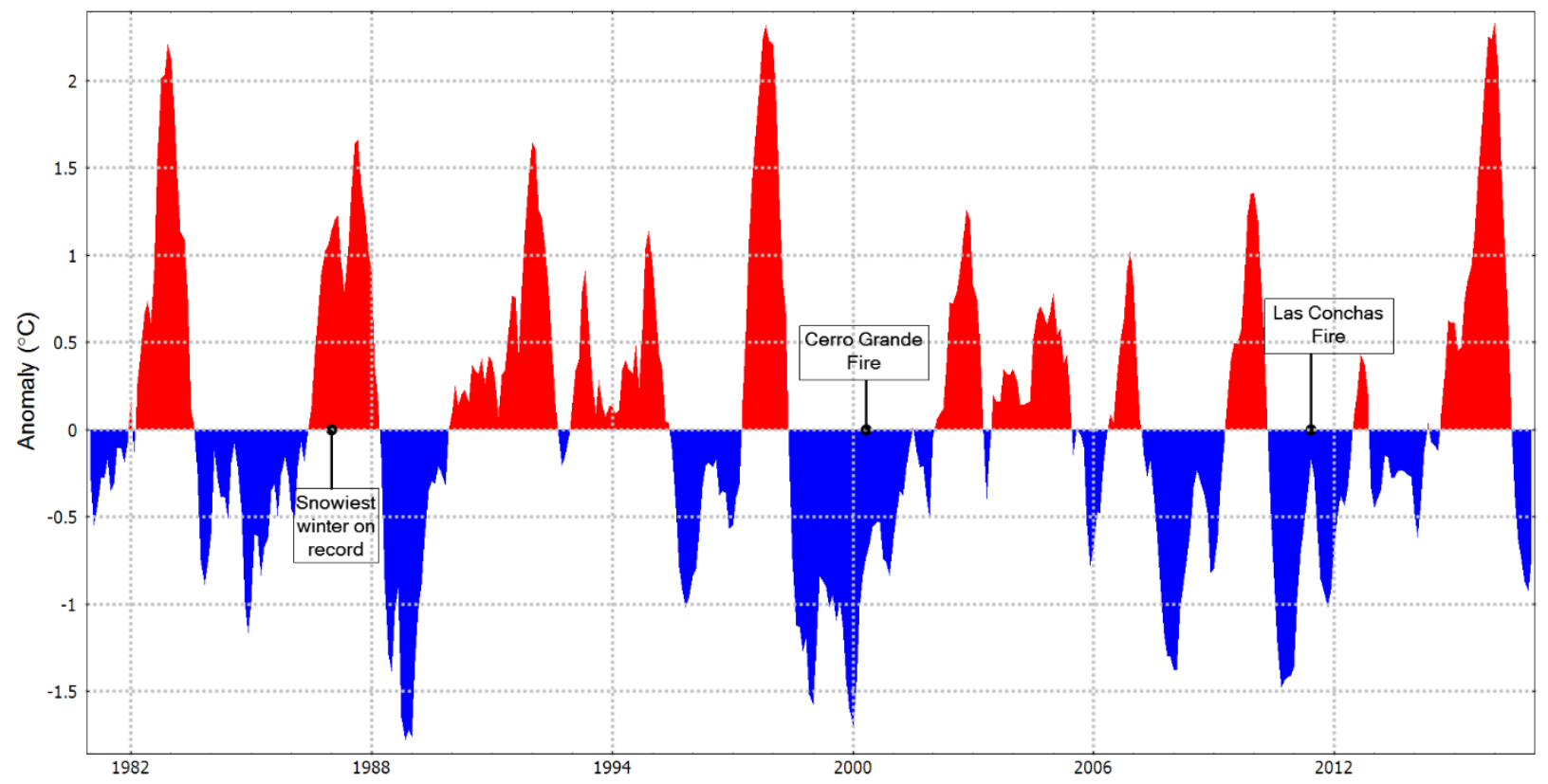

Figure 5-7: Pacific sea surface temperature anomalies (1981-2016) and major Los Alamos weather events. 
To compare Los Alamos precipitation during El Niño and La Niña winters, winter precipitation (rain plus melted snow) is summed for each year between November 1 and March 31. The average winter precipitation for Los Alamos from 1951-1980 is 4.75 inches; from 1981-2010 it is 5 inches. During the El Niño winters for this same period, the average precipitation was 5.35 inches; during the La Niña winters, the average precipitation was 3.78 inches. There is a tendency for Los Alamos to receive slightly greater than normal precipitation in El Niño years and much less than average precipitation in La Niña years. These data, including the winters from 1952-2016, are presented in Figures 5-8 and 5-9. The data demonstrate that an El Niño year is not a guarantee of a wet winter and a La Niña winter is not a guarantee of a dry winter.

Los Alamos average winter precipitation during El Niño/La Niña neutral years is 4.71 inches, slightly below climatological averages. Los Alamos winter precipitation during neutral years are presented in Figure 5-10. Precipitation during neutral years has a larger variability than in either El Niño or La Niña winters. That is, winter precipitation during an El Niño/La Niña neutral winter can be well above or below normal.

Other factors impact winter precipitation in Los Alamos beyond the ENSO circulation. The Pacific Decadal Oscillation (PDO) impacts the amount of winter precipitation received in Los Alamos (Gutzler et al. 2016). The PDO is a cycle of Pacific seas surface temperatures in the middle latitudes. In years when the PDO is positive and El Niño is present, New Mexico tends to receive more winter precipitation. In cases when La Niña is present and the PDO is negative, New Mexico tends to receive less winter precipitation. However, the PDO does not explain each Los Alamos winter when high winter precipitation occurs in La Niña years or when low winter precipitation occurs in El Niño years.

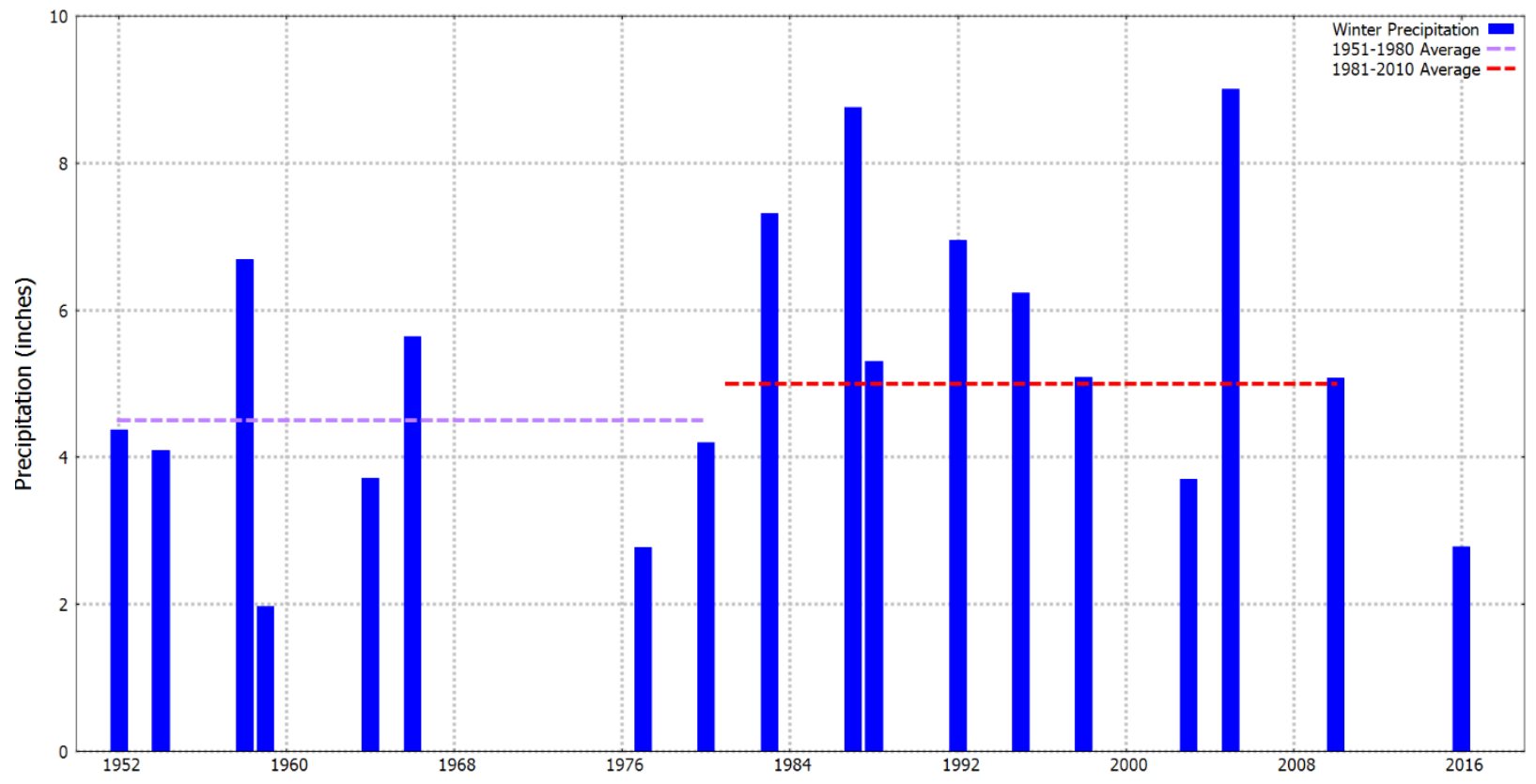

Figure 5-8: $\quad$ Los Alamos precipitation during El Niño winters. The year represents the year of the end of the winter (e.g., 2016 is the winter of 2015-2016). 


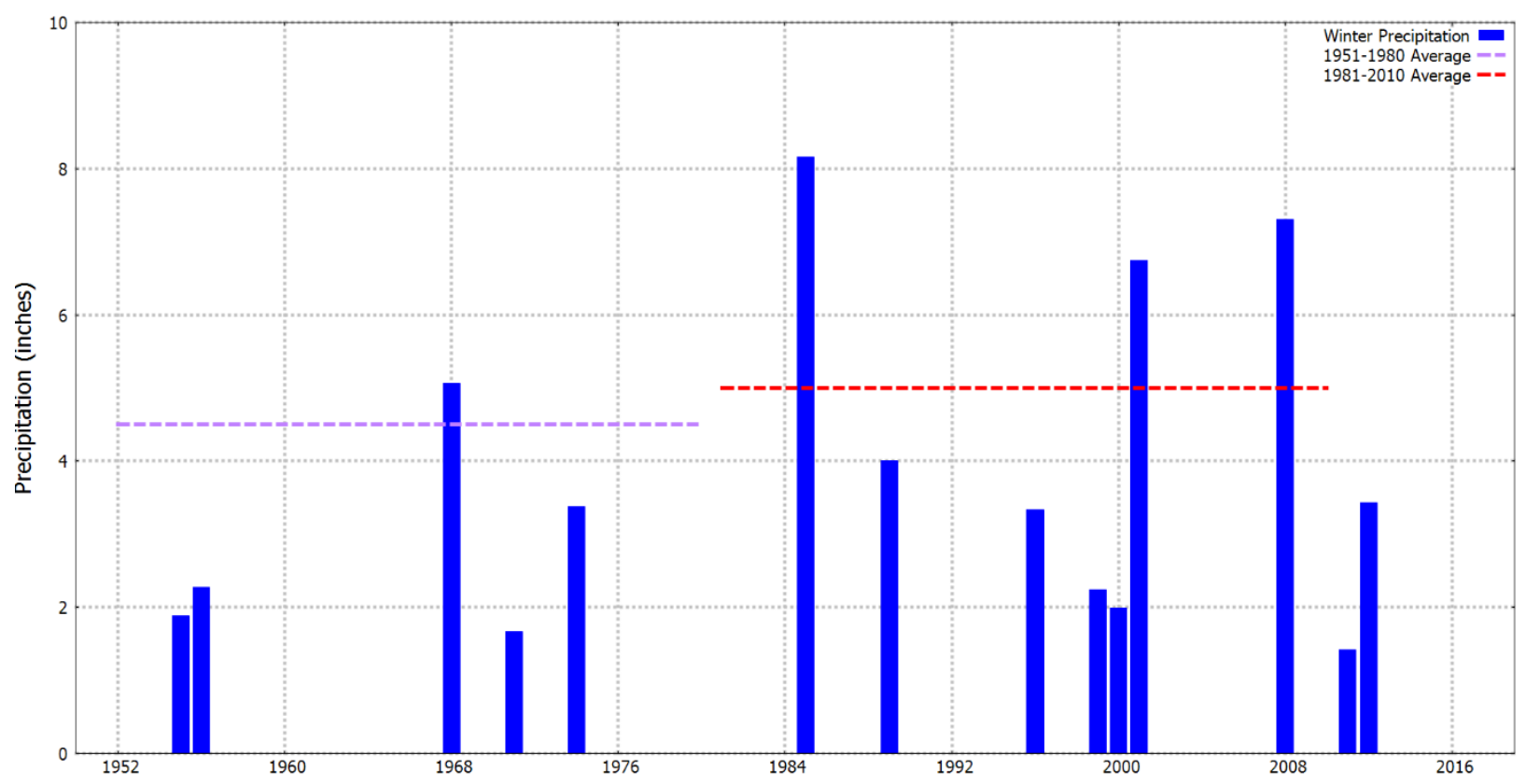

Figure 5-9: Los Alamos precipitation during La Niña years. The year represents the year of the end of the winter (e.g., 2016 is the winter of 2015-2016).

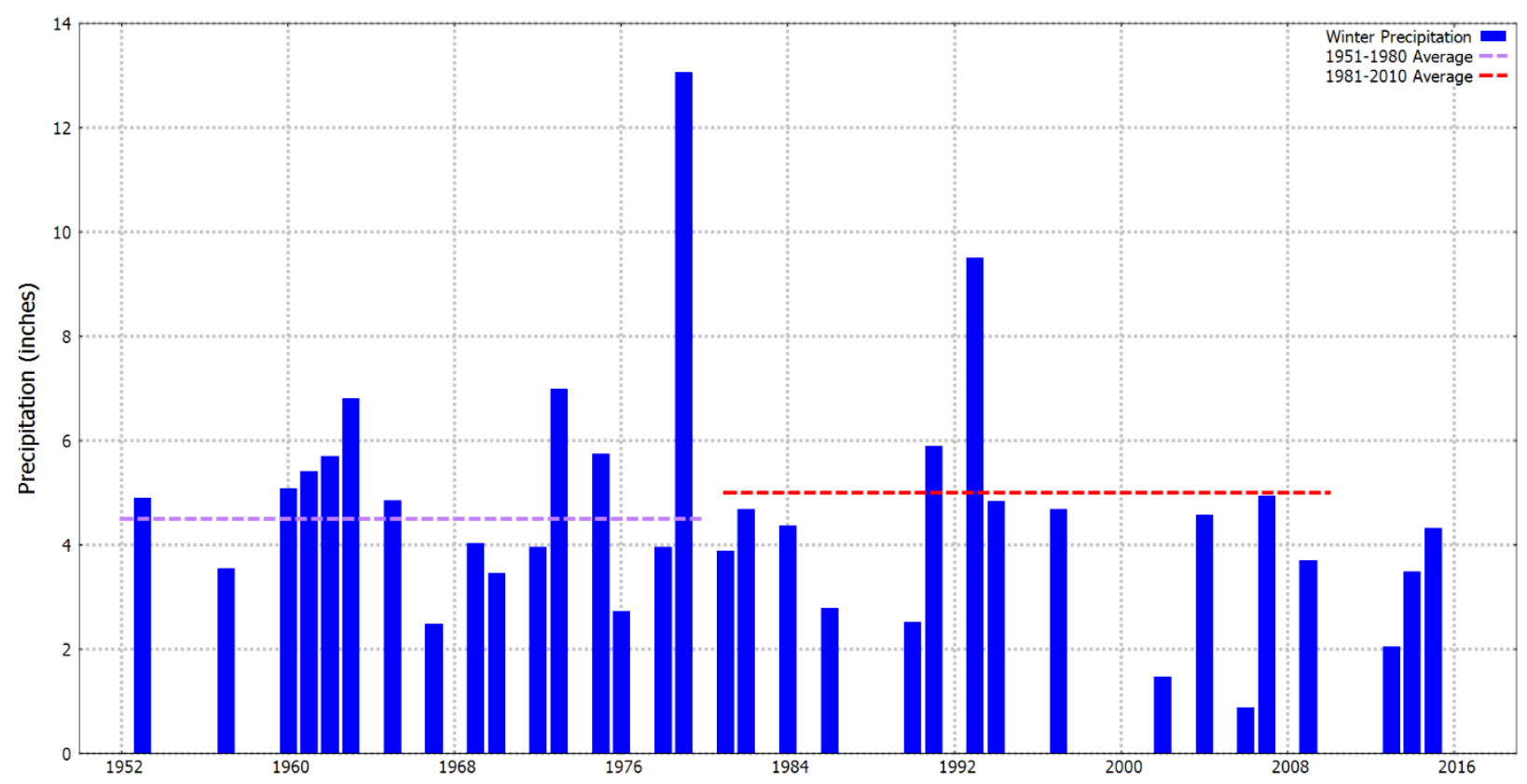

Figure 5-10: Los Alamos precipitation during El Niño/La Niña neutral years. The year represents the year of the end of the winter (e.g., 2016 is the winter of 20152016). 
The analysis of monsoon precipitation (June 15-September 30) following an El Niño or La Niña event is inconclusive. For the monsoon season following the 17 El Niño winters from 1981-2010, average precipitation was 9.66 inches compared with the 30 -year average of 9.31 inches. For the monsoon season following the seven La Niña winters between 1981 and 2010, average precipitation was 8.53 inches compared with the 30-year average of 9.31 inches. Gutzler (2000) identifies a negative correlation between Colorado spring snowpack and the Southwestern summer monsoon. A high spring season snowpack in Colorado produces a lower summer monsoon season precipitation total in the southwest. Other factors should be considered in future evaluations of monsoon variability in Los Alamos.

\subsection{Atmospheric Moisture}

The dew point temperature provides an estimate of the total amount of water vapor in the atmosphere at a specific pressure (or altitude). Relative humidity also provides an estimate of the water content of the atmosphere, but, as the name implies, it is a relative measurement. Relative humidity is a percentage of the total possible moisture that the atmosphere can hold. Table 5-5 and Figure 5-11 present monthly average dew point temperatures for the LANL mesa-top towers for 1994-2013. TA-49 dew point measurements are only available from 2000-2013. Table 5-6 and Figure 5-12 present the monthly average humidity for the LANL mesa-top towers.

Table 5-5: Monthly Average Dew Point Temperatures in ${ }^{\circ} \mathrm{F}$ (1994-2013)

\begin{tabular}{|l|c|c|c|c|}
\cline { 2 - 5 } \multicolumn{1}{c|}{} & TA-6 & TA-54 & TA-53 & TA-49 \\
\hline January & 13.9 & 15.0 & 15.2 & 14.2 \\
\hline February & 15.1 & 16.8 & 16.2 & 14.4 \\
\hline March & 17.7 & 18.8 & 18.2 & 16.2 \\
\hline April & 19.9 & 20.6 & 20.3 & 18.6 \\
\hline May & 25.2 & 25.6 & 25.5 & 23.8 \\
\hline June & 30.7 & 31.0 & 30.9 & 28.8 \\
\hline July & 44.5 & 45.5 & 45.1 & 44.4 \\
\hline August & 46.2 & 47.4 & 46.8 & 44.8 \\
\hline September & 38.6 & 39.8 & 39.0 & 36.7 \\
\hline October & 27.9 & 29.1 & 28.5 & 28.4 \\
\hline November & 19.1 & 20.3 & 19.9 & 19.0 \\
\hline December & 14.7 & 15.5 & 15.8 & 15.0 \\
\hline
\end{tabular}




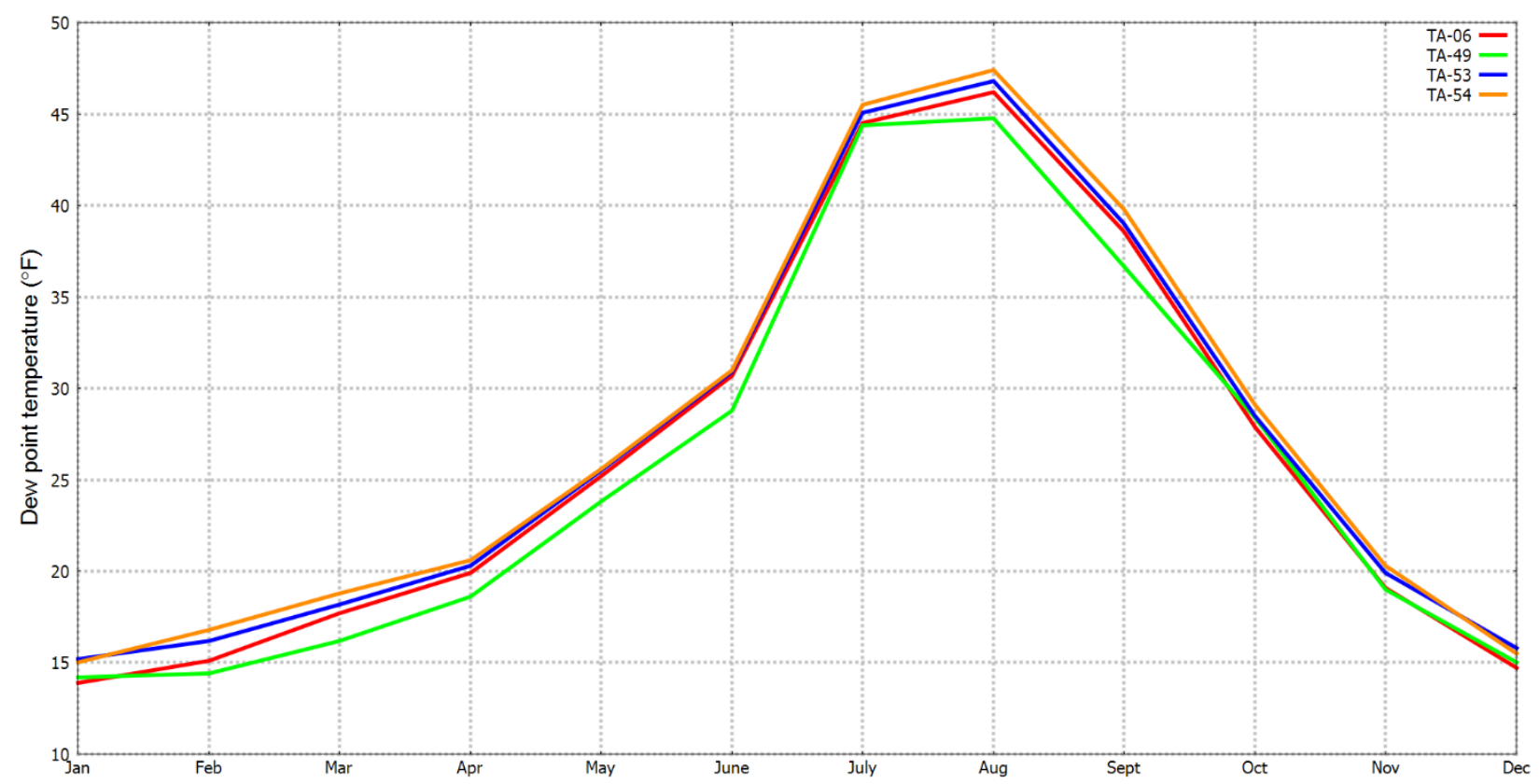

Figure 5-11: Monthly average dew point temperatures (1994-2013).

Table 5-6: Monthly Average Relative Humidity in Percent (1994-2013)

\begin{tabular}{|l|c|c|c|c|}
\cline { 2 - 5 } \multicolumn{1}{c|}{} & TA-6 & TA-54 & TA-53 & TA-49 \\
\hline January & 53.8 & 59.7 & 53.4 & 51.6 \\
\hline February & 51.9 & 54.4 & 50.6 & 48.9 \\
\hline March & 45.1 & 46.4 & 43 & 41.9 \\
\hline April & 40.1 & 40 & 37.8 & 37.3 \\
\hline May & 35.9 & 35.6 & 33.9 & 33.1 \\
\hline June & 32.8 & 32.5 & 30.9 & 31.3 \\
\hline July & 48.6 & 47.5 & 45.1 & 45.5 \\
\hline August & 54.2 & 53.5 & 50.6 & 50 \\
\hline September & 50.2 & 50.6 & 47 & 46 \\
\hline October & 48.9 & 51.9 & 46.7 & 45.9 \\
\hline November & 49.2 & 54.4 & 47.5 & 46.5 \\
\hline December & 55.6 & 61.7 & 55.2 & 53.8 \\
\hline
\end{tabular}




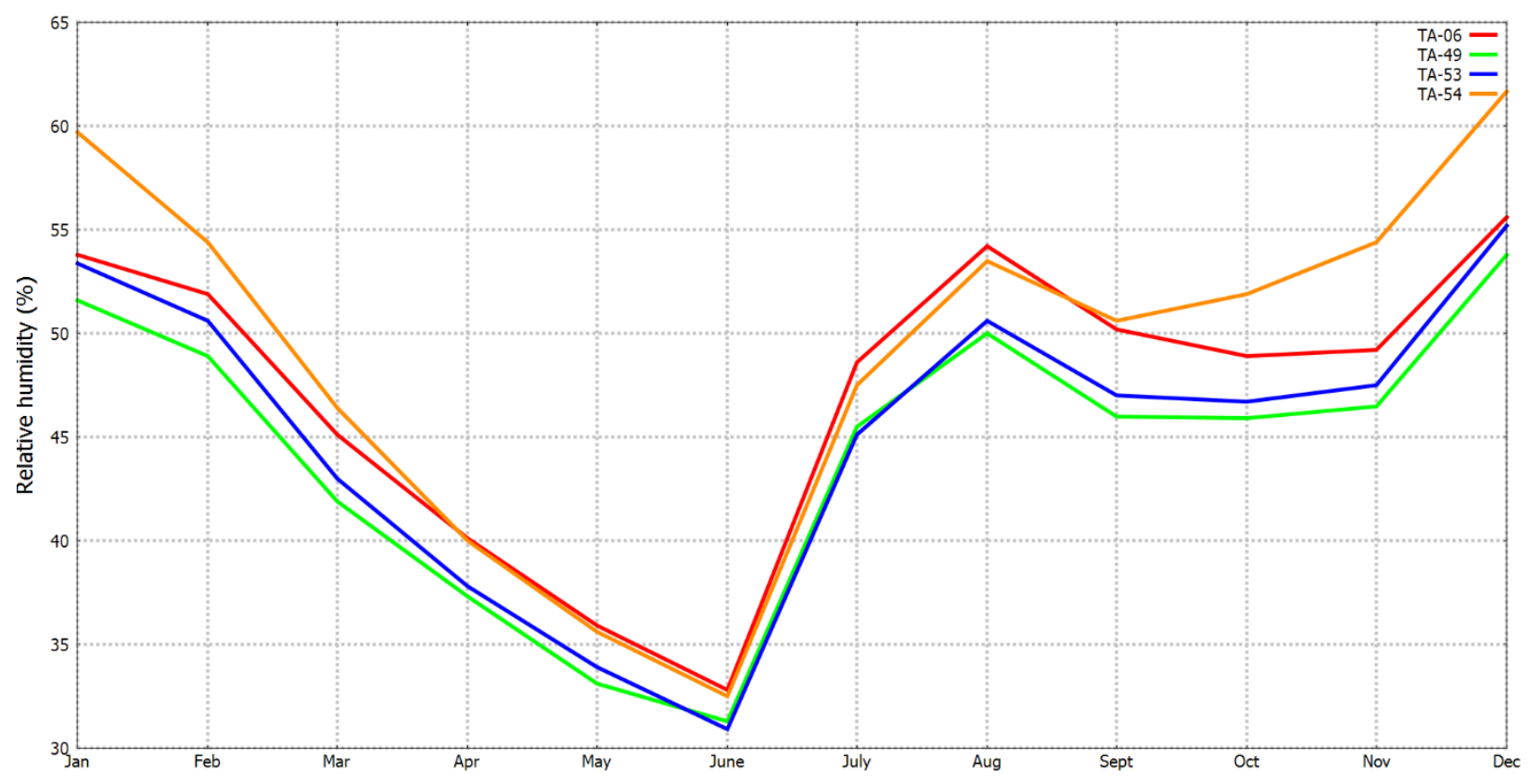

Figure 5-12: Monthly average relative humidity (1994-2013).

Los Alamos has a fairly dry atmosphere due to the large distance from the Gulf of Mexico (approximately 750 miles) and the Pacific Ocean (approximately 650 miles). The highest dew point temperatures occur in July and August, averaging over $40^{\circ} \mathrm{F}$, with September only slightly lower at $\sim 38^{\circ} \mathrm{F}$. These are the months of the summer monsoon season when Los Alamos records as much as $50 \%$ of the annual precipitation. Daily dew point temperatures can reach into the mid 60 's during the monsoon season. Lowest values occur in the winter and early spring, with average values between $15^{\circ} \mathrm{F}$ and $20^{\circ} \mathrm{F}$. Very low dew point temperatures of $10^{\circ} \mathrm{F}$ occur on many days of the winter.

Since relative humidity is dependent upon temperature, it has a near inverted annual distribution (Figure 5-12 and Table 5-6) when compared with the average dew point temperature (Figure 5-11). In warmer temperatures the atmosphere has a greater capacity to hold moisture, so the lowest average humidity is measured on the warmest days in May and June, before the summer monsoon season. Daily minimum relative humidity values can be less than $10 \%$ during the warm spring months. Relative humidity increases during July and August as a result of moisture brought into New Mexico by southerly winds from Mexico. Relative humidity increases during the winter months due to colder temperatures when the air can hold less water vapor. Relative humidity is measured above $90 \%$ on many winter nights.

\subsection{WIND}

\subsection{Average Wind Speed}

Los Alamos is a light wind site; annual average wind speeds on the mesas (measured at 12 meters) range from 6.2-7.4 mph. The highest average wind speeds occur during April, May, and June (Table 6-1 and Figure 6-1) when low-pressure systems deepen as they move east of the Rocky Mountains. The highest speeds, excluding Pajarito Mountain, are measured at TA-49 due to the more open nature of this tower location, with very few trees to cause less frictional drag on the wind. 
Wind speeds at TA-53 are also higher than average for mesa top locations, due to the very narrow aspect of the mesa where the tower is located. Wind speeds at the TA-53 location reflect the deep canyons to the north and south of the tower, where very little surface friction impacts the wind speed. Wind speeds within the canyons (TA-41 and TA-5 MDCN) are as much as 50\% lower than at mesa top locations because the canyon bottom locations are often protected from high mesa top wind speeds. This effect is greatest at TA-41, since Los Alamos Canyon is a much deeper and narrower canyon at the TA-41 tower location than Mortandad Canyon where the TA-5 MDCN tower is located. The TA-41 tower is protected because

- it is well below the mesa top ( 250 feet below mesa top level),

- the canyon bottom has a heavy tree cover which slows wind speeds due to friction, and

- mesa top peak wind speeds are often perpendicular to the WNW/ESE axes of the canyons, so that high mesa top wind speeds do not easily mix downward to the canyon bottom.

Average wind speeds at PJMT demonstrate a much different pattern than mesa top and canyon winds. PJMT winds (measured at 10,000 feet) represent winds produced by the large-scale synoptic weather patterns and are not produced by the local topographic influences on wind found on the mesas and within canyons. There are very little surface friction impacts at this height and very little impact from surface heating. (This is in part due to the height of the wind speed measurement at 36 meters, which is much greater than the 12-meter measurement height of the mesa and canyon towers.) The highest average wind speeds are observed in the spring and winter, similar to the mesa top winds, but there is a distinct wind speed minimum during the summer months. This reflects the monsoon circulation that affects the southwestern United States during the summertime. The midlatitude jet stream moves north and is replaced by the Four Corners high-pressure system (Adams and Comrie 1997) characterized by lower wind speeds at 10,000 feet, the height of Pajarito Mountain.

Table 6-1: Monthly Average Wind Speeds at 12 meters AGL in mph

\begin{tabular}{|l|c|c|c|c|c|c|c|}
\cline { 2 - 8 } \multicolumn{1}{c|}{} & TA-6 & TA-54 & TA-53 & TA-49 & TA-5 MDCN $^{*}$ & TA-41 $^{\text {PJMT* }}$ \\
\hline January & 5.1 & 5.3 & 5.4 & 6.0 & 3.7 & 3.1 & 17.0 \\
\hline February & 5.9 & 6.2 & 6.3 & 6.9 & 4.1 & 3.3 & 17.4 \\
\hline March & 6.8 & 7.0 & 7.2 & 7.9 & 4.8 & 3.8 & 16.8 \\
\hline April & 7.9 & 8.1 & 8.4 & 9.1 & 5.5 & 4.3 & 18.0 \\
\hline May & 7.7 & 8.2 & 8.5 & 9.1 & 5.4 & 4.3 & 16.8 \\
\hline June & 7.4 & 7.9 & 8.2 & 8.7 & 5.2 & 4.0 & 15.6 \\
\hline July & 5.7 & 6.6 & 6.9 & 7.5 & 4.4 & 3.2 & 11.3 \\
\hline August & 5.4 & 6.2 & 6.6 & 6.9 & 4.1 & 3.1 & 11.1 \\
\hline September & 5.8 & 6.4 & 6.7 & 7.2 & 4.2 & 3.2 & 13.8 \\
\hline October & 5.8 & 6.2 & 6.5 & 7.0 & 4.2 & 3.2 & 14.9 \\
\hline November & 5.4 & 5.7 & 5.8 & 6.5 & 4.0 & 3.2 & 15.9 \\
\hline December & 5.0 & 5.4 & 5.4 & 6.0 & 3.7 & 2.9 & 17.1 \\
\hline Annual & 6.2 & 6.6 & 6.8 & 7.4 & 4.4 & 3.5 & 15.5 \\
\hline
\end{tabular}

*TA-5 MDCN measurement height is 10 meters AGL and PJMT measurement height is 36 meters AGL. 


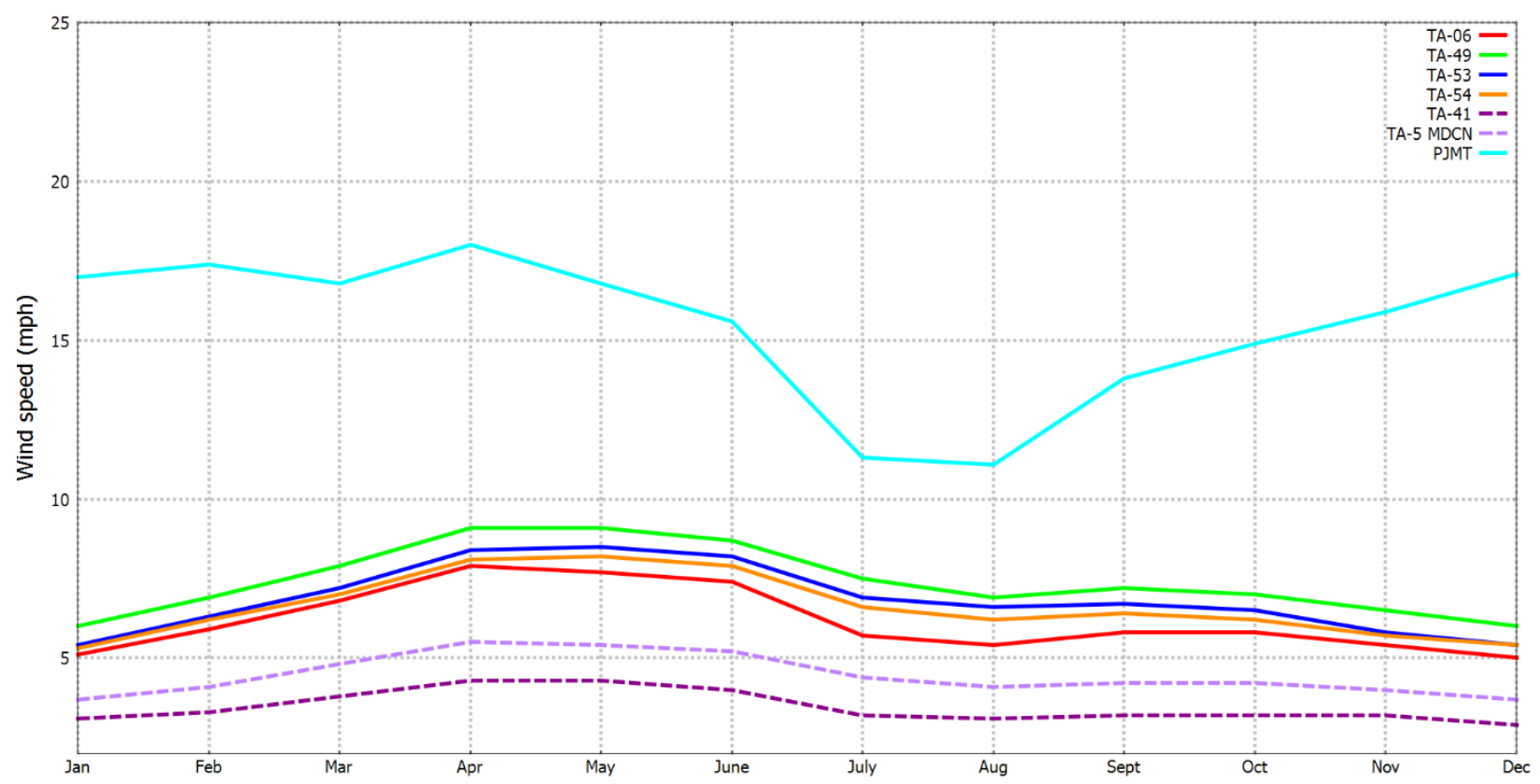

Figure 6-1: Monthly average wind speeds at 12 meters AGL for mesa-top and canyon towers. PJMT is measured at 36 meters AGL.

\subsection{Peak Gusts}

Average peak gust wind speeds range from 20-33 mph across the Pajarito Plateau (Table 6-2 and Figure 6-2). Average peak gusts are much higher at PJMT, reaching an average of $43 \mathrm{mph}$ in the spring. Peak gusts at each tower site follow a similar pattern to the average wind speeds. Highest average peak gusts occur in the spring and winter.

Table 6-2: Monthly Average Peak Wind Gusts at 12 meters AGL in mph

\begin{tabular}{|l|c|c|c|c|c|}
\cline { 2 - 6 } \multicolumn{1}{c|}{} & TA-6 & TA-49 & TA-53 & TA-54 & PJMT* $^{*}$ \\
\hline January & 20.9 & 21.2 & 21.8 & 19.9 & 38.4 \\
\hline February & 24.4 & 25.0 & 24.8 & 23.1 & 40.8 \\
\hline March & 26.8 & 28.1 & 28.0 & 26.7 & 39.5 \\
\hline April & 31.3 & 33.1 & 32.7 & 31.5 & 42.8 \\
\hline May & 30.4 & 32.6 & 32.8 & 31.8 & 40.4 \\
\hline June & 29.8 & 32.0 & 32.4 & 31.6 & 38.3 \\
\hline July & 25.4 & 27.4 & 29.0 & 28.0 & 35.0 \\
\hline August & 23.7 & 26.4 & 27.3 & 26.2 & 29.7 \\
\hline September & 23.8 & 25.5 & 25.9 & 24.9 & 33.4 \\
\hline October & 23.2 & 24.5 & 24.5 & 23.3 & 35.7 \\
\hline November & 21.3 & 21.9 & 22.1 & 20.6 & 36.6 \\
\hline December & 20.2 & 21.0 & 21.1 & 19.3 & 39.2 \\
\hline Annual & 25.1 & 26.6 & 26.9 & 25.6 & 37.5 \\
\hline
\end{tabular}

${ }^{*} \mathrm{PJMT}$ is measured at 36 meters AGL. 


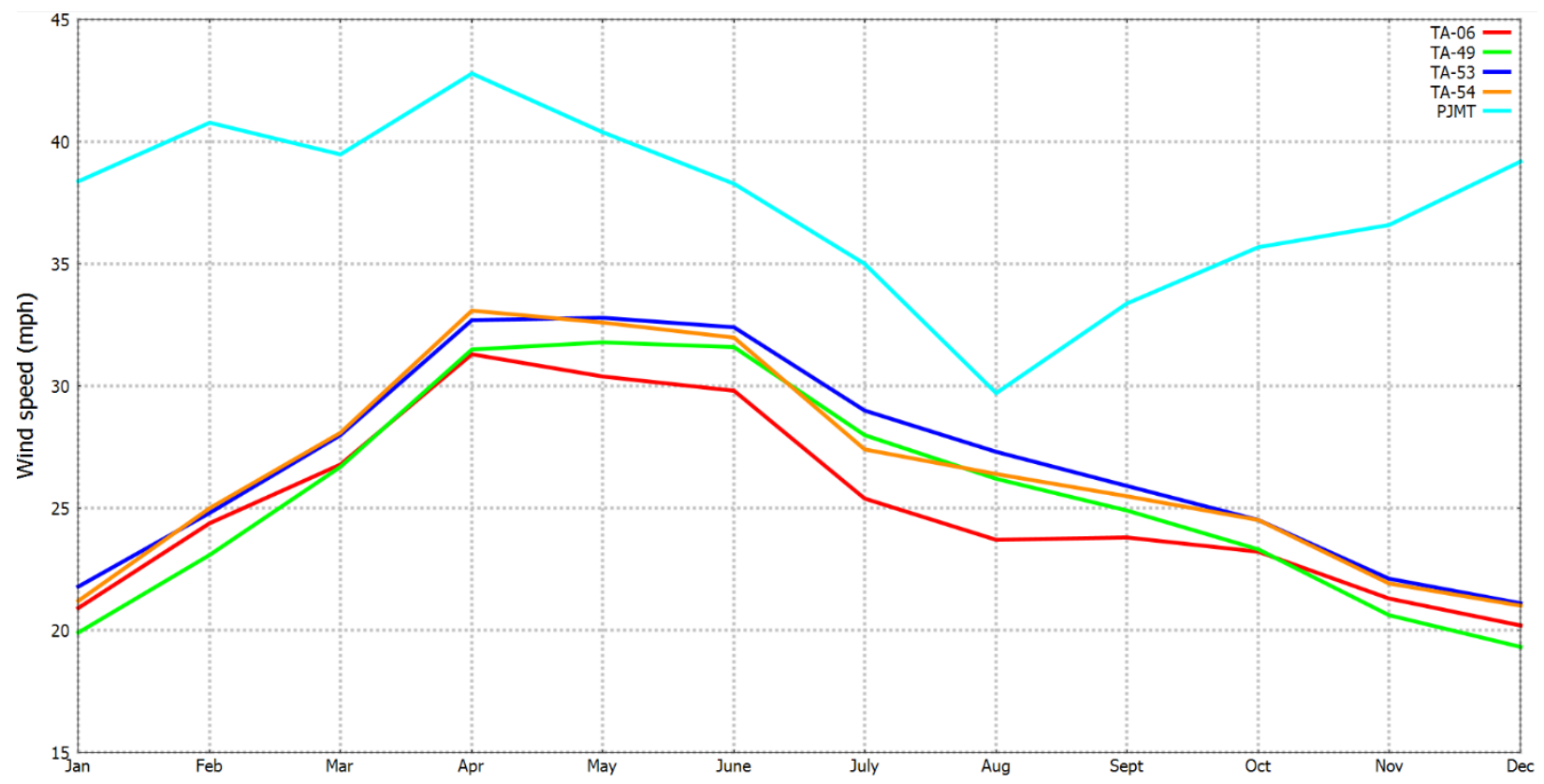

Figure 6-2: Monthly average peak wind gusts at 12 meters AGL. PJMT is measured at 36 meters AGL.

\subsection{Wind Direction}

Daytime winds (sunrise to sunset) and nighttime winds (sunset to sunrise) are shown in the form of wind roses in Figures 6-3 and 6-4. The wind roses are based on 15-minute-averaged wind observations for 2007 at the four mesa-top stations, PJMT, and the canyon stations. Wind roses depict the percentage of time that wind blows from each of 16 direction bins and the distribution of wind speed. For example, the TA-6 wind rose during the day can be interpreted as measuring winds directly from the south over $12 \%$ of the time. The wind speeds range from 2.5 to 5 meters/second under $8 \%$ of the time, 5 to 7.5 meters/second over $2 \%$ of the time, and exceed 7.5 meters/second only a fraction of $1 \%$ of the time. Although not shown here, wind roses from different years are almost identical in terms of the distribution of wind directions, indicating that wind patterns are constant when averaged over a year. 

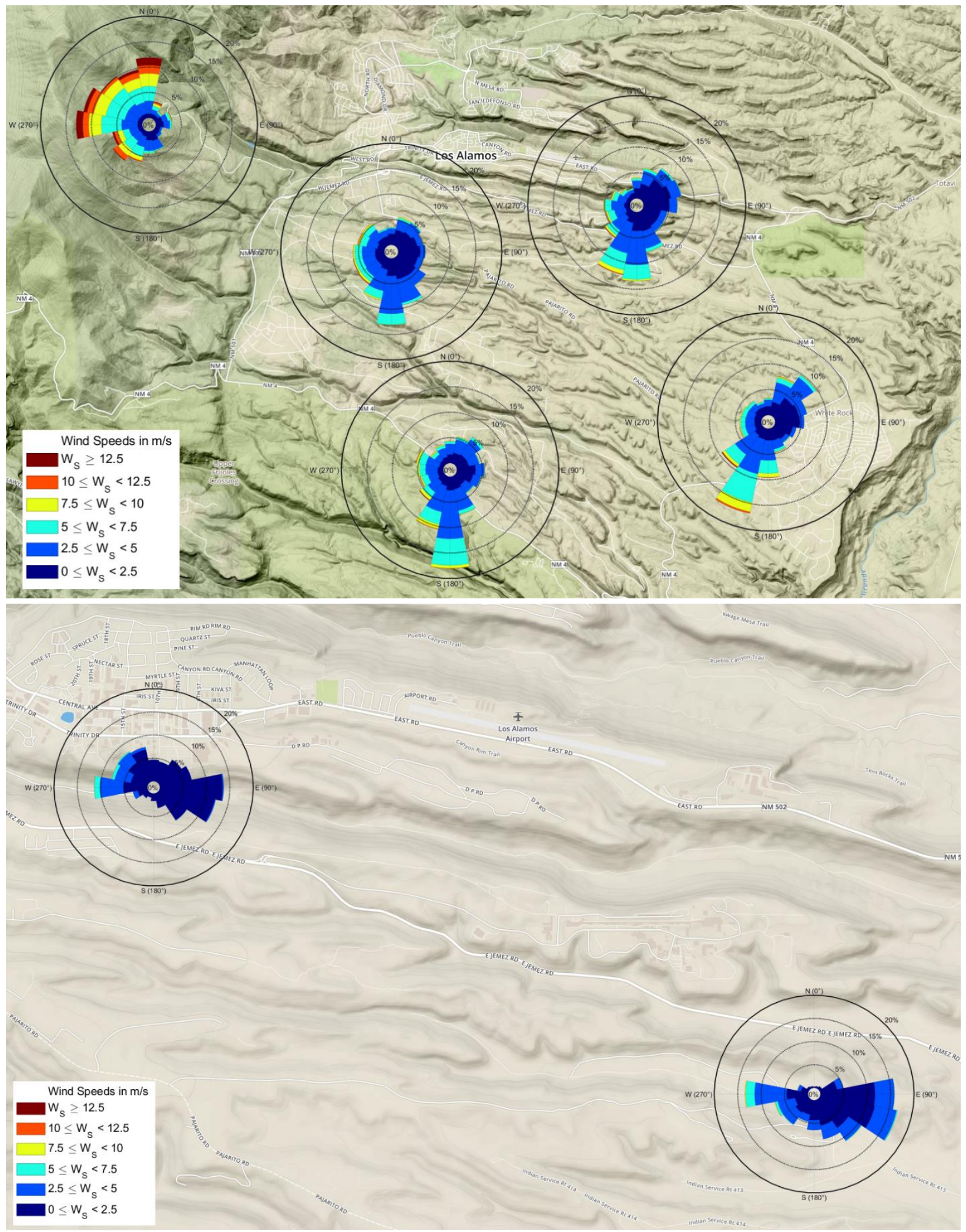

Figure 6-3: Daytime wind roses during 2007. 

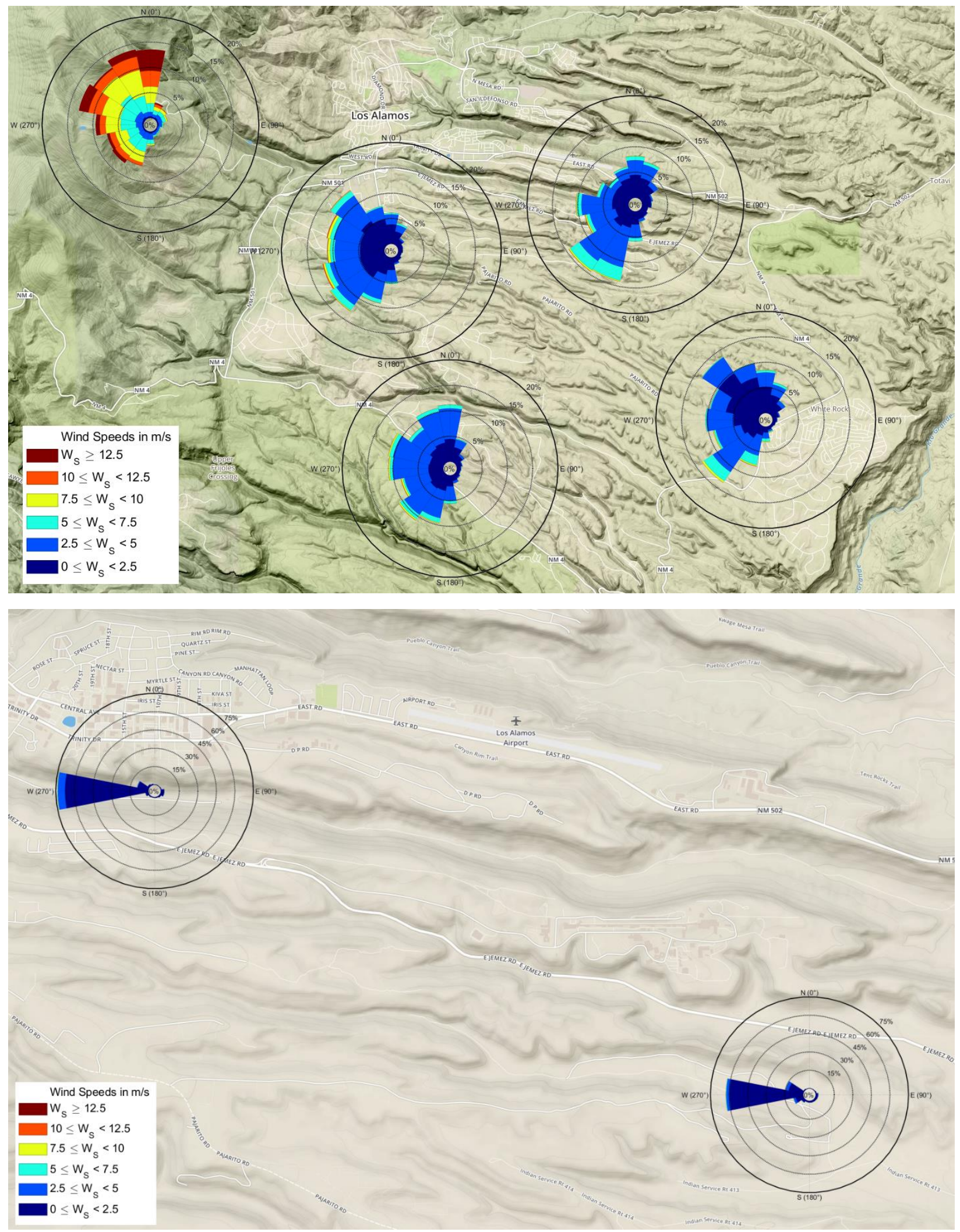

Figure 6-4: Nighttime wind roses during 2007. 


\subsection{PAN EVAPORATION}

Average evaporation rates are used in the designing of LANL evaporation ponds and basins. However, evaporation is not measured at LANL. Since evaporation is a function of temperature, humidity, rainfall, solar radiation, and wind speed, the closest stations that can provide insight into evaporation rates at Los Alamos are at Abiquiu Dam and El Vado Dam. These data are collected by the Army Corps of Engineers and are made available through the National Centers for Environmental Information (formerly known as the National Climatic Data Center) website (NOAA 2016b). Abiquiu Dam is at 6260 feet elevation, 30 miles north of LANL, and El Vado Dam is at 6900 feet elevation, 60 miles north of Los Alamos. Both of these stations have long-term records (50 and 80 years, respectively), and are used for managing the reservoirs behind the dams.

Evaporation rates are measured in a Class A Pan, a cylinder with a diameter of 47.5 inches that has a depth of 10 inches. Evaporation is measured daily as the depth of water (in inches) evaporates from the pan. The measurement day begins with the pan filled to exactly 2 inches ( 5 centimeters) from the pan top. At the end of 24 hours, the amount of water to refill the pan to exactly 2 inches from its top is measured. If precipitation occurs in the 24-hour period, it is taken into account in calculating the evaporation. Pan evaporation is typically measured between March and October, when the water in the pan will not freeze.

The 1981-2010 average pan evaporation was calculated using daily measured evaporation values. The annual value at Abiquiu Dam is 59 inches and at El Vado Dam it is 47 inches. The value for Abiquiu Dam is similar to an expected value for White Rock since the elevation and summertime temperatures are very similar. The evaporation rate for Los Alamos would be expected to be higher than at El Vado Dam. El Vado Dam has a similar elevation to Los Alamos but the summertime temperatures are slightly cooler and the precipitation is greater than in Los Alamos. The monthly distribution of pan evaporation totals for Abiquiu Dam and El Vado Dam are presented in Figure 7-1. Highest monthly totals occur during the warmest months of the year.

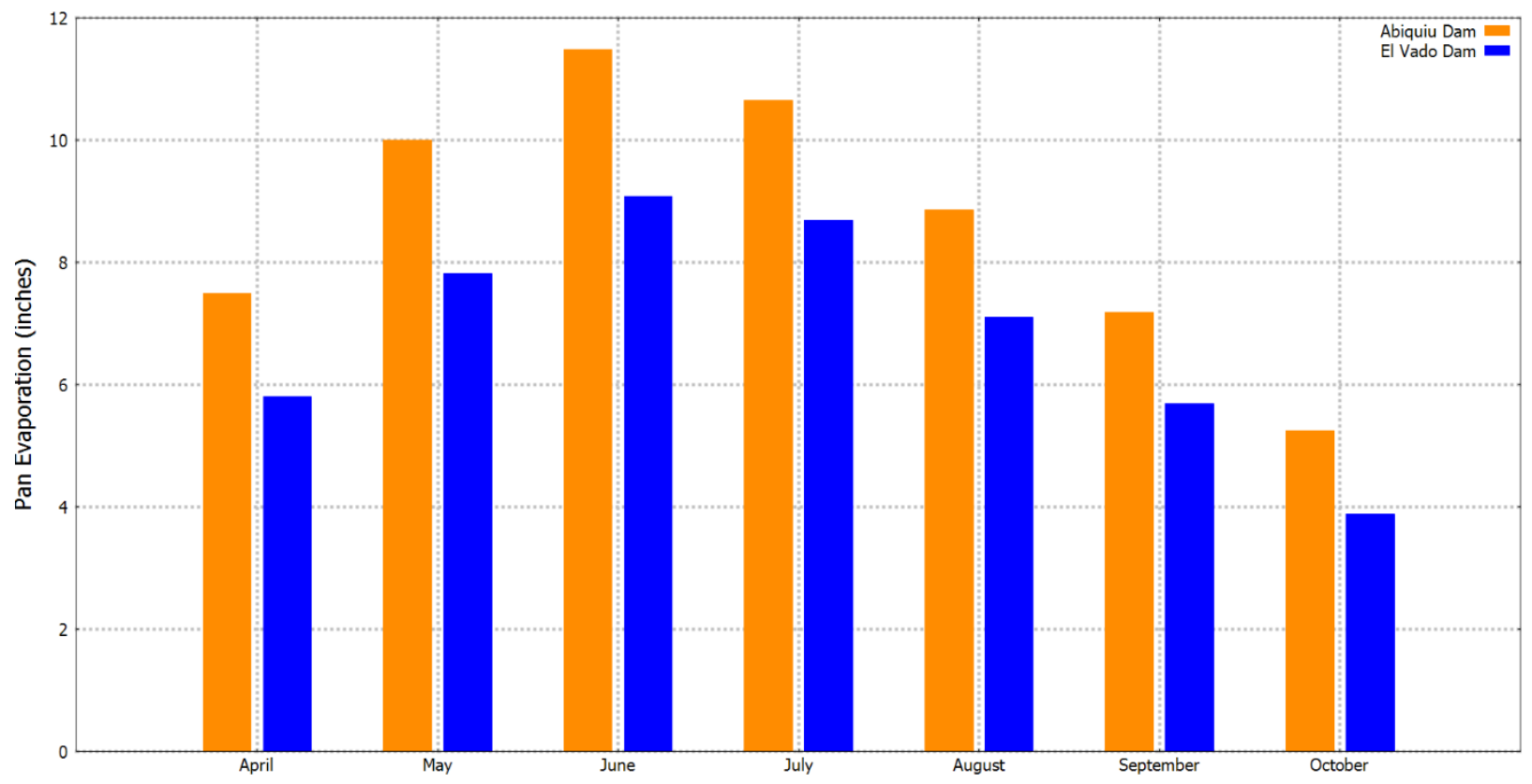

Figure 7-1: Monthly average pan evaporation at Abiquiu Dam and El Vado Dam (1981-2010). 


\subsection{INSOLATION}

LANL measures the radiation components of the earth's surface energy budget (Figure 8-1) at ground level. LANL measures incoming and reflected solar radiation in the visible range of light, from 0.3-2.8 micrometers. Longwave radiation emitted by the atmosphere and the surface of the earth is measured in the infrared range from 3.5-50 micrometers. Incoming longwave radiation represents an integrated temperature of the atmosphere above the monitoring location whereas outgoing longwave radiation represents the temperature of the surface of the earth. Incoming solar radiation is measured at all LANL tower locations for use in LANL solar energy projects. These data can also be used in atmospheric dispersion calculations. Reflected solar radiation and longwave radiation (incoming and outgoing) are also measured at TA-6 and TA-54, and along with incoming solar radiation, can be used in calculating surface energy budgets and estimating evaporation.

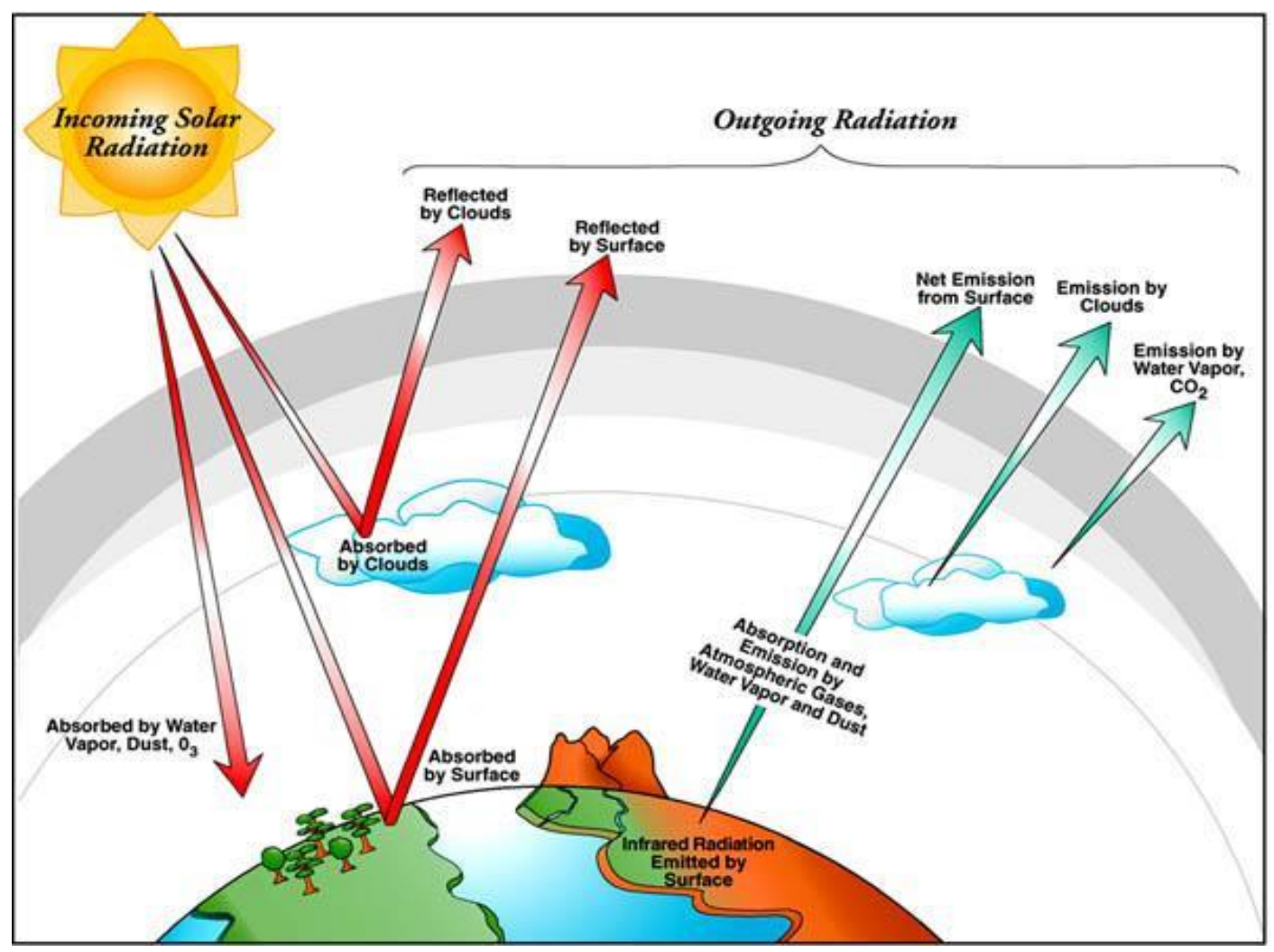

Figure 8-1: Conceptual diagram of incoming solar radiation and outgoing longwave (infrared) radiation (Youngman 2016).

Monthly average incoming solar radiation at all towers is presented in Table 8-1 and Figure 8-2. All of the towers have very similar values, except for TA-41. Los Alamos Canyon, the location of the TA-41 tower, is a very narrow (100 feet) and deep (300 feet) canyon where incoming solar radiation is partially blocked by the canyon walls throughout the year. Although the TA-5 MDCN tower is also located in the bottom of a canyon, Mortandad Canyon is very wide ( 700 feet) and fairly shallow ( $\sim 70$ feet deep) at the tower location, so incoming solar radiation is not significantly blocked by canyon walls. TA-54 measures slightly greater amounts of incoming solar radiation in the summer due to less rainfall/cloudiness at this location compared with other tower locations. 
Table 8-1: Monthly Average Incoming Solar Radiation in MJ/m² (1994-2013)

\begin{tabular}{|l|c|c|c|c|c|c|}
\cline { 2 - 7 } \multicolumn{1}{c|}{} & TA-6 & TA-54 & TA-49 & TA-53 & TA-41 & $\begin{array}{c}\text { TA-5 } \\
\text { MDCN }\end{array}$ \\
\hline January & 11.9 & 12.1 & 12.0 & 11.7 & 2.7 & 12.3 \\
\hline February & 15.1 & 15.3 & 15.2 & 14.9 & 8.4 & 14.9 \\
\hline March & 19.6 & 20.1 & 19.9 & 19.4 & 17.4 & 19.7 \\
\hline April & 23.3 & 24.0 & 23.6 & 23.1 & 21.3 & 23.5 \\
\hline May & 26.2 & 27.3 & 26.9 & 26.3 & 23.6 & 26.1 \\
\hline June & 27.6 & 28.7 & 28.3 & 27.9 & 24.5 & 27.3 \\
\hline July & 23.6 & 25.0 & 24.5 & 24.1 & 20.3 & 24.0 \\
\hline August & 21.7 & 23.1 & 22.6 & 22.2 & 18.8 & 21.9 \\
\hline September & 20.2 & 20.9 & 20.5 & 20.1 & 17.8 & 20.5 \\
\hline October & 16.5 & 16.9 & 16.8 & 16.4 & 11.3 & 16.5 \\
\hline November & 12.6 & 12.9 & 12.7 & 12.5 & 3.7 & 13.0 \\
\hline December & 10.6 & 10.7 & 10.6 & 10.4 & 2.0 & 10.4 \\
\hline
\end{tabular}

${ }^{*} \mathrm{MJ} / \mathrm{m}^{2}=$ megajoule per square meter.

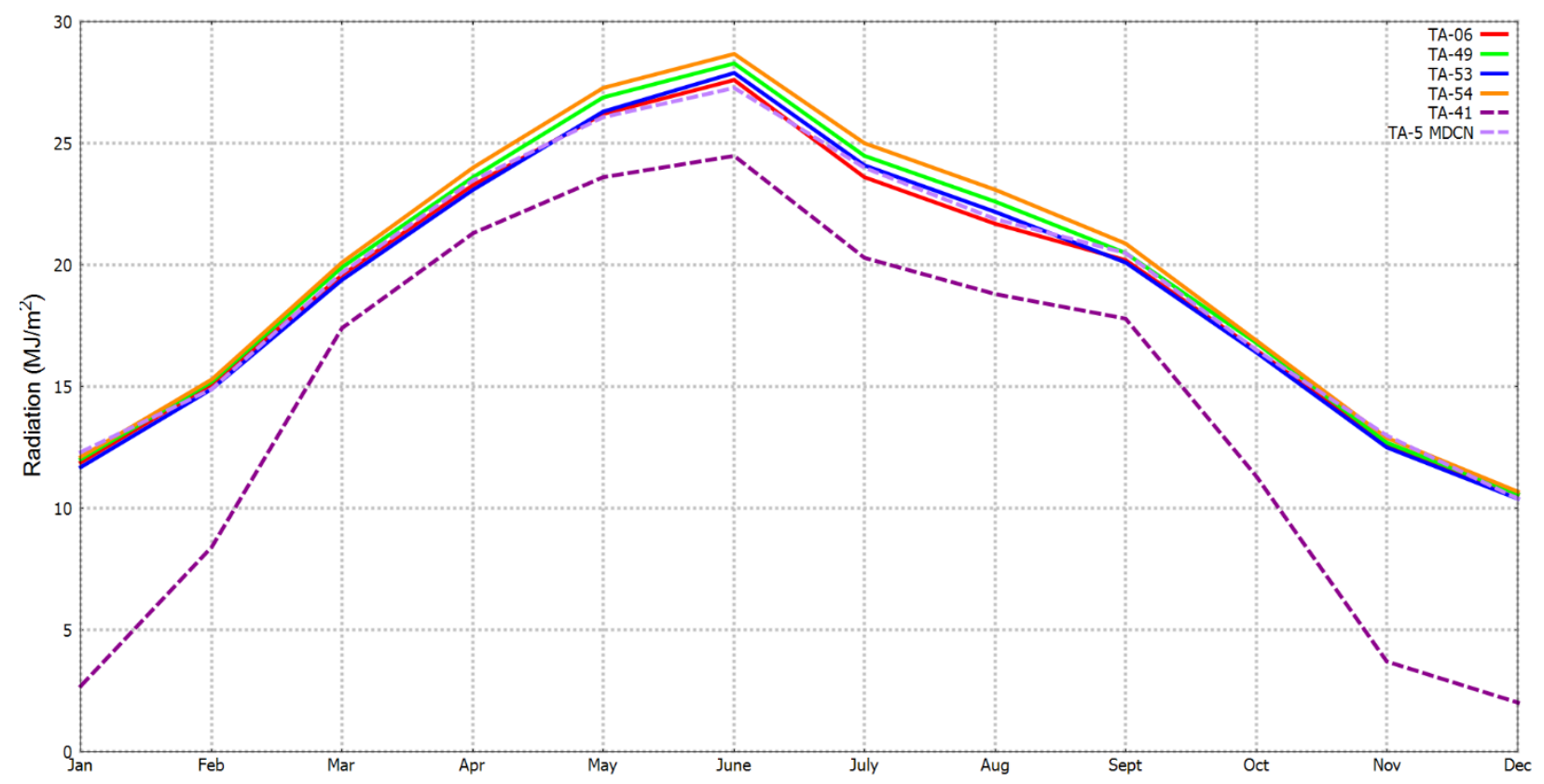

Figure 8-2: Monthly average incoming solar radiation (1994-2013).

The albedo of a surface (a measure of how much light that hits the surface is reflected without being absorbed; the "whiteness" of a surface) is calculated as the ratio of the reflected solar radiation/incoming solar radiation. Bare rocks and soils are more reflective of sunlight than green grasses and trees. The albedo at TA-54, 0.26, is greater than the albedo at TA-6, 0.22, due to the greater prevalence of bare and rocky soils at TA-54, in comparison with the greater amounts of green grasses and trees at TA-6. 
The atmosphere and the surface both radiate energy in the long wavelengths, so the energy budget at the surface of the earth is measured as the sum of incoming shortwave and longwave radiation minus the reflected shortwave and outgoing longwave radiation. The monthly average for each radiation measurement at TA-6 and TA-54 are presented in Figures 8-3 and 8-4.

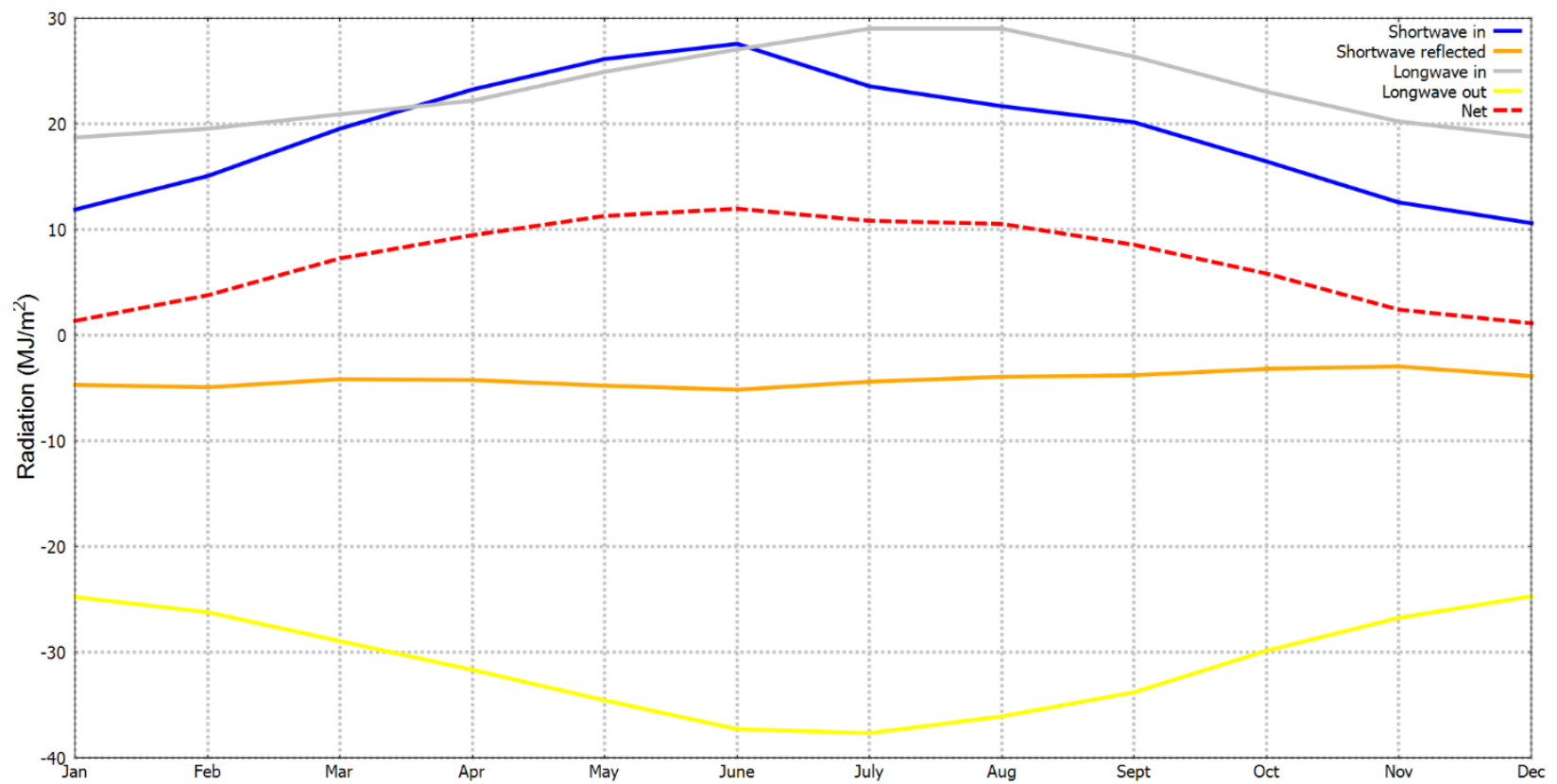

Figure 8-3: $\quad$ Monthly average surface radiation energy balance at TA-6 (1994-2013).

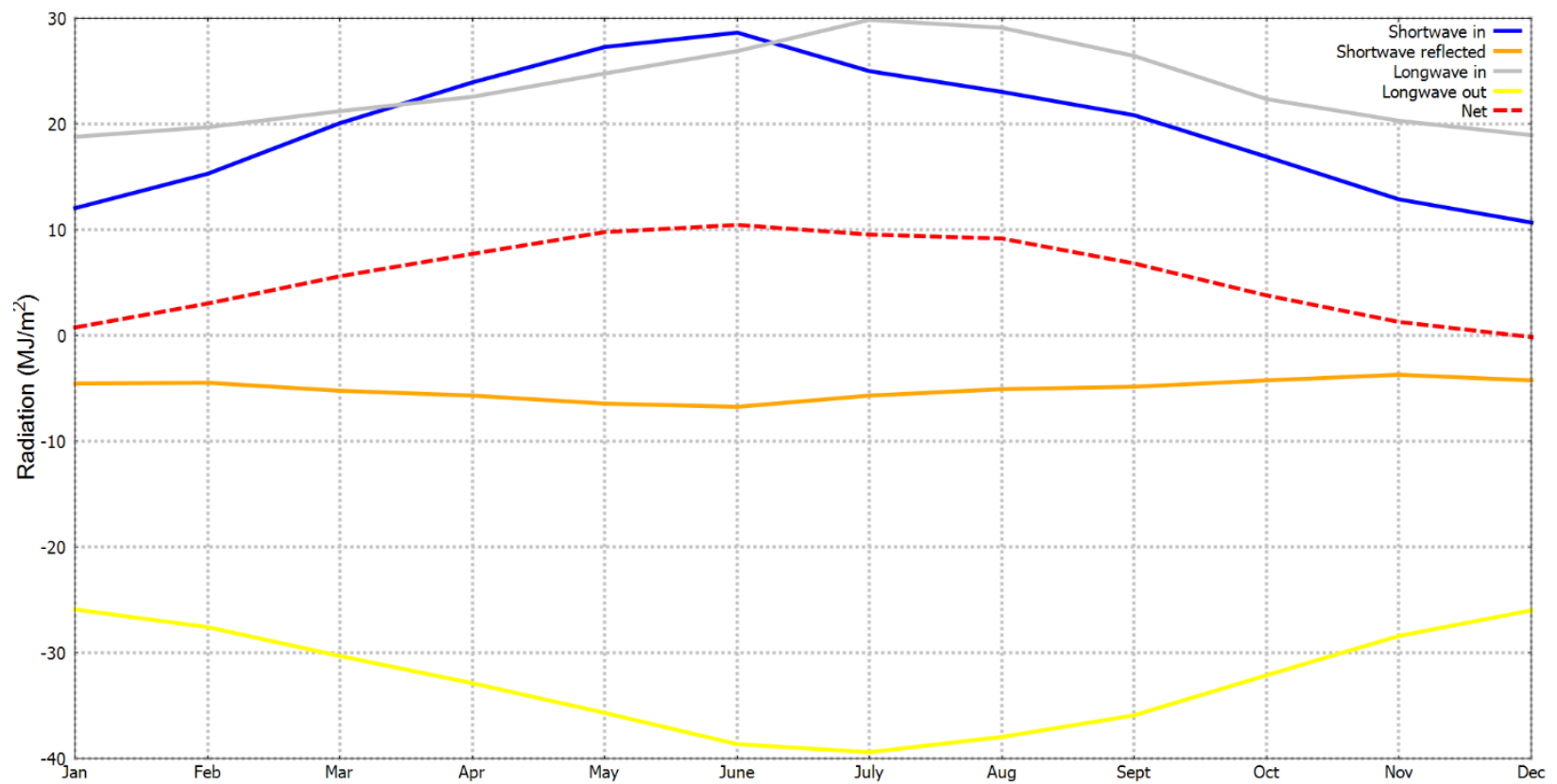

Figure 8-4: $\quad$ Monthly average surface radiation energy balance at TA-54 (1994-2013).

The maximum reflected shortwave radiation follows the pattern of incoming solar radiation, and peaks in June at both TA-6 and TA-54. Longwave radiation is a function of the temperature of the atmosphere or the ground surface and peaks in July as the maximum temperature of the atmosphere 
and the surface lags behind the solar maximum. The maximum net positive radiative energy at the surface is measured in June with the net energy approaching zero in the colder winter months.

\subsection{PRESSURE}

The United States Standard Atmosphere is an atmospheric model of how the pressure, temperature, and density of the Earth's atmosphere changes over a wide range of altitudes or elevations. The standard atmospheric pressure is the weight of a column of air from sea level to the top of the atmosphere. At sea level, this pressure is 29.92 inches of mercury or 1013.3 millibars $(\mathrm{mb})$. As the surface of the earth rises with terrain, there is less atmosphere above the ground, so the pressure at the elevated surface decreases. The standard atmospheric pressure is about 22.73 inches of mercury $(770.0 \mathrm{mb})$ at the TA-6 elevation, 7424 feet above sea level. The air pressure at Los Alamos is $~ 76 \%$ of sea-level pressure. Pressure measurements are available for Los Alamos beginning in 1979 and for White Rock in 1992. Long-term averages are calculated for 1994-2013 following the convention for other meteorology parameters across the Laboratory.

Monthly mean atmospheric pressure is shown in Table 9-1 and Figure 9-1 for TA-6 and TA-54. Because TA-54 is about 900 feet lower than TA-6, the average pressures are about 25 mb higher than at TA-6. There is an annual cycle, with a summer maximum and a spring minimum. The spring minimum is caused by frequent midlatitude low-pressure storms. The summertime maximum is caused by the upper-atmosphere westerlies moving to the north and the subtropical high-pressure systems moving northward into the southern United States. Variations from the mean are greatest in the spring and winter seasons and least during the summer.

\section{Table 9-1: Monthly Average Pressure at TA-6 and TA-54 in mb (1994-2013)}

\begin{tabular}{|l|c|c|}
\cline { 2 - 3 } \multicolumn{1}{c|}{} & TA-6 & TA-54 \\
\hline January & 774.4 & 800.9 \\
\hline February & 773.2 & 799.4 \\
\hline March & 773.1 & 799.1 \\
\hline April & 772.8 & 798.5 \\
\hline May & 774.8 & 800.2 \\
\hline June & 777.0 & 802.0 \\
\hline July & 779.9 & 804.8 \\
\hline August & 780.1 & 805.1 \\
\hline September & 778.8 & 804.0 \\
\hline October & 776.8 & 802.5 \\
\hline November & 776.2 & 802.3 \\
\hline December & 774.4 & 800.9 \\
\hline
\end{tabular}




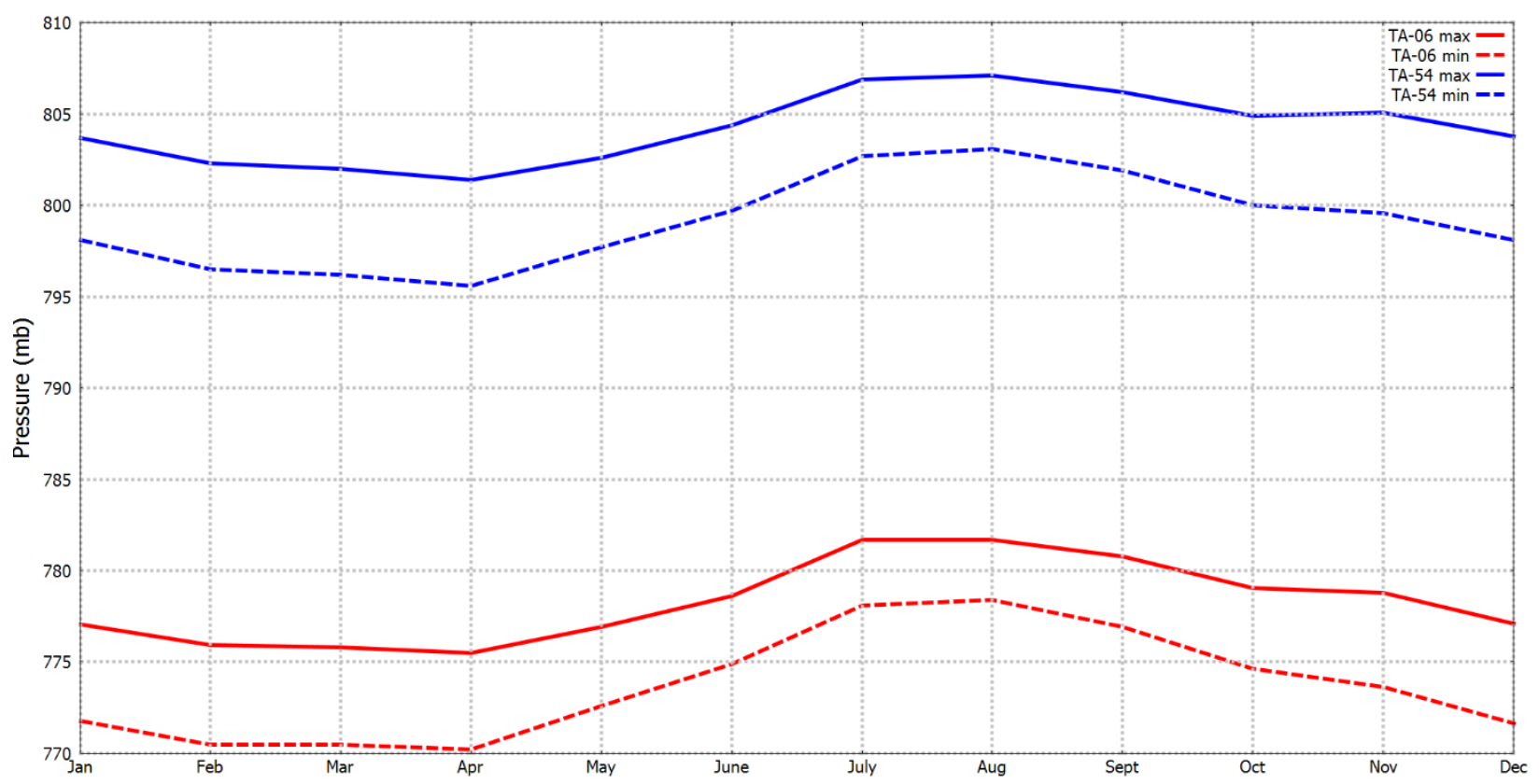

Figure 9-1: Monthly average maximum and minimum pressure at TA-6 and TA-54 (1994-2013).

Even though the average pressure is highest during the summer, the highest 15-minute pressure measurements tend to occur in the wintertime. High wintertime pressure readings can result from cold, arctic air high-pressure systems pushing their way into New Mexico from the Great Plains; the cold air is dense and so produces high pressure values. The highest 15 minute pressure measured at TA-6 is $792 \mathrm{mb}$; the highest 15 minute pressure measured at TA-54 is $819 \mathrm{mb}$. The lowest pressures recorded at TA-6 and TA-54 are $739 \mathrm{mb}$ and $771 \mathrm{mb}$, respectively.

In addition to an annual cycle of pressure, there is a semi-diurnal (12 hour) cycle in pressure measurements, caused by the heating of the upper atmosphere by the sun. Hourly average pressure at TA-6 and TA-54 (minus $25 \mathrm{mb}$ ) demonstrate minimum values at 4 AM and 4 PM and maximum values at $9 \mathrm{AM}$ and midnight (Figure 9-2). 


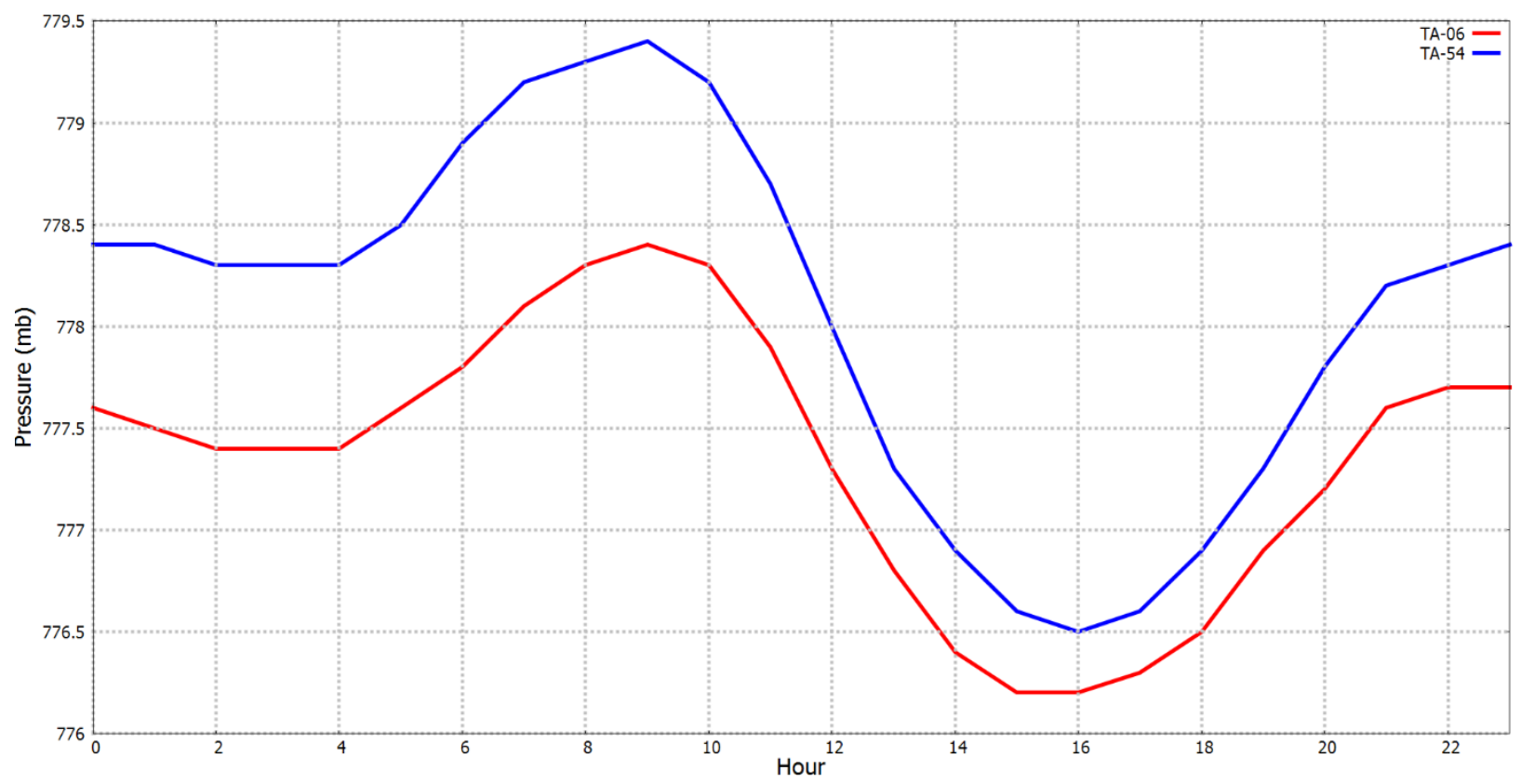

Figure 9-2: Hourly average pressure at TA-6 and TA-54 (minus $25 \mathrm{mb}$ ) during 2013.

\section{CLIMATE TRENDS}

In the last half of the twentieth century, greenhouse gas emissions from human activity have begun to make a long-term impact on the Earth's climate (IPCC 2013). The average combined land and ocean surface temperature has increased by $0.85^{\circ} \mathrm{C}$ from $1880-2012$ and the global mean sea level rose by 0.19 meters from 1901-2010 (IPCC 2013). For the Southwest United States, temperatures from 2001-2010 were nearly $2^{\circ} \mathrm{F}$ above normal (Garfin et al. 2013). Temperatures are predicted to rise over the next century, snowfall is expected to decrease (due in part to rising temperatures), and extended droughts (with resulting wildland fires) are expected to be more severe (Melillo et al. 2014). In this section, the Los Alamos data are evaluated to determine what climate changes are being measured in Los Alamos. Other LANL data will be available in the future to further characterize climate changes in Los Alamos, including stormwater runoff and locations of bird species with altitude.

\subsection{Temperature}

Figure 10-1 shows the historical record of temperatures in Los Alamos from 1924-2015. The annual average temperature is the average of the daily high and low temperatures averaged over the year. One-year averages are shown in green in Figure 10-1. To aid in showing longer-term trends, the 5-year running mean (black) is also shown. The 5-year average shows the warm spell during the past 15 years is almost as extreme as the warm spell during the early-to-mid 1950s and is longer-lived. 


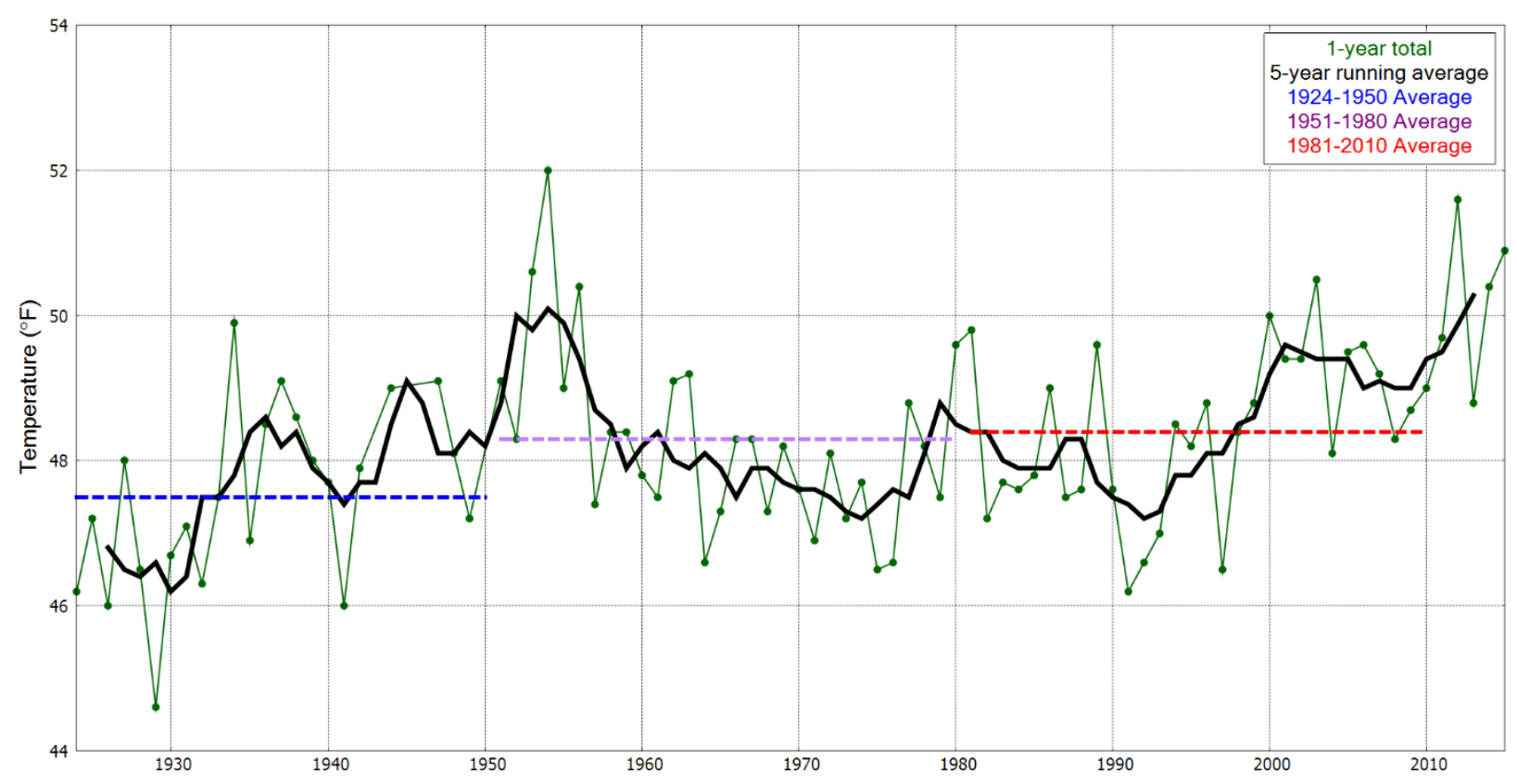

Figure 10-1: Temperature history for Los Alamos (1924-2015).

The average temperatures per decade, along with two times the standard error, are plotted in Figure 10-2 with the annual average temperatures for 2011-2015. Ninety-five percent of the annual average temperatures during each decade are found within the error bars. During the decades between 1960 and 2000, the annual average temperatures in Los Alamos vary only slightly from $48^{\circ} \mathrm{F}$. During the 2001-2010 decade, the annual average temperature increased to above $49^{\circ} \mathrm{F}$; this value can be considered a statistically significantly higher value than previous decades. The annual average temperatures from 2011-2015 continue to demonstrate a warmer climate for Los Alamos. This is consistent with predictions for a warming climate in the southwestern United States (IPCC 2013).

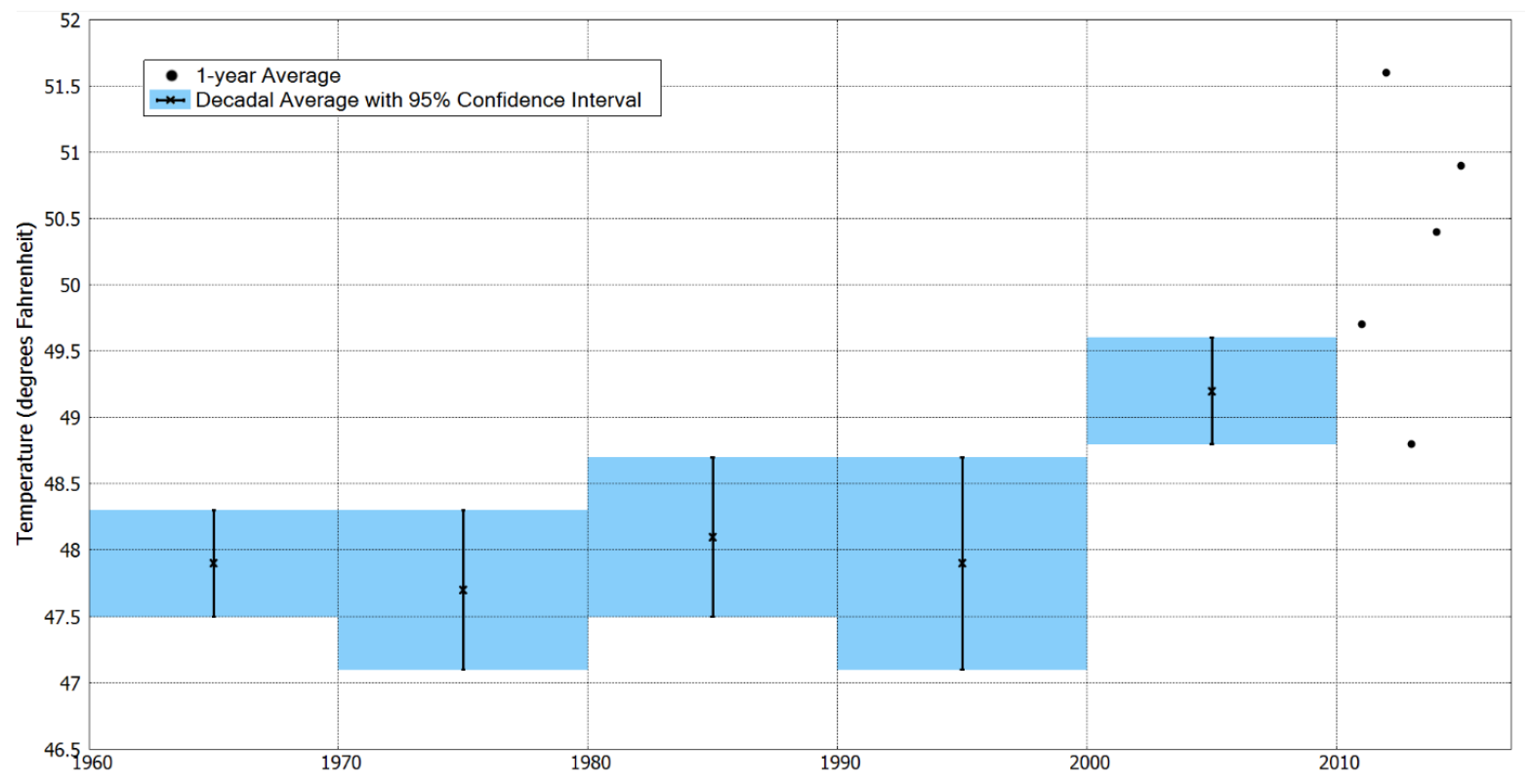

Figure 10-2: Decadal average temperatures and two times the standard error for Los Alamos (1960-2015). 
When the seasonal impacts on the trend in annual temperatures are reviewed, no trends are indicated using a Mann-Kendall test in wintertime (December-February) maximum and minimum temperatures. Summertime (June-August) maximum, minimum, and average temperatures since 1990 demonstrate a positive trend (Figure 10-3). Fall and spring temperatures also demonstrate a positive trend, but not as strong as summer temperatures.

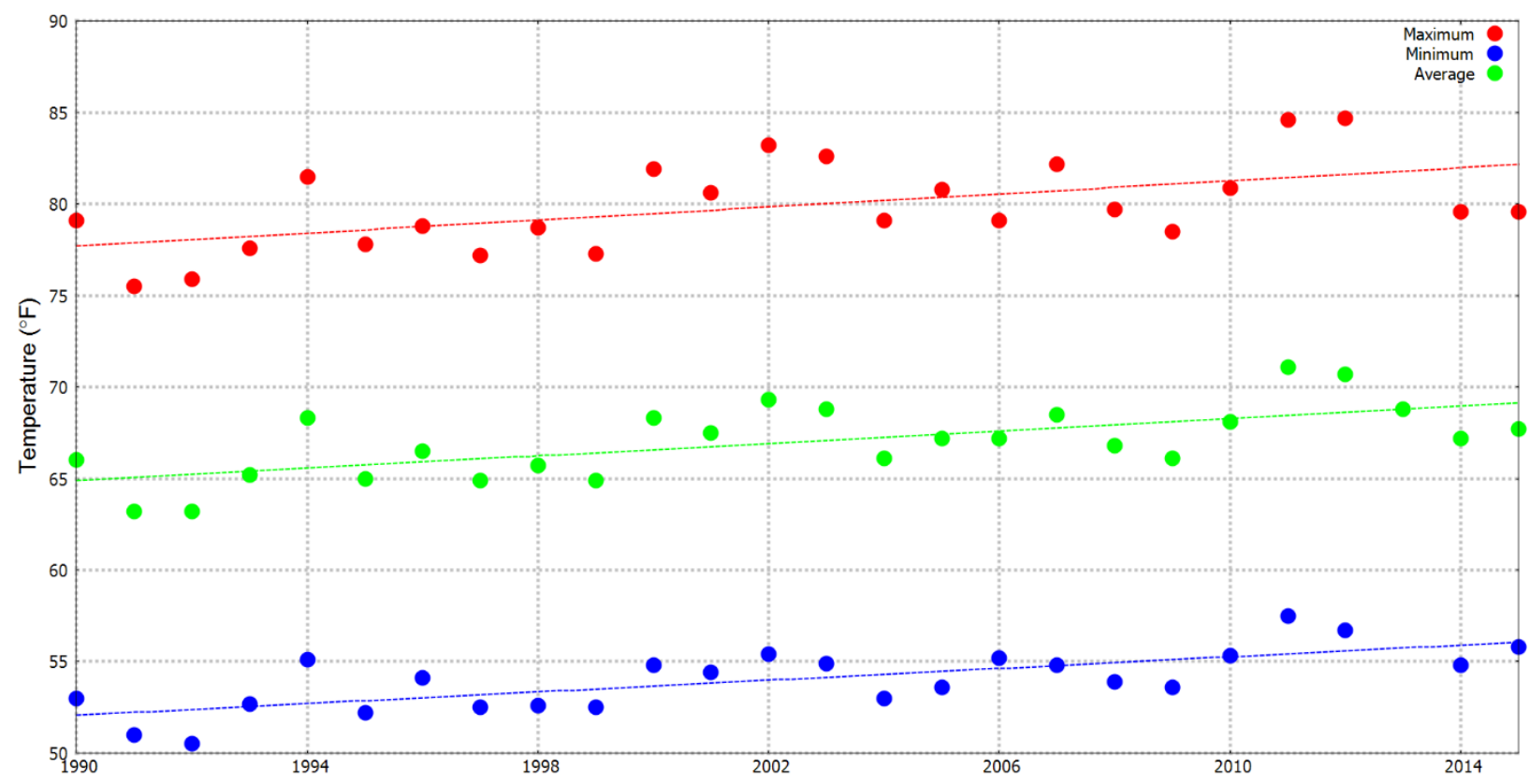

Figure 10-3: Annual average summertime temperatures for Los Alamos (1990-2015).

Five of the hottest summers on record have occurred since 2002. The highest summertime average temperature on record was $71.1^{\circ} \mathrm{F}$, recorded during 2011. There is a positive trend (using a MannKendall trend test) in the number of days with a maximum temperature greater than $90^{\circ} \mathrm{F}$ (Figure 10-4) and a negative trend in the number of days with a minimum temperature less than $0^{\circ} \mathrm{F}$ (Figure 10-5). 


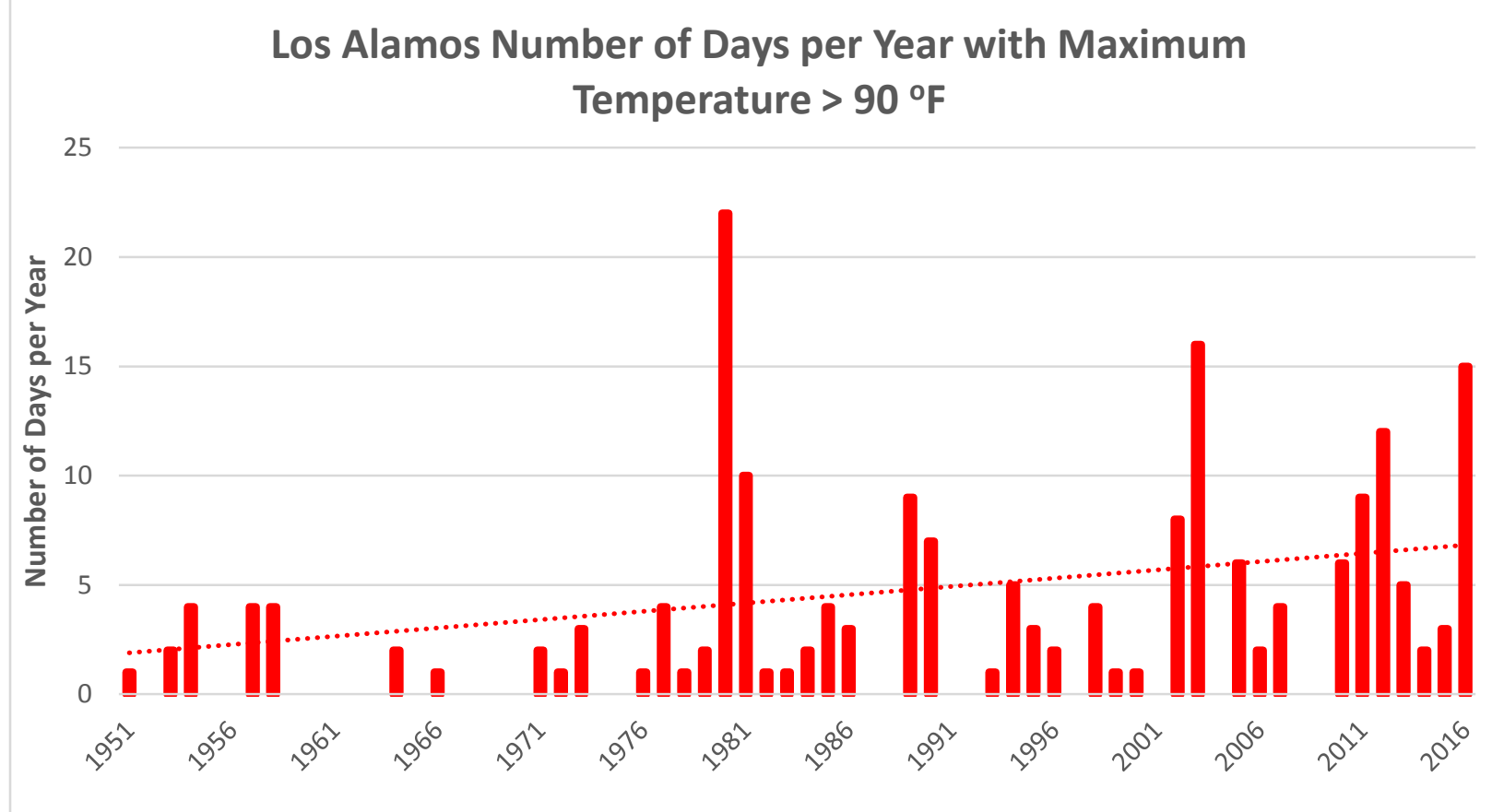

Figure 10-4: Number of days per year with maximum temperature above $90^{\circ} \mathrm{F}$ for Los Alamos.

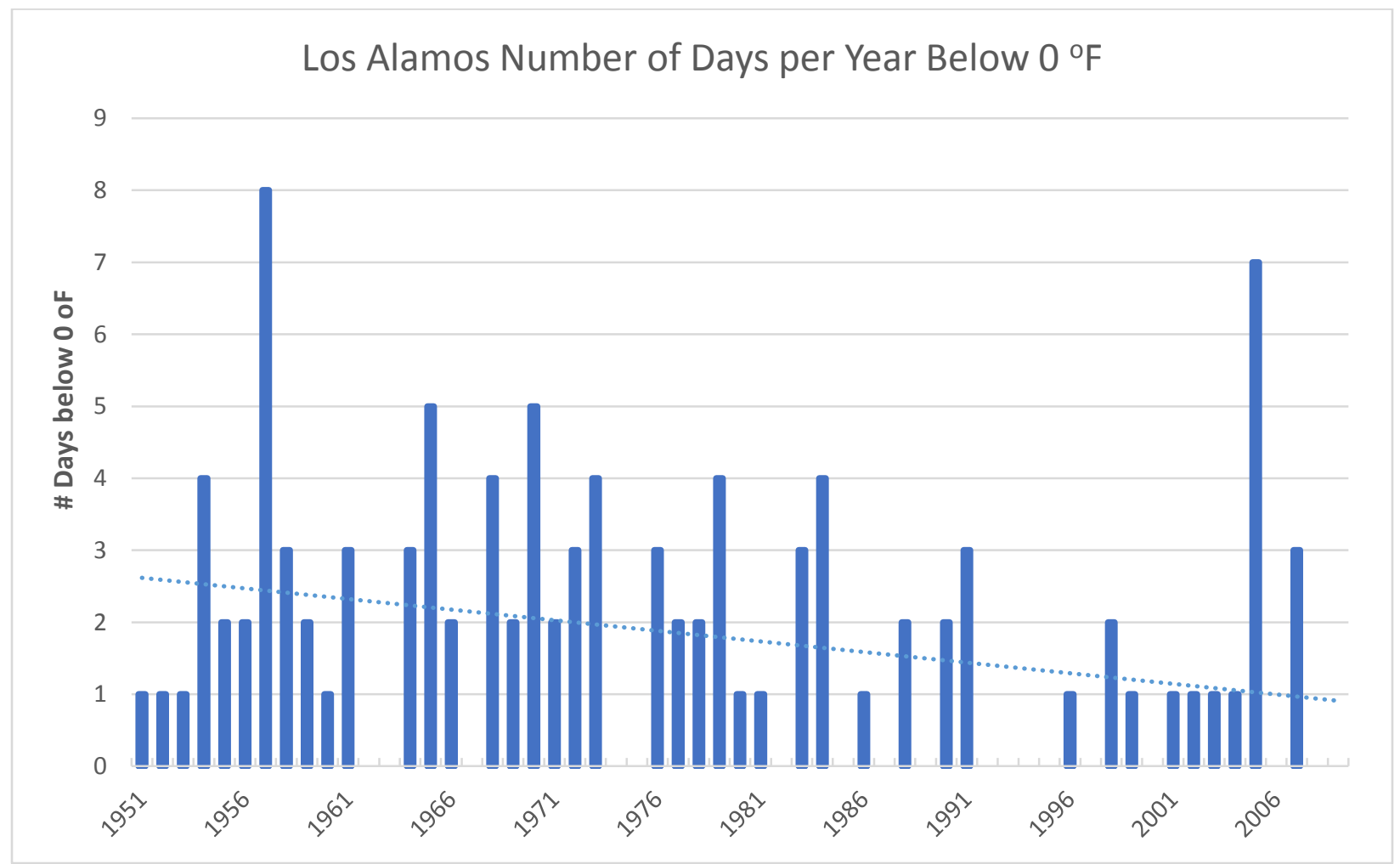

Figure 10-5: Number of days per year with minimum temperature less than $0^{\circ} \mathrm{F}$ for Los Alamos. 


\subsection{Precipitation}

Figure 10-6 presents the historical record of the annual precipitation at Los Alamos. As with the historical temperature profile, the 5-year running mean and the 30 -year normal values are also shown. There is a slight positive trend through the twentieth century followed by drought. The most recent drought spanned the years 1998 through 2014, although near-average precipitation years occurred from 2004-2010.

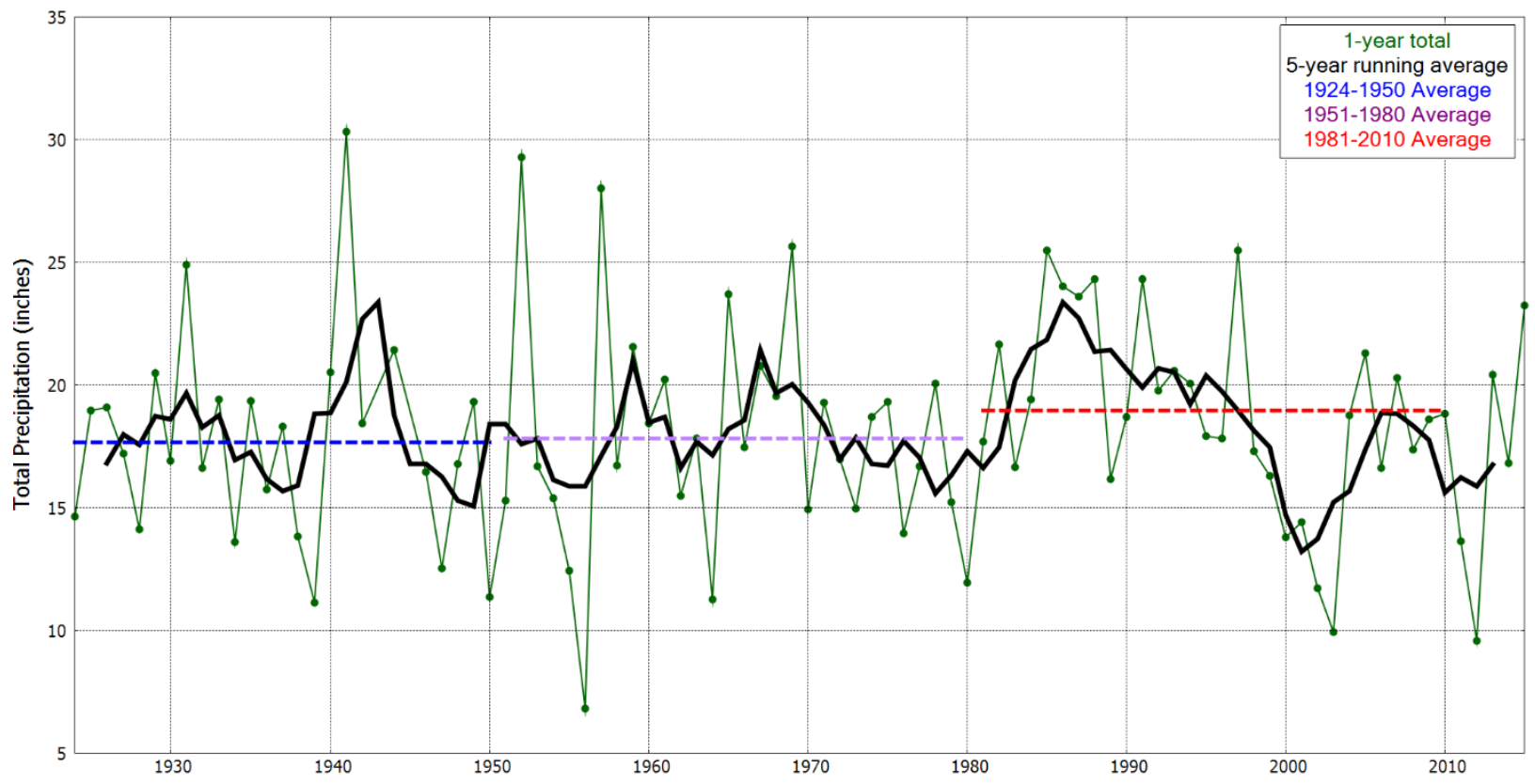

Figure 10-6: Precipitation history for Los Alamos (1924-2015).

Although the 30-year climatological average annual precipitation values have increased over the last century, this is in large part due to the very wet period of 1982 through 1997. Average annual precipitation exhibits a downward trend for 1981 to the present and snowfall (Figure 10-7) exhibits a downward trend for 1951 to the present. This is consistent with the impact of the most recent drought years.

In addition to the total amount of snowfall decreasing over the past 70 years, there is a decrease in the length of the snow season, the number of days between the average first measureable snowfall in the fall and the last measureable snowfall in the spring. Figure 10-8 presents the Julian date of the first and last snowfall of the year. In the early 1980s the first day of snow for the year was about November 4 and the final snowfall of the year was about April 18. Most recently, the first snowfall of the year occurs in late November and the final snowfall of the year occurs at the end of March. The snow season has decreased by about 6 weeks over the past 46 years. 


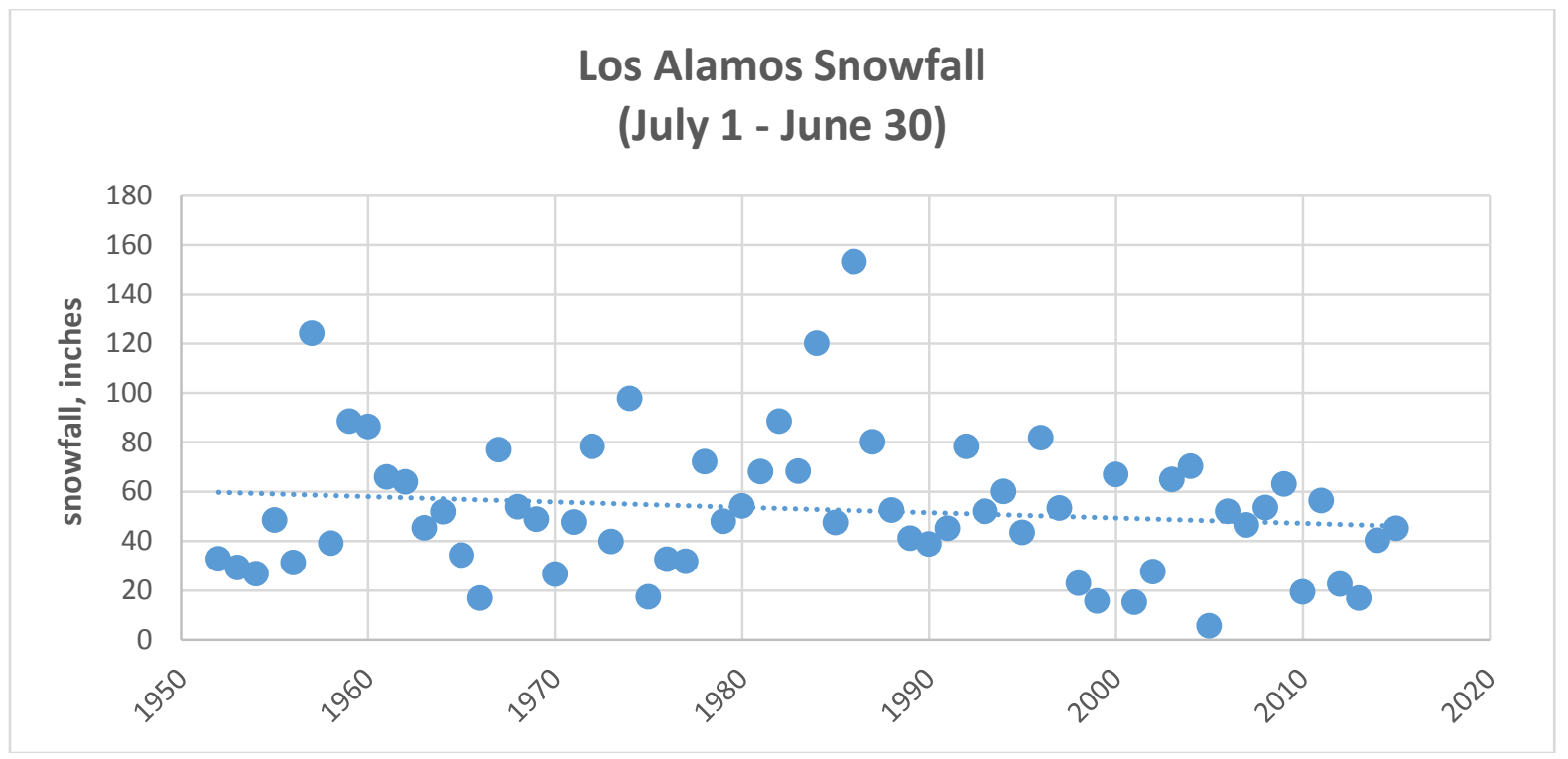

Figure 10-7: Annual snowfall (July 1-June 1) for Los Alamos (1951-2015).

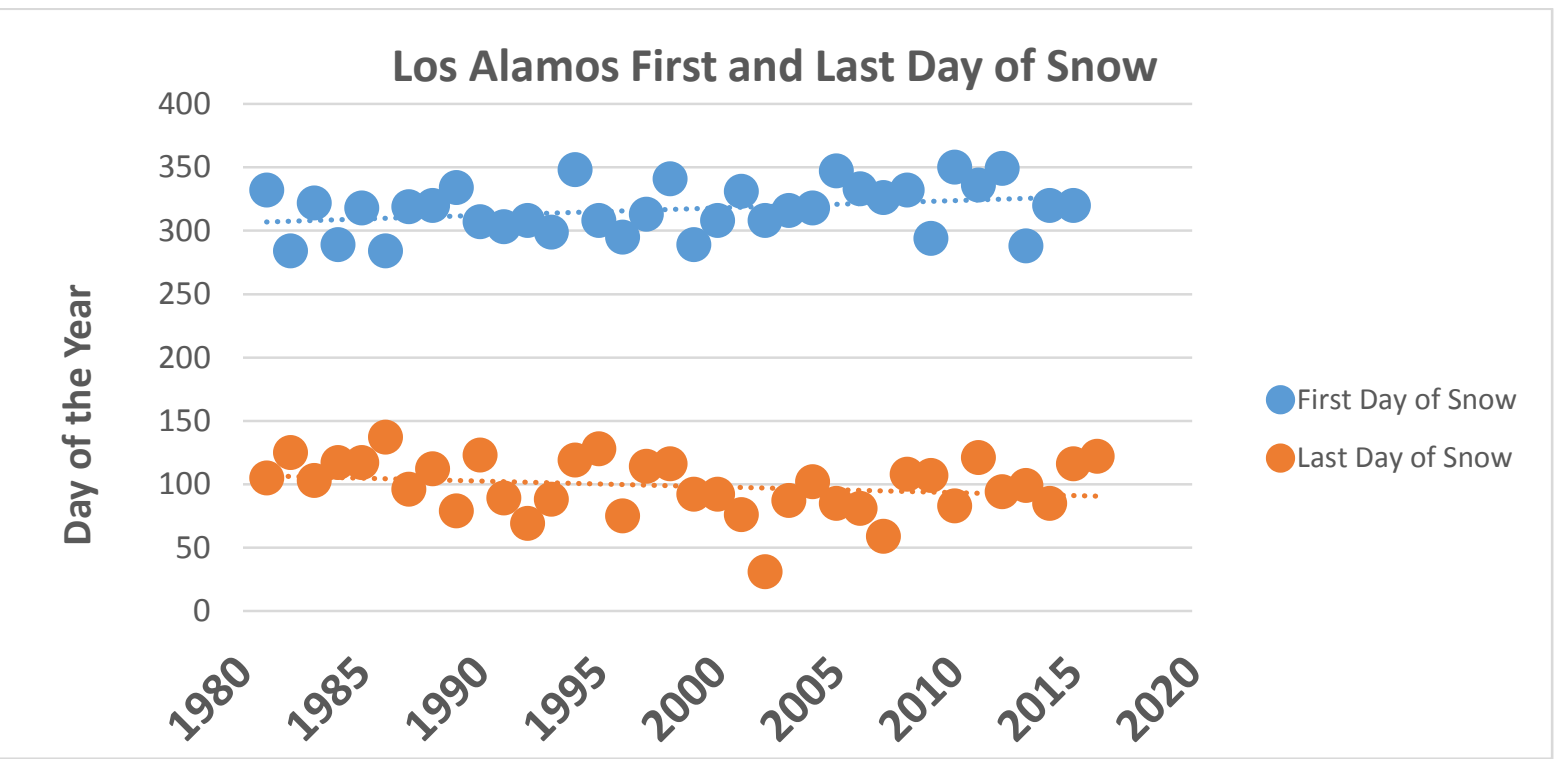

Figure 10-8: First and last day of snow for Los Alamos (1981-2016).

Los Alamos monsoon precipitation (June 15-September 30) does not demonstrate a significant trend from 1951 to the present, as seen in Figure 10-9. White Rock monsoon precipitation also does not demonstrate a significant trend from 1965 to the present. 


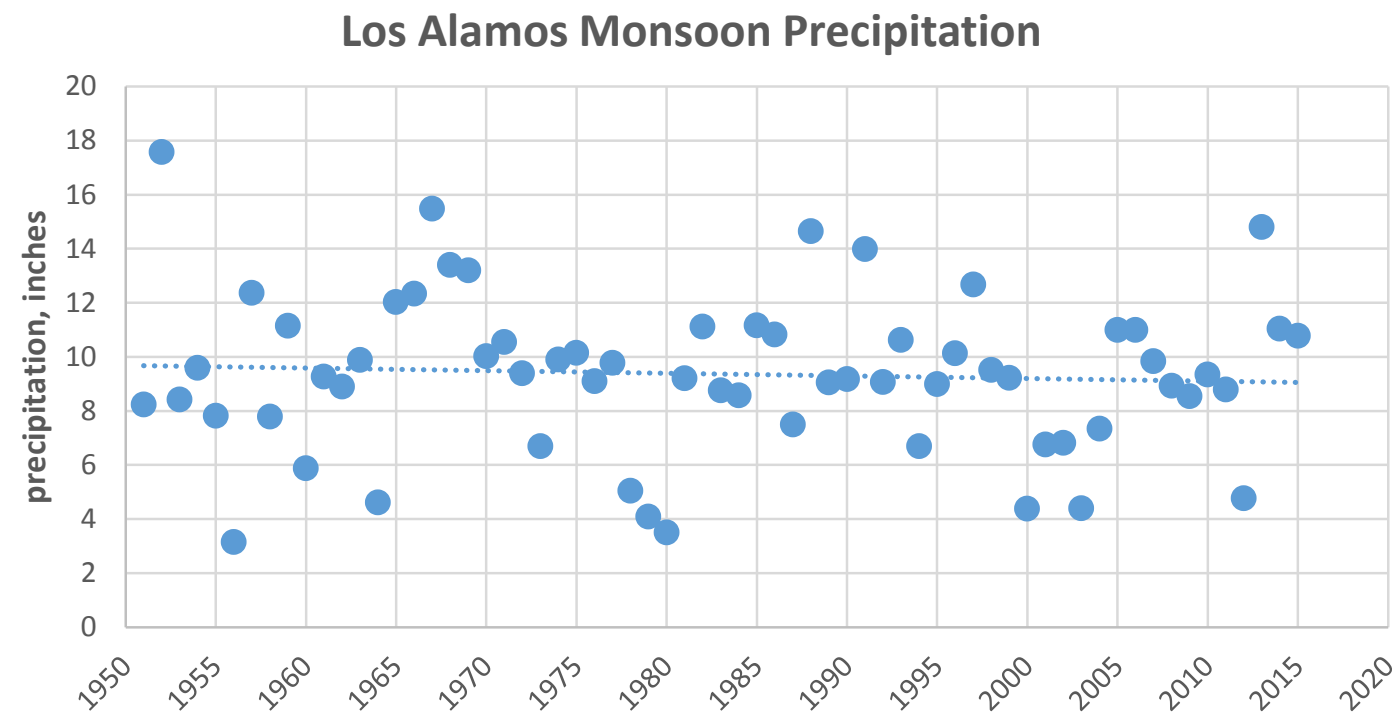

Figure 10-9: Annual monsoon precipitation for Los Alamos (1951-2015).

Heavy precipitation events demonstrate a very slight downward trend for the years 1951-present (Figure 10-10); however, the majority of the trend occurs during the 1981-present time period, reflecting the very wet years of the 1980s and the early 1990s followed by the drought from the late 1990 s to 2014. The number of days per year with precipitation greater than 0.75 inches also demonstrates a downward trend. For the years 1951-2010, the number of days with precipitation $>1.0$ inches has stayed very steady, at about two days per year.

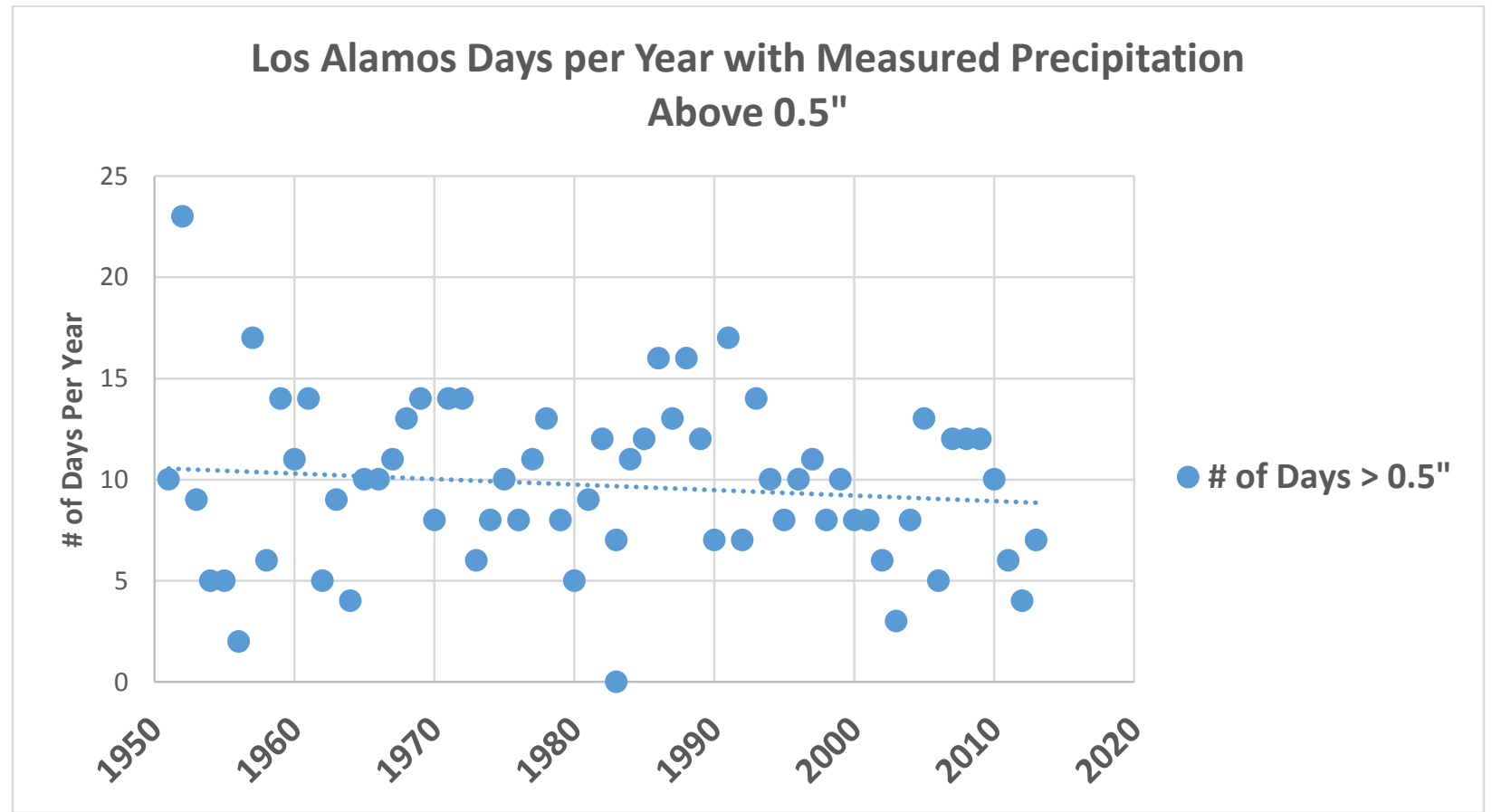

Figure 10-10: Number of days per year with measured rainfall ( $>0.5$ inches) for Los Alamos (1951-2015). 


\subsection{Wind Speed}

Wind speeds are fundamentally driven by temperature differences. The temperatures at the Earth's poles are increasing faster than at the equator, due to the impact of decreasing surface area of ice. This produces a decreased equator to pole temperature difference and this should produce a decrease in average wind speeds (Barton 2014). However, there are other forces that impact wind speed at the surface; primarily surface vegetation coverage. The impact of vegetation can be to slow down or speed up wind speeds due to frictional drag (Wever 2012). When there is more vegetation, wind speeds can be slowed; when there is less vegetation, winds can speed up.

The Laboratory has measured wind speed at the TA-6 tower location since 1992 . TA-6 is approximately 7400 feet in elevation; at this altitude, in 1992, the vegetation consisted of ponderosa pine and mixed conifer forests. In the past 23 years, the landscape at the Laboratory at this altitude has changed dramatically. The impact of forest fires in 2000 and 2011, the drought and bark beetle infestations in the early 2000s, and the ongoing LANL forest thinning projects (to reduce wildland fire danger) have reduced the amount of ponderosa pine and mixed conifer forest coverage since 1992 (McKown et al. 2003).

Figure 10-11 presents the annual average 12-meter-height wind speed at TA-6 from 1994 through 2015. Essentially no change in wind speed was measured between 1994 and 2001. The annual average wind speed increased by approximately $20 \%$ between 2001 and 2014 . The annual average wind speed decreased in 2015 by about $10 \%$. The increase in wind speed between 2001 and 2014 is consistent with a reduction in frictional drag due to the reduction of ponderosa pine and mixed conifer forests at LANL.

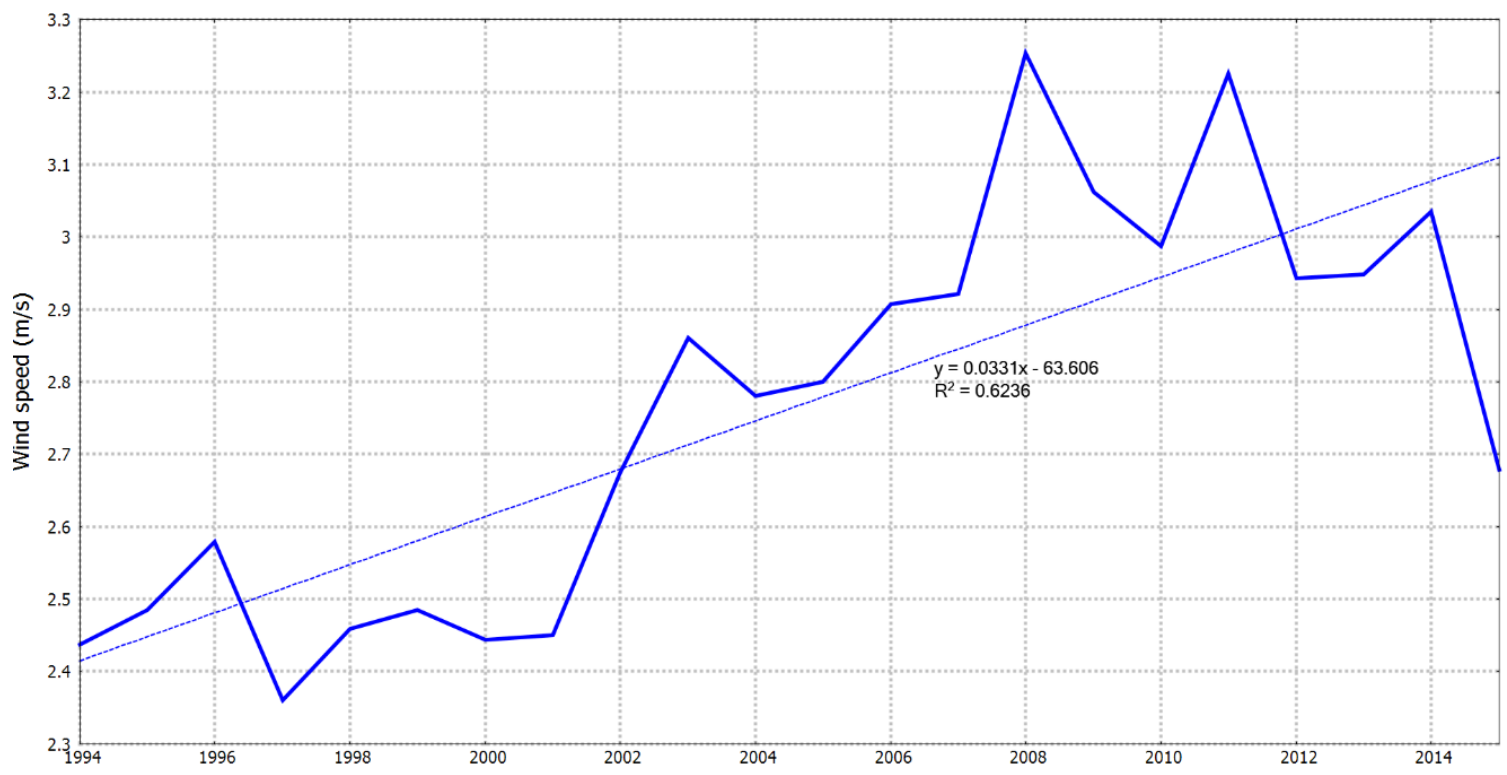

Figure 10-11: Annual average wind speed at 12 meters AGL at TA-6 (1994-2015).

Other factors may be influencing the change in average wind speed, however. The measured increase in surface temperatures should also lead to an increase in the vertical mixing of the atmosphere. Increased mixing of the atmosphere should produce higher surface wind speeds as higher wind speeds aloft are mixed to the surface. Further analysis of wind speed data is needed to determine the driving mechanisms for these observations. 


\subsection{REFERENCES}

Adams, D. K. and A. C. Comrie 1997: The North American Monsoon. Bull. Amer. Meteor. Soc., 78, 2197-2213.

ANSI 2010: ANSI/ANS-3.11-2015: Determining Meteorological Information at Nuclear Facilities. American National Standards Institute, 56 pp.

Barton, B. T. 2014: Reduced wind strengths top-down control of an insect herbivore. Ecology, 95, 2375-2381, doi:10.1890/13-2171.1.

Bowen, B. M. 1990: Los Alamos Climatology. LA-11735-MS.

Bruggeman, D. A. 2016: Meteorology Assessment of Historic Rainfall for Los Alamos During September 2013. LA-UR-16-20869.

Crimmins, M. A. 2006: Arizona and the North American Monsoon System. University of Arizona Cooperative Extension, 8 pp. [Available online at http://cals.arizona.edu/pubs/natresources/az1417.pdf.]

Dewart, J. and M. Boggs 2014: Meteorological Monitoring at Los Alamos. LA-UR-14-23378.

DOE 2015: Environmental Radiological Effluent Monitoring and Environmental Surveillance. DOE-HDBK-1216-2015.

EPA 2000: US Environmental Protection Agency, Meteorological Monitoring Guidance for Regulatory Modeling Applications, EPA-454/4-99-005.

Garfin, G., A. Jardine, R. Merideth, M. Black, and S. LeRoy 2013: Assessment of Climate Change in the Southwest United States. 506 pp, doi:10.5822/978-1-61091-484-0.

Gutzler, D. S. 2000: Covariability of Spring Snowpack and Summer Rainfall across the Southwest United States. J. Climate., 13, 4018-4027.

Gutzler, D., S. Sullivan, and D. Kann 2016: An Extreme Annual Precipitation Anomaly in the Preradiosonde Era. Bull. Amer. Meteor. Soc., 97, 989-1001, doi:10.1175/BAMS-D-1400142.1.

IPCC 2013: Climate Change 2013: The Physical Science Basis. Contribution of Working Group 1 to the Fifth Assessment Report of the Intergovernmental Panel on Climate Change. 1535 pp, doi:10.1017/CBO9781107415324.

Kelly, E., J. Dewart, and R. Deola 2015: Analysis of Precipitation (Rain and Snow) Levels and Straight-line Wind Speeds in Support of the 10-year Natural Phenomena Hazards Review for Los Alamos National Laboratory. LA-UR-15-29420.

Machen, J., E. D. McGehee, and D. Hoard 2014: Homesteading on the Pajarito Plateau, 1887-1942. LA-UR-12-24602.

McKown, B., S. W. Koch, R. G. Balice, and P. Neville 2003: Land Cover Map for the Eastern Jemez Region. LA-14029. 
Melillo, J. M., T. C. Richmond, and G. W. Yohe 2014: Climate Change Impacts in the United States: The Third National Climate Assessment. U.S. Global Change Research Program, 841 pp. doi:10.7930/J0Z31WJ2.

NEO 2016: What in the World is a Degree Day? Nebraska Department of Energy. Accessed May 2016. [Available online at http://www.neo.ne.gov/neq_online/july2005/july2005.07.htm.]

NOAA 2016a: What is El Niño-Southern Oscillation (ENSO)? Accessed 9 September 2016. [Available online at http://www.weather.gov/ict/enso.]

NOAA 2016b: Climate Data Online Search. National Centers for Environmental Information. Accessed February 2016. [Available online at https://www.ncdc.noaa.gov/cdo-web/search.]

Peel, M. C., B. L. Finlayson, and T. A. McMahon 2007: Updated world map of the Köppen-Geiger climate classification. Hydrol. Earth Syst. Sci., 11, 1633-1644.

Sampson G. and E. Pytlak 2008: Educating the Public on the North American Monsoon System. National Weather Service, Tucson, Arizona.

Wever, N. 2012: Quantifying trends in surface roughness and the effect on surface wind speed observations. J. Geophys. Res., 117, D11104, doi:10.1029/2011JD017118.

WMO 1989: Calculation of Monthly and Annual 30-Year Standard Normals. WCDP-No. 10, WMOTD/No. 341, World Meteorological Organization.

Youngman, B. 2016: Climate and Earth's Energy Balance. EarthLabs. Accessed September 2016. [Available online at http://serc.carleton.edu/eslabs/weather/2.html.] 


\section{APPENDIX \\ Monthly Average Temperatures and Precipitation for Los Alamos and White Rock}





\section{Los Alamos Temperatures}

Data is for tower laarc. This file was obtained from the LANL Weather Machine http://weather.lanl.gov. Request made on Thursday, July 14 09:15:33 2016 MST.

\begin{tabular}{|l|c|r|r|}
\hline \multicolumn{1}{|c|}{ Month } & Year & $\begin{array}{c}\text { Average Max } \\
\left.\text { Temp ( }{ }^{\circ} \text { F }\right)\end{array}$ & $\begin{array}{c}\text { Average Min } \\
\left.\text { Temp ( }{ }^{\circ} \mathbf{F}\right)\end{array}$ \\
\hline January & 1951 & 40.3 & 22.4 \\
\hline February & 1951 & 41.3 & 24.2 \\
\hline March & 1951 & 46.9 & 27.2 \\
\hline April & 1951 & 56.0 & 34.7 \\
\hline May & 1951 & 65.8 & 45.0 \\
\hline June & 1951 & 75.7 & 53.9 \\
\hline July & 1951 & 82.4 & 60.7 \\
\hline August & 1951 & 76.3 & 56.4 \\
\hline September & 1951 & 73.9 & 51.9 \\
\hline October & 1951 & 61.4 & 43.0 \\
\hline November & 1951 & 47.4 & 28.0 \\
\hline December & 1951 & 38.2 & 23.8 \\
\hline January & 1952 & 40.0 & 23.3 \\
\hline February & 1952 & 41.8 & 21.4 \\
\hline March & 1952 & 42.0 & 23.4 \\
\hline April & 1952 & 56.6 & 35.6 \\
\hline May & 1952 & 65.4 & 45.4 \\
\hline June & 1952 & 79.2 & 57.7 \\
\hline July & 1952 & 79.5 & 56.3 \\
\hline August & 1952 & 78.2 & 57.0 \\
\hline September & 1952 & 73.4 & 50.4 \\
\hline October & 1952 & 67.0 & 42.1 \\
\hline November & 1952 & 42.6 & 24.8 \\
\hline December & 1952 & 36.1 & 19.5 \\
\hline January & 1953 & 49.1 & 26.0 \\
\hline February & 1953 & 43.6 & 21.7 \\
\hline March & 1953 & 53.3 & 31.1 \\
\hline April & 1953 & 58.8 & 35.7 \\
\hline May & 1953 & 63.0 & 41.3 \\
\hline June & 1953 & 81.3 & 57.0 \\
\hline July & 1953 & 82.1 & 58.9 \\
\hline August & 1953 & 78.7 & 55.6 \\
\hline September & 1953 & 78.0 & 52.4 \\
\hline October & 1953 & 63.5 & 41.1 \\
\hline November & 1953 & 51.8 & 31.2 \\
\hline December & 1953 & 38.2 & 20.0 \\
\hline January & 1954 & 42.9 & 24.3 \\
\hline
\end{tabular}

\begin{tabular}{|l|c|r|r|}
\hline \multicolumn{1}{|c|}{ Month } & Year & $\begin{array}{c}\text { Average Max } \\
\text { Temp }\left({ }^{\circ} \mathbf{F}\right)\end{array}$ & $\begin{array}{c}\text { Average Min } \\
\text { Temp }\left({ }^{\circ} \mathbf{F}\right)\end{array}$ \\
\hline February & 1954 & 53.2 & 29.8 \\
\hline March & 1954 & 47.8 & 27.9 \\
\hline April & 1954 & 65.6 & 42.9 \\
\hline May & 1954 & 67.9 & 46.0 \\
\hline June & 1954 & 79.6 & 55.0 \\
\hline July & 1954 & 81.3 & 58.1 \\
\hline August & 1954 & 78.4 & 55.5 \\
\hline September & 1954 & 74.8 & 52.6 \\
\hline October & 1954 & 65.7 & 43.4 \\
\hline November & 1954 & 55.1 & 32.1 \\
\hline December & 1954 & 43.2 & 23.3 \\
\hline January & 1955 & 36.8 & 19.4 \\
\hline February & 1955 & 37.1 & 17.9 \\
\hline March & 1955 & 49.3 & 28.8 \\
\hline April & 1955 & 55.7 & 35.3 \\
\hline May & 1955 & 64.0 & 43.4 \\
\hline June & 1955 & 76.4 & 52.2 \\
\hline July & 1955 & 79.1 & 56.3 \\
\hline August & 1955 & 77.7 & 56.4 \\
\hline September & 1955 & 76.0 & 52.2 \\
\hline October & 1955 & 66.9 & 42.4 \\
\hline November & 1955 & 50.9 & 28.7 \\
\hline December & 1955 & 44.4 & 25.1 \\
\hline January & 1956 & 44.9 & 27.0 \\
\hline February & 1956 & 38.6 & 19.5 \\
\hline March & 1956 & 52.7 & 30.0 \\
\hline April & 1956 & 56.5 & 36.1 \\
\hline May & 1956 & 70.8 & 50.2 \\
\hline June & 1956 & 80.2 & 58.3 \\
\hline July & 1956 & 79.3 & 58.5 \\
\hline August & 1956 & 76.8 & 56.5 \\
\hline September & 1956 & 80.0 & 51.5 \\
\hline October & 1956 & 64.9 & 39.8 \\
\hline November & 1956 & 47.8 & 22.5 \\
\hline December & 1956 & 43.4 & 20.8 \\
\hline January & 1957 & 40.1 & 22.4 \\
\hline February & 1957 & 49.5 & 29.3 \\
\hline
\end{tabular}




\begin{tabular}{|l|c|r|r|}
\hline \multicolumn{1}{|c|}{ Month } & Year & $\begin{array}{c}\text { Average Max } \\
\left.\text { Temp ( }{ }^{\circ} \mathbf{F}\right)\end{array}$ & $\begin{array}{c}\text { Average Min } \\
\left.\text { Temp ( }{ }^{\circ} \mathbf{F}\right)\end{array}$ \\
\hline March & 1957 & 48.6 & 28.4 \\
\hline April & 1957 & 55.6 & 31.4 \\
\hline May & 1957 & 61.1 & 39.0 \\
\hline June & 1957 & 77.4 & 51.1 \\
\hline July & 1957 & 79.8 & 55.7 \\
\hline August & 1957 & 75.4 & 52.6 \\
\hline September & 1957 & 73.0 & 46.7 \\
\hline October & 1957 & 56.3 & 36.6 \\
\hline November & 1957 & 41.2 & 20.7 \\
\hline December & 1957 & 42.9 & 21.1 \\
\hline January & 1958 & 38.9 & 16.9 \\
\hline February & 1958 & 45.4 & 23.6 \\
\hline March & 1958 & 40.8 & 22.2 \\
\hline April & 1958 & 52.6 & 30.5 \\
\hline May & 1958 & 69.5 & 43.8 \\
\hline June & 1958 & 79.5 & 53.2 \\
\hline July & 1958 & 81.9 & 54.9 \\
\hline August & 1958 & 78.6 & 54.2 \\
\hline September & 1958 & 70.9 & 49.4 \\
\hline October & 1958 & 60.4 & 39.1 \\
\hline November & 1958 & 51.0 & 28.5 \\
\hline December & 1958 & 48.5 & 24.6 \\
\hline January & 1959 & 41.3 & 19.9 \\
\hline February & 1959 & 41.2 & 21.0 \\
\hline March & 1959 & 49.2 & 24.5 \\
\hline April & 1959 & 57.8 & 33.7 \\
\hline May & 1959 & 66.5 & 43.3 \\
\hline June & 1959 & 78.3 & 54.0 \\
\hline July & 1959 & 79.3 & 55.9 \\
\hline August & 1959 & 76.2 & 55.5 \\
\hline September & 1959 & 74.0 & 49.1 \\
\hline October & 1959 & 59.7 & 37.4 \\
\hline November & 1959 & 49.2 & 25.2 \\
\hline December & 1959 & 43.8 & 23.2 \\
\hline January & 1960 & 35.1 & 14.3 \\
\hline February & 1960 & 35.9 & 16.5 \\
\hline March & 1960 & 51.3 & 28.2 \\
\hline April & 1960 & 61.0 & 35.5 \\
\hline June & 196.5 & 78.8 & 54.6 \\
\hline
\end{tabular}

\begin{tabular}{|l|c|r|r|}
\hline \multicolumn{1}{|c|}{ Month } & Year & $\begin{array}{c}\text { Average Max } \\
\text { Temp ( }{ }^{\circ} \text { F }\end{array}$ & $\begin{array}{c}\text { Average Min } \\
\text { Temp ( }{ }^{\circ} \text { F }\end{array}$ \\
\hline August & 1960 & 80.1 & 54.6 \\
\hline September & 1960 & 73.9 & 48.7 \\
\hline October & 1960 & 59.9 & 37.2 \\
\hline November & 1960 & 51.2 & 28.1 \\
\hline December & 1960 & 38.4 & 17.8 \\
\hline January & 1961 & 40.6 & 16.8 \\
\hline February & 1961 & 44.7 & 22.0 \\
\hline March & 1961 & 48.0 & 27.4 \\
\hline April & 1961 & 56.2 & 32.2 \\
\hline May & 1961 & 68.6 & 43.2 \\
\hline June & 1961 & 78.5 & 51.7 \\
\hline July & 1961 & 81.4 & 54.5 \\
\hline August & 1961 & 76.4 & 53.7 \\
\hline September & 1961 & 69.6 & 45.1 \\
\hline October & 1961 & 63.0 & 38.2 \\
\hline November & 1961 & 44.6 & 26.0 \\
\hline December & 1961 & 38.2 & 16.6 \\
\hline January & 1962 & 37.8 & 16.0 \\
\hline February & 1962 & 45.9 & 26.1 \\
\hline March & 1962 & 45.1 & 23.0 \\
\hline April & 1962 & 63.1 & 36.8 \\
\hline May & 1962 & 69.1 & 44.1 \\
\hline June & 1962 & 77.2 & 50.7 \\
\hline July & 1962 & 78.1 & 53.9 \\
\hline August & 1962 & 81.7 & 55.9 \\
\hline September & 1962 & 71.1 & 49.2 \\
\hline October & 1962 & 63.7 & 40.0 \\
\hline November & 1962 & 52.0 & 29.9 \\
\hline December & 1962 & 43.9 & 21.7 \\
\hline January & 1963 & 36.6 & 12.9 \\
\hline February & 1963 & 44.0 & 21.2 \\
\hline March & 1963 & 48.9 & 25.5 \\
\hline April & 1963 & 59.7 & 34.3 \\
\hline May & 1963 & 72.3 & 47.0 \\
\hline June & 1963 & 76.7 & 50.2 \\
\hline July & 1963 & 82.9 & 58.2 \\
\hline August & 1963 & 76.4 & 54.2 \\
\hline September & 1963 & 74.1 & 50.1 \\
\hline October & 1963 & 66.2 & 43.1 \\
\hline November & 1963 & 51.9 & 29.6 \\
\hline December & 1963 & 42.6 & 19.2 \\
\hline
\end{tabular}




\begin{tabular}{|l|c|r|r|}
\hline \multicolumn{1}{|c|}{ Month } & Year & $\begin{array}{c}\text { Average Max } \\
\left.\text { Temp ( }{ }^{\circ} \mathbf{F}\right)\end{array}$ & $\begin{array}{c}\text { Average Min } \\
\left.\text { Temp ( }{ }^{\circ} \mathbf{F}\right)\end{array}$ \\
\hline January & 1964 & 37.7 & 13.9 \\
\hline February & 1964 & 34.6 & 13.0 \\
\hline March & 1964 & 45.4 & 23.2 \\
\hline April & 1964 & 54.3 & 30.9 \\
\hline May & 1964 & 68.2 & 41.9 \\
\hline June & 1964 & 76.7 & 50.6 \\
\hline July & 1964 & 81.1 & 57.0 \\
\hline August & 1964 & 78.1 & 54.9 \\
\hline September & 1964 & 70.4 & 48.2 \\
\hline October & 1964 & 64.8 & 39.2 \\
\hline November & 1964 & 48.4 & 25.8 \\
\hline December & 1964 & 39.2 & 18.8 \\
\hline January & 1965 & 41.2 & 20.1 \\
\hline February & 1965 & 41.4 & 17.6 \\
\hline March & 1965 & 44.4 & 23.0 \\
\hline April & 1965 & 57.4 & 34.1 \\
\hline May & 1965 & 64.7 & 39.7 \\
\hline June & 1965 & 73.3 & 47.5 \\
\hline July & 1965 & 79.4 & 55.8 \\
\hline August & 1965 & 76.3 & 52.9 \\
\hline September & 1965 & 67.3 & 45.2 \\
\hline October & 1965 & 64.6 & 39.0 \\
\hline November & 1965 & 52.6 & 30.8 \\
\hline December & 1965 & 42.3 & 21.4 \\
\hline January & 1966 & 35.3 & 14.3 \\
\hline February & 1966 & 36.5 & 15.1 \\
\hline March & 1966 & 52.4 & 28.1 \\
\hline April & 1966 & 59.8 & 34.2 \\
\hline May & 1966 & 71.2 & 44.3 \\
\hline June & 1966 & 75.9 & 51.2 \\
\hline July & 1966 & 82.1 & 59.3 \\
\hline August & 1966 & 76.0 & 53.8 \\
\hline September & 1966 & 71.7 & 48.9 \\
\hline October & 1966 & 62.3 & 37.9 \\
\hline November & 1966 & 52.3 & 31.4 \\
\hline December & 1966 & 40.5 & 21.2 \\
\hline January & 1967 & 41.7 & 18.1 \\
\hline February & 1967 & 45.3 & 23.1 \\
\hline March & 1967 & 56.1 & 32.3 \\
\hline May & 1967 & 59.3 & 34.9 \\
\hline
\end{tabular}

\begin{tabular}{|l|c|r|r|}
\hline \multicolumn{1}{|c|}{ Month } & Year & $\begin{array}{c}\text { Average Max } \\
\left.\text { Temp ( }{ }^{\circ} \mathbf{F}\right)\end{array}$ & $\begin{array}{c}\text { Average Min } \\
\left.\text { Temp ( }{ }^{\circ} \mathbf{F}\right)\end{array}$ \\
\hline June & 1967 & 73.6 & 50.5 \\
\hline July & 1967 & 79.4 & 56.7 \\
\hline August & 1967 & 74.2 & 52.9 \\
\hline September & 1967 & 68.8 & 47.8 \\
\hline October & 1967 & 63.7 & 39.4 \\
\hline November & 1967 & 51.4 & 30.4 \\
\hline December & 1967 & 34.7 & 15.1 \\
\hline January & 1968 & 40.4 & 19.4 \\
\hline February & 1968 & 44.6 & 25.4 \\
\hline March & 1968 & 48.4 & 28.6 \\
\hline April & 1968 & 53.3 & 30.5 \\
\hline May & 1968 & 65.0 & 41.9 \\
\hline June & 1968 & 79.0 & 52.8 \\
\hline July & 1968 & 77.1 & 55.3 \\
\hline August & 1968 & 71.9 & 52.3 \\
\hline September & 1968 & 71.3 & 46.6 \\
\hline October & 1968 & 63.7 & 39.2 \\
\hline November & 1968 & 46.1 & 26.6 \\
\hline December & 1968 & 38.8 & 16.7 \\
\hline January & 1969 & 43.1 & 24.7 \\
\hline February & 1969 & 42.1 & 22.2 \\
\hline March & 1969 & 43.7 & 21.2 \\
\hline April & 1969 & 59.1 & 35.6 \\
\hline May & 1969 & 68.7 & 44.4 \\
\hline June & 1969 & 74.1 & 49.2 \\
\hline July & 1969 & 80.5 & 58.1 \\
\hline August & 1969 & 79.7 & 57.3 \\
\hline September & 1969 & 70.4 & 49.0 \\
\hline October & 1969 & 55.3 & 35.4 \\
\hline November & 1969 & 47.5 & 26.4 \\
\hline December & 1969 & 42.2 & 24.6 \\
\hline January & 1970 & 39.4 & 17.7 \\
\hline February & 1970 & 46.4 & 26.1 \\
\hline March & 1970 & 44.3 & 24.1 \\
\hline April & 1970 & 54.6 & 31.2 \\
\hline May & 1970 & 69.0 & 44.7 \\
\hline June & 1970 & 74.1 & 50.0 \\
\hline July & 1970 & 79.8 & 55.9 \\
\hline Sugust & 1970 & 78.8 & 56.4 \\
\hline October & 1970 & 69.4 & 46.8 \\
\hline
\end{tabular}




\begin{tabular}{|l|c|c|c|}
\hline \multicolumn{1}{|c|}{ Month } & Year & $\begin{array}{c}\text { Average Max } \\
\left.\text { Temp ( }{ }^{\circ} \mathrm{F}\right)\end{array}$ & $\begin{array}{c}\text { Average Min } \\
\left.\text { Temp ( }{ }^{\circ} \mathbf{F}\right)\end{array}$ \\
\hline November & 1970 & 50.1 & 27.4 \\
\hline December & 1970 & 43.9 & 20.5 \\
\hline January & 1971 & 41.1 & 17.2 \\
\hline February & 1971 & 42.0 & 19.9 \\
\hline March & 1971 & 52.5 & 25.7 \\
\hline April & 1971 & 57.1 & 32.6 \\
\hline May & 1971 & 65.8 & 41.1 \\
\hline June & 1971 & 78.1 & 52.7 \\
\hline July & 1971 & 79.5 & 55.6 \\
\hline August & 1971 & 76.0 & 52.3 \\
\hline September & 1971 & 69.1 & 45.2 \\
\hline October & 1971 & 57.1 & 35.1 \\
\hline November & 1971 & 47.8 & 26.4 \\
\hline December & 1971 & 37.3 & 17.1 \\
\hline January & 1972 & 41.7 & 17.7 \\
\hline February & 1972 & 48.1 & 23.9 \\
\hline March & 1972 & 58.5 & 33.2 \\
\hline April & 1972 & 62.2 & 36.6 \\
\hline May & 1972 & 67.7 & 43.1 \\
\hline June & 1972 & 76.7 & 52.6 \\
\hline July & 1972 & 79.2 & 55.5 \\
\hline August & 1972 & 74.5 & 52.9 \\
\hline September & 1972 & 68.8 & 47.7 \\
\hline October & 1972 & 56.8 & 39.2 \\
\hline November & 1972 & 39.6 & 21.3 \\
\hline December & 1972 & 38.4 & 18.4 \\
\hline January & 1973 & 35.8 & 16.4 \\
\hline February & 1973 & 39.3 & 20.9 \\
\hline March & 1973 & 42.6 & 24.4 \\
\hline April & 1973 & 51.1 & 28.2 \\
\hline May & 1973 & 64.9 & 41.8 \\
\hline June & 1973 & 76.7 & 50.8 \\
\hline July & 1973 & 78.7 & 55.9 \\
\hline August & 1973 & 80.3 & 55.7 \\
\hline September & 1973 & 71.2 & 47.7 \\
\hline October & 1973 & 62.3 & 39.7 \\
\hline November & 1973 & 52.1 & 31.0 \\
\hline December & 1973 & 42.0 & 20.7 \\
\hline Manuary & 1974 & 36.4 & 16.2 \\
\hline
\end{tabular}

\begin{tabular}{|l|c|r|r|}
\hline \multicolumn{1}{|c|}{ Month } & Year & $\begin{array}{c}\text { Average Max } \\
\text { Temp ( }{ }^{\circ} \text { F) }\end{array}$ & $\begin{array}{c}\text { Average Min } \\
\text { Temp ( }{ }^{\circ} \text { F) }\end{array}$ \\
\hline April & 1974 & 58.8 & 33.1 \\
\hline May & 1974 & 72.7 & 46.2 \\
\hline June & 1974 & 80.6 & 54.0 \\
\hline July & 1974 & 78.9 & 55.2 \\
\hline August & 1974 & 74.7 & 52.1 \\
\hline September & 1974 & 68.4 & 45.5 \\
\hline October & 1974 & 56.8 & 39.2 \\
\hline November & 1974 & 47.7 & 26.6 \\
\hline December & 1974 & 37.2 & 16.4 \\
\hline January & 1975 & 38.7 & 14.9 \\
\hline February & 1975 & 39.7 & 18.5 \\
\hline March & 1975 & 47.2 & 27.2 \\
\hline April & 1975 & 53.2 & 30.0 \\
\hline May & 1975 & 65.7 & 39.7 \\
\hline June & 1975 & 77.2 & 49.6 \\
\hline July & 1975 & 78.1 & 53.7 \\
\hline August & 1975 & 79.0 & 54.0 \\
\hline September & 1975 & 67.9 & 46.0 \\
\hline October & 1975 & 62.2 & 36.2 \\
\hline November & 1975 & 48.4 & 25.1 \\
\hline December & 1975 & 41.8 & 20.0 \\
\hline January & 1976 & 42.2 & 15.1 \\
\hline February & 1976 & 50.0 & 24.3 \\
\hline March & 1976 & 50.7 & 24.1 \\
\hline April & 1976 & 59.0 & 31.8 \\
\hline May & 1976 & 67.4 & 40.4 \\
\hline June & 1976 & 78.9 & 48.8 \\
\hline July & 1976 & 80.3 & 50.9 \\
\hline August & 1976 & 76.3 & 49.3 \\
\hline September & 1976 & 69.1 & 43.7 \\
\hline October & 1976 & 58.6 & 30.2 \\
\hline November & 1976 & 49.6 & 20.8 \\
\hline December & 1976 & 41.4 & 14.5 \\
\hline January & 1977 & 36.3 & 12.3 \\
\hline February & 1977 & 44.9 & 20.1 \\
\hline March & 1977 & 47.9 & 22.4 \\
\hline April & 1977 & 59.0 & 34.8 \\
\hline May & 1977 & 67.9 & 42.9 \\
\hline June & 1977.2 & 53.8 \\
\hline July & 1977.2 & 78.2 & 55.8 \\
\hline August & 1977 & \\
\hline
\end{tabular}




\begin{tabular}{|l|c|r|r|}
\hline \multicolumn{1}{|c|}{ Month } & Year & $\begin{array}{c}\text { Average Max } \\
\left.\text { Temp ( }{ }^{\circ} \mathbf{F}\right)\end{array}$ & $\begin{array}{c}\text { Average Min } \\
\left.\text { Temp ( }{ }^{\circ} \mathbf{F}\right)\end{array}$ \\
\hline September & 1977 & 73.4 & 49.4 \\
\hline October & 1977 & 65.2 & 38.7 \\
\hline November & 1977 & 51.8 & 29.1 \\
\hline December & 1977 & 45.5 & 24.5 \\
\hline January & 1978 & 38.7 & 20.4 \\
\hline February & 1978 & 41.2 & 20.3 \\
\hline March & 1978 & 51.5 & 28.9 \\
\hline April & 1978 & 60.4 & 34.5 \\
\hline May & 1978 & 64.0 & 40.0 \\
\hline June & 1978 & 78.5 & 53.8 \\
\hline July & 1978 & 83.2 & 56.1 \\
\hline August & 1978 & 78.8 & 52.0 \\
\hline September & 1978 & 72.1 & 46.4 \\
\hline October & 1978 & 64.4 & 39.8 \\
\hline November & 1978 & 46.7 & 29.6 \\
\hline December & 1978 & 36.7 & 15.8 \\
\hline January & 1979 & 32.9 & 12.4 \\
\hline February & 1979 & 41.9 & 19.8 \\
\hline March & 1979 & 48.7 & 26.9 \\
\hline April & 1979 & 58.5 & 34.2 \\
\hline May & 1979 & 63.9 & 39.7 \\
\hline June & 1979 & 75.4 & 48.8 \\
\hline July & 1979 & 82.0 & 54.8 \\
\hline August & 1979 & 77.9 & 51.6 \\
\hline September & 1979 & 75.8 & 48.7 \\
\hline October & 1979 & 66.8 & 41.2 \\
\hline November & 1979 & 43.5 & 22.3 \\
\hline December & 1979 & 46.9 & 22.1 \\
\hline January & 1980 & 42.8 & 24.1 \\
\hline February & 1980 & 47.8 & 24.6 \\
\hline March & 1980 & 47.8 & 23.2 \\
\hline April & 1980 & 56.8 & 30.3 \\
\hline May & 1980 & 65.3 & 37.8 \\
\hline June & 1980 & 84.5 & 54.3 \\
\hline July & 1980 & 87.3 & 55.4 \\
\hline August & 1980 & 81.4 & 53.6 \\
\hline September & 1980 & 74.8 & 49.0 \\
\hline January & 1980 & 61.4 & 34.0 \\
\hline
\end{tabular}

\begin{tabular}{|l|c|c|c|}
\hline \multicolumn{1}{|c|}{ Month } & Year & $\begin{array}{c}\text { Average Max } \\
\text { Temp }\left({ }^{\circ} \mathbf{F}\right)\end{array}$ & $\begin{array}{c}\text { Average Min } \\
\text { Temp ( }{ }^{\circ} \text { F) }\end{array}$ \\
\hline February & 1981 & 50.4 & 22.4 \\
\hline March & 1981 & 47.7 & 25.6 \\
\hline April & 1981 & 64.6 & 36.7 \\
\hline May & 1981 & 66.3 & 40.4 \\
\hline June & 1981 & 82.6 & 51.7 \\
\hline July & 1981 & 82.5 & 54.4 \\
\hline August & 1981 & 78.4 & 52.0 \\
\hline September & 1981 & 72.7 & 48.6 \\
\hline October & 1981 & 60.5 & 36.8 \\
\hline November & 1981 & 54.3 & 29.2 \\
\hline December & 1981 & 46.3 & 22.6 \\
\hline January & 1982 & 39.4 & 18.3 \\
\hline February & 1982 & 42.4 & 18.9 \\
\hline March & 1982 & 49.7 & 26.6 \\
\hline April & 1982 & 58.8 & 33.6 \\
\hline May & 1982 & 65.8 & 39.1 \\
\hline June & 1982 & 78.5 & 50.0 \\
\hline July & 1982 & 81.8 & 55.3 \\
\hline August & 1982 & 79.0 & 54.1 \\
\hline September & 1982 & 69.8 & 47.6 \\
\hline October & 1982 & 59.9 & 33.9 \\
\hline November & 1982 & 45.7 & 27.0 \\
\hline December & 1982 & 36.7 & 19.5 \\
\hline January & 1983 & 41.9 & 20.6 \\
\hline February & 1983 & 43.9 & 22.3 \\
\hline March & 1983 & 48.5 & 27.2 \\
\hline April & 1983 & 52.8 & 27.9 \\
\hline May & 1983 & 64.8 & 36.9 \\
\hline June & 1983 & 76.7 & 48.3 \\
\hline July & 1983 & 82.1 & 54.2 \\
\hline August & 1983 & 80.0 & 54.4 \\
\hline September & 1983 & 77.2 & 49.0 \\
\hline October & 1983 & 63.0 & 37.8 \\
\hline November & 1983 & 49.8 & 26.1 \\
\hline December & 1983 & 39.1 & 18.9 \\
\hline January & 1984 & 39.2 & 14.3 \\
\hline February & 1984 & 45.2 & 19.4 \\
\hline March & 1984 & 49.0 & 24.3 \\
\hline April & 1984 & 56.2 & 29.4 \\
\hline May & 1984 & 75.0 & 45.9 \\
\hline June & 1984 & 78.9 & 49.6 \\
\hline
\end{tabular}




\begin{tabular}{|l|c|r|r|}
\hline \multicolumn{1}{|c|}{ Month } & Year & $\begin{array}{c}\text { Average Max } \\
\left.\text { Temp ( }{ }^{\circ} \mathbf{F}\right)\end{array}$ & $\begin{array}{c}\text { Average Min } \\
\left.\text { Temp ( }{ }^{\circ} \mathbf{F}\right)\end{array}$ \\
\hline July & 1984 & 83.5 & 54.6 \\
\hline August & 1984 & 78.9 & 53.1 \\
\hline September & 1984 & 73.1 & 47.1 \\
\hline October & 1984 & 52.7 & 33.0 \\
\hline November & 1984 & 48.7 & 27.1 \\
\hline December & 1984 & 40.2 & 21.8 \\
\hline January & 1985 & 36.9 & 16.7 \\
\hline February & 1985 & 41.4 & 17.4 \\
\hline March & 1985 & 49.1 & 27.4 \\
\hline April & 1985 & 62.0 & 34.8 \\
\hline May & 1985 & 67.3 & 43.1 \\
\hline June & 1985 & 78.7 & 50.9 \\
\hline July & 1985 & 81.7 & 54.4 \\
\hline August & 1985 & 79.2 & 53.3 \\
\hline September & 1985 & 69.1 & 44.0 \\
\hline October & 1985 & 60.9 & 37.0 \\
\hline November & 1985 & 49.4 & 27.1 \\
\hline December & 1985 & 43.8 & 20.0 \\
\hline January & 1986 & 51.1 & 24.1 \\
\hline February & 1986 & 47.8 & 24.1 \\
\hline March & 1986 & 57.1 & 30.4 \\
\hline April & 1986 & 60.5 & 34.7 \\
\hline May & 1986 & 68.0 & 41.2 \\
\hline June & 1986 & 74.5 & 49.5 \\
\hline July & 1986 & 79.9 & 53.3 \\
\hline August & 1986 & 81.3 & 52.6 \\
\hline September & 1986 & 69.8 & 44.2 \\
\hline October & 1986 & 58.0 & 34.7 \\
\hline November & 1986 & 47.1 & 26.6 \\
\hline December & 1986 & 41.2 & 21.1 \\
\hline January & 1987 & 37.1 & 17.2 \\
\hline February & 1987 & 41.3 & 21.6 \\
\hline March & 1987 & 47.9 & 23.5 \\
\hline April & 1987 & 61.0 & 33.5 \\
\hline May & 1987 & 65.4 & 40.5 \\
\hline June & 1987 & 78.6 & 50.9 \\
\hline July & 1987 & 81.9 & 55.8 \\
\hline Sugust & 1987 & 75.3 & 53.3 \\
\hline October & 1987 & 70.5 & 46.9 \\
\hline
\end{tabular}

\begin{tabular}{|l|c|r|r|}
\hline \multicolumn{1}{|c|}{ Month } & Year & $\begin{array}{c}\text { Average Max } \\
\text { Temp ( }{ }^{\circ} \text { F }\end{array}$ & $\begin{array}{c}\text { Average Min } \\
\text { Temp ( }{ }^{\circ} \text { F }\end{array}$ \\
\hline December & 1987 & 36.7 & 17.8 \\
\hline January & 1988 & 35.1 & 14.6 \\
\hline February & 1988 & 46.2 & 22.9 \\
\hline March & 1988 & 50.5 & 24.7 \\
\hline April & 1988 & 60.1 & 33.9 \\
\hline May & 1988 & 66.4 & 40.3 \\
\hline June & 1988 & 77.0 & 51.4 \\
\hline July & 1988 & 79.3 & 54.8 \\
\hline August & 1988 & 74.7 & 54.6 \\
\hline September & 1988 & 69.4 & 47.1 \\
\hline October & 1988 & 65.2 & 41.7 \\
\hline November & 1988 & 48.6 & 26.8 \\
\hline December & 1988 & 39.9 & 17.3 \\
\hline January & 1989 & 38.5 & 17.0 \\
\hline February & 1989 & 43.4 & 21.8 \\
\hline March & 1989 & 58.0 & 31.7 \\
\hline April & 1989 & 66.5 & 38.9 \\
\hline May & 1989 & 73.3 & 46.2 \\
\hline June & 1989 & 78.3 & 51.7 \\
\hline July & 1989 & 81.3 & 55.4 \\
\hline August & 1989 & 76.7 & 52.2 \\
\hline September & 1989 & 73.2 & 47.6 \\
\hline October & 1989 & 61.3 & 36.6 \\
\hline November & 1989 & 52.4 & 27.1 \\
\hline December & 1989 & 40.8 & 17.7 \\
\hline January & 1990 & 38.2 & 16.5 \\
\hline February & 1990 & 41.6 & 20.4 \\
\hline March & 1990 & 51.6 & 29.2 \\
\hline April & 1990 & 59.2 & 35.8 \\
\hline May & 1990 & 66.8 & 42.0 \\
\hline June & 1990 & 84.2 & 55.1 \\
\hline July & 1990 & 76.9 & 53.2 \\
\hline August & 1990 & 76.3 & 50.8 \\
\hline September & 1990 & 72.3 & 48.2 \\
\hline October & 1990 & 62.3 & 36.0 \\
\hline November & 1990 & 48.5 & 26.8 \\
\hline December & 1990 & 34.8 & 13.3 \\
\hline January & 1991 & 34.6 & 14.7 \\
\hline February & 1991 & 45.8 & 23.9 \\
\hline March & 1991 & 46.9 & 25.5 \\
\hline April & 1991 & 59.1 & 31.9 \\
\hline
\end{tabular}




\begin{tabular}{|l|c|r|r|}
\hline \multicolumn{1}{|c|}{ Month } & Year & $\begin{array}{c}\text { Average Max } \\
\left.\text { Temp ( }{ }^{\circ} \mathrm{F}\right)\end{array}$ & $\begin{array}{c}\text { Average Min } \\
\left.\text { Temp ( }{ }^{\circ} \mathbf{F}\right)\end{array}$ \\
\hline May & 1991 & 68.8 & 40.7 \\
\hline June & 1991 & 75.2 & 48.3 \\
\hline July & 1991 & 77.2 & 52.2 \\
\hline August & 1991 & 74.0 & 52.3 \\
\hline September & 1991 & 68.0 & 45.5 \\
\hline October & 1991 & 62.9 & 37.6 \\
\hline November & 1991 & 43.4 & 23.2 \\
\hline December & 1991 & 36.6 & 18.9 \\
\hline January & 1992 & 35.0 & 15.0 \\
\hline February & 1992 & 41.0 & 23.7 \\
\hline March & 1992 & 51.0 & 29.5 \\
\hline April & 1992 & 63.3 & 36.6 \\
\hline May & 1992 & 66.3 & 42.1 \\
\hline June & 1992 & 74.0 & 48.4 \\
\hline July & 1992 & 77.7 & 52.3 \\
\hline August & 1992 & 75.8 & 50.9 \\
\hline September & 1992 & 72.9 & 46.8 \\
\hline October & 1992 & 65.2 & 39.4 \\
\hline November & 1992 & 41.4 & 20.6 \\
\hline December & 1992 & 33.9 & 13.6 \\
\hline January & 1993 & 37.8 & 19.7 \\
\hline February & 1993 & 39.1 & 23.6 \\
\hline March & 1993 & 50.0 & 27.6 \\
\hline April & 1993 & 59.5 & 34.3 \\
\hline May & 1993 & 66.8 & 40.3 \\
\hline June & 1993 & 78.0 & 50.3 \\
\hline July & 1993 & 81.6 & 55.2 \\
\hline August & 1993 & 73.3 & 52.6 \\
\hline September & 1993 & 70.9 & 45.0 \\
\hline October & 1993 & 59.7 & 32.9 \\
\hline November & 1993 & 45.4 & 22.6 \\
\hline December & 1993 & 41.1 & 18.9 \\
\hline January & 1994 & 41.9 & 17.9 \\
\hline February & 1994 & 41.1 & 19.0 \\
\hline March & 1994 & 51.6 & 28.1 \\
\hline April & 1994 & 57.5 & 33.7 \\
\hline May & 1994 & 67.5 & 42.7 \\
\hline June & 82.6 & 55.3 \\
\hline Suly & 82.3 & 55.7 \\
\hline
\end{tabular}

\begin{tabular}{|l|c|r|r|}
\hline \multicolumn{1}{|c|}{ Month } & Year & $\begin{array}{c}\text { Average Max } \\
\text { Temp ( }{ }^{\circ} \text { F) }\end{array}$ & $\begin{array}{c}\text { Average Min } \\
\text { Temp ( }{ }^{\circ} \text { F }\end{array}$ \\
\hline October & 1994 & 59.1 & 34.6 \\
\hline November & 1994 & 46.1 & 24.1 \\
\hline December & 1994 & 43.0 & 22.1 \\
\hline January & 1995 & 37.4 & 18.7 \\
\hline February & 1995 & 50.0 & 28.1 \\
\hline March & 1995 & 50.7 & 27.2 \\
\hline April & 1995 & 55.4 & 30.8 \\
\hline May & 1995 & 63.5 & 39.3 \\
\hline June & 1995 & 73.7 & 48.1 \\
\hline July & 1995 & 80.6 & 54.1 \\
\hline August & 1995 & 79.0 & 54.4 \\
\hline September & 1995 & 71.1 & 46.3 \\
\hline October & 1995 & 66.2 & 35.7 \\
\hline November & 1995 & 53.8 & 27.9 \\
\hline December & 1995 & 42.5 & 21.4 \\
\hline January & 1996 & 39.8 & 18.3 \\
\hline February & 1996 & 48.2 & 24.7 \\
\hline March & 1996 & 51.6 & 25.6 \\
\hline April & 1996 & 62.2 & 34.0 \\
\hline May & 1996 & 77.7 & 48.1 \\
\hline June & 1996 & 80.3 & 53.5 \\
\hline July & 1996 & 78.5 & 55.3 \\
\hline August & 1996 & 77.8 & 53.6 \\
\hline September & 1996 & 68.2 & 43.0 \\
\hline October & 1996 & 57.7 & 34.4 \\
\hline November & 1996 & 49.5 & 27.0 \\
\hline December & 1996 & 42.0 & 18.8 \\
\hline January & 1997 & 35.6 & 15.9 \\
\hline February & 1997 & 39.2 & 20.6 \\
\hline March & 1997 & 55.8 & 27.7 \\
\hline April & 1997 & 53.6 & 29.7 \\
\hline May & 1997 & 67.0 & 42.2 \\
\hline June & 1997 & 75.5 & 49.9 \\
\hline July & 1997 & 80.0 & 54.3 \\
\hline August & 1997 & 76.2 & 53.3 \\
\hline September & 1997 & 72.1 & 49.2 \\
\hline October & 1997 & 60.7 & 34.5 \\
\hline November & 1997 & 45.3 & 24.2 \\
\hline December & 1997 & 35.0 & 15.6 \\
\hline January & 1998 & 40.7 & 20.0 \\
\hline February & 1998 & 40.3 & 21.1 \\
\hline
\end{tabular}




\begin{tabular}{|l|c|c|c|}
\hline \multicolumn{1}{|c|}{ Month } & Year & $\begin{array}{c}\text { Average Max } \\
\left.\text { Temp ( }{ }^{\circ} \mathbf{F}\right)\end{array}$ & $\begin{array}{c}\text { Average Min } \\
\left.\text { Temp ( }{ }^{\circ} \mathbf{F}\right)\end{array}$ \\
\hline March & 1998 & 49.3 & 25.5 \\
\hline April & 1998 & 55.2 & 30.0 \\
\hline May & 1998 & 71.8 & 43.1 \\
\hline June & 1998 & 79.5 & 50.2 \\
\hline July & 1998 & 79.0 & 54.7 \\
\hline August & 1998 & 77.6 & 52.9 \\
\hline September & 1998 & 77.9 & 50.8 \\
\hline October & 1998 & 59.4 & 36.7 \\
\hline November & 1998 & 51.5 & 28.5 \\
\hline December & 1998 & 44.0 & 20.3 \\
\hline January & 1999 & 45.9 & 22.7 \\
\hline February & 1999 & 50.7 & 23.0 \\
\hline March & 1999 & 54.2 & 28.6 \\
\hline April & 1999 & 55.7 & 30.5 \\
\hline May & 1999 & 65.3 & 40.2 \\
\hline June & 1999 & 75.7 & 49.3 \\
\hline July & 1999 & 79.0 & 54.9 \\
\hline August & 1999 & 77.0 & 53.2 \\
\hline September & 1999 & 72.0 & 45.0 \\
\hline October & 1999 & 65.6 & 36.2 \\
\hline November & 1999 & 58.4 & 29.0 \\
\hline December & 1999 & 40.8 & 17.6 \\
\hline January & 2000 & 44.8 & 21.8 \\
\hline February & 2000 & 50.0 & 25.3 \\
\hline March & 2000 & 51.7 & 28.0 \\
\hline April & 2000 & 63.5 & 35.7 \\
\hline May & 2000 & 76.3 & 46.0 \\
\hline June & 2000 & 80.6 & 53.0 \\
\hline July & 2000 & 83.1 & 55.8 \\
\hline August & 2000 & 81.8 & 55.6 \\
\hline September & 2000 & 77.3 & 50.9 \\
\hline October & 2000 & 57.0 & 38.1 \\
\hline November & 2000 & 39.4 & 21.9 \\
\hline December & 2000 & 39.6 & 21.0 \\
\hline January & 2001 & 35.2 & 17.1 \\
\hline February & 2001 & 41.9 & 23.5 \\
\hline March & 2001 & 49.4 & 28.4 \\
\hline June & 2001 & 83.0 & 36.3 \\
\hline
\end{tabular}

\begin{tabular}{|l|c|c|c|}
\hline \multicolumn{1}{|c|}{ Month } & Year & $\begin{array}{c}\text { Average Max } \\
\text { Temp ( }{ }^{\circ} \text { F }\end{array}$ & $\begin{array}{c}\text { Average Min } \\
\text { Temp ( }{ }^{\circ} \text { F }\end{array}$ \\
\hline August & 2001 & 77.9 & 53.1 \\
\hline September & 2001 & 76.9 & 48.6 \\
\hline October & 2001 & 66.2 & 38.1 \\
\hline November & 2001 & 51.1 & 29.5 \\
\hline December & 2001 & 39.7 & 18.5 \\
\hline January & 2002 & 40.5 & 19.1 \\
\hline February & 2002 & 43.6 & 19.2 \\
\hline March & 2002 & 53.2 & 23.8 \\
\hline April & 2002 & 67.1 & 38.3 \\
\hline May & 2002 & 73.3 & 44.5 \\
\hline June & 2002 & 84.5 & 55.4 \\
\hline July & 2002 & 82.5 & 55.8 \\
\hline August & 2002 & 82.7 & 55.1 \\
\hline September & 2002 & 71.4 & 47.7 \\
\hline October & 2002 & 58.8 & 36.1 \\
\hline November & 2002 & 46.6 & 27.0 \\
\hline December & 2002 & 37.2 & 19.0 \\
\hline January & 2003 & 47.6 & 26.8 \\
\hline February & 2003 & 42.2 & 22.7 \\
\hline March & 2003 & 50.9 & 27.8 \\
\hline April & 2003 & 60.6 & 34.4 \\
\hline May & 2003 & 71.7 & 44.0 \\
\hline June & 2003 & 78.9 & 50.3 \\
\hline July & 2003 & 88.5 & 59.3 \\
\hline August & 2003 & 80.4 & 55.0 \\
\hline September & 2003 & 74.3 & 47.6 \\
\hline October & 2003 & 66.9 & 41.2 \\
\hline November & 2003 & 49.2 & 26.2 \\
\hline December & 2003 & 41.2 & 20.5 \\
\hline January & 2004 & 40.7 & 20.5 \\
\hline February & 2004 & 36.0 & 17.2 \\
\hline March & 2004 & 56.3 & 32.7 \\
\hline April & 2004 & 55.9 & 34.2 \\
\hline May & 2004 & 72.1 & 45.4 \\
\hline June & 2004 & 79.5 & 52.1 \\
\hline July & 2004 & 81.1 & 54.5 \\
\hline August & 2004 & 76.8 & 52.5 \\
\hline September & 2004 & 72.5 & 46.1 \\
\hline October & 2004 & 58.7 & 36.9 \\
\hline November & 2004 & 45.0 & 26.8 \\
\hline December & 2004 & 40.1 & 19.9 \\
\hline
\end{tabular}




\begin{tabular}{|l|c|c|c|}
\hline \multicolumn{1}{|c|}{ Month } & Year & $\begin{array}{c}\text { Average Max } \\
\left.\text { Temp ( }{ }^{\circ} \mathrm{F}\right)\end{array}$ & $\begin{array}{c}\text { Average Min } \\
\left.\text { Temp ( }{ }^{\circ} \mathbf{F}\right)\end{array}$ \\
\hline January & 2005 & 43.0 & 25.0 \\
\hline February & 2005 & 41.5 & 25.8 \\
\hline March & 2005 & 46.6 & 26.9 \\
\hline April & 2005 & 59.5 & 34.4 \\
\hline May & 2005 & 69.1 & 45.0 \\
\hline June & 2005 & 79.4 & 50.9 \\
\hline July & 2005 & 86.1 & 56.5 \\
\hline August & 2005 & 76.7 & 53.3 \\
\hline September & 2005 & 73.3 & 49.9 \\
\hline October & 2005 & 59.5 & 38.3 \\
\hline November & 2005 & 52.9 & 29.8 \\
\hline December & 2005 & 43.3 & 20.1 \\
\hline January & 2006 & 44.8 & 21.4 \\
\hline February & 2006 & 48.8 & 22.5 \\
\hline March & 2006 & 50.7 & 28.3 \\
\hline April & 2006 & 65.3 & 37.4 \\
\hline May & 2006 & 74.2 & 46.7 \\
\hline June & 2006 & 82.5 & 54.8 \\
\hline July & 2006 & 81.1 & 56.4 \\
\hline August & 2006 & 73.8 & 54.5 \\
\hline September & 2006 & 66.7 & 44.1 \\
\hline October & 2006 & 59.8 & 36.9 \\
\hline November & 2006 & 51.8 & 29.0 \\
\hline December & 2006 & 38.1 & 20.3 \\
\hline January & 2007 & 34.1 & 16.3 \\
\hline February & 2007 & 41.4 & 22.1 \\
\hline March & 2007 & 55.9 & 31.3 \\
\hline April & 2007 & 59.4 & 33.6 \\
\hline May & 2007 & 67.1 & 42.2 \\
\hline June & 2007 & 79.3 & 51.7 \\
\hline July & 2007 & 83.7 & 56.0 \\
\hline August & 2007 & 83.7 & 56.6 \\
\hline September & 2007 & 72.1 & 49.3 \\
\hline October & 2007 & 64.5 & 39.2 \\
\hline November & 2007 & 53.8 & 29.7 \\
\hline December & 2007 & 36.3 & 18.8 \\
\hline January & 2008 & 33.1 & 14.3 \\
\hline Mebruary & 2008 & 42.8 & 22.4 \\
\hline March & 2008 & 52.1 & 27.6 \\
\hline
\end{tabular}

\begin{tabular}{|l|c|c|c|}
\hline \multicolumn{1}{|c|}{ Month } & Year & $\begin{array}{c}\text { Average Max } \\
\text { Temp }\left({ }^{\circ} \mathbf{F}\right)\end{array}$ & $\begin{array}{c}\text { Average Min } \\
\text { Temp ( }{ }^{\circ} \text { F) }\end{array}$ \\
\hline June & 2008 & 81.1 & 52.7 \\
\hline July & 2008 & 80.4 & 54.6 \\
\hline August & 2008 & 77.6 & 54.3 \\
\hline September & 2008 & 72.8 & 48.2 \\
\hline October & 2008 & 62.9 & 38.2 \\
\hline November & 2008 & 52.3 & 28.7 \\
\hline December & 2008 & 39.0 & 20.3 \\
\hline January & 2009 & 41.6 & 21.9 \\
\hline February & 2009 & 48.3 & 25.7 \\
\hline March & 2009 & 53.2 & 29.0 \\
\hline April & 2009 & 58.5 & 33.9 \\
\hline May & 2009 & 71.3 & 45.9 \\
\hline June & 2009 & 73.6 & 50.6 \\
\hline July & 2009 & 81.4 & 56.0 \\
\hline August & 2009 & 80.4 & 54.0 \\
\hline September & 2009 & 70.6 & 46.4 \\
\hline October & 2009 & 57.6 & 35.5 \\
\hline November & 2009 & 53.3 & 30.1 \\
\hline December & 2009 & 33.0 & 14.9 \\
\hline January & 2010 & 37.3 & 18.0 \\
\hline February & 2010 & 36.0 & 18.5 \\
\hline March & 2010 & 47.7 & 26.2 \\
\hline April & 2010 & 59.5 & 34.3 \\
\hline May & 2010 & 68.5 & 41.5 \\
\hline June & 2010 & 82.4 & 55.0 \\
\hline July & 2010 & 81.5 & 56.9 \\
\hline August & 2010 & 78.7 & 54.1 \\
\hline September & 2010 & 78.5 & 51.1 \\
\hline October & 2010 & 63.2 & 39.6 \\
\hline November & 2010 & 48.8 & 25.1 \\
\hline December & 2010 & 44.5 & 25.2 \\
\hline January & 2011 & 39.9 & 18.0 \\
\hline February & 2011 & 41.3 & 17.8 \\
\hline March & 2011 & 58.1 & 32.0 \\
\hline April & 2011 & 62.4 & 35.5 \\
\hline May & 2011 & 68.2 & 40.2 \\
\hline June & 2011 & 84.6 & 55.5 \\
\hline July & 2011 & 86.3 & 58.7 \\
\hline August & 2011 & 82.9 & 58.3 \\
\hline September & 2011 & 70.8 & 49.2 \\
\hline October & 2011 & 60.8 & 38.4 \\
\hline & & & \\
\hline
\end{tabular}




\begin{tabular}{|c|c|c|c|}
\hline Month & Year & $\begin{array}{c}\text { Average Max } \\
\left.\text { Temp ( }{ }^{\circ} \mathrm{F}\right)\end{array}$ & $\begin{array}{c}\text { Average Min } \\
\left.\text { Temp ( }{ }^{\circ} \mathrm{F}\right)\end{array}$ \\
\hline November & 2011 & 49.1 & 28.0 \\
\hline December & 2011 & 35.1 & 17.6 \\
\hline January & 2012 & 42.0 & 23.2 \\
\hline February & 2012 & 41.9 & 21.9 \\
\hline March & 2012 & 57.2 & 31.6 \\
\hline April & 2012 & 64.8 & 38.8 \\
\hline May & 2012 & 72.9 & 46.5 \\
\hline June & 2012 & 86.6 & 56.9 \\
\hline July & 2012 & 84.2 & 57.2 \\
\hline August & 2012 & 83.4 & 56.1 \\
\hline September & 2012 & 74.7 & 49.3 \\
\hline October & 2012 & 65.6 & 39.6 \\
\hline November & 2012 & 54.3 & 31.0 \\
\hline December & 2012 & 39.4 & 19.0 \\
\hline January & 2013 & 35.5 & 15.4 \\
\hline February & 2013 & 41.3 & 20.2 \\
\hline March & 2013 & 55.5 & 29.7 \\
\hline April & 2013 & 61.7 & 34.9 \\
\hline May & 2013 & 70.4 & 43.2 \\
\hline June & 2013 & 84.9 & 55.9 \\
\hline July & 2013 & 80.4 & 56.2 \\
\hline August & 2013 & 79.8 & 55.6 \\
\hline September & 2013 & 71.4 & 49.7 \\
\hline October & 2013 & 58.6 & 36.0 \\
\hline November & 2013 & 46.3 & 27.7 \\
\hline December & 2013 & 38.5 & 20.1 \\
\hline January & 2014 & 43.2 & 21.3 \\
\hline February & 2014 & 48.7 & 26.2 \\
\hline March & 2014 & 52.9 & 28.9 \\
\hline April & 2014 & 59.4 & 33.6 \\
\hline May & 2014 & 67.9 & 42.4 \\
\hline June & 2014 & 82.5 & 54.1 \\
\hline July & 2014 & 79.6 & 56.3 \\
\hline August & 2014 & 77.0 & 54.0 \\
\hline September & 2014 & 77.3 & 51.2 \\
\hline October & 2014 & 66.7 & 41.4 \\
\hline November & 2014 & 50.9 & 27.0 \\
\hline December & 2014 & 42.0 & 23.3 \\
\hline January & 2015 & 41.7 & 22.6 \\
\hline February & 2015 & 47.8 & 25.4 \\
\hline March & 2015 & 58.2 & 33.6 \\
\hline
\end{tabular}

\begin{tabular}{|l|r|r|r|}
\hline \multicolumn{1}{|c|}{ Month } & Year & $\begin{array}{r}\text { Average Max } \\
\left.\text { Temp ( }{ }^{\circ} \mathbf{F}\right)\end{array}$ & $\begin{array}{c}\text { Average Min } \\
\left.\text { Temp ( }{ }^{\circ} \mathbf{F}\right)\end{array}$ \\
\hline April & 2015 & 62.0 & 37.0 \\
\hline May & 2015 & 64.7 & 41.7 \\
\hline June & 2015 & 80.7 & 55.3 \\
\hline July & 2015 & 78.2 & 55.8 \\
\hline August & 2015 & 80.1 & 56.4 \\
\hline September & 2015 & 78.6 & 52.8 \\
\hline October & 2015 & 64.5 & 42.8 \\
\hline November & 2015 & 49.9 & 28.5 \\
\hline December & 2015 & 39.9 & 22.4 \\
\hline
\end{tabular}




\section{Los Alamos Precipitation}

Data is for tower laarc. This file was obtained from the LANL Weather Machine http://weather.lanl.gov. Request made on Thursday, July 14 09:15:33 2016 MST.

\begin{tabular}{|c|c|c|c|c|}
\hline Day & Month & Year & $\begin{array}{c}\text { Total Precip } \\
\text { (inches) }\end{array}$ & $\begin{array}{c}\text { Total Snow } \\
\text { (inches) }\end{array}$ \\
\hline 31 & January & 1951 & 0.9 & 12.8 \\
\hline 28 & February & 1951 & 0.76 & 5.1 \\
\hline 31 & March & 1951 & 0.39 & 3.1 \\
\hline 30 & April & 1951 & 1.46 & 4.3 \\
\hline 31 & May & 1951 & 1.03 & 0 \\
\hline 30 & June & 1951 & 0 & 0 \\
\hline 31 & July & 1951 & 3.21 & 0 \\
\hline 31 & August & 1951 & 4.51 & 0 \\
\hline 30 & September & 1951 & 0.52 & 0 \\
\hline 31 & October & 1951 & 1.56 & 0 \\
\hline 30 & November & 1951 & 0.12 & 2.5 \\
\hline 31 & December & 1951 & 0.82 & 8.7 \\
\hline 31 & January & 1952 & 1.88 & 5.5 \\
\hline 29 & February & 1952 & 0.36 & 2.3 \\
\hline 31 & March & 1952 & 1.19 & 10.1 \\
\hline 30 & April & 1952 & 1.21 & 0.9 \\
\hline 31 & May & 1952 & 3.5 & 4 \\
\hline 30 & June & 1952 & 1.3 & 0 \\
\hline 31 & July & 1952 & 4.02 & 0 \\
\hline 31 & August & 1952 & 11.18 & 0 \\
\hline 30 & September & 1952 & 1.53 & 0 \\
\hline 31 & October & 1952 & 0 & 0 \\
\hline 30 & November & 1952 & 1.58 & 9 \\
\hline 31 & December & 1952 & 1.56 & 7.9 \\
\hline 31 & January & 1953 & 0.11 & 1.4 \\
\hline 28 & February & 1953 & 0.75 & 8.2 \\
\hline 31 & March & 1953 & 0.9 & 5.7 \\
\hline 30 & April & 1953 & 0.28 & 0 \\
\hline 31 & May & 1953 & 1.58 & 0.6 \\
\hline 30 & June & 1953 & 1.19 & 0 \\
\hline 31 & July & 1953 & 3.37 & 0 \\
\hline 31 & August & 1953 & 3.86 & 0 \\
\hline 30 & September & 1953 & 0 & 0 \\
\hline 31 & October & 1953 & 2.12 & 0 \\
\hline 30 & November & 1953 & 1.92 & 6 \\
\hline 31 & December & 1953 & 0.62 & 8.2 \\
\hline 31 & January & 1954 & 0.55 & 11.7 \\
\hline
\end{tabular}

\begin{tabular}{|c|c|c|c|c|}
\hline Day & Month & \begin{tabular}{|l|} 
Year \\
\end{tabular} & $\begin{array}{c}\text { Total Precip } \\
\text { (inches) }\end{array}$ & $\begin{array}{c}\text { Total Snow } \\
\text { (inches) }\end{array}$ \\
\hline 28 & February & 1954 & 0 & 0.5 \\
\hline 31 & March & 1954 & 1 & 2.9 \\
\hline 30 & April & 1954 & 0 & 0 \\
\hline 31 & May & 1954 & 1.99 & 0 \\
\hline 30 & June & 1954 & 0.21 & 0 \\
\hline 31 & July & 1954 & 5.46 & 0 \\
\hline 31 & August & 1954 & 2.12 & 0 \\
\hline 30 & September & 1954 & 1.8 & 0 \\
\hline 31 & October & 1954 & 1.64 & 0 \\
\hline 30 & November & 1954 & 0.06 & 0 \\
\hline 31 & December & 1954 & 0.57 & 11.5 \\
\hline 31 & January & 1955 & 0.75 & 6.9 \\
\hline 28 & February & 1955 & 0.33 & 3.8 \\
\hline 31 & March & 1955 & 0.17 & 1.5 \\
\hline 30 & April & 1955 & 0.66 & 3 \\
\hline 31 & May & 1955 & 1.9 & 0 \\
\hline 30 & June & 1955 & 0.11 & 0 \\
\hline 31 & July & 1955 & 2.39 & 0 \\
\hline 31 & August & 1955 & 4.37 & 0 \\
\hline 30 & September & 1955 & 1.02 & 0 \\
\hline 31 & October & 1955 & 0.08 & 0 \\
\hline 30 & November & 1955 & 0.13 & 1.5 \\
\hline 31 & December & 1955 & 0.54 & 8.5 \\
\hline 31 & January & 1956 & 0.77 & 19 \\
\hline 29 & February & 1956 & 0.81 & 18 \\
\hline 31 & March & 1956 & 0.02 & 0.5 \\
\hline 30 & April & 1956 & 0.17 & 1 \\
\hline 31 & May & 1956 & 0.67 & 0 \\
\hline 30 & June & 1956 & 1.77 & 0 \\
\hline 31 & July & 1956 & 0.72 & 0 \\
\hline 31 & August & 1956 & 1.55 & 0 \\
\hline 30 & September & 1956 & 0 & 0 \\
\hline 31 & October & 1956 & 0.23 & 0 \\
\hline 30 & November & 1956 & 0 & 0.5 \\
\hline 31 & December & 1956 & 0.09 & 2.5 \\
\hline 31 & January & 1957 & 1.5 & 7.5 \\
\hline 28 & February & 1957 & 0.52 & 2.1 \\
\hline
\end{tabular}




\begin{tabular}{|c|c|c|c|c|}
\hline Day & Month & Year & $\begin{array}{c}\text { Total Precip } \\
\text { (inches) }\end{array}$ & $\begin{array}{c}\text { Total Snow } \\
\text { (inches) }\end{array}$ \\
\hline 31 & March & 1957 & 1.44 & 12.5 \\
\hline 30 & April & 1957 & 0.48 & 6.1 \\
\hline 31 & May & 1957 & 1.3 & 0 \\
\hline 30 & June & 1957 & 0.63 & 0 \\
\hline 31 & July & 1957 & 3.94 & 0 \\
\hline 31 & August & 1957 & 7.89 & 0.4 \\
\hline 30 & September & 1957 & 0.15 & 0 \\
\hline 31 & October & 1957 & 6.77 & 0.1 \\
\hline 30 & November & 1957 & 3.3 & 34.5 \\
\hline 31 & December & 1957 & 0.11 & 4 \\
\hline 31 & January & 1958 & 0.52 & 13 \\
\hline 28 & February & 1958 & 0.43 & 2.6 \\
\hline 31 & March & 1958 & 2.33 & 35.5 \\
\hline 30 & April & 1958 & 2.38 & 33.6 \\
\hline 31 & May & 1958 & 1.37 & 0.3 \\
\hline 30 & June & 1958 & 1.14 & 0 \\
\hline 31 & July & 1958 & 1.58 & 0 \\
\hline 31 & August & 1958 & 2.68 & 0 \\
\hline 30 & September & 1958 & 2.93 & 0 \\
\hline 31 & October & 1958 & 0.75 & 0.3 \\
\hline 30 & November & 1958 & 0.35 & 6.2 \\
\hline 31 & December & 1958 & 0.27 & 8.5 \\
\hline 31 & January & 1959 & 0.13 & 1.2 \\
\hline 28 & February & 1959 & 0.69 & 10.9 \\
\hline 31 & March & 1959 & 0.53 & 8 \\
\hline 30 & April & 1959 & 0.95 & 4 \\
\hline 31 & May & 1959 & 0.98 & 0 \\
\hline 30 & June & 1959 & 1.58 & 0 \\
\hline 31 & July & 1959 & 2.5 & 0 \\
\hline 31 & August & 1959 & 7.24 & 0 \\
\hline 30 & September & 1959 & 0.08 & 0 \\
\hline 31 & October & 1959 & 4.62 & 9 \\
\hline 30 & November & 1959 & 0.65 & 4 \\
\hline 31 & December & 1959 & 1.6 & 28 \\
\hline 31 & January & 1960 & 1.11 & 20.5 \\
\hline 29 & February & 1960 & 0.68 & 15.5 \\
\hline 31 & March & 1960 & 1.03 & 11.4 \\
\hline 30 & April & 1960 & 0.03 & 0 \\
\hline 31 & May & 1960 & 0.4 & 0.2 \\
\hline 30 & June & 1960 & 3.4 & 0 \\
\hline 31 & July & 1960 & 2.47 & 0 \\
\hline
\end{tabular}

\begin{tabular}{|c|c|c|c|c|}
\hline Day & Month & Year & $\begin{array}{c}\text { Total Precip } \\
\text { (inches) }\end{array}$ & $\begin{array}{l}\text { Total Snow } \\
\text { (inches) }\end{array}$ \\
\hline 31 & August & 1960 & 2.08 & 0 \\
\hline 30 & September & 1960 & 1.3 & 0 \\
\hline 31 & October & 1960 & 3.72 & 8 \\
\hline 30 & November & 1960 & 0.46 & 0.5 \\
\hline 31 & December & 1960 & 1.76 & 31.2 \\
\hline 31 & January & 1961 & 0.35 & 6 \\
\hline 28 & February & 1961 & 0.65 & 9.3 \\
\hline 31 & March & 1961 & 2.19 & 17.3 \\
\hline 30 & April & 1961 & 1.91 & 14 \\
\hline 31 & May & 1961 & 0.3 & 0 \\
\hline 30 & June & 1961 & 0.68 & 0 \\
\hline 31 & July & 1961 & 2.04 & 0 \\
\hline 31 & August & 1961 & 5.29 & 0 \\
\hline 30 & September & 1961 & 1.27 & 0 \\
\hline 31 & October & 1961 & 1.96 & 2 \\
\hline 30 & November & 1961 & 0.99 & 8.2 \\
\hline 31 & December & 1961 & 2.59 & 33.2 \\
\hline 31 & January & 1962 & 1.35 & 14.4 \\
\hline 28 & February & 1962 & 0.19 & 1.3 \\
\hline 31 & March & 1962 & 0.58 & 6.6 \\
\hline 30 & April & 1962 & 0.54 & 0.1 \\
\hline 31 & May & 1962 & 0.05 & 0.2 \\
\hline 30 & June & 1962 & 0.34 & 0 \\
\hline 31 & July & 1962 & 4.81 & 0 \\
\hline 31 & August & 1962 & 1.1 & 0 \\
\hline 30 & September & 1962 & 2.92 & 0 \\
\hline 31 & October & 1962 & 0.83 & 0 \\
\hline 30 & November & 1962 & 1.18 & 5.5 \\
\hline 31 & December & 1962 & 1.59 & 12.5 \\
\hline 31 & January & 1963 & 1.04 & 12.2 \\
\hline 28 & February & 1963 & 1.78 & 18.6 \\
\hline 31 & March & 1963 & 1.21 & 15.1 \\
\hline 30 & April & 1963 & 0.41 & 0 \\
\hline 31 & May & 1963 & 0.23 & 0 \\
\hline 30. & June & 1963 & 1.24 & 0 \\
\hline 31 & July & 1963 & 2.91 & 0 \\
\hline 31 & August & 1963 & 4.78 & 0 \\
\hline 30 & September & 1963 & 1.98 & 0 \\
\hline 31 & October & 1963 & 1.56 & 0 \\
\hline 30 & November & 1963 & 0.66 & 5 \\
\hline 31 & December & 1963 & 0.02 & 0.2 \\
\hline
\end{tabular}




\begin{tabular}{|c|c|c|c|c|}
\hline Day & Month & Year & $\begin{array}{c}\text { Total Precip } \\
\text { (inches) }\end{array}$ & $\begin{array}{c}\text { Total Snow } \\
\text { (inches) }\end{array}$ \\
\hline 31 & January & 1964 & 0.64 & 6.7 \\
\hline 29 & February & 1964 & 1.87 & 19.2 \\
\hline 31 & March & 1964 & 0.52 & 6.2 \\
\hline 30 & April & 1964 & 1.02 & 8 \\
\hline 31 & May & 1964 & 0.67 & 0 \\
\hline 30 & June & 1964 & 0.26 & 0 \\
\hline 31 & July & 1964 & 1.9 & 0 \\
\hline 31 & August & 1964 & 1.07 & 0 \\
\hline 30 & September & 1964 & 1.49 & 0 \\
\hline 31 & October & 1964 & 0.03 & 0 \\
\hline 30 & November & 1964 & 1.08 & 7 \\
\hline 31 & December & 1964 & 0.71 & 8.6 \\
\hline 31 & January & 1965 & 1.35 & 9.8 \\
\hline 28 & February & 1965 & 1.15 & 16.7 \\
\hline 31 & March & 1965 & 0.56 & 5.5 \\
\hline 30 & April & 1965 & 1.72 & 4.2 \\
\hline 31 & May & 1965 & 1.13 & 0 \\
\hline 30 & June & 1965 & 2 & 0 \\
\hline 31 & July & 1965 & 2.25 & 0 \\
\hline 31 & August & 1965 & 5.51 & 0 \\
\hline 30 & September & 1965 & 2.86 & 0 \\
\hline 31 & October & 1965 & 1.32 & 1.3 \\
\hline 30 & November & 1965 & 1 & 0 \\
\hline 31 & December & 1965 & 2.85 & 15.3 \\
\hline 31 & January & 1966 & 0.39 & 5.3 \\
\hline 28 & February & 1966 & 1.3 & 11.4 \\
\hline 31 & March & 1966 & 0.1 & 0.7 \\
\hline 30 & April & 1966 & 0.03 & 0.3 \\
\hline 31 & May & 1966 & 0.46 & 0 \\
\hline 30 & June & 1966 & 2.83 & 0 \\
\hline 31 & July & 1966 & 4.13 & 0 \\
\hline 31 & August & 1966 & 5.05 & 0 \\
\hline 30 & September & 1966 & 1.11 & 0 \\
\hline 31 & October & 1966 & 0.46 & 0.7 \\
\hline 30 & November & 1966 & 0.48 & 3.5 \\
\hline 31 & December & 1966 & 1.14 & 7 \\
\hline 31 & January & 1967 & 0.11 & 1.3 \\
\hline 28 & February & 1967 & 0.33 & 2.8 \\
\hline 31 & March & 1967 & 0.42 & 1.5 \\
\hline 30 & April & 1967 & 0 & 0 \\
\hline 31 & May & 1967 & 0.73 & 0 \\
\hline
\end{tabular}

\begin{tabular}{|c|c|c|c|c|}
\hline Day & Month & Year & $\begin{array}{c}\text { Total Precip } \\
\text { (inches) }\end{array}$ & $\begin{array}{c}\text { Total Snow } \\
\text { (inches) }\end{array}$ \\
\hline 30 & June & 1967 & 1.55 & 0 \\
\hline 31 & July & 1967 & 5.68 & 0 \\
\hline 31 & August & 1967 & 6.42 & 0 \\
\hline 30 & September & 1967 & 2.41 & 0 \\
\hline 31 & October & 1967 & 0.25 & 2 \\
\hline 30 & November & 1967 & 0.21 & 2.1 \\
\hline 31 & December & 1967 & 2.69 & 41.3 \\
\hline 31 & January & 1968 & 0.15 & 1.8 \\
\hline 29 & February & 1968 & 0.92 & 11.7 \\
\hline 31 & March & 1968 & 1.1 & 12.7 \\
\hline 30 & April & 1968 & 0.46 & 5.4 \\
\hline 31 & May & 1968 & 2.08 & 0 \\
\hline 30 & June & 1968 & 0.03 & 0 \\
\hline 31 & July & 1968 & 6.6 & 0 \\
\hline 31 & August & 1968 & 6.39 & 0 \\
\hline 30 & September & 1968 & 0.38 & 0 \\
\hline 31 & October & 1968 & 0.45 & 0 \\
\hline 30 & November & 1968 & 0.57 & 1.7 \\
\hline 31 & December & 1968 & 0.43 & 7.2 \\
\hline 31 & January & 1969 & 1.08 & 6 \\
\hline 28 & February & 1969 & 0.91 & 10.2 \\
\hline 31 & March & 1969 & 1.04 & 21.4 \\
\hline 30 & April & 1969 & 1.99 & 5.9 \\
\hline 31 & May & 1969 & 1.53 & 1.5 \\
\hline 30 & June & 1969 & 3.29 & 0 \\
\hline 31 & July & 1969 & 4.44 & 0 \\
\hline 31 & August & 1969 & 2.91 & 0 \\
\hline 30 & September & 1969 & 3.77 & 0 \\
\hline 31 & October & 1969 & 3.62 & 5 \\
\hline 30 & November & 1969 & 0.33 & 3 \\
\hline 31 & December & 1969 & 0.76 & 11.5 \\
\hline 31 & January & 1970 & 0.06 & 1.5 \\
\hline 28 & February & 1970 & 0.25 & 3.2 \\
\hline 31 & March & 1970 & 2.05 & 22.4 \\
\hline 30 & April & 1970 & 0.2 & 1.7 \\
\hline 31 & May & 1970 & 0.31 & 0.5 \\
\hline 30. & June & 1970 & 1.56 & 0 \\
\hline 31. & July & 1970 & 2.49 & 0 \\
\hline 31 & August & 1970 & 5.6 & 0 \\
\hline 30 & September & 1970 & 1.7 & 0.2 \\
\hline 31 & October & 1970 & 0.42 & 1.4 \\
\hline
\end{tabular}




\begin{tabular}{|c|c|c|c|c|}
\hline Day & Month & Year & $\begin{array}{c}\text { Total Precip } \\
\text { (inches) }\end{array}$ & $\begin{array}{c}\text { Total Snow } \\
\text { (inches) }\end{array}$ \\
\hline 30 & November & 1970 & 0.23 & 0 \\
\hline 31 & December & 1970 & 0.06 & 0.9 \\
\hline 31 & January & 1971 & 0.81 & 10.5 \\
\hline 28 & February & 1971 & 0.25 & 4 \\
\hline 31 & March & 1971 & 0.32 & 5.9 \\
\hline 30 & April & 1971 & 0.48 & 3.6 \\
\hline 31 & May & 1971 & 0.21 & 0 \\
\hline 30 & June & 1971 & 0.4 & 0 \\
\hline 31 & July & 1971 & 4.83 & 0 \\
\hline 31 & August & 1971 & 2.89 & 0 \\
\hline 30 & September & 1971 & 2.48 & 1.5 \\
\hline 31 & October & 1971 & 3.02 & 0.7 \\
\hline 30 & November & 1971 & 0.79 & 4.9 \\
\hline 31 & December & 1971 & 2.8 & 35.8 \\
\hline 31 & January & 1972 & 0.24 & 3.6 \\
\hline 29 & February & 1972 & 0.04 & 0.6 \\
\hline 31 & March & 1972 & 0.09 & 0.5 \\
\hline 30 & April & 1972 & 0.02 & 0 \\
\hline 31 & May & 1972 & 0.96 & 0 \\
\hline 30 & June & 1972 & 1.66 & 0 \\
\hline 31 & July & 1972 & 2.6 & 0 \\
\hline 31 & August & 1972 & 2.76 & 0 \\
\hline 30 & September & 1972 & 3.77 & 0 \\
\hline 31 & October & 1972 & 2.9 & 9 \\
\hline 30 & November & 1972 & 1.15 & 14.5 \\
\hline 31 & December & 1972 & 0.8 & 1 \\
\hline 31 & January & 1973 & 0.23 & 3.8 \\
\hline 28 & February & 1973 & 0.69 & 9 \\
\hline 31 & March & 1973 & 4.11 & 37 \\
\hline 30 & April & 1973 & 0.4 & 4 \\
\hline 31 & May & 1973 & 1.58 & 0 \\
\hline 30 & June & 1973 & 0.47 & 0 \\
\hline 31 & July & 1973 & 3.28 & 0 \\
\hline 31 & August & 1973 & 1.2 & 0 \\
\hline 30 & September & 1973 & 2.21 & 0 \\
\hline 31 & October & 1973 & 0.45 & 0 \\
\hline 30 & November & 1973 & 0.3 & 1.5 \\
\hline 31 & December & 1973 & 0.06 & 1 \\
\hline 31 & January & 1974 & 1.55 & 23.2 \\
\hline 28 & February & 1974 & 0.36 & 3.6 \\
\hline 31 & March & 1974 & 1.11 & 7 \\
\hline
\end{tabular}

\begin{tabular}{|c|c|c|c|c|}
\hline Day & Month & Year & $\begin{array}{c}\text { Total Precip } \\
\text { (inches) }\end{array}$ & $\begin{array}{l}\text { Total Snow } \\
\text { (inches) }\end{array}$ \\
\hline 30 & April & 1974 & 0.45 & 3.5 \\
\hline 31 & May & 1974 & 0.11 & 0 \\
\hline 30 & June & 1974 & 0.88 & 0 \\
\hline 31 & July & 1974 & 3.38 & 0 \\
\hline 31 & August & 1974 & 3.94 & 0 \\
\hline 30 & September & 1974 & 1.71 & 0 \\
\hline 31 & October & 1974 & 3.86 & 0 \\
\hline 30 & November & 1974 & 0.47 & 0.7 \\
\hline 31 & December & 1974 & 0.87 & 13.2 \\
\hline 31 & January & 1975 & 1.29 & 15.7 \\
\hline 28 & February & 1975 & 1.84 & 23 \\
\hline 31 & March & 1975 & 1.28 & 12 \\
\hline 30 & April & 1975 & 3.23 & 33.2 \\
\hline 31 & May & 1975 & 0.16 & 0 \\
\hline 30 & June & 1975 & 0.35 & 0 \\
\hline 31 & July & 1975 & 3.88 & 0 \\
\hline 31 & August & 1975 & 1.63 & 0 \\
\hline 30 & September & 1975 & 4.55 & 0 \\
\hline 31 & October & 1975 & 0.22 & 0 \\
\hline 30 & November & 1975 & 0.59 & 4 \\
\hline 31 & December & 1975 & 0.3 & 3 \\
\hline 31 & January & 1976 & 0.08 & 1 \\
\hline 29 & February & 1976 & 1.06 & 0 \\
\hline 31 & March & 1976 & 0.69 & 7.3 \\
\hline 30 & April & 1976 & 0.72 & 0 \\
\hline 31 & May & 1976 & 1.08 & 2 \\
\hline 30 & June & 1976 & 0.21 & 0 \\
\hline 31 & July & 1976 & 4.75 & 0 \\
\hline 31 & August & 1976 & 3.03 & 0 \\
\hline 30 & September & 1976 & 1.22 & 0 \\
\hline 31 & October & 1976 & 0.02 & 0 \\
\hline 30 & November & 1976 & 1 & 12 \\
\hline 31 & December & 1976 & 0.09 & 1.2 \\
\hline 31 & January & 1977 & 1.38 & 14.4 \\
\hline 28 & February & 1977 & 0.09 & 1 \\
\hline 31 & March & 1977 & 0.21 & 0 \\
\hline 30 & April & 1977 & 2.34 & 4 \\
\hline 31 & May & 1977 & 1.02 & 0 \\
\hline 30 & June & 1977 & 1.09 & 0 \\
\hline 31 & July & 1977 & 3.35 & 0 \\
\hline 31 & August & 1977 & 5.12 & 0 \\
\hline
\end{tabular}




\begin{tabular}{|c|c|c|c|c|}
\hline Day & Month & \begin{tabular}{|l|} 
Year \\
\end{tabular} & $\begin{array}{c}\text { Total Precip } \\
\text { (inches) }\end{array}$ & $\begin{array}{c}\text { Total Snow } \\
\text { (inches) }\end{array}$ \\
\hline 30 & September & 1977 & 0.4 & 0 \\
\hline 31 & October & 1977 & 0.15 & 0 \\
\hline 30 & November & 1977 & 1.4 & 2 \\
\hline 31 & December & 1977 & 0.14 & 0.8 \\
\hline 31 & January & 1978 & 0.69 & 6 \\
\hline 28 & February & 1978 & 0.28 & 2 \\
\hline 31 & March & 1978 & 1.45 & 5 \\
\hline 30 & April & 1978 & 0.28 & 0 \\
\hline 31 & May & 1978 & 1.99 & 16 \\
\hline 30 & June & 1978 & 1.38 & 0 \\
\hline 31 & July & 1978 & 1.35 & 0 \\
\hline 31 & August & 1978 & 1.39 & 0 \\
\hline 30 & September & 1978 & 1.35 & 0 \\
\hline 31 & October & 1978 & 1.05 & 1 \\
\hline 30 & November & 1978 & 6.6 & 7 \\
\hline 31 & December & 1978 & 2.25 & 25 \\
\hline 31 & January & 1979 & 2.81 & 30.3 \\
\hline 28 & February & 1979 & 0.14 & 1.3 \\
\hline 31 & March & 1979 & 1.27 & 7.5 \\
\hline 30 & April & 1979 & 0.43 & 0 \\
\hline 31 & May & 1979 & 3.1 & 0 \\
\hline 30 & June & 1979 & 2.11 & 0 \\
\hline 31 & July & 1979 & 0.78 & 0 \\
\hline 31 & August & 1979 & 2.33 & 0 \\
\hline 30 & September & 1979 & 0.82 & 0 \\
\hline 31 & October & 1979 & 0.59 & 4 \\
\hline 30 & November & 1979 & 0.48 & 0.7 \\
\hline 31 & December & 1979 & 0.36 & 9 \\
\hline 31 & January & 1980 & 1.55 & 11 \\
\hline 29 & February & 1980 & 0.96 & 2 \\
\hline 31 & March & 1980 & 0.85 & 9.3 \\
\hline 30 & April & 1980 & 1.62 & 12 \\
\hline 31 & May & 1980 & 1.43 & 0 \\
\hline 30 & June & 1980 & 0 & 0 \\
\hline 31 & July & 1980 & 0.35 & 0 \\
\hline 31 & August & 1980 & 1.97 & 0 \\
\hline 30 & September & 1980 & 1.18 & 0 \\
\hline 31 & October & 1980 & 1.04 & 6 \\
\hline 30 & November & 1980 & 0.68 & 8.3 \\
\hline 31 & December & 1980 & 0.33 & 7 \\
\hline 31 & January & 1981 & 0.05 & 1.2 \\
\hline
\end{tabular}

\begin{tabular}{|c|c|c|c|c|}
\hline Day & Month & Year & $\begin{array}{c}\text { Total Precip } \\
\text { (inches) }\end{array}$ & $\begin{array}{c}\text { Total Snow } \\
\text { (inches) }\end{array}$ \\
\hline 28 & February & 1981 & 0.09 & 1.3 \\
\hline 31 & March & 1981 & 2.73 & 29.4 \\
\hline 30 & April & 1981 & 0.75 & 1 \\
\hline 31 & May & 1981 & 2.17 & 0 \\
\hline 30 & June & 1981 & 1.22 & 0 \\
\hline 31 & July & 1981 & 3.36 & 0 \\
\hline 31 & August & 1981 & 2.76 & 0 \\
\hline 30 & September & 1981 & 2.37 & 0 \\
\hline 31 & October & 1981 & 1.37 & 0 \\
\hline 30 & November & 1981 & 0.83 & 1.5 \\
\hline 31 & December & 1981 & 0.01 & 0.2 \\
\hline 31 & January & 1982 & 0.75 & 19.3 \\
\hline 28 & February & 1982 & 1.76 & 36.4 \\
\hline 31 & March & 1982 & 1.33 & 8.2 \\
\hline 30 & April & 1982 & 0.4 & 2 \\
\hline 31 & May & 1982 & 1.95 & 0.5 \\
\hline 30 & June & 1982 & 0.15 & 0 \\
\hline 31 & July & 1982 & 3.76 & 0 \\
\hline 31 & August & 1982 & 4.54 & 0 \\
\hline 30 & September & 1982 & 2.67 & 0 \\
\hline 31 & October & 1982 & 0.6 & 5 \\
\hline 30 & November & 1982 & 1.7 & 3.8 \\
\hline 31 & December & 1982 & 2.06 & 24.2 \\
\hline 31 & January & 1983 & 1.12 & 17.9 \\
\hline 28 & February & 1983 & 0.63 & 9.8 \\
\hline 31 & March & 1983 & 1.81 & 16.3 \\
\hline 30 & April & 1983 & 0.84 & 11.5 \\
\hline 31 & May & 1983 & 0.65 & 0 \\
\hline 30 & June & 1983 & 0.41 & 0 \\
\hline 31 & July & 1983 & 3.64 & 0 \\
\hline 31 & August & 1983 & 2.99 & 0 \\
\hline 30 & September & 1983 & 1.89 & 0 \\
\hline 31 & October & 1983 & 1.12 & 0 \\
\hline 30 & November & 1983 & 0.48 & 5.2 \\
\hline 31 & December & 1983 & 1.08 & 11.7 \\
\hline 31 & January & 1984 & 0.63 & 14.2 \\
\hline 29 & February & 1984 & 0.14 & 1 \\
\hline 31 & March & 1984 & 2.04 & 34 \\
\hline 30 & April & 1984 & 0.51 & 2.2 \\
\hline 31 & May & 1984 & 0.72 & 0 \\
\hline 30 & June & 1984 & 0.76 & 0 \\
\hline
\end{tabular}




\begin{tabular}{|c|c|c|c|c|}
\hline Day & Month & \begin{tabular}{|l|} 
Year \\
\end{tabular} & $\begin{array}{c}\text { Total Precip } \\
\text { (inches) }\end{array}$ & $\begin{array}{c}\text { Total Snow } \\
\text { (inches) }\end{array}$ \\
\hline 31 & July & 1984 & 2.5 & 0 \\
\hline 31 & August & 1984 & 3.86 & 0 \\
\hline 30 & September & 1984 & 1.69 & 0 \\
\hline 31 & October & 1984 & 3.02 & 20 \\
\hline 30 & November & 1984 & 0.34 & 3.3 \\
\hline 31 & December & 1984 & 3.21 & 37.1 \\
\hline 31 & January & 1985 & 0.57 & 14.3 \\
\hline 28 & February & 1985 & 0.87 & 13.5 \\
\hline 31 & March & 1985 & 3.17 & 28.3 \\
\hline 30 & April & 1985 & 3.1 & 3.5 \\
\hline 31 & May & 1985 & 2.23 & 0 \\
\hline 30 & June & 1985 & 1.87 & 0 \\
\hline 31 & July & 1985 & 2.97 & 0 \\
\hline 31 & August & 1985 & 3.98 & 0 \\
\hline 30 & September & 1985 & 2.78 & 0 \\
\hline 31 & October & 1985 & 2.96 & 0 \\
\hline 30 & November & 1985 & 0.57 & 5.9 \\
\hline 31 & December & 1985 & 0.44 & 10.5 \\
\hline 31 & January & 1986 & 0.01 & 0.2 \\
\hline 28 & February & 1986 & 1.01 & 19 \\
\hline 31 & March & 1986 & 0.76 & 7.2 \\
\hline 30 & April & 1986 & 1.84 & 2.7 \\
\hline 31 & May & 1986 & 1.64 & 2 \\
\hline 30 & June & 1986 & 5.64 & 0 \\
\hline 31 & July & 1986 & 2.18 & 0 \\
\hline 31 & August & 1986 & 3.31 & 0 \\
\hline 30 & September & 1986 & 2.02 & 0 \\
\hline 31 & October & 1986 & 2.94 & 7 \\
\hline 30 & November & 1986 & 2.23 & 5.9 \\
\hline 31 & December & 1986 & 0.44 & 5.2 \\
\hline 31 & January & 1987 & 2.43 & 64.8 \\
\hline 28 & February & 1987 & 2.78 & 48.5 \\
\hline 31 & March & 1987 & 0.88 & 9.3 \\
\hline 30 & April & 1987 & 1.09 & 12.5 \\
\hline 31 & May & 1987 & 2.83 & 0 \\
\hline 30 & June & 1987 & 2.69 & 0 \\
\hline 31 & July & 1987 & 1.37 & 0 \\
\hline 31 & August & 1987 & 4.29 & 0 \\
\hline 30 & September & 1987 & 1.72 & 0 \\
\hline 31 & October & 1987 & 0.49 & 0 \\
\hline 30 & November & 1987 & 1.47 & 7 \\
\hline
\end{tabular}

\begin{tabular}{|c|c|c|c|c|}
\hline Day & Month & Year & $\begin{array}{c}\text { Total Precip } \\
\text { (inches) }\end{array}$ & $\begin{array}{c}\text { Total Snow } \\
\text { (inches) }\end{array}$ \\
\hline 31 & December & 1987 & 1.58 & 36.3 \\
\hline 31 & January & 1988 & 0.95 & 16 \\
\hline 29 & February & 1988 & 0.2 & 1.8 \\
\hline 31 & March & 1988 & 1.1 & 17.9 \\
\hline 30 & April & 1988 & 1.75 & 1.2 \\
\hline 31 & May & 1988 & 1.97 & 0 \\
\hline 30 & June & 1988 & 4.36 & 0 \\
\hline 31 & July & 1988 & 4.71 & 0 \\
\hline 31 & August & 1988 & 4.56 & 0 \\
\hline 30 & September & 1988 & 3.28 & 0 \\
\hline 31 & October & 1988 & 0.54 & 0 \\
\hline 30 & November & 1988 & 0.59 & 6.4 \\
\hline 31 & December & 1988 & 0.32 & 6 \\
\hline 31 & January & 1989 & 1.2 & 16.6 \\
\hline 28 & February & 1989 & 0.99 & 16.3 \\
\hline 31 & March & 1989 & 0.91 & 7.3 \\
\hline 30 & April & 1989 & 0.21 & 0 \\
\hline 31 & May & 1989 & 1.07 & 0 \\
\hline 30 & June & 1989 & 0.51 & 0 \\
\hline 31 & July & 1989 & 3.71 & 0 \\
\hline 31 & August & 1989 & 3.16 & 0 \\
\hline 30 & September & 1989 & 2.14 & 0 \\
\hline 31 & October & 1989 & 1.73 & 0 \\
\hline 30 & November & 1989 & 0.04 & 0.6 \\
\hline 31 & December & 1989 & 0.5 & 10.7 \\
\hline 31 & January & 1990 & 0.97 & 17.5 \\
\hline 28 & February & 1990 & 0.38 & 6.3 \\
\hline 31 & March & 1990 & 0.62 & 1.9 \\
\hline 30 & April & 1990 & 1.5 & 1.2 \\
\hline 31 & May & 1990 & 0.89 & 3 \\
\hline 30 & June & 1990 & 0.93 & 0 \\
\hline 31 & July & 1990 & 3.65 & 0 \\
\hline 31 & August & 1990 & 1.87 & 0 \\
\hline 30 & September & 1990 & 3.37 & 0 \\
\hline 31 & October & 1990 & 0.66 & 0 \\
\hline 30 & November & 1990 & 2.08 & 5.5 \\
\hline 31 & December & 1990 & 1.79 & 10.5 \\
\hline 31 & January & 1991 & 0.39 & 7.5 \\
\hline 28 & February & 1991 & 0.34 & 3.3 \\
\hline 31 & March & 1991 & 1.3 & 12 \\
\hline 30 & April & 1991 & 0 & 0 \\
\hline
\end{tabular}




\begin{tabular}{|c|c|c|c|c|}
\hline Day & Month & Year & $\begin{array}{c}\text { Total Precip } \\
\text { (inches) }\end{array}$ & $\begin{array}{c}\text { Total Snow } \\
\text { (inches) }\end{array}$ \\
\hline 31 & May & 1991 & 1.77 & 0 \\
\hline 30 & June & 1991 & 1.71 & 0 \\
\hline 31 & July & 1991 & 5.03 & 0 \\
\hline 31 & August & 1991 & 5.93 & 0 \\
\hline 30 & September & 1991 & 2.73 & 0 \\
\hline 31 & October & 1991 & 0.35 & 7.3 \\
\hline 30 & November & 1991 & 2.56 & 12.1 \\
\hline 31 & December & 1991 & 2.23 & 18.1 \\
\hline 31 & January & 1992 & 0.61 & 5.1 \\
\hline 29 & February & 1992 & 0.34 & 1 \\
\hline 31 & March & 1992 & 1.21 & 1.5 \\
\hline 30 & April & 1992 & 0.59 & 0 \\
\hline 31 & May & 1992 & 3.46 & 0 \\
\hline 30 & June & 1992 & 1.29 & 0 \\
\hline 31 & July & 1992 & 1.41 & 0 \\
\hline 31 & August & 1992 & 5.05 & 0 \\
\hline 30 & September & 1992 & 2.26 & 0 \\
\hline 31 & October & 1992 & 0.59 & 0 \\
\hline 30 & November & 1992 & 1.28 & 5.6 \\
\hline 31 & December & 1992 & 1.69 & 21.3 \\
\hline 31 & January & 1993 & 3.22 & 33 \\
\hline 28 & February & 1993 & 2.12 & 13.5 \\
\hline 31 & March & 1993 & 1.2 & 5 \\
\hline 30 & April & 1993 & 0.05 & 0 \\
\hline 31 & May & 1993 & 1.15 & 0 \\
\hline 30 & June & 1993 & 0.7 & 0 \\
\hline 31 & July & 1993 & 3.37 & 0 \\
\hline 31 & August & 1993 & 5.43 & 0 \\
\hline 30 & September & 1993 & 1.12 & 0 \\
\hline 31 & October & 1993 & 0.59 & 3 \\
\hline 30 & November & 1993 & 1.44 & 4 \\
\hline 31 & December & 1993 & 0.21 & 3 \\
\hline 31 & January & 1994 & 0.44 & 8 \\
\hline 28 & February & 1994 & 0.69 & 5.9 \\
\hline 31 & March & 1994 & 2.05 & 18.8 \\
\hline 30 & April & 1994 & 1.66 & 9.3 \\
\hline 31 & May & 1994 & 2.54 & 0 \\
\hline 30 & June & 1994 & 1.13 & 0 \\
\hline 31 & July & 1994 & 2.21 & 0 \\
\hline 31 & August & 1994 & 2.58 & 0 \\
\hline 30 & September & 1994 & 0.83 & 0 \\
\hline
\end{tabular}

\begin{tabular}{|c|c|c|c|c|}
\hline Day & Month & Year & $\begin{array}{c}\text { Total Precip } \\
\text { (inches) }\end{array}$ & $\begin{array}{c}\text { Total Snow } \\
\text { (inches) }\end{array}$ \\
\hline 31 & October & 1994 & 3.17 & 0 \\
\hline 30 & November & 1994 & 2.07 & 0 \\
\hline 31 & December & 1994 & 0.71 & 2.5 \\
\hline 31 & January & 1995 & 1.34 & 21.3 \\
\hline 28 & February & 1995 & 1.01 & 3.3 \\
\hline 31 & March & 1995 & 1.11 & 9.7 \\
\hline 30 & April & 1995 & 1.82 & 20.4 \\
\hline 31 & May & 1995 & 2.68 & 2.8 \\
\hline 30 & June & 1995 & 1.83 & 0 \\
\hline 31 & July & 1995 & 1.28 & 0 \\
\hline 31 & August & 1995 & 3.53 & 0 \\
\hline 30 & September & 1995 & 2.36 & 0 \\
\hline 31 & October & 1995 & 0 & 0 \\
\hline 30 & November & 1995 & 0.35 & 1.7 \\
\hline 31 & December & 1995 & 0.61 & 12.4 \\
\hline 31 & January & 1996 & 1.29 & 14.1 \\
\hline 29 & February & 1996 & 0.69 & 10.4 \\
\hline 31 & March & 1996 & 0.39 & 4.8 \\
\hline 30 & April & 1996 & 0.11 & 0 \\
\hline 31 & May & 1996 & 0.02 & 0 \\
\hline 30 & June & 1996 & 3.83 & 0 \\
\hline 31 & July & 1996 & 2.96 & 0 \\
\hline 31 & August & 1996 & 2.25 & 0 \\
\hline 30 & September & 1996 & 2.2 & 0 \\
\hline 31 & October & 1996 & 3.37 & 21.2 \\
\hline 30 & November & 1996 & 0.64 & 5.9 \\
\hline 31 & December & 1996 & 0.09 & 1.2 \\
\hline 31 & January & 1997 & 1.68 & 20.8 \\
\hline 28 & February & 1997 & 2.18 & 23.1 \\
\hline 31 & March & 1997 & 0.09 & 0 \\
\hline 30 & April & 1997 & 2.04 & 9.6 \\
\hline 31 & May & 1997 & 1.55 & 0 \\
\hline 30 & June & 1997 & 1.91 & 0 \\
\hline 31 & July & 1997 & 2.63 & 0 \\
\hline 31 & August & 1997 & 6.44 & 0 \\
\hline 30 & September & 1997 & 3.4 & 0 \\
\hline 31 & October & 1997 & 0.59 & 0 \\
\hline 30 & November & 1997 & 1.16 & 16 \\
\hline 31 & December & 1997 & 1.83 & 26.4 \\
\hline 31 & January & 1998 & 0.12 & 0 \\
\hline 28 & February & 1998 & 0.39 & 6.7 \\
\hline
\end{tabular}




\begin{tabular}{|c|c|c|c|c|}
\hline Day & Month & Year & $\begin{array}{c}\text { Total Precip } \\
\text { (inches) }\end{array}$ & $\begin{array}{c}\text { Total Snow } \\
\text { (inches) }\end{array}$ \\
\hline 31 & March & 1998 & 1.59 & 3.7 \\
\hline 30 & April & 1998 & 0.61 & 0.5 \\
\hline 31 & May & 1998 & 0 & 0 \\
\hline 30 & June & 1998 & 0.44 & 0 \\
\hline 31 & July & 1998 & 5.29 & 0 \\
\hline 31 & August & 1998 & 3.32 & 0 \\
\hline 30 & September & 1998 & 0.8 & 0 \\
\hline 31 & October & 1998 & 4.16 & 0 \\
\hline 30 & November & 1998 & 0.52 & 0 \\
\hline 31 & December & 1998 & 0.06 & 0.6 \\
\hline 31 & January & 1999 & 0.15 & 1.2 \\
\hline 28 & February & 1999 & 0.07 & 0.2 \\
\hline 31 & March & 1999 & 1.44 & 15.2 \\
\hline 30 & April & 1999 & 2.41 & 5.7 \\
\hline 31 & May & 1999 & 1.81 & 0 \\
\hline 30 & June & 1999 & 1.72 & 0 \\
\hline 31 & July & 1999 & 3.01 & 0 \\
\hline 31 & August & 1999 & 2.06 & 0 \\
\hline 30 & September & 1999 & 2.71 & 0 \\
\hline 31 & October & 1999 & 0.57 & 1.8 \\
\hline 30 & November & 1999 & 0.02 & 0 \\
\hline 31 & December & 1999 & 0.34 & 4.7 \\
\hline 31 & January & 2000 & 0.24 & 1.2 \\
\hline 29 & February & 2000 & 0.07 & 1.2 \\
\hline 31 & March & 2000 & 1.32 & 5.8 \\
\hline 30 & April & 2000 & 0.39 & 1 \\
\hline 31 & May & 2000 & 0.15 & 0 \\
\hline 30 & June & 2000 & 1.47 & 0 \\
\hline 31 & July & 2000 & 1.63 & 0 \\
\hline 31 & August & 2000 & 1.77 & 0 \\
\hline 30 & September & 2000 & 0.34 & 0 \\
\hline 31 & October & 2000 & 4.1 & 0 \\
\hline 30 & November & 2000 & 1.95 & 13.8 \\
\hline 31 & December & 2000 & 0.37 & 4.9 \\
\hline 31 & January & 2001 & 2.35 & 35.2 \\
\hline 28 & February & 2001 & 0.93 & 7.2 \\
\hline 31 & March & 2001 & 1.14 & 5.8 \\
\hline 30 & April & 2001 & 0.94 & 0 \\
\hline 31 & May & 2001 & 1.43 & 0 \\
\hline 30 & June & 2001 & 0.85 & 0 \\
\hline 31 & July & 2001 & 2.45 & 0 \\
\hline
\end{tabular}

\begin{tabular}{|c|c|c|c|c|}
\hline Day & Month & Year & $\begin{array}{c}\text { Total Precip } \\
\text { (inches) }\end{array}$ & $\begin{array}{l}\text { Total Snow } \\
\text { (inches) }\end{array}$ \\
\hline 31 & August & 2001 & 3.16 & 0 \\
\hline 30 & September & 2001 & 0.39 & 0 \\
\hline 31 & October & 2001 & 0.1 & 0 \\
\hline 30 & November & 2001 & 0.5 & 4.5 \\
\hline 31 & December & 2001 & 0.18 & 2.3 \\
\hline 31 & January & 2002 & 0.73 & 8.4 \\
\hline 28 & February & 2002 & 0.03 & 0 \\
\hline 31 & March & 2002 & 0.03 & 0 \\
\hline 30 & April & 2002 & 0.21 & 0 \\
\hline 31 & May & 2002 & 0 & 0 \\
\hline 30 & June & 2002 & 1.91 & 0 \\
\hline 31 & July & 2002 & 1.71 & 0 \\
\hline 31 & August & 2002 & 1.14 & 0 \\
\hline 30 & September & 2002 & 2.12 & 0 \\
\hline 31 & October & 2002 & 1.64 & 0 \\
\hline 30 & November & 2002 & 1.36 & 6.6 \\
\hline 31 & December & 2002 & 0.83 & 10.4 \\
\hline 31 & January & 2003 & 0 & 0 \\
\hline 28 & February & 2003 & 0.88 & 7.3 \\
\hline 31 & March & 2003 & 0.63 & 3.2 \\
\hline 30 & April & 2003 & 0.49 & 0 \\
\hline 31 & May & 2003 & 1.35 & 0 \\
\hline 30 & June & 2003 & 0.71 & 0 \\
\hline 31 & July & 2003 & 0.26 & 0 \\
\hline 31 & August & 2003 & 2.78 & 0 \\
\hline 30 & September & 2003 & 0.84 & 0 \\
\hline 31 & October & 2003 & 0.9 & 0 \\
\hline 30 & November & 2003 & 0.78 & 3.4 \\
\hline 31 & December & 2003 & 0.31 & 1.4 \\
\hline 31 & January & 2004 & 0.41 & 8.5 \\
\hline 29 & February & 2004 & 2.22 & 37.8 \\
\hline 31 & March & 2004 & 0.85 & 9.4 \\
\hline 30 & April & 2004 & 3.08 & 4.4 \\
\hline 31 & May & 2004 & 0.02 & 0 \\
\hline 30. & June & 2004 & 0.75 & 0 \\
\hline 31 & July & 2004 & 3.13 & 0 \\
\hline 31 & August & 2004 & 1.83 & 0 \\
\hline 30 & September & 2004 & 1.63 & 0 \\
\hline 31 & October & 2004 & 2.5 & 0 \\
\hline 30 & November & 2004 & 1.47 & 14.6 \\
\hline 31 & December & 2004 & 0.89 & 7.7 \\
\hline
\end{tabular}




\begin{tabular}{|c|c|c|c|c|}
\hline Day & Month & Year & $\begin{array}{c}\text { Total Precip } \\
\text { (inches) }\end{array}$ & $\begin{array}{c}\text { Total Snow } \\
\text { (inches) }\end{array}$ \\
\hline 31 & January & 2005 & 2.63 & 13.1 \\
\hline 28 & February & 2005 & 2.11 & 12.7 \\
\hline 31 & March & 2005 & 1.91 & 22.2 \\
\hline 30 & April & 2005 & 1.45 & 0 \\
\hline 31 & May & 2005 & 0.92 & 0 \\
\hline 30 & June & 2005 & 0.26 & 0 \\
\hline 31 & July & 2005 & 1.63 & 0 \\
\hline 31 & August & 2005 & 5.76 & 0 \\
\hline 30 & September & 2005 & 3.44 & 0 \\
\hline 31 & October & 2005 & 1.11 & 0 \\
\hline 30 & November & 2005 & 0.07 & 0 \\
\hline 31 & December & 2005 & 0.01 & 0.3 \\
\hline 31 & January & 2006 & 0.15 & 0 \\
\hline 28 & February & 2006 & 0.02 & 0 \\
\hline 31 & March & 2006 & 0.63 & 5.3 \\
\hline 30 & April & 2006 & 0.51 & 0 \\
\hline 31 & May & 2006 & 0.22 & 0 \\
\hline 30 & June & 2006 & 1.78 & 0 \\
\hline 31 & July & 2006 & 2.26 & 0 \\
\hline 31 & August & 2006 & 5.85 & 0 \\
\hline 30 & September & 2006 & 1.36 & 0 \\
\hline 31 & October & 2006 & 1.73 & 0 \\
\hline 30 & November & 2006 & 0.49 & 6.9 \\
\hline 31 & December & 2006 & 1.62 & 25.1 \\
\hline 31 & January & 2007 & 1.06 & 13.9 \\
\hline 28 & February & 2007 & 0.54 & 6.2 \\
\hline 31 & March & 2007 & 1.23 & 0 \\
\hline 30 & April & 2007 & 0.62 & 0 \\
\hline 31 & May & 2007 & 1.7 & 0 \\
\hline 30 & June & 2007 & 1.28 & 0 \\
\hline 31 & July & 2007 & 1.93 & 0 \\
\hline 31 & August & 2007 & 2.93 & 0 \\
\hline 30 & September & 2007 & 4.35 & 0 \\
\hline 31 & October & 2007 & 0.32 & 0 \\
\hline 30 & November & 2007 & 1.61 & 5.6 \\
\hline 31 & December & 2007 & 2.74 & 9.5 \\
\hline 31 & January & 2008 & 1.39 & 7.6 \\
\hline 29 & February & 2008 & 1.11 & 13.5 \\
\hline 31 & March & 2008 & 0.46 & 9.5 \\
\hline 30 & April & 2008 & 0.13 & 0.8 \\
\hline 31 & May & 2008 & 1.66 & 0 \\
\hline
\end{tabular}

\begin{tabular}{|c|c|c|c|c|}
\hline Day & Month & Year & $\begin{array}{c}\text { Total Precip } \\
\text { (inches) }\end{array}$ & $\begin{array}{l}\text { Total Snow } \\
\text { (inches) }\end{array}$ \\
\hline 30 & June & 2008 & 0.04 & 0 \\
\hline 31 & July & 2008 & 2.59 & 0 \\
\hline 31 & August & 2008 & 6.01 & 0 \\
\hline 30 & September & 2008 & 0.33 & 0 \\
\hline 31 & October & 2008 & 1.43 & 0 \\
\hline 30 & November & 2008 & 0.6 & 1 \\
\hline 31 & December & 2008 & 1.63 & 29 \\
\hline 31 & January & 2009 & 0.26 & 4.8 \\
\hline 28 & February & 2009 & 0.02 & 0.2 \\
\hline 31 & March & 2009 & 1.18 & 8.7 \\
\hline 30 & April & 2009 & 1.31 & 9.8 \\
\hline 31 & May & 2009 & 2.14 & 0 \\
\hline 30 & June & 2009 & 2.67 & 0 \\
\hline 31 & July & 2009 & 4.01 & 0 \\
\hline 31 & August & 2009 & 1.66 & 0 \\
\hline 30 & September & 2009 & 1.95 & 0 \\
\hline 31 & October & 2009 & 1.87 & 1.6 \\
\hline 30 & November & 2009 & 0.26 & 1.6 \\
\hline 31 & December & 2009 & 1.27 & 16.7 \\
\hline 31 & January & 2010 & 1.32 & 13.5 \\
\hline 28 & February & 2010 & 1.23 & 18.2 \\
\hline 31 & March & 2010 & 1 & 11.4 \\
\hline 30 & April & 2010 & 1.43 & 0 \\
\hline 31 & May & 2010 & 1.1 & 0 \\
\hline 30 & June & 2010 & 0.59 & 0 \\
\hline 31 & July & 2010 & 4.1 & 0 \\
\hline 31 & August & 2010 & 3.43 & 0 \\
\hline 30 & September & 2010 & 1.32 & 0 \\
\hline 31 & October & 2010 & 2.09 & 0 \\
\hline 30 & November & 2010 & 0.03 & 0 \\
\hline 31 & December & 2010 & 1.18 & 16.6 \\
\hline 31 & January & 2011 & 0.01 & 0 \\
\hline 28 & February & 2011 & 0.04 & 1.4 \\
\hline 31 & March & 2011 & 0.16 & 0.6 \\
\hline 30 & April & 2011 & 0.47 & 0 \\
\hline 31 & May & 2011 & 0.18 & 0.7 \\
\hline 30 & June & 2011 & 0 & 0 \\
\hline 31 & July & 2011 & 0.77 & 0 \\
\hline 31 & August & 2011 & 4.98 & 0 \\
\hline 30 & September & 2011 & 3.04 & 0 \\
\hline 31 & October & 2011 & 1.62 & 0 \\
\hline
\end{tabular}




\begin{tabular}{|c|c|c|c|c|}
\hline Day & Month & Year & \begin{tabular}{|c|}
$\begin{array}{c}\text { Total Precip } \\
\text { (inches) }\end{array}$ \\
\end{tabular} & $\begin{array}{c}\text { Total Snow } \\
\text { (inches) }\end{array}$ \\
\hline 30 & November & 2011 & 0.36 & 0 \\
\hline 31 & December & 2011 & 2.02 & 31.4 \\
\hline 31 & January & 2012 & 0.22 & 2.4 \\
\hline 29 & February & 2012 & 0.53 & 9.7 \\
\hline 31 & March & 2012 & 0.3 & 4.4 \\
\hline 30 & April & 2012 & 0.9 & 8.5 \\
\hline 31 & May & 2012 & 0.93 & 0 \\
\hline 30 & June & 2012 & 0.05 & 0 \\
\hline 31 & July & 2012 & 1.51 & 0 \\
\hline 31 & August & 2012 & 1.52 & 0 \\
\hline 30 & September & 2012 & 1.69 & 0 \\
\hline 31 & October & 2012 & 1.02 & 0 \\
\hline 30 & November & 2012 & 0.12 & 0 \\
\hline 31 & December & 2012 & 0.8 & 12.2 \\
\hline 31 & January & 2013 & 0.52 & 1.9 \\
\hline 28 & February & 2013 & 0.45 & 5 \\
\hline 31 & March & 2013 & 0.15 & 0.5 \\
\hline 30 & April & 2013 & 0.6 & 3 \\
\hline 31 & May & 2013 & 0.11 & 0 \\
\hline 30 & June & 2013 & 0.76 & 0 \\
\hline 31 & July & 2013 & 3.71 & 0 \\
\hline 31 & August & 2013 & 1.8 & 0 \\
\hline 30 & September & 2013 & 8.72 & 0 \\
\hline 31 & October & 2013 & 1.44 & 2 \\
\hline 30 & November & 2013 & 2.03 & 8.5 \\
\hline 31 & December & 2013 & 0.15 & 4.2 \\
\hline 31 & January & 2014 & 0.02 & 0.5 \\
\hline 28 & February & 2014 & 0.2 & 0.5 \\
\hline 31 & March & 2014 & 1.08 & 1.1 \\
\hline 30 & April & 2014 & 0.3 & 0 \\
\hline 31 & May & 2014 & 1.48 & 0 \\
\hline 30 & June & 2014 & 0.91 & 0 \\
\hline 31 & July & 2014 & 9.04 & 0 \\
\hline 31 & August & 2014 & 1.28 & 0 \\
\hline 30 & September & 2014 & 0.3 & 0 \\
\hline 31 & October & 2014 & 0.85 & 0 \\
\hline 30 & November & 2014 & 0.51 & 1 \\
\hline 31 & December & 2014 & 0.85 & 3.3 \\
\hline 31 & January & 2015 & 1.28 & 14.8 \\
\hline 28 & February & 2015 & 0.84 & 15.9 \\
\hline 31 & March & 2015 & 0.84 & 1.7 \\
\hline
\end{tabular}

\begin{tabular}{|r|l|r|r|r|}
\hline Day & Month & Year & $\begin{array}{c}\text { Total Precip } \\
\text { (inches) }\end{array}$ & $\begin{array}{c}\text { Total Snow } \\
\text { (inches) }\end{array}$ \\
\hline 30 & April & 2015 & 0.85 & 3.6 \\
\hline 31 & May & 2015 & 2.8 & 0 \\
\hline 30 & June & 2015 & 2.12 & 0 \\
\hline 31 & July & 2015 & 6.68 & 0 \\
\hline 31 & August & 2015 & 2.66 & 0 \\
\hline 30 & September & 2015 & 0.35 & 0 \\
\hline 31 & October & 2015 & 3.15 & 0 \\
\hline 30 & November & 2015 & 0.8 & 2 \\
\hline 31 & December & 2015 & 0.88 & 14.7 \\
\hline
\end{tabular}




\section{White Rock Temperatures}

Data is for tower wrarc. This file was obtained from the LANL Weather Machine http://weather.lanl.gov. Request made on Tuesday, July 19 09:22:13 2016 MST.

\begin{tabular}{|l|r|r|r|}
\hline \multicolumn{1}{|c|}{ Month } & Year & $\begin{array}{c}\text { Average } \\
\text { Max Temp } \\
\text { ('F) }\end{array}$ & $\begin{array}{c}\text { Average Min } \\
\left.\text { Temp ( }{ }^{\circ} \mathbf{F}\right)\end{array}$ \\
\hline October & 1964 & 68.7 & 35.7 \\
\hline November & 1964 & 52.0 & 23.9 \\
\hline December & 1964 & 43.0 & 16.6 \\
\hline January & 1965 & 41.9 & 18.2 \\
\hline February & 1965 & 44.5 & 15.0 \\
\hline March & 1965 & 48.9 & 23.4 \\
\hline April & 1965 & 63.0 & 32.3 \\
\hline May & 1965 & 69.4 & 39.9 \\
\hline June & 1965 & 78.3 & 48.1 \\
\hline July & 1965 & 85.5 & 56.8 \\
\hline August & 1965 & 81.5 & 52.0 \\
\hline September & 1965 & 71.5 & 44.4 \\
\hline October & 1965 & 69.2 & 32.1 \\
\hline November & 1965 & 57.3 & 26.6 \\
\hline December & 1965 & 44.1 & 16.8 \\
\hline January & 1966 & 38.1 & 9.5 \\
\hline February & 1966 & 40.9 & 14.0 \\
\hline March & 1966 & 59.0 & 23.7 \\
\hline April & 1966 & 66.0 & 32.9 \\
\hline May & 1966 & 78.4 & 43.5 \\
\hline June & 1966 & 80.9 & 49.9 \\
\hline July & 1966 & 88.5 & 55.5 \\
\hline August & 1966 & 80.5 & 51.0 \\
\hline September & 1966 & 76.0 & 42.8 \\
\hline October & 1966 & 68.4 & 31.6 \\
\hline November & 1966 & 58.0 & 23.3 \\
\hline December & 1966 & 43.7 & 11.5 \\
\hline January & 1967 & 45.9 & 9.2 \\
\hline February & 1967 & 52.1 & 18.9 \\
\hline March & 1967 & 63.0 & 28.7 \\
\hline April & 1967 & 62.8 & 30.9 \\
\hline May & 1967 & 71.1 & 36.8 \\
\hline June & 1967 & 77.7 & 47.4 \\
\hline July & 1967 & 86.1 & 57.0 \\
\hline August & 1967 & 80.8 & 52.4 \\
\hline September & 1967 & 75.6 & 46.4 \\
\hline October & 1967 & 69.9 & 33.7 \\
\hline November & 1967 & 57.9 & 25.0 \\
\hline December & 1967 & 37.3 & 10.8 \\
\hline January & 1968 & 43.3 & 12.3 \\
\hline February & 1968 & 49.9 & 22.3 \\
\hline March & 1968 & 54.0 & 25.6 \\
\hline April & 1968 & 57.5 & 27.8 \\
\hline
\end{tabular}

\begin{tabular}{|l|r|r|r|}
\hline \multicolumn{1}{|c|}{ Month } & Year & $\begin{array}{c}\text { Average } \\
\text { Max Temp } \\
\text { ('F) }\end{array}$ & $\begin{array}{c}\text { Average Min } \\
\text { Temp ('F) }\end{array}$ \\
\hline May & 1968 & 69.8 & 38.4 \\
\hline June & 1968 & 84.2 & 48.7 \\
\hline July & 1968 & 82.8 & 54.1 \\
\hline August & 1968 & 77.7 & 51.8 \\
\hline September & 1968 & 76.6 & 42.8 \\
\hline October & 1968 & 68.3 & 32.4 \\
\hline November & 1968 & 51.8 & 22.4 \\
\hline December & 1968 & 41.9 & 9.0 \\
\hline January & 1969 & 48.4 & 21.6 \\
\hline February & 1969 & 48.0 & 19.3 \\
\hline March & 1969 & 49.9 & 20.1 \\
\hline April & 1969 & 65.1 & 35.2 \\
\hline May & 1969 & 74.4 & 42.5 \\
\hline June & 1969 & 79.6 & 48.6 \\
\hline July & 1969 & 86.6 & 57.7 \\
\hline August & 1969 & 86.3 & 56.7 \\
\hline September & 1969 & 77.3 & 47.1 \\
\hline October & 1969 & 61.4 & 35.3 \\
\hline November & 1969 & 53.6 & 22.9 \\
\hline December & 1969 & 46.6 & 21.0 \\
\hline January & 1970 & 44.2 & 13.5 \\
\hline February & 1970 & 52.5 & 22.6 \\
\hline March & 1970 & 50.1 & 24.0 \\
\hline April & 1970 & 60.3 & 28.5 \\
\hline May & 1970 & 75.3 & 42.8 \\
\hline June & 1970 & 79.8 & 48.5 \\
\hline July & 1970 & 85.5 & 56.4 \\
\hline August & 1970 & 84.0 & 56.3 \\
\hline September & 1970 & 74.3 & 46.1 \\
\hline October & 1970 & 59.6 & 32.4 \\
\hline November & 1970 & 53.6 & 25.1 \\
\hline December & 1970 & 46.5 & 16.8 \\
\hline January & 1971 & 43.0 & 12.9 \\
\hline February & 1971 & 46.3 & 19.3 \\
\hline March & 1971 & 57.7 & 24.2 \\
\hline April & 1971 & 62.4 & 32.1 \\
\hline May & 1971 & 72.1 & 38.5 \\
\hline June & 1971 & 83.9 & 50.9 \\
\hline July & 1971 & 85.6 & 56.6 \\
\hline August & 1971 & 81.8 & 53.4 \\
\hline September & 1971 & 73.4 & 45.1 \\
\hline October & 1971 & 62.5 & 34.6 \\
\hline November & 1971 & 51.4 & 25.0 \\
\hline
\end{tabular}




\begin{tabular}{|c|c|c|c|}
\hline Month & Year & $\begin{array}{c}\text { Average } \\
\text { Max Temp } \\
\left({ }^{\circ} \mathrm{F}\right)\end{array}$ & $\begin{array}{c}\text { Average Min } \\
\text { Temp }\left({ }^{\circ} \mathrm{F}\right)\end{array}$ \\
\hline December & 1971 & 38.6 & 14.5 \\
\hline January & 1972 & 43.2 & 15.2 \\
\hline February & 1972 & 51.8 & 21.4 \\
\hline March & 1972 & 63.5 & 30.9 \\
\hline April & 1972 & 67.4 & 34.1 \\
\hline May & 1972 & 73.1 & 40.9 \\
\hline June & 1972 & 81.9 & 51.1 \\
\hline July & 1972 & 83.9 & 55.5 \\
\hline August & 1972 & 80.8 & 54.3 \\
\hline September & 1972 & 74.1 & 47.9 \\
\hline October & 1972 & 61.7 & 40.1 \\
\hline November & 1972 & 44.1 & 20.9 \\
\hline December & 1972 & 40.5 & 15.7 \\
\hline January & 1973 & 38.7 & 14.1 \\
\hline February & 1973 & 43.3 & 19.7 \\
\hline March & 1973 & 48.5 & 26.1 \\
\hline April & 1973 & 56.3 & 28.1 \\
\hline May & 1973 & 70.1 & 40.8 \\
\hline June & 1973 & 81.8 & 49.2 \\
\hline July & 1973 & 84.6 & 55.3 \\
\hline August & 1973 & 84.7 & 53.9 \\
\hline September & 1973 & 77.0 & 45.4 \\
\hline October & 1973 & 68.0 & 36.1 \\
\hline November & 1973 & 56.1 & 26.6 \\
\hline December & 1973 & 45.6 & 17.4 \\
\hline January & 1974 & 37.7 & 13.6 \\
\hline February & 1974 & 44.5 & 14.9 \\
\hline March & 1974 & 60.0 & 29.6 \\
\hline April & 1974 & 62.4 & 31.0 \\
\hline May & 1974 & 76.9 & 43.1 \\
\hline June & 1974 & 86.4 & 52.0 \\
\hline July & 1974 & 84.4 & 54.5 \\
\hline August & 1974 & 79.7 & 51.8 \\
\hline September & 1974 & 73.6 & 45.2 \\
\hline October & 1974 & 62.4 & 38.7 \\
\hline November & 1974 & 50.7 & 23.4 \\
\hline December & 1974 & 36.7 & 10.1 \\
\hline January & 1975 & 36.4 & 8.6 \\
\hline February & 1975 & 41.8 & 17.0 \\
\hline March & 1975 & 50.1 & 25.8 \\
\hline April & 1975 & 56.6 & 29.0 \\
\hline May & 1975 & 70.2 & 37.7 \\
\hline June & 1975 & 82.7 & 48.5 \\
\hline July & 1975 & 84.3 & 55.7 \\
\hline August & 1975 & 85.3 & 54.4 \\
\hline September & 1975 & 73.6 & 45.5 \\
\hline October & 1975 & 68.1 & 32.9 \\
\hline November & 1975 & 51.7 & 20.2 \\
\hline
\end{tabular}

\begin{tabular}{|l|r|r|r|}
\hline \multicolumn{1}{|c|}{ Month } & Year & $\begin{array}{c}\text { Average } \\
\text { Max Temp } \\
\text { ('F) }\end{array}$ & $\begin{array}{c}\text { Average Min } \\
\left.\text { Temp ( }{ }^{\circ} \mathbf{F}\right)\end{array}$ \\
\hline December & 1975 & 44.8 & 15.7 \\
\hline January & 1976 & 43.7 & 12.0 \\
\hline February & 1976 & 52.3 & 22.8 \\
\hline March & 1976 & 54.1 & 24.8 \\
\hline April & 1976 & 63.3 & 33.7 \\
\hline May & 1976 & 72.8 & 42.5 \\
\hline June & 1976 & 84.0 & 50.2 \\
\hline July & 1976 & 84.0 & 53.8 \\
\hline August & 1976 & 79.8 & 51.1 \\
\hline September & 1976 & 72.7 & 45.3 \\
\hline October & 1976 & 59.8 & 29.2 \\
\hline November & 1976 & 51.5 & 17.7 \\
\hline December & 1976 & 40.5 & 7.9 \\
\hline January & 1977 & 36.8 & 8.6 \\
\hline February & 1977 & 48.0 & 19.2 \\
\hline March & 1977 & 51.2 & 23.0 \\
\hline April & 1977 & 63.3 & 34.7 \\
\hline May & 1977 & 72.4 & 41.3 \\
\hline June & 1977 & 86.7 & 52.4 \\
\hline July & 1977 & 86.5 & 57.2 \\
\hline August & 1977 & 84.9 & 57.1 \\
\hline September & 1977 & 78.1 & 48.5 \\
\hline October & 1977 & 69.7 & 36.2 \\
\hline November & 1977 & 52.4 & 23.0 \\
\hline December & 1977 & 46.7 & 19.0 \\
\hline January & 1978 & 39.9 & 18.0 \\
\hline February & 1978 & 44.0 & 19.0 \\
\hline March & 1978 & 55.9 & 26.5 \\
\hline April & 1978 & 64.3 & 33.1 \\
\hline May & 1978 & 67.0 & 37.2 \\
\hline June & 1978 & 83.5 & 52.1 \\
\hline July & 1978 & 87.7 & 55.2 \\
\hline August & 1978 & 82.4 & 50.6 \\
\hline September & 1978 & 75.4 & 45.1 \\
\hline October & 1978 & 66.0 & 36.0 \\
\hline November & 1978 & 48.3 & 28.8 \\
\hline December & 1978 & 37.0 & 13.4 \\
\hline January & 1979 & 34.4 & 11.7 \\
\hline February & 1979 & 45.2 & 18.7 \\
\hline March & 1979 & 53.9 & 27.8 \\
\hline April & 1979 & 62.8 & 34.7 \\
\hline May & 1979 & 67.4 & 40.1 \\
\hline June & 1979 & 79.1 & 47.3 \\
\hline Sugty & 1979 & 79.2 & 53.9 \\
\hline November & & & \\
\hline
\end{tabular}




\begin{tabular}{|l|r|r|r|}
\hline \multicolumn{1}{|c|}{ Month } & Year & $\begin{array}{c}\text { Average } \\
\text { Max Temp } \\
\text { ('F) }\end{array}$ & $\begin{array}{c}\text { Average Min } \\
\left.\text { Temp ( }{ }^{\circ} \mathbf{F}\right)\end{array}$ \\
\hline December & & & \\
\hline January & & & \\
\hline February & & & \\
\hline March & & & \\
\hline April & & & \\
\hline May & 1980 & 67.5 & 38.3 \\
\hline June & 1980 & 88.1 & 52.0 \\
\hline July & 1980 & 90.3 & 57.1 \\
\hline August & 1980 & 83.6 & 53.7 \\
\hline September & 1980 & 78.1 & 47.3 \\
\hline October & 1980 & 66.0 & 33.6 \\
\hline November & 1980 & 53.3 & 22.7 \\
\hline December & 1980 & 51.1 & 22.3 \\
\hline January & 1981 & 46.5 & 17.4 \\
\hline February & 1981 & 41.2 & 9.1 \\
\hline March & 1981 & & \\
\hline April & 1981 & 67.9 & 36.9 \\
\hline May & 1981 & 70.5 & 43.1 \\
\hline June & 1981 & 86.8 & 54.2 \\
\hline July & 1981 & 87.2 & 57.7 \\
\hline August & 1981 & 83.2 & 55.6 \\
\hline September & 1981 & 76.1 & 48.8 \\
\hline October & 1981 & 63.3 & 38.1 \\
\hline November & 1981 & 57.2 & 27.7 \\
\hline December & 1981 & 48.5 & 21.1 \\
\hline January & 1982 & 40.7 & 16.5 \\
\hline February & 1982 & 44.0 & 16.4 \\
\hline March & 1982 & 53.6 & 28.2 \\
\hline April & 1982 & 62.8 & 34.7 \\
\hline May & 1982 & 70.0 & 40.3 \\
\hline June & 1982 & 82.3 & 51.9 \\
\hline July & 1982 & 86.7 & 57.3 \\
\hline August & 1982 & 83.9 & 56.7 \\
\hline September & 1982 & 74.7 & 49.7 \\
\hline October & 1982 & 63.5 & 33.4 \\
\hline November & 1982 & 47.9 & 26.0 \\
\hline December & 1982 & 39.2 & 17.7 \\
\hline January & 1983 & 42.6 & 18.0 \\
\hline February & 1983 & 46.9 & 22.4 \\
\hline March & 1983 & 52.7 & 29.4 \\
\hline April & 1983 & 56.9 & 29.4 \\
\hline May & 1983 & 68.8 & \\
\hline June & 1983 & 80.3 & \\
\hline July & 1983 & & \\
\hline August & 1983 & 51.7 & \\
\hline September & 1983 & & \\
\hline October & & & \\
\hline November & & & \\
\hline
\end{tabular}

\begin{tabular}{|l|r|r|r|}
\hline \multicolumn{1}{|c|}{ Month } & Year & $\begin{array}{c}\text { Average } \\
\text { Max Temp } \\
\text { ('F) }\end{array}$ & $\begin{array}{c}\text { Average Min } \\
\left.\text { Temp ( }{ }^{\circ} \mathbf{F}\right)\end{array}$ \\
\hline December & 1983 & 41.2 & 18.5 \\
\hline January & 1984 & 40.9 & 11.1 \\
\hline February & 1984 & 48.9 & 17.4 \\
\hline March & 1984 & 53.4 & 25.2 \\
\hline April & 1984 & 60.5 & 31.4 \\
\hline May & 1984 & 78.6 & 46.0 \\
\hline June & 1984 & 82.1 & 49.5 \\
\hline July & 1984 & 86.1 & 54.9 \\
\hline August & 1984 & 82.4 & 54.4 \\
\hline September & 1984 & 76.7 & 48.0 \\
\hline October & 1984 & 55.5 & 32.7 \\
\hline November & 1984 & 51.1 & 25.0 \\
\hline December & 1984 & 41.0 & 19.5 \\
\hline January & 1985 & 38.3 & 17.8 \\
\hline February & 1985 & 44.3 & 18.2 \\
\hline March & 1985 & 53.3 & 29.0 \\
\hline April & 1985 & 64.8 & 34.4 \\
\hline May & 1985 & 71.7 & 42.8 \\
\hline June & 1985 & 82.5 & 50.6 \\
\hline July & 1985 & 85.3 & 55.3 \\
\hline August & 1985 & 84.0 & 54.0 \\
\hline September & 1985 & 74.1 & 44.9 \\
\hline October & 1985 & 66.0 & 38.7 \\
\hline November & 1985 & 54.1 & 30.4 \\
\hline December & 1985 & 48.4 & 19.9 \\
\hline January & 1986 & 54.0 & 23.4 \\
\hline February & 1986 & 52.2 & 27.5 \\
\hline March & 1986 & 59.0 & 28.9 \\
\hline April & 1986 & 65.2 & 37.6 \\
\hline May & 1986 & 72.2 & 43.3 \\
\hline June & 1986 & 79.7 & 50.8 \\
\hline July & 1986 & 83.8 & 55.1 \\
\hline August & 1986 & 85.4 & 55.5 \\
\hline September & 1986 & 73.7 & 44.9 \\
\hline October & 1986 & 62.0 & 33.7 \\
\hline November & 1986 & 49.2 & 25.6 \\
\hline December & 1986 & 42.9 & 19.9 \\
\hline January & 1987 & 41.8 & 15.3 \\
\hline February & 1987 & 46.2 & 22.6 \\
\hline March & 1987 & 52.1 & 24.7 \\
\hline April & 1987 & 64.8 & 32.7 \\
\hline May & 1987 & 69.0 & 40.9 \\
\hline June & 1987 & 83.3 & 51.4 \\
\hline Sugust & 1987 & 80.5 & 53.8 \\
\hline November & 1987 & 76.4 & 46.1 \\
\hline
\end{tabular}




\begin{tabular}{|c|c|c|c|}
\hline Month & Year & $\begin{array}{c}\text { Average } \\
\text { Max Temp } \\
\left({ }^{\circ} \mathrm{F}\right)\end{array}$ & $\begin{array}{c}\text { Average Min } \\
\text { Temp }\left({ }^{\circ} \mathrm{F}\right)\end{array}$ \\
\hline December & 1987 & 42.4 & 16.5 \\
\hline January & 1988 & 39.7 & 11.7 \\
\hline February & 1988 & 51.1 & 23.2 \\
\hline March & 1988 & 55.1 & 25.2 \\
\hline April & 1988 & 64.7 & 35.4 \\
\hline May & 1988 & 73.1 & 42.9 \\
\hline June & 1988 & 83.6 & 53.5 \\
\hline July & 1988 & 84.7 & 55.8 \\
\hline August & 1988 & 80.2 & 56.2 \\
\hline September & 1988 & 74.9 & 44.7 \\
\hline October & 1988 & 70.4 & 39.4 \\
\hline November & 1988 & 54.4 & 26.7 \\
\hline December & 1988 & 44.9 & 16.5 \\
\hline January & 1989 & 40.2 & 12.9 \\
\hline February & 1989 & 47.5 & 21.1 \\
\hline March & 1989 & 61.6 & 29.9 \\
\hline April & 1989 & 70.3 & 38.0 \\
\hline May & 1989 & 77.3 & 44.8 \\
\hline June & 1989 & 82.2 & 53.3 \\
\hline July & 1989 & 85.8 & 56.8 \\
\hline August & 1989 & 82.6 & 54.4 \\
\hline September & 1989 & 79.1 & 48.4 \\
\hline October & 1989 & 66.1 & 34.6 \\
\hline November & 1989 & 56.7 & 23.9 \\
\hline December & 1989 & 46.5 & 16.8 \\
\hline January & 1990 & 43.3 & 16.3 \\
\hline February & 1990 & 45.8 & 21.3 \\
\hline March & 1990 & 55.5 & 29.5 \\
\hline April & 1990 & 64.7 & 38.1 \\
\hline May & 1990 & 72.2 & 44.4 \\
\hline June & 1990 & 89.3 & 55.2 \\
\hline July & 1990 & 83.4 & 55.9 \\
\hline August & 1990 & 83.6 & 54.5 \\
\hline September & 1990 & 79.7 & 52.2 \\
\hline October & 1990 & 70.5 & 37.6 \\
\hline November & 1990 & 54.8 & 27.8 \\
\hline December & 1990 & 41.1 & 14.0 \\
\hline January & 1991 & 41.7 & 16.1 \\
\hline February & 1991 & 54.0 & 24.6 \\
\hline March & 1991 & 53.6 & 29.4 \\
\hline April & 1991 & 65.6 & 34.4 \\
\hline May & 1991 & 74.6 & 42.8 \\
\hline June & 1991 & 81.8 & 50.9 \\
\hline July & 1991 & 84.6 & 55.9 \\
\hline August & 1991 & 82.6 & 55.7 \\
\hline September & 1991 & 75.0 & 48.2 \\
\hline October & 1991 & 71.3 & 38.2 \\
\hline November & 1991 & 50.4 & 27.7 \\
\hline
\end{tabular}

\begin{tabular}{|l|r|r|r|}
\hline \multicolumn{1}{|c|}{ Month } & Year & $\begin{array}{c}\text { Average } \\
\text { Max Temp } \\
\text { ('F) }\end{array}$ & $\begin{array}{c}\text { Average Min } \\
\left.\text { Temp ( }{ }^{\circ} \mathbf{F}\right)\end{array}$ \\
\hline December & 1991 & 43.0 & 19.7 \\
\hline January & 1992 & 41.3 & 14.9 \\
\hline February & 1992 & 48.4 & 25.4 \\
\hline March & 1992 & 55.1 & 28.2 \\
\hline April & 1992 & 67.7 & 34.9 \\
\hline May & 1992 & 70.0 & 41.9 \\
\hline June & 1992 & 79.2 & 47.4 \\
\hline July & 1992 & 82.3 & 52.0 \\
\hline August & 1992 & 81.7 & 50.5 \\
\hline September & 1992 & 78.1 & 44.8 \\
\hline October & 1992 & 68.9 & 35.8 \\
\hline November & 1992 & 44.1 & 18.6 \\
\hline December & 1992 & 34.0 & 9.8 \\
\hline January & 1993 & 40.0 & 18.9 \\
\hline February & 1993 & 43.5 & 22.9 \\
\hline March & 1993 & 54.6 & 26.1 \\
\hline April & 1993 & 63.6 & 33.5 \\
\hline May & 1993 & 71.0 & 39.8 \\
\hline June & 1993 & 82.6 & 47.5 \\
\hline July & 1993 & 87.0 & 54.5 \\
\hline August & 1993 & 78.9 & 53.5 \\
\hline September & 1993 & 75.2 & 42.1 \\
\hline October & 1993 & 63.2 & 30.8 \\
\hline November & 1993 & 47.9 & 19.5 \\
\hline December & 1993 & 43.2 & 13.9 \\
\hline January & 1994 & 45.1 & 12.8 \\
\hline February & 1994 & 45.6 & 17.2 \\
\hline March & 1994 & 55.2 & 25.9 \\
\hline April & 1994 & 62.1 & 32.3 \\
\hline May & 1994 & 71.7 & 41.2 \\
\hline June & 1994 & 88.1 & 51.8 \\
\hline July & 1994 & 86.8 & 55.1 \\
\hline August & 1994 & 84.2 & 54.3 \\
\hline September & 1994 & 77.2 & 45.3 \\
\hline October & 1994 & 62.3 & 32.1 \\
\hline November & 1994 & 48.7 & 22.7 \\
\hline December & 1994 & 45.3 & 18.6 \\
\hline January & 1995 & 40.3 & 17.4 \\
\hline February & 1995 & 53.7 & 25.5 \\
\hline March & 1995 & 55.2 & 26.3 \\
\hline April & 1995 & 59.5 & 30.7 \\
\hline May & 1995 & 68.3 & 39.1 \\
\hline June & 1995 & 78.8 & 46.6 \\
\hline Suly & 1995 & 86.3 & 52.5 \\
\hline Novtember & 1995 & 74.8 & 46.0 \\
\hline
\end{tabular}




\begin{tabular}{|c|c|c|c|}
\hline Month & Year & $\begin{array}{c}\text { Average } \\
\text { Max Temp } \\
\left({ }^{\circ} \mathrm{F}\right)\end{array}$ & $\begin{array}{c}\text { Average Min } \\
\text { Temp }\left({ }^{\circ} \mathrm{F}\right)\end{array}$ \\
\hline December & 1995 & 46.8 & 18.3 \\
\hline January & 1996 & 43.1 & 15.3 \\
\hline February & 1996 & 51.5 & 23.5 \\
\hline March & 1996 & 55.2 & 23.3 \\
\hline April & 1996 & 66.3 & 31.2 \\
\hline May & 1996 & 81.4 & 44.4 \\
\hline June & 1996 & 84.3 & 51.9 \\
\hline July & 1996 & 83.1 & 55.3 \\
\hline August & 1996 & 82.7 & 53.6 \\
\hline September & 1996 & 72.3 & 43.0 \\
\hline October & 1996 & 60.6 & 33.3 \\
\hline November & 1996 & 52.3 & 24.2 \\
\hline December & 1996 & 45.1 & 16.4 \\
\hline January & 1997 & 37.8 & 13.5 \\
\hline February & 1997 & 44.2 & 20.8 \\
\hline March & 1997 & 61.0 & 25.5 \\
\hline April & 1997 & 58.8 & 29.3 \\
\hline May & 1997 & 72.4 & 41.2 \\
\hline June & 1997 & 81.2 & 48.5 \\
\hline July & 1997 & 85.3 & 52.7 \\
\hline August & 1997 & 82.0 & 53.1 \\
\hline September & 1997 & 78.5 & 49.2 \\
\hline October & 1997 & 65.4 & 32.1 \\
\hline November & 1997 & 49.2 & 22.1 \\
\hline December & 1997 & 37.2 & 12.1 \\
\hline January & 1998 & 45.1 & 17.6 \\
\hline February & 1998 & 45.1 & 20.2 \\
\hline March & 1998 & 53.8 & 25.2 \\
\hline April & 1998 & 59.6 & 28.9 \\
\hline May & 1998 & 76.5 & 38.7 \\
\hline June & 1998 & 84.1 & 46.8 \\
\hline July & 1998 & 84.3 & 54.9 \\
\hline August & 1998 & 83.7 & 53.1 \\
\hline September & 1998 & 82.3 & 49.3 \\
\hline October & 1998 & 62.7 & 35.4 \\
\hline November & 1998 & 54.4 & 26.3 \\
\hline December & 1998 & 46.5 & 16.3 \\
\hline January & 1999 & 49.0 & 18.7 \\
\hline February & 1999 & 54.3 & 19.8 \\
\hline March & 1999 & 57.9 & 26.9 \\
\hline April & 1999 & 60.7 & 29.8 \\
\hline May & 1999 & 69.9 & 39.0 \\
\hline June & 1999 & 80.6 & 46.1 \\
\hline July & 1999 & 83.5 & 55.2 \\
\hline August & 1999 & 80.7 & 52.4 \\
\hline September & 1999 & 75.7 & 43.8 \\
\hline October & 1999 & 69.2 & 32.5 \\
\hline November & 1999 & 60.9 & 22.3 \\
\hline
\end{tabular}

\begin{tabular}{|l|r|r|r|}
\hline \multicolumn{1}{|c|}{ Month } & Year & $\begin{array}{c}\text { Average } \\
\text { Max Temp } \\
\text { ('F) }\end{array}$ & $\begin{array}{c}\text { Average Min } \\
\left.\text { Temp ( }{ }^{\circ} \mathbf{F}\right)\end{array}$ \\
\hline December & 1999 & 43.2 & 12.6 \\
\hline January & 2000 & 47.7 & 18.1 \\
\hline February & 2000 & 53.3 & 21.9 \\
\hline March & 2000 & 55.8 & 26.0 \\
\hline April & 2000 & 67.4 & 34.3 \\
\hline May & 2000 & 81.0 & 42.3 \\
\hline June & 2000 & 84.6 & 50.5 \\
\hline July & 2000 & 88.5 & 53.6 \\
\hline August & 2000 & 85.5 & 53.8 \\
\hline September & 2000 & 81.4 & 46.7 \\
\hline October & 2000 & 60.9 & 35.9 \\
\hline November & 2000 & 42.9 & 19.5 \\
\hline December & 2000 & 42.4 & 17.0 \\
\hline January & 2001 & 38.5 & 11.9 \\
\hline February & 2001 & 46.9 & 20.4 \\
\hline March & 2001 & 54.9 & 26.6 \\
\hline April & 2001 & 65.5 & 33.4 \\
\hline May & 2001 & 77.0 & 44.1 \\
\hline June & 2001 & 86.8 & 49.1 \\
\hline July & 2001 & 88.5 & 55.9 \\
\hline August & 2001 & 83.3 & 51.9 \\
\hline September & 2001 & 81.8 & 45.3 \\
\hline October & 2001 & 70.0 & 34.1 \\
\hline November & 2001 & 55.0 & 26.3 \\
\hline December & 2001 & 43.1 & 12.5 \\
\hline January & 2002 & 43.5 & 14.5 \\
\hline February & 2002 & 47.5 & 14.5 \\
\hline March & 2002 & 57.5 & 20.5 \\
\hline April & 2002 & 71.8 & 35.2 \\
\hline May & 2002 & 77.8 & 41.1 \\
\hline June & 2002 & 89.5 & 52.6 \\
\hline July & 2002 & 88.6 & 55.7 \\
\hline August & 2002 & 87.9 & 52.7 \\
\hline September & 2002 & 75.7 & 47.1 \\
\hline October & 2002 & 63.1 & 34.6 \\
\hline November & 2002 & 50.2 & 23.7 \\
\hline December & 2002 & 40.6 & 15.7 \\
\hline January & 2003 & 51.9 & 20.4 \\
\hline February & 2003 & 46.5 & 21.2 \\
\hline March & 2003 & 55.7 & 25.5 \\
\hline April & 2003 & 65.7 & 31.9 \\
\hline May & 2003 & 77.0 & 40.9 \\
\hline June & 2003 & 84.0 & 49.1 \\
\hline Suly & 2003 & 85.3 & 57.7 \\
\hline Novtember & 2003 & 79.4 & 45.6 \\
\hline
\end{tabular}




\begin{tabular}{|l|r|r|r|}
\hline \multicolumn{1}{|c|}{ Month } & Year & $\begin{array}{c}\text { Average } \\
\text { Max Temp } \\
\text { ('F) }\end{array}$ & $\begin{array}{c}\text { Average Min } \\
\left.\text { Temp ( }{ }^{\circ} \mathbf{F}\right)\end{array}$ \\
\hline December & 2003 & 44.0 & 16.0 \\
\hline January & 2004 & 43.8 & 15.9 \\
\hline February & 2004 & 41.1 & 14.5 \\
\hline March & 2004 & 61.7 & 30.9 \\
\hline April & 2004 & 60.7 & 33.2 \\
\hline May & 2004 & 77.1 & 41.7 \\
\hline June & 2004 & 84.9 & 49.0 \\
\hline July & 2004 & 86.7 & 52.2 \\
\hline August & 2004 & 81.8 & 52.4 \\
\hline September & 2004 & 77.0 & 44.4 \\
\hline October & 2004 & 62.6 & 35.3 \\
\hline November & 2004 & 48.6 & 25.6 \\
\hline December & 2004 & 43.0 & 15.2 \\
\hline January & 2005 & 46.7 & 25.0 \\
\hline February & 2005 & 46.1 & 26.0 \\
\hline March & 2005 & 51.2 & 25.7 \\
\hline April & 2005 & 64.1 & 32.2 \\
\hline May & 2005 & 74.2 & 41.9 \\
\hline June & 2005 & 84.4 & 47.7 \\
\hline July & 2005 & 91.4 & 55.4 \\
\hline August & 2005 & 82.6 & 52.4 \\
\hline September & 2005 & 79.2 & 47.5 \\
\hline October & 2005 & 63.8 & 36.0 \\
\hline November & 2005 & 56.8 & 23.5 \\
\hline December & 2005 & 46.4 & 15.0 \\
\hline January & 2006 & 48.1 & 15.8 \\
\hline February & 2006 & 53.0 & 16.7 \\
\hline March & 2006 & 55.7 & 26.4 \\
\hline April & 2006 & 69.9 & 34.1 \\
\hline May & 2006 & 79.3 & 43.0 \\
\hline June & 2006 & 87.5 & 51.7 \\
\hline July & 2006 & 86.3 & 56.2 \\
\hline August & 2006 & 79.3 & 55.4 \\
\hline September & 2006 & 72.0 & 42.4 \\
\hline October & 2006 & 64.0 & 34.6 \\
\hline November & 2006 & 56.3 & 23.8 \\
\hline December & 2006 & 40.8 & 15.1 \\
\hline January & 2007 & 36.0 & 12.3 \\
\hline February & 2007 & 46.8 & 19.7 \\
\hline March & 2007 & 61.0 & 27.3 \\
\hline April & 2007 & 64.1 & 32.7 \\
\hline May & 2007 & 71.9 & 41.4 \\
\hline June & 2007 & 84.4 & 49.1 \\
\hline July & 2007 & 56.1 \\
\hline August & & & \\
\hline September & 2007 & 78.6 & 34.9 \\
\hline October & 2007 & \\
\hline November & & \\
\hline
\end{tabular}

\begin{tabular}{|l|r|r|r|}
\hline \multicolumn{1}{|c|}{ Month } & Year & $\begin{array}{c}\text { Average } \\
\text { Max Temp } \\
\text { ('F) }\end{array}$ & $\begin{array}{c}\text { Average Min } \\
\left.\text { Temp ( }{ }^{\circ} \mathbf{F}\right)\end{array}$ \\
\hline December & 2007 & 39.2 & 17.2 \\
\hline January & 2008 & 36.4 & 11.4 \\
\hline February & 2008 & 46.4 & 21.2 \\
\hline March & 2008 & 56.0 & 25.1 \\
\hline April & 2008 & 64.2 & 30.5 \\
\hline May & 2008 & 71.9 & 39.9 \\
\hline June & 2008 & 85.9 & 49.2 \\
\hline July & 2008 & 84.8 & 54.3 \\
\hline August & 2008 & 83.1 & 54.2 \\
\hline September & 2008 & 77.9 & 45.3 \\
\hline October & 2008 & 66.2 & 34.1 \\
\hline November & 2008 & 54.6 & 23.9 \\
\hline December & 2008 & 40.8 & 17.8 \\
\hline January & 2009 & 44.6 & 16.5 \\
\hline February & 2009 & 52.1 & 21.6 \\
\hline March & 2009 & 56.6 & 27.9 \\
\hline April & 2009 & 62.9 & 32.3 \\
\hline May & 2009 & 75.8 & 45.1 \\
\hline June & 2009 & 79.1 & 48.5 \\
\hline July & 2009 & 87.5 & 55.6 \\
\hline August & 2009 & 85.7 & 51.6 \\
\hline September & 2009 & 75.2 & 44.6 \\
\hline October & 2009 & 61.3 & 32.8 \\
\hline November & 2009 & 56.1 & 24.1 \\
\hline December & 2009 & 35.5 & 10.8 \\
\hline January & 2010 & 39.9 & 14.6 \\
\hline February & 2010 & 41.2 & 19.3 \\
\hline March & 2010 & 53.3 & 25.3 \\
\hline April & 2010 & 64.0 & 32.7 \\
\hline May & 2010 & 73.5 & 39.2 \\
\hline June & 2010 & 87.8 & 51.3 \\
\hline July & 2010 & 85.9 & 57.0 \\
\hline August & 2010 & 84.0 & 54.0 \\
\hline September & 2010 & 82.5 & 48.2 \\
\hline October & 2010 & 68.0 & 36.6 \\
\hline November & 2010 & 52.1 & 20.6 \\
\hline December & 2010 & 46.6 & 21.8 \\
\hline January & 2011 & 42.3 & 12.9 \\
\hline February & 2011 & 44.5 & 14.2 \\
\hline March & 2011 & 62.1 & 27.7 \\
\hline April & 2011 & 66.8 & 33.5 \\
\hline May & 2011 & 72.2 & 38.1 \\
\hline June & 2011 & 88.7 & 53.6 \\
\hline Sugty & 2011 & 75.5 & 57.8 \\
\hline November & 2011 & 52.4 & 23.7 \\
\hline
\end{tabular}




\begin{tabular}{|c|c|c|c|}
\hline Month & Year & $\begin{array}{c}\text { Average } \\
\text { Max Temp } \\
\text { (') }\end{array}$ & $\begin{array}{c}\text { Average Min } \\
\left.\text { Temp ( }{ }^{\circ} \mathrm{F}\right)\end{array}$ \\
\hline December & 2011 & 37.5 & 13.6 \\
\hline January & 2012 & 46.7 & 19.9 \\
\hline February & 2012 & 47.2 & 21.3 \\
\hline March & 2012 & 61.5 & 27.1 \\
\hline April & 2012 & 69.2 & 37.4 \\
\hline May & 2012 & 77.5 & 43.9 \\
\hline June & 2012 & 90.9 & 54.3 \\
\hline July & 2012 & 88.2 & 56.0 \\
\hline August & 2012 & 87.1 & 55.4 \\
\hline September & 2012 & 79.5 & 46.7 \\
\hline October & 2012 & 70.9 & 34.6 \\
\hline November & 2012 & 58.2 & 22.7 \\
\hline December & 2012 & 42.4 & 13.7 \\
\hline January & 2013 & 38.8 & 8.0 \\
\hline February & 2013 & 46.0 & 16.7 \\
\hline March & 2013 & 59.7 & 26.1 \\
\hline April & 2013 & 66.3 & 32.9 \\
\hline May & 2013 & 75.2 & 42.2 \\
\hline June & 2013 & 89.5 & 53.9 \\
\hline July & 2013 & 84.5 & 56.6 \\
\hline August & 2013 & 84.3 & 55.2 \\
\hline September & 2013 & 76.1 & 49.2 \\
\hline October & 2013 & 63.4 & 32.8 \\
\hline November & 2013 & 49.3 & 24.3 \\
\hline December & 2013 & 41.5 & 15.4 \\
\hline January & 2014 & 46.9 & 16.4 \\
\hline February & 2014 & 53.0 & 23.8 \\
\hline March & 2014 & 57.5 & 27.8 \\
\hline April & 2014 & 64.3 & 31.7 \\
\hline May & 2014 & 72.9 & 40.5 \\
\hline June & 2014 & 86.5 & 51.9 \\
\hline July & 2014 & 84.0 & 56.3 \\
\hline August & 2014 & 81.6 & 52.1 \\
\hline September & 2014 & 80.6 & 50.5 \\
\hline October & 2014 & 70.1 & 37.5 \\
\hline November & 2014 & 52.9 & 23.0 \\
\hline December & 2014 & 43.7 & 19.4 \\
\hline January & 2015 & 43.6 & 19.0 \\
\hline February & 2015 & 50.2 & 22.1 \\
\hline March & 2015 & 62.1 & 30.3 \\
\hline April & 2015 & 65.1 & 34.8 \\
\hline May & 2015 & 68.0 & 40.3 \\
\hline June & 2015 & 84.6 & 54.7 \\
\hline July & 2015 & 81.9 & 56.7 \\
\hline August & 2015 & 84.3 & 56.3 \\
\hline September & 2015 & 81.5 & 52.7 \\
\hline October & 2015 & 66.2 & 42.4 \\
\hline November & 2015 & 51.4 & 26.5 \\
\hline
\end{tabular}

\begin{tabular}{|l|r|r|r|}
\hline \multicolumn{1}{|c|}{ Month } & Year & \multicolumn{1}{c|}{$\begin{array}{c}\text { Average } \\
\text { Max Temp } \\
\left({ }^{\circ} \mathbf{F}\right)\end{array}$} & $\begin{array}{c}\text { Average Min } \\
\left.\text { Temp ( }{ }^{\circ} \mathbf{F}\right)\end{array}$ \\
\hline December & 2015 & 41.6 & 21.4 \\
\hline January & 2016 & 41.7 & 18.7 \\
\hline February & 2016 & 52.7 & 24.0 \\
\hline March & 2016 & 61.0 & 29.1 \\
\hline April & 2016 & 63.4 & 34.3 \\
\hline May & 2016 & 71.8 & 40.3 \\
\hline June & 2016 & 89.7 & 53.4 \\
\hline
\end{tabular}




\section{White Rock Precipitation}

Data is for tower wrarc. This file was obtained from the LANL Weather Machine http://weather.lanl.gov. Request made on Tuesday, July 19 09:22:13 2016 MST.

\begin{tabular}{|r|l|r|r|}
\hline Day & Month & Year & $\begin{array}{r}\text { Total Precip } \\
\text { (inches) }\end{array}$ \\
\hline 31 & October & 1964 & 0.06 \\
\hline 30 & November & 1964 & 0.52 \\
\hline 31 & December & 1964 & 0.56 \\
\hline 31 & January & 1965 & 1.04 \\
\hline 28 & February & 1965 & 0.65 \\
\hline 31 & March & 1965 & 0.93 \\
\hline 30 & April & 1965 & 1.2 \\
\hline 31 & May & 1965 & 1.37 \\
\hline 30 & June & 1965 & 2.28 \\
\hline 31 & July & 1965 & 1.54 \\
\hline 31 & August & 1965 & 3 \\
\hline 30 & September & 1965 & 2.42 \\
\hline 31 & October & 1965 & 1.06 \\
\hline 30 & November & 1965 & 0.62 \\
\hline 31 & December & 1965 & 2.62 \\
\hline 31 & January & 1966 & 0.34 \\
\hline 28 & February & 1966 & 0.94 \\
\hline 31 & March & 1966 & 0.09 \\
\hline 30 & April & 1966 & 0 \\
\hline 31 & May & 1966 & 0 \\
\hline 30 & June & 1966 & 2.07 \\
\hline 31 & July & 1966 & 1.79 \\
\hline 31 & August & 1966 & 3.19 \\
\hline 30 & September & 1966 & 0.9 \\
\hline 31 & October & 1966 & 0.08 \\
\hline 30 & November & 1966 & 0.4 \\
\hline 31 & December & 1966 & 0.46 \\
\hline 31 & January & 1967 & 0.05 \\
\hline 28 & February & 1967 & 0.43 \\
\hline 31 & March & 1967 & 0.23 \\
\hline 30 & April & 1967 & 0 \\
\hline 31 & May & 1967 & 0.44 \\
\hline 30 & June & 1967 & 1.45 \\
\hline 31 & July & 1967 & 2.27 \\
\hline 31 & August & 1967 & 4.88 \\
\hline 30 & September & 1967 & 1.75 \\
\hline 31 & October & 1967 & 0.14 \\
\hline & & & \\
\hline
\end{tabular}

\begin{tabular}{|r|l|r|r|}
\hline Day & Month & \multicolumn{1}{|c|}{ Year } & $\begin{array}{c}\text { Total Precip } \\
\text { (inches) }\end{array}$ \\
\hline 30 & November & 1967 & 0.25 \\
\hline 31 & December & 1967 & 1.63 \\
\hline 31 & January & 1968 & 0.03 \\
\hline 29 & February & 1968 & 1.04 \\
\hline 31 & March & 1968 & 0.71 \\
\hline 30 & April & 1968 & 0.44 \\
\hline 31 & May & 1968 & 1.4 \\
\hline 30 & June & 1968 & 0.52 \\
\hline 31 & July & 1968 & 4.51 \\
\hline 31 & August & 1968 & 3.89 \\
\hline 30 & September & 1968 & 0.48 \\
\hline 31 & October & 1968 & 0.3 \\
\hline 30 & November & 1968 & 0.41 \\
\hline 31 & December & 1968 & 0.47 \\
\hline 31 & January & 1969 & 0.44 \\
\hline 28 & February & 1969 & 0.48 \\
\hline 31 & March & 1969 & 0.72 \\
\hline 30 & April & 1969 & 1.98 \\
\hline 31 & May & 1969 & 1.47 \\
\hline 30 & June & 1969 & 2.22 \\
\hline 31 & July & 1969 & 2.05 \\
\hline 31 & August & 1969 & 4.26 \\
\hline 30 & September & 1969 & 1.38 \\
\hline 31 & October & 1969 & 2.84 \\
\hline 30 & November & 1969 & 0.08 \\
\hline 31 & December & 1969 & 1.07 \\
\hline 31 & January & 1970 & 0 \\
\hline 28 & February & 1970 & 0.08 \\
\hline 31 & March & 1970 & 1.21 \\
\hline 30 & April & 1970 & 0.1 \\
\hline 31 & May & 1970 & 0.17 \\
\hline 30 & June & 1970 & 0.82 \\
\hline 31 & July & 1970 & 3.01 \\
\hline 31 & August & 1970 & 2.45 \\
\hline 30 & September & 1970 & 1.55 \\
\hline 31 & October & 1970 & 0.28 \\
\hline 30 & November & 1970 & 0.08 \\
\hline & & & \\
\hline
\end{tabular}




\begin{tabular}{|c|c|c|c|}
\hline Day & Month & Year & $\begin{array}{l}\text { Total Precip } \\
\text { (inches) }\end{array}$ \\
\hline 31 & December & 1970 & 0 \\
\hline 31 & January & 1971 & 1.33 \\
\hline 28 & February & 1971 & 0.45 \\
\hline 31 & March & 1971 & 0.25 \\
\hline 30 & April & 1971 & 0.55 \\
\hline 31 & May & 1971 & 0.7 \\
\hline 30 & June & 1971 & 0.3 \\
\hline 31 & July & 1971 & 3.93 \\
\hline 31 & August & 1971 & 1.74 \\
\hline 30 & September & 1971 & 1.88 \\
\hline 31 & October & 1971 & 1.94 \\
\hline 30 & November & 1971 & 0.95 \\
\hline 31 & December & 1971 & 1.77 \\
\hline 31 & January & 1972 & 0.1 \\
\hline 29 & February & 1972 & 0.07 \\
\hline 31 & March & 1972 & 0.07 \\
\hline 30 & April & 1972 & 0 \\
\hline 31 & May & 1972 & 1.3 \\
\hline 30 & June & 1972 & 1.03 \\
\hline 31 & July & 1972 & 1.34 \\
\hline 31 & August & 1972 & 3.44 \\
\hline 30 & September & 1972 & 3.06 \\
\hline 31 & October & 1972 & 2.7 \\
\hline 30 & November & 1972 & 1.45 \\
\hline 31 & December & 1972 & 0.9 \\
\hline 31 & January & 1973 & 0.37 \\
\hline 28 & February & 1973 & 0.6 \\
\hline 31 & March & 1973 & 2.06 \\
\hline 30 & April & 1973 & 0.38 \\
\hline 31 & May & 1973 & 0.95 \\
\hline 30 & June & 1973 & 0.55 \\
\hline 31 & July & 1973 & 2.88 \\
\hline 31 & August & 1973 & 1.43 \\
\hline 30 & September & 1973 & 1.6 \\
\hline 31 & October & 1973 & 0.33 \\
\hline 30 & November & 1973 & 0.31 \\
\hline 31 & December & 1973 & 0.19 \\
\hline 31 & January & 1974 & 1.01 \\
\hline 28 & February & 1974 & 0.45 \\
\hline 31 & March & 1974 & 0.9 \\
\hline 30 & April & 1974 & 0.26 \\
\hline
\end{tabular}

\begin{tabular}{|c|c|c|c|}
\hline Day & Month & Year & $\begin{array}{c}\text { Total Precip } \\
\text { (inches) }\end{array}$ \\
\hline 31 & May & 1974 & 0.01 \\
\hline 30 & June & 1974 & 0.66 \\
\hline 31 & July & 1974 & 2.19 \\
\hline 31 & August & 1974 & 2.21 \\
\hline 30 & September & 1974 & 0.85 \\
\hline 31 & October & 1974 & 2.65 \\
\hline 30 & November & 1974 & 0.33 \\
\hline 31 & December & 1974 & 0.61 \\
\hline 31 & January & 1975 & 0.95 \\
\hline 28 & February & 1975 & 1.42 \\
\hline 31 & March & 1975 & 0.93 \\
\hline 30 & April & 1975 & 0.93 \\
\hline 31 & May & 1975 & 0.1 \\
\hline 30 & June & 1975 & 0.84 \\
\hline 31 & July & 1975 & 2.58 \\
\hline 31 & August & 1975 & 0.85 \\
\hline 30 & September & 1975 & 2.8 \\
\hline 31 & October & 1975 & 0.07 \\
\hline 30 & November & 1975 & 0.59 \\
\hline 31 & December & 1975 & 0.24 \\
\hline 31 & January & 1976 & 0 \\
\hline 29 & February & 1976 & 1.01 \\
\hline 31 & March & 1976 & 0.58 \\
\hline 30 & April & 1976 & 0.32 \\
\hline 31 & May & 1976 & 0.57 \\
\hline 30 & June & 1976 & 0.06 \\
\hline 31 & July & 1976 & 3.65 \\
\hline 31 & August & 1976 & 2.77 \\
\hline 30 & September & 1976 & 1.28 \\
\hline 31 & October & 1976 & 0 \\
\hline 30 & November & 1976 & 0.72 \\
\hline 31 & December & 1976 & 0.1 \\
\hline 31 & January & 1977 & 0.76 \\
\hline 28 & February & 1977 & 0.06 \\
\hline 31 & March & 1977 & 0.17 \\
\hline 30 & April & 1977 & 1.13 \\
\hline 31 & May & 1977 & 0.44 \\
\hline 30 & June & 1977 & 0.96 \\
\hline 31 & July & 1977 & 1.11 \\
\hline 31 & August & 1977 & 1.52 \\
\hline 30 & September & 1977 & 0.3 \\
\hline
\end{tabular}




\begin{tabular}{|c|c|c|c|}
\hline Day & Month & Year & $\begin{array}{c}\text { Total Precip } \\
\text { (inches) }\end{array}$ \\
\hline 31 & October & 1977 & 0.05 \\
\hline 30 & November & 1977 & 1.19 \\
\hline 31 & December & 1977 & 0.13 \\
\hline 31 & January & 1978 & 0.79 \\
\hline 28 & February & 1978 & 0.14 \\
\hline 31 & March & 1978 & 1.01 \\
\hline 30 & April & 1978 & 0.05 \\
\hline 31 & May & 1978 & 1.21 \\
\hline 30 & June & 1978 & 0.7 \\
\hline 31 & July & 1978 & 1.25 \\
\hline 31 & August & 1978 & 0.75 \\
\hline 30 & September & 1978 & 0.58 \\
\hline 31 & October & 1978 & 0.6 \\
\hline 30 & November & 1978 & 3.05 \\
\hline 31 & December & 1978 & 1.09 \\
\hline 31 & January & 1979 & 0.8 \\
\hline 28 & February & 1979 & 0.05 \\
\hline 31 & March & 1979 & 0.32 \\
\hline 30 & April & 1979 & 0.09 \\
\hline 31 & May & 1979 & 1.45 \\
\hline 30 & June & 1979 & 1.24 \\
\hline 31 & July & 1979 & 0.24 \\
\hline 31 & August & 1979 & 1.05 \\
\hline 30 & September & 1979 & 0.44 \\
\hline 31 & October & 1979 & 0.46 \\
\hline 30 & November & 1979 & 0 \\
\hline 31 & December & 1979 & 0 \\
\hline 31 & January & 1980 & 0 \\
\hline 29 & February & 1980 & 0 \\
\hline 31 & March & 1980 & 0 \\
\hline 30 & April & 1980 & 0 \\
\hline 31 & May & 1980 & 0.64 \\
\hline 30 & June & 1980 & 0 \\
\hline 31 & July & 1980 & 0.17 \\
\hline 31 & August & 1980 & 0.97 \\
\hline 30 & September & 1980 & 0.52 \\
\hline 31 & October & 1980 & 0.58 \\
\hline 30 & November & 1980 & 0.35 \\
\hline 31 & December & 1980 & 0.18 \\
\hline 31 & January & 1981 & 0.08 \\
\hline 28 & February & 1981 & 0.07 \\
\hline
\end{tabular}

\begin{tabular}{|c|c|c|c|}
\hline Day & Month & Year & $\begin{array}{l}\text { Total Precip } \\
\text { (inches) }\end{array}$ \\
\hline 31 & March & 1981 & 1.7 \\
\hline 30 & April & 1981 & 0.9 \\
\hline 31 & May & 1981 & 0.96 \\
\hline 30 & June & 1981 & 0.55 \\
\hline 31 & July & 1981 & 1.88 \\
\hline 31 & August & 1981 & 1.22 \\
\hline 30 & September & 1981 & 2.06 \\
\hline 31 & October & 1981 & 0.97 \\
\hline 30 & November & 1981 & 0.56 \\
\hline 31 & December & 1981 & 0 \\
\hline 31 & January & 1982 & 0.7 \\
\hline 28 & February & 1982 & 1.37 \\
\hline 31 & March & 1982 & 0.73 \\
\hline 30 & April & 1982 & 0.2 \\
\hline 31 & May & 1982 & 1.12 \\
\hline 30 & June & 1982 & 0.95 \\
\hline 31 & July & 1982 & 2.02 \\
\hline 31 & August & 1982 & 2.43 \\
\hline 30 & September & 1982 & 1.52 \\
\hline 31 & October & 1982 & 0.48 \\
\hline 30 & November & 1982 & 1.5 \\
\hline 31 & December & 1982 & 1.36 \\
\hline 31 & January & 1983 & 0.88 \\
\hline 28 & February & 1983 & 0.62 \\
\hline 31 & March & 1983 & 1.25 \\
\hline 30 & April & 1983 & 0.62 \\
\hline 31 & May & 1983 & 0 \\
\hline 30 & June & 1983 & 0.63 \\
\hline 31 & July & 1983 & 2.49 \\
\hline 31 & August & 1983 & 2.16 \\
\hline 30 & September & 1983 & 0.48 \\
\hline 31 & October & 1983 & 1.01 \\
\hline 30 & November & 1983 & 0.58 \\
\hline 31 & December & 1983 & 0.61 \\
\hline 31 & January & 1984 & 0.41 \\
\hline 29 & February & 1984 & 0.02 \\
\hline 31 & March & 1984 & 1.44 \\
\hline 30 & April & 1984 & 0.23 \\
\hline 31 & May & 1984 & 0.16 \\
\hline 30 & June & 1984 & 0.3 \\
\hline 31 & July & 1984 & 1.51 \\
\hline
\end{tabular}




\begin{tabular}{|c|c|c|c|}
\hline Day & Month & Year & $\begin{array}{c}\text { Total Precip } \\
\text { (inches) }\end{array}$ \\
\hline 31 & August & 1984 & 2.65 \\
\hline 30 & September & 1984 & 0.2 \\
\hline 31 & October & 1984 & 2.41 \\
\hline 30 & November & 1984 & 0.25 \\
\hline 31 & December & 1984 & 2.65 \\
\hline 31 & January & 1985 & 0.53 \\
\hline 28 & February & 1985 & 1.18 \\
\hline 31 & March & 1985 & 3.36 \\
\hline 30 & April & 1985 & 2.8 \\
\hline 31 & May & 1985 & 2.05 \\
\hline 30 & June & 1985 & 0.82 \\
\hline 31 & July & 1985 & 1.08 \\
\hline 31 & August & 1985 & 2.06 \\
\hline 30 & September & 1985 & 1.91 \\
\hline 31 & October & 1985 & 3.12 \\
\hline 30 & November & 1985 & 0.52 \\
\hline 31 & December & 1985 & 0.16 \\
\hline 31 & January & 1986 & 0.01 \\
\hline 28 & February & 1986 & 0.87 \\
\hline 31 & March & 1986 & 0.84 \\
\hline 30 & April & 1986 & 1.21 \\
\hline 31 & May & 1986 & 1.45 \\
\hline 30 & June & 1986 & 3.26 \\
\hline 31 & July & 1986 & 2.7 \\
\hline 31 & August & 1986 & 0.97 \\
\hline 30 & September & 1986 & 2.48 \\
\hline 31 & October & 1986 & 1.95 \\
\hline 30 & November & 1986 & 2.54 \\
\hline 31 & December & 1986 & 0.61 \\
\hline 31 & January & 1987 & 0.94 \\
\hline 28 & February & 1987 & 1.26 \\
\hline 31 & March & 1987 & 0.38 \\
\hline 30 & April & 1987 & 0.49 \\
\hline 31 & May & 1987 & 2.35 \\
\hline 30 & June & 1987 & 0.52 \\
\hline 31 & July & 1987 & 1.28 \\
\hline 31 & August & 1987 & 4.82 \\
\hline 30 & September & 1987 & 0.96 \\
\hline 31 & October & 1987 & 0.49 \\
\hline 30 & November & 1987 & 1.2 \\
\hline 31 & December & 1987 & 1.19 \\
\hline
\end{tabular}

\begin{tabular}{|r|l|r|r|}
\hline Day & Month & Year & $\begin{array}{r}\text { Total Precip } \\
\text { (inches) }\end{array}$ \\
\hline 31 & January & 1988 & 0.86 \\
\hline 29 & February & 1988 & 0.18 \\
\hline 31 & March & 1988 & 0.55 \\
\hline 30 & April & 1988 & 1.25 \\
\hline 31 & May & 1988 & 1.59 \\
\hline 30 & June & 1988 & 0.99 \\
\hline 31 & July & 1988 & 2.15 \\
\hline 31 & August & 1988 & 0 \\
\hline 30 & September & 1988 & 3.47 \\
\hline 31 & October & 1988 & 0.74 \\
\hline 30 & November & 1988 & 0.23 \\
\hline 31 & December & 1988 & 0.18 \\
\hline 31 & January & 1989 & 1.27 \\
\hline 28 & February & 1989 & 0.7 \\
\hline 31 & March & 1989 & 0.68 \\
\hline 30 & April & 1989 & 0.1 \\
\hline 31 & May & 1989 & 1.65 \\
\hline 30 & June & 1989 & 0.55 \\
\hline 31 & July & 1989 & 1.7 \\
\hline 31 & August & 1989 & 1.37 \\
\hline 30 & September & 1989 & 1.59 \\
\hline 31 & October & 1989 & 3.86 \\
\hline 30 & November & 1989 & 0.05 \\
\hline 31 & December & 1989 & 0.55 \\
\hline 31 & January & 1990 & 0.67 \\
\hline 28 & February & 1990 & 0.38 \\
\hline 31 & March & 1990 & 0.54 \\
\hline 30 & April & 1990 & 1.59 \\
\hline 31 & May & 1990 & 0.76 \\
\hline 30 & June & 1990 & 0.92 \\
\hline 31 & July & 1990 & 4.64 \\
\hline 31 & August & 1990 & 0.88 \\
\hline 30 & September & 1990 & 2.28 \\
\hline 31 & October & 1990 & 0.28 \\
\hline 30 & November & 1990 & 1.71 \\
\hline 31 & December & 1990 & 1.91 \\
\hline 31 & January & 1991 & 0.18 \\
\hline 31 & February & 1991 & 0.56 \\
\hline & Aarch & 1991 & 1.17 \\
\hline 3 May & 1991 & 0.02 \\
\hline
\end{tabular}




\begin{tabular}{|c|c|c|c|}
\hline Day & Month & Year & $\begin{array}{c}\text { Total Precip } \\
\text { (inches) }\end{array}$ \\
\hline 30 & June & 1991 & 1.66 \\
\hline 31 & July & 1991 & 4.54 \\
\hline 31 & August & 1991 & 2.53 \\
\hline 30 & September & 1991 & 1.83 \\
\hline 31 & October & 1991 & 0.58 \\
\hline 30 & November & 1991 & 2.2 \\
\hline 31 & December & 1991 & 1.75 \\
\hline 31 & January & 1992 & 0.49 \\
\hline 29 & February & 1992 & 0.47 \\
\hline 31 & March & 1992 & 1.04 \\
\hline 30 & April & 1992 & 0.23 \\
\hline 31 & May & 1992 & 3.41 \\
\hline 30 & June & 1992 & 0.81 \\
\hline 31 & July & 1992 & 1.17 \\
\hline 31 & August & 1992 & 1.66 \\
\hline 30 & September & 1992 & 1.03 \\
\hline 31 & October & 1992 & 0.22 \\
\hline 30 & November & 1992 & 0.96 \\
\hline 31 & December & 1992 & 1.65 \\
\hline 31 & January & 1993 & 2.04 \\
\hline 28 & February & 1993 & 1.28 \\
\hline 31 & March & 1993 & 0.79 \\
\hline 30 & April & 1993 & 0.04 \\
\hline 31 & May & 1993 & 1.05 \\
\hline 30 & June & 1993 & 0.34 \\
\hline 31 & July & 1993 & 1.33 \\
\hline 31 & August & 1993 & 3.91 \\
\hline 30 & September & 1993 & 0.72 \\
\hline 31 & October & 1993 & 0.56 \\
\hline 30 & November & 1993 & 0.93 \\
\hline 31 & December & 1993 & 0.12 \\
\hline 31 & January & 1994 & 0.3 \\
\hline 28 & February & 1994 & 0.31 \\
\hline 31 & March & 1994 & 1.22 \\
\hline 30 & April & 1994 & 0.95 \\
\hline 31 & May & 1994 & 2.04 \\
\hline 30 & June & 1994 & 0.73 \\
\hline 31 & July & 1994 & 2.1 \\
\hline 31 & August & 1994 & 2.36 \\
\hline 30 & September & 1994 & 1.53 \\
\hline 31 & October & 1994 & 2.51 \\
\hline
\end{tabular}

\begin{tabular}{|c|c|c|c|}
\hline Day & Month & Year & $\begin{array}{l}\text { Total Precip } \\
\text { (inches) }\end{array}$ \\
\hline 30 & November & 1994 & 2.13 \\
\hline 31 & December & 1994 & 0.77 \\
\hline 31 & January & 1995 & 0.8 \\
\hline 28 & February & 1995 & 0.49 \\
\hline 31 & March & 1995 & 0.47 \\
\hline 30 & April & 1995 & 1.29 \\
\hline 31 & May & 1995 & 1.61 \\
\hline 30 & June & 1995 & 1.1 \\
\hline 31 & July & 1995 & 0.73 \\
\hline 31 & August & 1995 & 3.21 \\
\hline 30 & September & 1995 & 2.72 \\
\hline 31 & October & 1995 & 0 \\
\hline 30 & November & 1995 & 0.1 \\
\hline 31 & December & 1995 & 0.27 \\
\hline 31 & January & 1996 & 0.8 \\
\hline 29 & February & 1996 & 0.46 \\
\hline 31 & March & 1996 & 0.15 \\
\hline 30 & April & 1996 & 0.07 \\
\hline 31 & May & 1996 & 0 \\
\hline 30 & June & 1996 & 3.32 \\
\hline 31 & July & 1996 & 3.52 \\
\hline 31 & August & 1996 & 1.5 \\
\hline 30 & September & 1996 & 1.36 \\
\hline 31 & October & 1996 & 3.62 \\
\hline 30 & November & 1996 & 0.53 \\
\hline 31 & December & 1996 & 0.01 \\
\hline 31 & January & 1997 & 1.05 \\
\hline 28 & February & 1997 & 1.56 \\
\hline 31 & March & 1997 & 0.17 \\
\hline 30 & April & 1997 & 1.74 \\
\hline 31 & May & 1997 & 0.96 \\
\hline 30 & June & 1997 & 1.72 \\
\hline 31 & July & 1997 & 1.64 \\
\hline 31 & August & 1997 & 3.98 \\
\hline 30 & September & 1997 & 2.06 \\
\hline 31 & October & 1997 & 0.85 \\
\hline 30 & November & 1997 & 0.88 \\
\hline 31 & December & 1997 & 1.17 \\
\hline 31 & January & 1998 & 0.03 \\
\hline 28 & February & 1998 & 0.2 \\
\hline 31 & March & 1998 & 1.46 \\
\hline
\end{tabular}




\begin{tabular}{|r|l|r|r|}
\hline Day & Month & Year & $\begin{array}{r}\text { Total Precip } \\
\text { (inches) }\end{array}$ \\
\hline 30 & April & 1998 & 0.61 \\
\hline 31 & May & 1998 & 0.01 \\
\hline 30 & June & 1998 & 0.45 \\
\hline 31 & July & 1998 & 3.35 \\
\hline 31 & August & 1998 & 1.66 \\
\hline 30 & September & 1998 & 1.25 \\
\hline 31 & October & 1998 & 3.35 \\
\hline 30 & November & 1998 & 0.3 \\
\hline 31 & December & 1998 & 0.02 \\
\hline 31 & January & 1999 & 0.08 \\
\hline 28 & February & 1999 & 0.02 \\
\hline 31 & March & 1999 & 1.11 \\
\hline 30 & April & 1999 & 2.19 \\
\hline 31 & May & 1999 & 1.66 \\
\hline 30 & June & 1999 & 3.75 \\
\hline 31 & July & 1999 & 1.7 \\
\hline 31 & August & 1999 & 4.1 \\
\hline 30 & September & 1999 & 1.45 \\
\hline 31 & October & 1999 & 0.5 \\
\hline 30 & November & 1999 & 0.05 \\
\hline 31 & December & 1999 & 0.24 \\
\hline 31 & January & 2000 & 0.38 \\
\hline 29 & February & 2000 & 0.03 \\
\hline 31 & March & 2000 & 1.2 \\
\hline 30 & April & 2000 & 0.5 \\
\hline 31 & May & 2000 & 0 \\
\hline 30 & June & 2000 & 1.58 \\
\hline 31 & July & 2000 & 1.26 \\
\hline 31 & August & 2000 & 3.3 \\
\hline 30 & September & 2000 & 0.32 \\
\hline 31 & October & 2000 & 3.58 \\
\hline 30 & November & 2000 & 1.63 \\
\hline 31 & December & 2000 & 0.25 \\
\hline 31 & January & 2001 & 1.5 \\
\hline 28 & February & 2001 & 0.69 \\
\hline 30 & Juarch & 2001 & 0.66 \\
\hline & June & 2001 & 0.78 \\
\hline 31 & 2001 & 0.58 \\
\hline 31 & 2001 & 0.61 \\
\hline 31 & & \\
\hline 31 & & \\
\hline
\end{tabular}

\begin{tabular}{|c|c|c|c|}
\hline Day & Month & Year & $\begin{array}{l}\text { Total Precip } \\
\text { (inches) }\end{array}$ \\
\hline 30 & September & 2001 & 0.22 \\
\hline 31 & October & 2001 & 0.27 \\
\hline 30 & November & 2001 & 0.15 \\
\hline 31 & December & 2001 & 0.15 \\
\hline 31 & January & 2002 & 0.58 \\
\hline 28 & February & 2002 & 0.02 \\
\hline 31 & March & 2002 & 0.01 \\
\hline 30 & April & 2002 & 0.25 \\
\hline 31 & May & 2002 & 0 \\
\hline 30 & June & 2002 & 0.52 \\
\hline 31 & July & 2002 & 0.64 \\
\hline 31 & August & 2002 & 1.7 \\
\hline 30 & September & 2002 & 2.46 \\
\hline 31 & October & 2002 & 1.74 \\
\hline 30 & November & 2002 & 0.79 \\
\hline 31 & December & 2002 & 0.66 \\
\hline 31 & January & 2003 & 0 \\
\hline 28 & February & 2003 & 0.84 \\
\hline 31 & March & 2003 & 0.96 \\
\hline 30 & April & 2003 & 0.19 \\
\hline 31 & May & 2003 & 1.6 \\
\hline 30 & June & 2003 & 0.09 \\
\hline 31 & July & 2003 & 0.17 \\
\hline 31 & August & 2003 & 2.28 \\
\hline 30 & September & 2003 & 0.44 \\
\hline 31 & October & 2003 & 1.13 \\
\hline 30 & November & 2003 & 0.64 \\
\hline 31 & December & 2003 & 0.26 \\
\hline 31 & January & 2004 & 0.53 \\
\hline 29 & February & 2004 & 1.17 \\
\hline 31 & March & 2004 & 1.08 \\
\hline 30 & April & 2004 & 3.08 \\
\hline 31 & May & 2004 & 0 \\
\hline 30 & June & 2004 & 0.53 \\
\hline 31 & July & 2004 & 1.46 \\
\hline 31 & August & 2004 & 2.19 \\
\hline 30 & September & 2004 & 1.17 \\
\hline 31 & October & 2004 & 2.76 \\
\hline 30 & November & 2004 & 1.05 \\
\hline 31 & December & 2004 & 0.62 \\
\hline 31 & January & 2005 & 1.67 \\
\hline
\end{tabular}




\begin{tabular}{|c|c|c|c|}
\hline Day & Month & Year & $\begin{array}{c}\text { Total Precip } \\
\text { (inches) }\end{array}$ \\
\hline 28 & February & 2005 & 1.69 \\
\hline 31 & March & 2005 & 1.63 \\
\hline 30 & April & 2005 & 1.28 \\
\hline 31 & May & 2005 & 0.67 \\
\hline 30 & June & 2005 & 0.27 \\
\hline 31 & July & 2005 & 0.86 \\
\hline 31 & August & 2005 & 3.19 \\
\hline 30 & September & 2005 & 3.77 \\
\hline 31 & October & 2005 & 1.59 \\
\hline 30 & November & 2005 & 0.08 \\
\hline 31 & December & 2005 & 0 \\
\hline 31 & January & 2006 & 0.08 \\
\hline 28 & February & 2006 & 0 \\
\hline 31 & March & 2006 & 0.33 \\
\hline 30 & April & 2006 & 0.25 \\
\hline 31 & May & 2006 & 0.18 \\
\hline 30 & June & 2006 & 0.94 \\
\hline 31 & July & 2006 & 2.17 \\
\hline 31 & August & 2006 & 4.58 \\
\hline 30 & September & 2006 & 0.6 \\
\hline 31 & October & 2006 & 1.65 \\
\hline 30 & November & 2006 & 0.42 \\
\hline 31 & December & 2006 & 1.31 \\
\hline 31 & January & 2007 & 0.5 \\
\hline 28 & February & 2007 & 0.52 \\
\hline 31 & March & 2007 & 0.95 \\
\hline 30 & April & 2007 & 0.61 \\
\hline 31 & May & 2007 & 1.53 \\
\hline 30 & June & 2007 & 1.05 \\
\hline 31 & July & 2007 & 2.42 \\
\hline 31 & August & 2007 & 1.15 \\
\hline 30 & September & 2007 & 2.38 \\
\hline 31 & October & 2007 & 0.22 \\
\hline 30 & November & 2007 & 1.42 \\
\hline 31 & December & 2007 & 2.3 \\
\hline 31 & January & 2008 & 1.02 \\
\hline 29 & February & 2008 & 0.91 \\
\hline 31 & March & 2008 & 0.88 \\
\hline 30 & April & 2008 & 0.16 \\
\hline 31 & May & 2008 & 0.84 \\
\hline 30 & June & 2008 & 0.04 \\
\hline
\end{tabular}

\begin{tabular}{|r|l|r|r|}
\hline Day & Month & Year & $\begin{array}{r}\text { Total Precip } \\
\text { (inches) }\end{array}$ \\
\hline 31 & July & 2008 & 1.84 \\
\hline 31 & August & 2008 & 2.01 \\
\hline 30 & September & 2008 & 0.54 \\
\hline 31 & October & 2008 & 1.99 \\
\hline 30 & November & 2008 & 0.39 \\
\hline 31 & December & 2008 & 1.3 \\
\hline 31 & January & 2009 & 0.15 \\
\hline 28 & February & 2009 & 0.02 \\
\hline 31 & March & 2009 & 0.91 \\
\hline 30 & April & 2009 & 0.83 \\
\hline 31 & May & 2009 & 1.05 \\
\hline 30 & June & 2009 & 1.74 \\
\hline 31 & July & 2009 & 2.01 \\
\hline 31 & August & 2009 & 0.95 \\
\hline 30 & September & 2009 & 1.93 \\
\hline 31 & October & 2009 & 1.34 \\
\hline 30 & November & 2009 & 0.39 \\
\hline 31 & December & 2009 & 0.5 \\
\hline 31 & January & 2010 & 1.15 \\
\hline 28 & February & 2010 & 1.16 \\
\hline 31 & March & 2010 & 1.32 \\
\hline 30 & April & 2010 & 0.64 \\
\hline 31 & May & 2010 & 0.25 \\
\hline 30 & June & 2010 & 0.22 \\
\hline 31 & July & 2010 & 3.49 \\
\hline 31 & August & 2010 & 2.88 \\
\hline 30 & September & 2010 & 0.78 \\
\hline 31 & October & 2010 & 0.54 \\
\hline 30 & November & 2010 & 0.05 \\
\hline 31 & December & 2010 & 1.01 \\
\hline 31 & January & 2011 & 0 \\
\hline 28 & February & 2011 & 0.01 \\
\hline 31 & March & 2011 & 0.03 \\
\hline 30 & April & 2011 & 0.23 \\
\hline 31 & May & 2011 & 0.04 \\
\hline 30 & June & 2011 & 0.02 \\
\hline 31 & July & 2011 & 2.53 \\
\hline & Ougust & 2011 & 2.66 \\
\hline 3011 & 2011 & \\
\hline 31 & & \\
\hline
\end{tabular}




\begin{tabular}{|c|c|c|c|}
\hline Day & Month & Year & $\begin{array}{c}\text { Total Precip } \\
\text { (inches) }\end{array}$ \\
\hline 31 & December & 2011 & 1.35 \\
\hline 31 & January & 2012 & 0.07 \\
\hline 29 & February & 2012 & 0.12 \\
\hline 31 & March & 2012 & 0.17 \\
\hline 30 & April & 2012 & 0.74 \\
\hline 31 & May & 2012 & 0.78 \\
\hline 30 & June & 2012 & 0 \\
\hline 31 & July & 2012 & 2.02 \\
\hline 31 & August & 2012 & 1.64 \\
\hline 30 & September & 2012 & 0.6 \\
\hline 31 & October & 2012 & 0.14 \\
\hline 30 & November & 2012 & 0.11 \\
\hline 31 & December & 2012 & 0.53 \\
\hline 31 & January & 2013 & 0.27 \\
\hline 28 & February & 2013 & 0.12 \\
\hline 31 & March & 2013 & 0.15 \\
\hline 30 & April & 2013 & 0.1 \\
\hline 31 & May & 2013 & 0 \\
\hline 30 & June & 2013 & 1.01 \\
\hline 31 & July & 2013 & 2.85 \\
\hline 31 & August & 2013 & 1.86 \\
\hline 30 & September & 2013 & 7.68 \\
\hline 31 & October & 2013 & 0.66 \\
\hline 30 & November & 2013 & 1.67 \\
\hline 31 & December & 2013 & 0.05 \\
\hline 31 & January & 2014 & 0.01 \\
\hline 28 & February & 2014 & 0.07 \\
\hline 31 & March & 2014 & 0.51 \\
\hline 30 & April & 2014 & 0.11 \\
\hline 31 & May & 2014 & 0.98 \\
\hline 30 & June & 2014 & 0.66 \\
\hline 31 & July & 2014 & 3.98 \\
\hline 31 & August & 2014 & 1.17 \\
\hline 30 & September & 2014 & 0.26 \\
\hline 31 & October & 2014 & 0.41 \\
\hline 30 & November & 2014 & 0.45 \\
\hline 31 & December & 2014 & 0.91 \\
\hline 31 & January & 2015 & 1.03 \\
\hline 28 & February & 2015 & 0.72 \\
\hline 31 & March & 2015 & 0.62 \\
\hline 30 & April & 2015 & 0.77 \\
\hline
\end{tabular}

\begin{tabular}{|r|l|r|r|}
\hline Day & \multicolumn{1}{|c|}{ Month } & \multicolumn{1}{c|}{ Year } & $\begin{array}{c}\text { Total Precip } \\
\text { (inches) }\end{array}$ \\
\hline 31 & May & 2015 & 2.92 \\
\hline 30 & June & 2015 & 0.38 \\
\hline 31 & July & 2015 & 3.68 \\
\hline 31 & August & 2015 & 1.32 \\
\hline 30 & September & 2015 & 0.3 \\
\hline 31 & October & 2015 & 2.82 \\
\hline 30 & November & 2015 & 0.78 \\
\hline 31 & December & 2015 & 0.6 \\
\hline
\end{tabular}

